
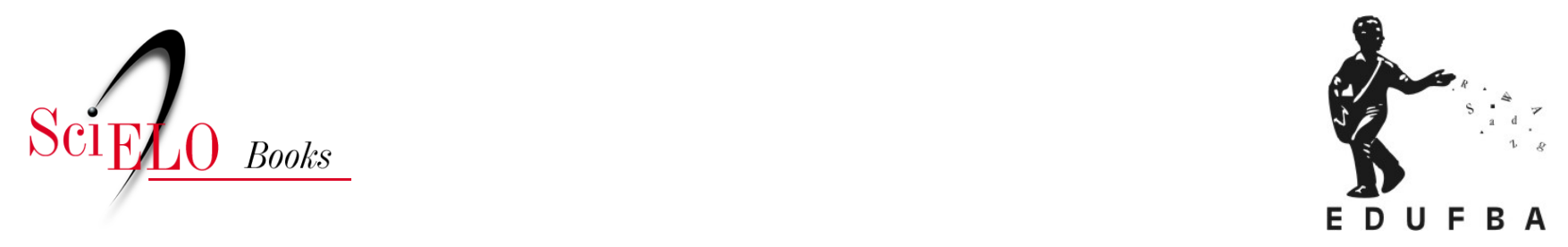

\title{
Front Matter / Elementos Pré-textuais / Páginas Iniciales
}

\author{
Suely Messeder \\ Mary Garcia Castro \\ Laura Moutinho \\ (orgs.)
}

MESSEDER, S., CASTRO, M.G., and MOUTINHO, L., orgs. Enlaçando sexualidades: uma tessitura interdisciplinar no reino das sexualidades e das relações de gênero [online]. Salvador: EDUFBA, 2016, pp. 1-7. ISBN: 978-85-232-1866-9. https://doi.org/10.7476/9788523218669.

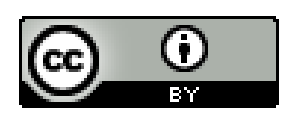

All the contents of this work, except where otherwise noted, is licensed under a Creative Commons Attribution $\underline{4.0 \text { International license. }}$

Todo o conteúdo deste trabalho, exceto quando houver ressalva, é publicado sob a licença Creative Commons Atribição 4.0. 


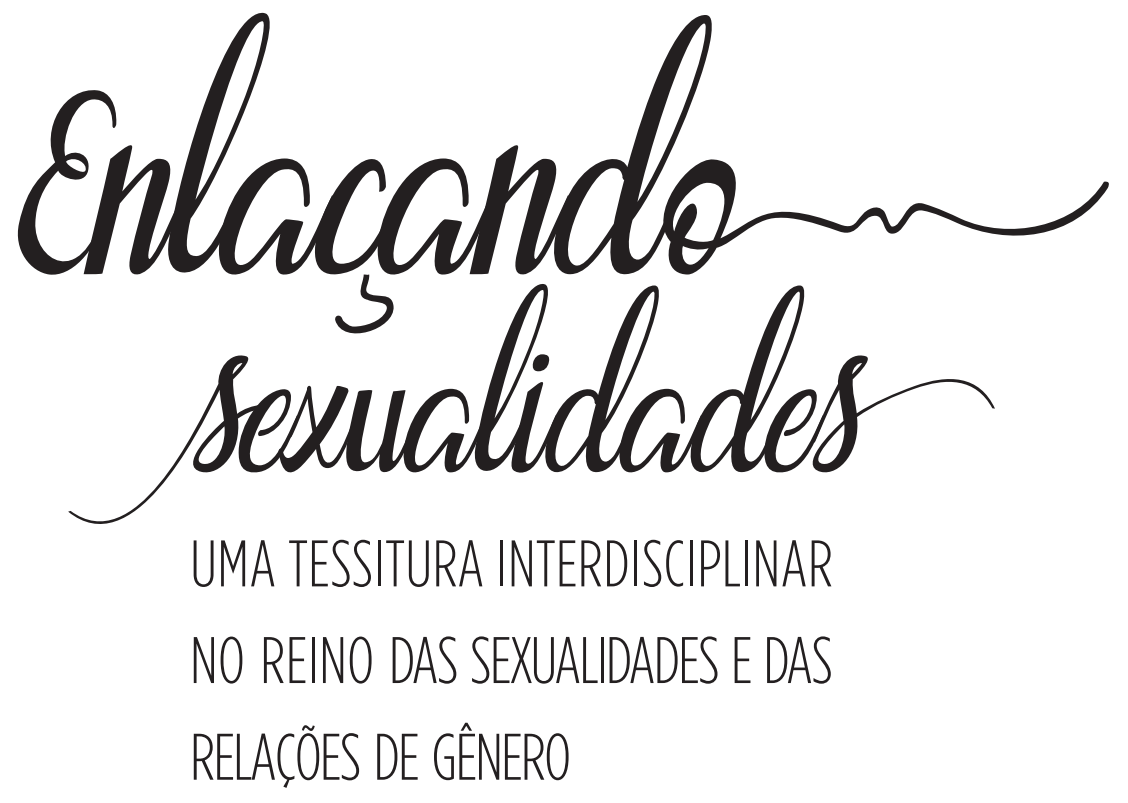


UNIVERSIDADE FEDERAL DA BAHIA

Reitor

Foão Carlos Salles Pires da Silva

Vice-reitor

Paulo Cesar Miguez de Oliveira

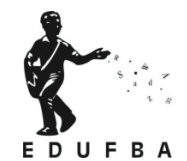

EDITORA DA UNIVERSIDADE FEDERAL DA BAHIA

\section{Diretora}

Flávia Goulart Mota Garcia Rosa

Conselho Editorial

Alberto Brum Novaes

Angelo Szaniecki Perret Serpa

Caiuby Álves da Costa

Charbel Niño El Hani

Cleise Furtado Mendes

Dante Eustacbio Lucchesi Ramacciotti

Evelina de Carvalho Sá Hoisel

Fosé Teixeira Cavalcante Filho

Maria do Carmo Soares Freitas

Maria Vidal de Negreiros Camargo 
SUELY MESSEDER • MARY GARCIA CASTRO • LAURA MOUTINHO

(Org.)

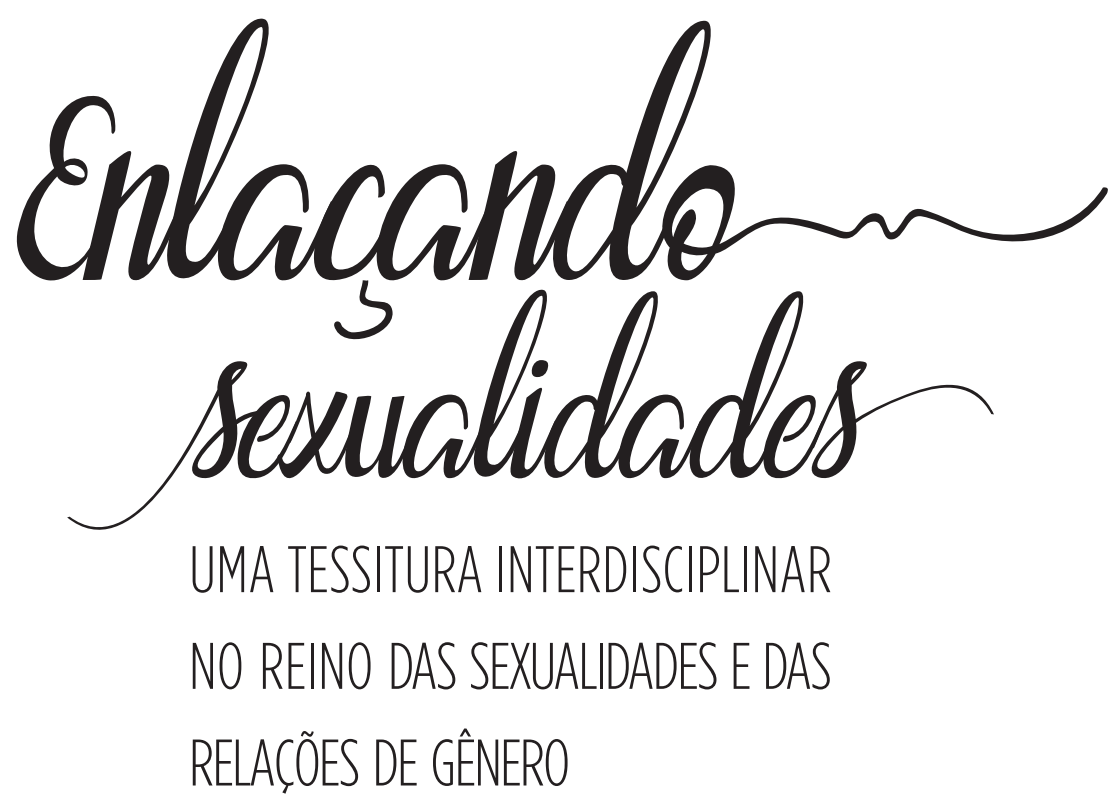

EDUFBA

SALVADOR

2016 
(C) Direitos dessa edição cedidos à Edufba.

\title{
Feito o Depósito Legal
}

\section{Capa e Projeto Gráfico \\ Genivaldo Oliveira}

\author{
Imagem da Capa \\ Ivana Portnay \\ Revisão \\ Alassol Queiroz \\ Normalização \\ Equipe da EDUFBA
}

Ficha Catalográfica: Fábio Andrade Gomes - CRB-5/I5I3

E57 Enlaçando sexualidades : uma tessitura interdisciplinar no reino das sexualidades e das relações de gênero

/ Suely Messeder, Mary Garcia Castro, Laura

Moutinho, organização. - Salvador : EDUFBA, 2016.

32I p.

Textos em português e espanhol.

ISBN 978-85-232-I546-O

I. Relações de gênero. 2. Sexualidade. I. Messeder, Suely, org. II. Castro, Mary Garcia, org. III. Moutinho, Laura, org. IV. Título: Uma tessitura interdisciplinar no reino das sexualidades e das relações de gênero.

CDD: 306.8

\section{Editora afiliada à}
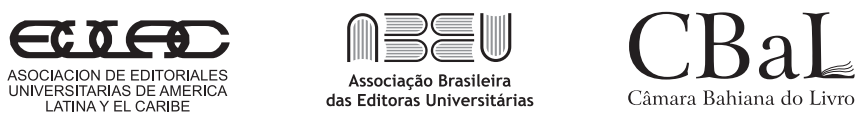

\section{EDUFBA}

Rua Barão de Jeremoabo, s/n - Campus de Ondina

40I70-II5 - Salvador - Ba-Brasil

Tel.: +55 71 3283-6164

Fax: +55 7I 3283-6I60

www.edufba.ufba.br | edufba@ufba.br 


\title{
SUMÁRIO
}

\author{
㴊 \\ 09 \\ Introdução \\ Suely Aldir Messeder
}

I7

Blanqueamiento social, nación y

moralidad en América Latina

Mara Viveros Vigoya

4I

Família, modos de usar e abusar. Maternidade e deslocamentos ou ensaiando indisciplinas

Mary Garcia Castro

67

Por uma microfísica do saber:

os contornos da família

Fosé Euclimar Xavier de Menezes,

Fernanda Andrade Leal

8I

Falas de que família(s)?

Era uma vez papai, mamãe e filho(s)

Enézio de Deus Silva fúnior 


$$
\text { 9I }
$$

O Programa Bolsa Família a partir das crianças beneficiadas: uma abordagem das moralidades engendradas pela condicionalidade escolar Flávia F. Pires

IO9

Homossexualidades como processo educativo e construção discursiva Anderson Ferrari

\section{I27}

"Eu me sentia assim, meio que excluído": performances hegemônicas e as dissidências na escola

Marcio Caetano, Paulo Melgaço da Silva Funior, Treyce Ellen Silva Goulart

$$
\text { I57 }
$$

Pedagogias do corpo: é possível a escola ser um espaço de reconstrução?

Cássia Cristina Furlan, Eliane Rose Maio

\section{I79}

"Nem toda a gente gosta do diferente": literatura, (de)formação do leitor e diversidade Emerson Inácio 201

A literatura e as constelações familiares: como instaurar outros "melhores mundos possíveis" Renata Pimentel 223 (Micro)políticas Queer Fernando Pocaby 
235

Poder psiquiátrico e transgeneridade: em torno da verdade diagnóstica

Beatriz Pagliarini Bagagli

\author{
249 \\ Pensando a cisgeneridade como \\ crítica decolonial \\ Viviane Vergueiro
}

27I

Moralidades: quando a heterogênese ética se mostra criadora e livre de juízos de valor bipolares

Dante Augusto Galeffi

287

Gabriela Leite - histórias de uma puta feminista

Letícia Cardoso Barreto, Claudia Mayorga

309

Sobre as organizadoras

313

Sobre os autores 


\section{Introdução}

De lá pra cá são quase Io anos de existência do Seminário Enlaçando Sexualidades, motivo de sobra para comemorarmos, sobretudo, pela possibilidade de publicarmos nossas palestras transformadas em textos neste livro.

Digo transformadas porque não existe uma mera transcrição em nossas falas transcorridas nas mesas no decorrer dos dias 27, 28 e 29 de maio de 2015, mas sim parafraseando Emerson Inácio em seu texto aqui publicado, quando nos alerta sobre a função da literatura:

função reformadora ou, talvez, deformadora que a literatura tem, não só de se demarcar como uma outra linguagem distinta das mídias e suportes mais usuais, mas, sobretudo como forma de linguagem em que se estabelece também a diferença: pela exposição daquilo que o senso comum majoritário consideraria não literário, não digno de representação e antissublime é a que a literatura, efetivamente, hoje se faz. 
As nossas falas, quando transformadas em literatura científica perde a sua função de informar para uma audiência viva, perde na ambiência dos murmurinhos, perde na riqueza dos gestuais incorporados na cena. A nossa fala transformada em texto ganha uma linguagem distinta que se estabelece em regras publicáveis regidas pela Associação Brasileira de Normas Técnicas (ABNT) e pela editora. E daí, a linguagem científica não consegue alcançar o mesmo público, felizmente as nossas falas não morrem em nossos textos, elas permanecem possivelmente na memória das múltiplas audiências que circulam no Seminário Enlaçando Sexualidades. Estas múltiplas audiências constituíssem em diversas comunidades de saberes, não somente a científica.

Por falar nas diversas comunidades de saberes que circulam no Enlaçando Sexualidades é preciso registrar o Prêmio Gabriela Leite pensado por Claudia Mayorga eacolhido em nosso território. Curiosamente, esse prêmio provocou por parte de um pesquisador presente, embora estrangeiro dos estudos sobre sexualidades e relações de gênero, uma surpresa, e ironicamente, ele retrucou-me: esse prêmio será qualificado em nosso currículo lattes, o Conselho Nacional de Desenvolvimento Científico e Tecnológico (CNPq) e a Coordenação de Aperfeiçoamento de Pessoal de Nível Superior (Capes) irão reconhecê-lo? Certamente, este prêmio não terá o reconhecimento das agências de fomento e de regulamentação do "fazer científico", mas Gabriela Leite possui uma história no campo da militância. A história de vida, as experiências, os pensamentos eas ideias de Gabriela Leite nos promove reflexões menos preconceituosas sobre a prostituição feminina. Teremos oportunidade de ler sobre esta mulher em nosso último artigo escrito a quatro mãos por Letícia Cardoso Barreto e Claudia Mayorga.

Tecer comentários sobre mulheres prostitutas nos coloca no lugar político dos sujeitos abjetos, e nos permite contextualizar Salvador, território do Seminário Enlaçando. No inicio do mês de maio, um pouco antes deste evento, chovia torrencialmente e, em consequência, corpos de mulheres e homens pretos e pobres baianos padeciam soterrados. Esta tragédia pre- 
viamente anunciada não é fenômeno novo. Foram 2 I corpos soterrados pelos deslizamentos de terra em bairros pobres. Eles e elas foram anunciados na televisão com nome e sobrenome, embora verdadeiramente, como nos diz Galeano em seu poema "Los nadies”: "Que no tienen um nombre, que tienen un número”, eles e elas foram apenas números em nossa urnas, e tornaram-se fácil e tragicamente: 2I corpos sem vida.

Velhas urgências e novas e efetivas políticas públicas preventivas, cujas materialidades não se revelam pelas festas, pelas grandes construções. Políticas públicas preventivas não fascinam os olhares ávidos constituídos pela espetacularização das imagens, mas têm a ver com outros sentidos que importam menos em nossas relações do cotidiano. Tais corpos pouco importaram.

Sobrelevo que essa insólita tragédia não é somente causada pelas catástrofes naturais ou supostamente tão naturais - mas também pela violência do cotidiano que massacra a juventude negra - jovens homens negros que morrem, mulheres que morrem ao abortar em estatísticas subnotificada. Sabemos que morrem mulheres negras, travestis e transexuais mortos, putas. Em verdade tais pessoas não morrem! São mortas! E, com tudo isso, fabrica-se o pânico moral, e ele se infiltra, se transmuta em rizomas e se pulveriza em nossas interações cotidianas.

E por falar em pânico moral, tentarei articular como fio condutor as moralidades e famílias como estruturantes desta publicação, embora outros temas apareçam na circularidade das sexualidades e das relações de gênero. Por isso, intitulamos o nosso livro Enlaçando sexualidades: uma tessitura interdisciplinar no reino das sexualidades e das relações de gênero. Gosto de pensar "na moral" a partir da Genealogia da Moral, porque narramos sobre a crueldade humana para além do bem e do mal e da dicotomia natureza e humanidade.

Com isto, me reporto a uma conversa entabulada, nos idos de 2000 no congresso da Associação Brasileira de Estudos Populacionais (ABEP) com um homem negro, baiano, baixinho: 
Rapaz para me impor com esse corpinbo, entre nós da periferia, eu tive que me virar e dai me reconbecer e reinventar novas estratégias de sobrevivência. Sei muito bem o que é o mau e o bom e nunca tive pretensões de negar a mim mesmo. Veja bem, com tantos limites físicos, tive que entender que a minba ruindade e bondade residia em mim mesmo.

Curiosamente, essa conversa transladou-se no tempo, e consigo abreviá-la na moral do nobre e na moral do escravo e entendê-la partindo do corpo como referência. Aqui não pretendo me embrenhar no debate nietzschiano. Desejo tão somente sublinhar que nós, Marias e Joãos Ninguéns, temos como ponto de partida o corpo e não a negação dele. $\mathrm{O}$ corpo como a nossa morada e a morada da razão e, daí penso o corpo encarnado racializado, engendrado, cujo conteúdo e forma comporta num único golpe os marcadores sociais considerados negativos.

E somos nós que nos arvoramos a fazer ciência? Nós, os destituídos de uma razão pura. Nós, que somos a morada do nosso corpomente e mentecorpo, e não queremos negá-los como foi falsamente negado. Nós, exatamente os imorais destituídos das relações simbólicas positivas. Nós, que nos erguemos em nossas inutilidades e nunca louvamos as nossas ações - porque simplesmente reagimos. Nós que crescemos com algo na cabeça imaginado como ruim - o cabelo. Nós, os condenados da terra e, certamente, nós, que devemos nos interpelar sobre como reagimos/agimos aos tentáculos da Ciência do Norte.

Em 20I4, no Seminário Gêneros e Sexualidades em Fluxo fui provocada por Miriam Grossi a pôr em visibilidade a imagem da Ciência que pratico e, em resposta, me reportei à utopia na qual concebo a Ciência que pratico nos projetos contemplados nos editais das agências de fomento. Tal ciência tem como princípio a colaboração e o compromisso entre nós pesquisadores(as), contrapondo-se a uma ciência competitiva.

Como aprendo muitíssimo como a produção escrita de Mãe Stella de Oxóssi, invisto sobre o seu conceito de Compromisso, e tenho em alta estima o Compromisso não, meramente como uma reação, mas sim, como 
uma ação fortalecida em minha ancestralidade. Em 20I4, no VII Congresso Internacional de Estudos sobre a Diversidade Sexual e de Gênero da Associação Brasileira de Estudos da Homocultura $(\mathrm{ABEH})$, tive oportunidade de desenvolver a ideia de compromisso articulado com a ideia de rede de coalizão, cujo interesse é reunir pesquisadores(as) em seus saberes localizados numa teia mais colaborativa. Possivelmente essa publicação é fruto desta rede de pesquisadores(as) que se encontram nestes territórios de produção de saberes científicos e ativismo acadêmico.

Nesta coletânea reunimos texto que compuseram o "fazer interdisciplinar" do reino das sexualidades e das relações de gênero seja pelos temas desenvolvidos, seja pelo campo disciplinar que se alocam os(as) nosso(as) pesquisadores(as). Ao longo do livro somos convidados(as) a ver essa proliferação de linguagens quando nos deparamos com a escrita de antropólogos(as) sociólogos(as), psicólogos(as), advogados(as), educadores(as), filósofos, profissionais de letras e comunicólogos. Curiosamente, as caixas disciplinares sofrem abalos sísmicos provocados pelos dispositivos das sexualidades e das tecnologias de gênero, uma vez que a "fictícia" rigidez das fronteiras disciplinares e dos seus respectivos objeto de estudo inventada pela modernidade não nos ajuda a responder aos problemas complexos e híbridos que enfrentamos em nossos cotidianos. Para além da rigidez fronteiriça arrostadas por nós, atravessamos uma época marcada por pesquisas desenvolvidas pelos sujeitos, outrora vistos como "objeto de estudo", nesta caso mais específico são os(as) pesquisadores(as) transexuais que investigam e discursam sobre suas posições no mundo.

Daí, voltamos os nossos olhares para os textos que nos foram encaminhados pelos autores que compuseram as mesas e ministraram asconferências. Começamos com Mara Viveros com seu texto "Blanqueamiento social, nación y moralidad en América Latina” a autora nos envolve em sua escrita descortinando o processo de branqueamento e suas contações morais em terras latinas.

Em seguida navegamos com a produção do Programa de Pós-Graduação em Família na Sociedade Contemporânea da Universidade Católica 
do Salvador (UCSal) com os textos de Mary de Castro, José Menezes e Fernanda e, por fim Enézio de Deus. Coincidentemente, nos idos de 1964, assistimos a Marcha da Família com Deus pela Liberdade, e mais recentemente presenciamos em menos de um mês da realização do Seminário Enlaçando, a reedição deste movimento conservador, embora apenas intitulada Marcha da Família. A primeira marcha nos conduziu para uma análise histórica e contextualizada do Golpe de I964, ela foi protagonizada por setores católicos da classe média urbana, bem como por políticos conservadores (a Ação Democrática Parlamentar), pela elite empresarial - reunida no Instituto de Pesquisas e Estudos Sociais (IPES) e pelos movimentos femininos. Aqui, arriscamos a analisar que, 50 anos depois, assistimosa segunda Marcha da Família como uma espécie do prenúncio do Golpe Contra o Governo da Presidenta Dilma. No livro Deus, Pátria e Família: as mulberes no golpe de 1964, Solange Simõesnos explica que a inserção das mulheres foi estratégica na conspiração que desembocou no golpe. Na marcha atual, a mídia responsabiliza a Cristina Peviani, como das organizadoras do evento, cujo objetivo dela seria "fazer valer a ideia de que existe a família conservadora no Brasil”.

Certamente, o texto de Mary Castro nos arranca deste marasmo ideológico sobre esta família conservadora no Brasil, e nos traz à tona a família, cujo chefe da casa é a mulher. Neste caminho, a autora nos conduz aos modos de valorar o binômio família e maternidade em algumas perspectivas feministas, e daí nos lembra da história recentesobre a mãe do "bandido", morto, que da sua dor tira coragem para brigar por lhe dar a dignidade de um túmulo, ecoando dores de muitos, denunciando genocídios, como dos jovens negros neste Brasil pelo Estado policial. Com isto, Castro nos convida a deslocar a relação família e maternidade, para maternidade e sociedade, a mãe pública, figura que vem se fazendo cada vez mais presente, tirando a ética do cuidar do pequeno mundo da família, desafiando Estado, um estado de coisas, a desumanização destes tempos de barbárie. 
Em seu texto, "Por uma microfísica do saber: os contornos da família”, José Menezes e Fernanda Leal se debruçam na obra Primeiro Volume de História da Sexualidade e a interrogam: a) é a família uma força de saber e de poder sobre a sexualidade de seus membros na letra de Michel Foucault? b) Qual é o estatuto dessa força? c) O que resulta do emprego dessa força sobre as subjetividades em constituição no seio da família?A preocupação dos autores é mostrar a ancoragem da psicanáliseno conceito de família. Quando mergulhamos nas "Falas de que família(s)? Era uma vez papai, mamãe e filho(s)...”, nos deparamos com os comentários de Enézio de Deus sobre a mesa "Novos e velhos arranjos familiares", cujo objetivo era expor as diversidades de família estruturada em nossas realidades, tais como: a) a chefia feminina na família baiana é decorrência da ausência do cônjuge e da falta de responsabilização dos pais (homens); b) a homoparentalidade; c) o poliamor. $\mathrm{O}$ autor nos provoca a refletir sob a perspectiva jurídica.

$\mathrm{Na}$ trilha da família nos deparamos com a infância, obviamente ela não poderia escapar ao debate das moralidades, com isto, nos deparamos com o texto "O programa bolsa família a partir das crianças beneficiadas: uma abordagem das moralidades engendradas pela condicionalidade escolar" de Flávia Pires, ela nos revela a interpretação que as crianças conferem à bolsa família em seu cotidiano escolar.

O debate entre educação e sexualidade foi tema privilegiado nas edições anterioresdo Enlaçando e não poderia ser diferente em nossa quarta edição, sobretudo pela nossa estreita relação com a Associação Brasileira dos Estudos sobre Homocultura (ABEH), que teve em seu VII Congresso Internacional de Estudos sobre a Diversidade Sexual e de Gênero a centralidade neste tema. Neste livro contamos com os textos Anderson Ferrary, Marcio Caetano e Eliane Maio que nos possibilita compreender como as sexualidades influenciam na vida dos estudantes.

Ainda, como herdeiros da $\mathrm{ABEH}$, atentos ao despontar e na vanguarda dos estudos sobre homossexualidade (homocultura) na literatura, temos os textos "Nem toda a gente gosta do diferente: literatura, (de)formação do 
leitor e Diversidade" e "A literatura e as constelações familiares: como instaurar outros 'melhores mundos possíveis", respectivamente de Emerson Inácio e Renata Pimentel.

Caminhando na trilha do livro contamos com a escrita dos artigos elaborados por Bia Pagalhiri e Viviane Vergueiro, que nos permite o giro na formulação inteligível dos corpos masculinos e femininos, e com muita sabedoria apreciamos as ideias dos trans-feminismos, dos trans-corpos, das trans-sexualidades através das autoras. Para se afinar com o debate do trans-feminismo e as limitações do debate teórico feminista no campo das sexualidades, cotejamos o texto "Micropolíticas queer" de Fernando Pocahy. $\mathrm{O}$ autor nos convida a surfar sobre uma linguagem contaminada com palavras inventadas, por sua vez este neologismo nos reencata e nos produz uma vontade de nos encontrarmos com uma nova linguagem para além do androcentrismos, seximos e "lgbtfobias", com isto, nos reporta aos ensinamentos de Julia Kristeva.

Por fim, concluímos o nosso livro tecendo ideias no âmbito da filosofia sobre moralidades ética com Dante Galeffi em seu texto "Moralidades: quando a heterogênese ética se mostra criadora e livre de juízos de valores bipolares", em seguida temos, não por acaso, o nosso último texto, "Gabriela Leite - histórias de uma puta feminista”. Nele, as autoras buscam destacar alguns pontos da trajetória pessoal e política de Gabriela Leite com o desejo de expor alguns dos legados que essa "puta feminista" deixou para a luta pelos direitos humanos das mulheres prostitutas. 


\title{
Blanqueamiento social, nación y moralidad en América Latina ${ }^{\mathrm{I}}$
}

\author{
灌 \\ Mara Viveros Vigoya
}

\section{Introducción}

En esta ponencia voy a rastrear cómo han interactuado el blanqueamiento social y la moralidad, en América latina mostrando las continuidades y discontinuidades que han tenido estas percepciones desde el período colonial y en relación con la constitución progresiva del significado contemporáneo del término raza para clasificar a las poblaciones según criterios que entrelazan

\footnotetext{
${ }^{1}$ Por se tratar de texto em língua estrangeira, preservaremos a estrutura textual e normas técnicas do país de origem, sendo de total responsabilidade da autora a forma apresentada e adotada.
} 
características fenotípicas y cualidades morales que pueden ser transmitidas de generación en generación (Hering 2007, Leal León 2010). Como sugiere la presentación del Seminario voy a dar cuenta de reglas, normas, pausas, y tensiones que operan en esta relación y en sus efectos tanto para las interacciones cara a cara, como para las relaciones institucionales.

Antes de dar cuenta de la historicidad del proceso de este proceso desde el periodo colonial voy a hacer dos precisiones. La primera, se refiere al uso que hago de la categoría América Latina. Si bien es claro que hay muchas diferencias entre los países que componen esta región e incluso hay muchas variaciones internas al interior de un mismo país, para el propósito de esta conferencia me parece pertinente subrayar algunos puntos comunes que comparten estos países: uno de ellos es el lugar que ocupa el mestizaje en sus historias como un proceso que ha sido culturalmente estructurante y como una ideología política nacionalista. Otro, es la estrecha relación que tienen la raza, la etnicidad, la clase, el género y la sexualidad en las dinámicas sociales de la región y la forma en que las identidades sociales marcan, matizan o reinterpretan las diferencias culturales, sociales o biológicas heredadas.

La segunda precisión es explicar que entiendo por blanqueamiento la búsqueda de escapar de lo "negro" para asegurarse una mejor forma de existencia social en un contexto que valora lo "blanco" como sinónimo de progreso, civilización y belleza. Esta búsqueda se lleva a cabo de dos modos, primero, a través del mestizaje en un proceso intergeneracional, y en segundo lugar, a través de la integración a redes sociales no negras. Mientras que el primero es evidente en la apariencia física, estoy más interesada en el segundo, porque revela la dinámica social en juego. En lo que llamo blanqueamiento social interactúan distintas fuerzas: ideológicas, sociales y personales. La dimensión ideológica del blanqueamiento social ha sido construida en relación con una identidad nacional que privilegia lo blanco, o lo que se acerca a él, y restringe el espacio social y simbólico que ocupan las poblaciones indígenas y afrodescendientes; la dimensión social alude a las dinámicas que actúan para "diluir y dispersar lo negro 
y la cultura negra" (Wade 1997: 350) y la dimensión personal incluye las diversas prácticas cotidianas que realizan los grupos e individuos sociales identificados como no blancos para adecuarse a los valores culturales, sociales y morales "blancos"

Hechas estas dos precisiones voy a referirme al blanqueamiento y a sus connotaciones morales desde una perspectiva que busca dar cuenta de la forma en que las categorizaciones sexuales y de género han sido históricamente configuradas en relación con las categorizaciones de raza”

\section{Orden Colonial: honor, sexualidad y religión}

En el contexto colonial latinoamericano, la certificación de limpieza de sangre - que operaba en la península ibérica y exigía documentar una ascendencia sin mácula religiosa de judíos o musulmanes - se transformó paulatinamente en la necesidad de probar no tener ancestros negros, mulatos, zambos, cuarterones, etc., visibles en el color de la piel y en ciertos rasgos fisionómicos (Hering 2007, 2010). Al mismo tiempo, la misma dinámica colonial que creó las castas permitió procesos de ascenso social por blanqueamiento, posibilitando a "indios" y "negros" sobrepasar los límites que su condición les imponía mediante un proceso de sucesivos mestizajes a través de varias generaciones (Leal León 20Io).

No hay que olvidar, sin embargo, que la blanquidad era también una cuestión de reputación, ya que una persona podía ser blanca si así era considerada públicamente (Wade 2009: 70). Las informaciones provenientes de distintos documentos oficiales permiten afirmar que "el color se convertía fácilmente en un instrumento de poder, aplicable ante la ley colonial para conseguir ciertos fines [...]. El color, igual que la memoria, era una categoría moldeable en la cotidianidad y que se definía según la situación.” (Hering 20I0: 144).

En una sociedad altamente estratificada como la de las colonias ibéricas, los blancos ocupaban la cúspide de la pirámide, los indios y los negros estaban en la base (si bien los indios gozaban de protección legal y los negros 
no), y el espacio social intermedio estaba dominado por una amplia variedad de no blancos legalmente libres. La escasez de mujeres blancas, la falta de control sobre amplias zonas del territorio y las medidas legales que permitían a los esclavos comprar su libertad propiciaron el surgimiento de una población mezclada racialmente y socialmente reconocida, que se convirtió en la mayoría en varias áreas del territorio a partir del siglo XVIII.

En la medida en que la categoría de personas mezclada creció numéricamente y en algunos casos consiguió riqueza y estatus social, el asunto del estatus racial cobró mayor importancia para la elite blanca. Así, la regulación del matrimonio y el parentesco, y de ciertos actos sexuales, a través de leyes y decretos, se convirtió en una cuestión clave para mantener estas jerarquías y preservar los privilegios político-económicos que conferían el honor y la pureza de sangre. En esta operación fue crucial el control del comportamiento sexual de las mujeres de la elite, consideradas como los agentes que podían traer contaminación al interior de la familia, amenazando la pureza de sangre que definía en buena parte la posición social de la elite en la jerarquía social y racial.

La castidad o "virtud de las mujeres" (esposas, hermanas, madres, hijas) se convirtió entonces en el significante del honor familiar. En concordancia, las mujeres blancas de la elite ocultaron o interrumpieron los embarazos fruto de uniones con hombres de menor rango social para preservar la continuidad del sistema que privilegiaba a los hombres blancos. Las mujeres no blancas o pobres quedaron mientras tanto expuestas a asaltos masculinos que muy fácilmente podían mancillar su honor y devaluar su estatus social. El honor como estatus social y el honor como virtud estaban tan inextricablemente unidos que las únicas que podían aspirar realmente al honor y al estatus social que le estaba asociado, mediante un comportamiento adecuado, eran las mujeres blancas de la elite.

La institución que permitió conectar la dominación sexual con la dominación racial, y al Estado con la familia para definir el estatus social fue el matrimonio. Ahora bien, a pesar de que se buscó dar prioridad al matrimonio entre iguales social y económicamente" esta regla tuvo su excepción, 
como lo muestra VerenaStolcke (1992) para el caso de la sociedad cubana decimonónica. Las parejas que deseaban casarse con alguien que fuera considerado por sus padres como socialmente desigual, recurrían al rapto de la mujer como una estrategia para legitimar la unión nacida de la deshonra a la que se había expuesto por tener una relación por fuera del matrimonio. No obstante, este tipo de acciones se prohibió por medio de una coerción mayor, ya que el riesgo que enfrentaba la Corona Española con el creciente número de mezclas formadas a través de estas uniones interraciales era alto.

Entretanto, las relaciones extramatrimoniales incluso interraciales no impugnaban la honorabilidad personal de los varones. Sin embargo, se intentó limitar estas prácticas, no tanto por razones morales sino porque podían desestabilizar la seguridad del estatus de la élite al ayudar a crear una clase mixta de la cual surgían individuos que aspiraban al honor y al estatus asociado y podían conseguirlo mediante peticiones a la Corona española la Palacio de Justicia en Brasil (Wade 2009: 96). Las políticas que impidieron el matrimonio interracial en el periodo colonial fueron siempre un tema de tensiones y controversias, cuyo trasfondo era la búsqueda de continuidad de un orden social basad en jerarquías de raza y sexo. No hay que olvidar que en América Latina y particularmente en el Caribe todavía subsistía el pánico suscitado por la revolución haitiana (I79I-I804) que constituyó la primera república negra independiente convirtiendo a la isla en un escenario peligroso para la corona española.

Aunque el honor fue un valor ampliamente aceptado en el periodo colonial, la gente del común parece haber intentado resistido a su mandato desarrollando una perspectiva distintiva en relación con la moral. Por ejemplo, las uniones consensuales fueron muy frecuentes entre las capas plebeyas de las ciudades coloniales de México, Lima y Santa Fe y parecen haber sido aceptadas como una norma cultural de ese grupo. Igualmente, tener hijos fuera del matrimonio no impedía necesariamente a una mujer del común poder realizar más tarde un matrimonio y la castidad femenina tenía un valor menor que en la elite (Cope i994: 69 citado por Wade 
2009). Sin embargo el matrimonio fue una institución ampliamente valorada por toda la población y era una meta a la que se aspiraba

Los códigos de honor tuvieron diferentes perspectivas para mujeres y hombres: para éstos, el honor podía depender en gran medida del poder de su autoridad y no se afectaba por relaciones sexuales o arreglos familiares y parentales con mujeres de clases sociales y grupos étnico raciales percibidos como inferiores, mientras que para las mujeres, podía depender más o provenir directamente de su familia. Por esta misma razón, las maneras de resistir a sus mandatos también estuvieron bastante orientadas por su posición de género. Las mujeres de las castas intentaron acceden al honor, así fuera parcial, para ellas o para sus hijos retando las jerarquías raciales a través de uniones interraciales. $Y$ en otros casos, se ampararon en los valores coloniales del honor y del respeto merecido para justificar su participación en actos insurgentes (Stern 1995:302-8).

Un ejemplo interesante de resistencia femenina indígena frente a la colonización ibérica es el descrito por Irene Silverblatt (1987) en su libro sobre las ideologías de género y clase en el imperio Inca y el Perú coloniales: Silverblatt se refiere al caso de las acllas o vírgenes andinas, mujeres de singular belleza, destinadas al culto religioso y en algunos casos asignadas como esposas para el emperador u otros hombres de importancia. Estas mujeres tenían a su cargo la preparación de comidas protocolares y la costura y el tejido de ciertos elementos rituales. En las nuevas condiciones que impuso la colonización su virginidad cobró un nuevo significado, convirtiéndose en una medida de protección que las llevó a aislarse en la Puna (meseta) para desaparecer tanto de los ojos de los conquistadores para evitar su lujuria, como de la vigilancia de las autoridades coloniales.

Pese a los intentos de los sectores subalternos de resistir a la imposición de valores sexuales y morales por parte de los españoles no era muy fácil articular exigencias de derechos y defensas contra los abusos por fuera del contexto axiológico y religioso dominante (Villegas del Castillo Historia Critica, 2006). Así, las demandas que las y los plebeyos hicieron 
ante las autoridades judiciales solicitando su intervención en los conflictos familiares invocaron el mismo ideario cultural de las elites

En su libro Race and Sex in Latin America Wade reporta como ejemplo de resistencias a las normas morales dominantes el de las "comunidades de sodomitas 'establecidas en las ciudades coloniales y estudiadas por Luiz Mott en Brasil. Si bien este trabajo ha sido criticado como esencialista, por plantear la existencia de una subcultura gay embrionaria en Brasil, por utilizar en forma anacrónica el termino gay, propio del siglo XX, no es improbable que hayan existido redes más o menos organizadas, gestadas en las iglesias, los campos de cultivo o las playas, cuyo objetivo era asegurar la posibilidad de mantener prácticas sexuales disidentes.

En el intento de preservar el orden social, sexual, racial y moral de esta nueva sociedad, orientada por los principios ibéricos pero adecuados a las condiciones locales, las autoridades coloniales echaron mano de otra institución, la de la Inquisición. Los colonizadores españoles y portugueses vincularon la inmoralidad sexual al paganismo y persiguieron la brujería, no únicamente como herejía sino también como un ámbito muy sexualizado. Gran parte del contenido del Malleus Maleficarum, el manual utilizado por los tribunales de la Inquisición establecidos en México y Lima en I569 y posteriormente en Cartagena de Indias en i6ıo, hacía referencia a asuntos relacionados en mayor o menor medida con la sexualidad.

Si bien muchas de las ofensas buscadas se clasificaban como blasfemia y herejía, trabajos como el de Luiz Mott en Brasil señalan que muchos de los sacrilegios investigados por la inquisición en Brasil tenían contenidos sexuales. Mientras las prácticas homoeróticas masculinas fueron susceptible de persecución, las prácticas "nefandas" de las mujeres fueron rara vez causa de preocupación. Según la investigación bibliográfica realizada por Wade, la distinción actividad/pasividad sexual fue claramente utilizada para reforzar las ideas de dominación de género; sin embargo, los pocos datos existentes sobre el aspecto racial de las prácticas homosexuales no autorizan afirmar o negar que las prácticas homoeróticas reforzaron o socavaron las jerarquía raciales. 
Aunque todos los residentes de la colonia eran susceptibles de ser denunciados ante la inquisición, es evidente, como lo muestra Jaime Borja para Colombia que la sexualidad de las poblaciones negras, indígenas y mestizas fue sometida a un más estricto escrutinio. De este modo, concubinato, adulterio y sodomía fueron pecados asociados muy frecuentes con las poblaciones racializadas y la brujería se asimiló con la prostitución y los comportamientos sexualmente licenciosos (Wade: 2009: 85). Las instituciones que perseguían a las brujas y a la heterodoxia religiosa imponían simultáneamente un orden moral-sexual y racial: así, aquellos considerados indios, negros y mestizos fueron percibidos muy frecuentemente como sexual y religiosamente heterodoxos. En Brasil, por ejemplo, el término mandingueiro, derivado de la etnia Mandinka de África del Oeste, se convirtió en sinónimo de hechicero. En los Andes, las campañas religiosas que buscaron extirpar la idolatría se focalizaron sobre las poblaciones indígenas, y particularmente sobre las mujeres que no solo fueron tildadas de paganas sino de sexualmente inmorales. Sin embargo, aún con la amenaza de la inquisición en este periodo también se generaron espacios de libertad y autonomía sexual y ni este ni ningún otro sistema de represión fue capaz de llegar a cada individuo y grupo social.

En resumen, en el periodo colonial los dispositivos de pureza de sangre que hacían referencia inicialmente únicamente a la religión se convirtieron en mecanismos de dominación racial que operaron a través de normas patriarcales para producir una descendencia legítima, salvaguardar los privilegios materiales y simbólicos de las élites y garantizar la continuidad de este orden colonial (Wade 2009: 9I).

\section{Las normas sociales de sexo y género en el surgimiento de las nuevas republicas}

A partir del inicio del siglo ig, la disolución del Imperio Español en América (como fruto de las luchas por la Independencia) planteó el problema del nuevo orden social. Libradas a su suerte, las excolonias ibéricas del norte y del sur de América enfrentaron la necesidad de garantizar y normalizar un 
nuevo equilibrio y unas nuevas formas de autoridad política. Igualmente, debieron lidiar de distintas formas con el dilema planteado por la composición racial de sus poblaciones -visiblemente mezcladas- en relación con el deseo y la voluntad de acceder a las ventajas del progreso y la civilización propios de las naciones modernas. La disyuntiva que trazaba la composición racial de las poblaciones exigió crear un espacio político importante para los problemas de la raza, categoría que ocupó un lugar relevante en el pensamiento científico occidental de la época y fue el concepto que permitió articular la modernidad con la blanquitud (Wade 2009: II4).

Sin embargo, la lógica de clasificación racial que diferenciaba grupos considerados provistos o desprovistos de determinados atributos por naturaleza, entraba en contradicción con el nuevo modelo de ciudadanía que pretendía fundar la legitimidad del poder político republicano. Por ello, una vez eliminadas las diferencias legales, las categorías raciales se volvieron más fluidas y el mestizaje empezó a ser valorado como característica de las nuevas naciones. El mestizaje, como una forma de blanqueamiento progresivo, se convirtió en una promesa de inclusión en la comunidad de ciudadanos² no solo a través de los casamientos con personas "más blancas" sino por adecuación a los valores de respetabilidad y honor considerados propios de los grupos construidos como blancos. De este modo, el mestizaje pudo ser una fuente de estatus que podía reivindicarse ya sea como atributo natural o como resultado de un proyecto personal, no solo aceptado sino deseado (Moreno Figueroa, 20I2).

A la preocupación decimonónica por la consolidación de un Estado nación, se sumó un proyecto de modernización nacional en el cual jugaron un papel relevante políticos y médicos. Convencidos de que el progreso de un país requería de la participación de todos los nacionales, y basados en un discurso biológico que le atribuía ciertas características "raciales" a las distintas poblaciones, médicos y políticos emprendieron

\footnotetext{
2 El uso del masculino para ciudadanos da cuenta de las restricciones que tenía el ejercicio de ciudadanía para las mujeres (Leal León 2010: 395); no sobra recordar que el derecho al voto femenino solo se logró en la segunda mitad del siglo XX, en 1957.
} 
campanas reformistas con el fin de mejorar la "raza colombiana”. Las ideas de vigor y salud en la regulación de la sexualidad fueron interpretadas en un marco nacional y el bienestar y la fortaleza reproductiva de la población constituyeron un nuevo horizonte político de los gobernantes. Los grupos racializados, que se ubicaban en la base de la pirámide social (permitiendo amalgamar clase social y raza), fueron convertidos en objetivos primordiales de la acción higienista y civilizadora de las élites blancas.

Así, la encrucijada que planteaba la composición racial de las poblaciones de las nuevas naciones necesitó la puesta en marcha de políticas higienistas, programas eugenésicos, medidas de renovación urbana y planes para incrementar el acceso a la educación y la extensión, a todos los grupos sociales, de los valores ligados a la modernidad. El higienismo operó, como lo recuerda Ángela Facundo (200) a partir de su análisis del caso colombiano, en los dos ámbitos establecidos para desarrollar el ideal del progreso: el ámbito remedial y el de formación. Lo remedial estuvo claramente encaminado a detener y revertir lo que muchos médicos consideraron una degeneración progresiva de la raza y lo formativo se orientó principalmente hacia la niñez con el objetivo de modificar los hábitos y costumbres desde la temprana infancia y hacia las madres, encargadas de velar por el cumplimiento de los preceptos modernos sobre el nacimiento, la crianza, la educación y el comportamiento en general.

La familia fue el foco de las estrategias remediales y formativas emprendidas para la reforma del pueblo colombiano y la mujer fue considerada como "la responsable de reformar a los hijos de la patria en aras de consolidar una nueva nación fuerte y vigorosa”. Por esta razón, una vez realizada la tarea de educación de las madres sobre el cuidado de los hijos, quedaba pendiente la tarea de formar el espíritu de las mujeres en la honradez y la virtud. Para ellas se delimitaron no sólo sus funciones como madres, sino también la edad ideal para casarse, iniciar la vida sexual, tener hijos y realizar cada tarea en función de su etapa de vida. Los tratados de economía doméstica y los manuales de buenas maneras buscaron extender el alcance de los programas higienistas y orientar a las mujeres a cumplir 
con sus obligaciones sin incurrir en vicios y costumbres que dificultaran el progreso nacional. La economía doméstica debía estar en consonancia con las prédicas del ahorro y la racionalidad de los recursos impuestas con el proyecto modernizador, de modo tal que una buena administradora del hogar, haría de este lugar un nicho acogedor para su esposo, alejándolo de los vicios del juego, el alcohol y la prostitución, para convertirse en padre y marido ejemplar, en un trabajador incansable y en un miembro productivo de la sociedad.

Estos textos, empleados desde finales del siglo XIX, se difundieron ampliamente como parte del dispositivo higienista. Vale la pena citar uno de ellos, referido por Ángela Facundo, para dar cuenta del carácter controlador de sus instrucciones y de las representaciones en boga sobre las mujeres y a feminidad:

La mujer que se levanta al aclarar el día puede emplear sin afán las dos primeras horas en el arreglo de su cama, cuarto, tocador y aún la casa toda; otra hora en el aseo y adorno personal y media hora en su desayuno; y ya desembarazada de estos quehaceres, tiene delante de sí más de ocho horas de cuyo buen uso podrá sacar grande utilidad. Sea cual fuere su oficio, o profesión, le será ventajosísimo no emprenderle hasta que haya puesto orden en su casa, y que su persona esté con el aseo y la compostura que permitan las circunstancias (Acevedo, I848:6).

Las mujeres fueron vistas y representadas por el discurso médico no sólo como madres biológicas sino también como madres morales de los hijos, la familia, la sociedad y la nación. El caso argentino estudiado por Donna Guy muestra los cambios en los conceptos de maternidad que trajo la participación e intervención médica en estados nación que alcanzaron la modernidad a finales del siglo ig. La salud pública nacional argentina como tal solo se organiza después de que se resuelven los problemas sanitarios urgentes, ligados a la llegada de continuas olas de inmigrantes europeos. En el contexto de las campañas de Salud que se emprendieron 
a comienzos del siglo XX para disminuir la mortalidad infantil, la madre moderna empezó a ser evaluada no solo por el número de hijos que podía dar a luz sino por su buena crianza. Un dato interesante del estudio de Guy es su referencia a la participación de las mujeres feministas en la definición de la maternidad, aceptada como un destino que debían cumplirlas mujeres modernas, mientras planteaban la necesidad de que las madres gozaran de independencia social y económica. De hecho, en el primer congreso femenino Internacional realizado en Buenos Aires en I9Io se expidió una declaración en la cual se invocaba que las madres, así fueran solteras o casadas merecían asistencia social. Escritoras feministas como Raquel Camaña vincularon la maternidad con la democracia y plantearon la centralidad que debía ocupar el proyecto de una democracia vital, anclado en la familia y aún más importante para la sociedad que el de la democracia política o industrial (Guy I99I).Los problemas planteados por la asistencia y la educación de niños abandonados que trajo la vida urbana requerían una imagen materna no solo afectuosa sino higiénica que incorporara elementos del conocimiento médico y psicológico de la época con miras a obtener un ejercicio adecuado de la maternidad. Por ello, la Sociedad de Beneficencia creó en I92I una escuela para enseñar a las madres como cuidar a sus hijos de acuerdo con los conceptos de la puericultura. Como dice Donna Guy, en la visión republicana de la maternidad las madres empezaron a ser importantes no solo por su vientre y su seno sino por sus conocimientos, su compromiso emocional y la conciencia de su deber patriótico.

$\mathrm{Al}$ igual que en Colombia y Argentina, en muchos países de la región, los médicos abanderados del proyecto higienista validaron su poder para representar a la sociedad en su conjunto con base en la efectividad atribuida a las disciplinas científicas y en su condición de varones letrados. De acuerdo con las corrientes del positivismo, el darwinismo social y la antropología forense, difundieron la visión de la degeneración adjudicada a las clases peligrosas y legitimaron su proyecto de limpieza social. En la categoría "clases peligrosas" incluyeron a tuberculosos, sifilíticos, alcohó- 
licos, prostitutas, vagos, mendigos, criminales, sediciosos, entre otros, pero también a los grupos racializados (Facundo 2006). La virtud sexual de estos grupos era motivo de desconfianza y se pensaba que su grado de moralidad no era lo suficientemente alto para poder asimilar las libertades que traía la modernidad. En este sentido, el origen indígena o africano de buena parte del pueblo latinoamericano fue percibido por sus clases dirigentes como un impedimento para el desarrollo nacional.

En Colombia por ejemplo, la representación de las clases populares bogotanas se vinculó a la figura de un indio maloliente, analfabeto, amenazado por la sífilis y poseído por el chichismo, enfermedad ocasionada por el abuso de la chicha, una bebida alcohólica producida con base en la fermentación del maíz. Y las chicherías fueron uno de los espacios más combatidos desde el periodo colonial, ya que alrededor de ellas se tejió todo una serie de estereotipos sexistas y racistas que afectó a las mujeres indígenas que eran sus propietarias o administradoras. En estos locales se subvirtieron los valores morales más arraigados en la sociedad de la época, dando cabida a encuentros erótico afectivos interraciales e interclase, sin vínculos matrimoniales y promoviendo la independencia económica femenina (Rodriguez) .

Vale la pena señalar que muchos lugares de socialización popular como tiendas, chicherías y campos de tejo, hacían parte del mismo lugar de habitación, incluyendo en ellos a las mujeres. Sin embargo, la separación de los espacios de socialización de los de habitación que propuso e impuso la industrialización (de la mano del higienismo) trajo consigo la segregación sexual del espacio y la reclusión de las mujeres el espacio privado. Con la difusión de la idea de que sólo las prostitutas frecuentaban estos lugares, la mayoría de las mujeres perdió la posibilidad de visitarlos, por lo menos de manera abierta y las mujeres de sectores populares y racializados que continuaron haciéndolo quedaron estigmatizadas sexualmente (Facundo 2006).

Para el higienismo, toda conducta femenina desviada de las buenas costumbres y rectitud moral podía tener repercusiones negativas en la sa- 
lud de una población en edad productiva. Así, la condena y persecución de quienes se dedicaban a la prostitución fue un elemento clave dentro de las políticas de la higiene social liberal. No solo había motivos de índole moral y de ordenamiento social, sino de la protección de la salud de las posibles víctimas de las enfermedades venéreas que incluyeron muchas veces a los miembros de los grupos dirigentes. Todo esto provocó el desarrollo de una estrategia médica dirigida desde el Estado, que buscó ejercer un control estricto de todas las prostitutas. Sin embargo, tal expectativa no pudo cumplirse, dado que gran porcentaje ejerció tal actividad sin estar debidamente registradas. El trabajo de Sueann Caulfield sobre la regulación de la prostitución en Rio de Janeiro a finales del siglo XIX y comienzos del siglo XX es un buen exponente de las contradicciones en que se debatía un país como Brasil en un momento en que pugnaba por mostrarse ante el mundo como una nación moderna. Como tal, debía exhibir una postura "abolicionista" o antirreguladora en relación con la prostitución; sin embargo en la práctica siempre se movía hacia el reglamentarismo y la utilización de represión policial.

Caulfield examina la historia de la gradual transformación de Mangue, un barrio situado lejos del centro de la ciudad, en un distrito de mala reputación regulado por la policía y objeto de intervenciones de saneamiento. Esta evolución es puesta en relación con las dos caras contrastantes de la prostitución carioca: la que ejercían con cierto refinamiento las francesas y las mulatas brasileras, toleradas, admiradas y protegidas por algunos hombres de las clases privilegiadas. Estas se ubicaban en Lapa, llamado el Montmartre tropical. Su contraparte era la prostitución que se ejercía en Mangue, escogido por la policía como depósito de las prostitutas "escandalosas”, las pretas y las europeas de clase popular, llamadas las polacas. El trabajo de Caulfield analiza igualmente los conflictos de poder entre profesionales, legisladores y oficiales de policía en torno a unas disposiciones reguladoras de la prostitución que pusieron de presente de forma muy explícita "los prejuicios raciales, étnicos y de clase que componían el ideal nacional de las elites brasileras" (Caulfield I998: I40). Los debates 
teóricos que suscitaron la prostitución y su regulación en este período muestran las distintas formas en que la raza, la etnicidad y la clase social se entrecruzaron con la sexualidad para crear las normas conyugales y familiares y las imágenes de nación que se buscaba construir.

En las distintas estrategias que buscaban apuntalar el orden nacional republicano, el dispositivo del honor continuó desempeñando un papel importante, pero con un nuevo significado. Ya no fue pensado, como en el período colonial, como una característica "natural" propia de las elites blancas, sino como una aspiración, ampliamente compartida, de adquirir la respetabilidad a través de la educación, la ocupación, la capacidad de entrega al trabajo y la adopción de una conducta moderada y virtuosa. Estos atributos fueron centrales en la formación de una cultura política republicana distintiva forjada en torno al respeto de la dignidad y de los derechos civiles de los hombres trabajadores del común. El cumplimiento de sus responsabilidades públicas los autorizó a ejercer en privado su autoridad patriarcal a través del control de la sexualidad de las mujeres, en el marco de una masculinidad vigorosa pero civilizada. Así, se selló un pacto patriarcal interclasista que permitió aunar esfuerzos en aras de construir una nación moderna y tolerante racialmente, fundada en los valores familiares tradicionales (Wade 2009).

Sin embargo, este mismo proyecto estaba plagado de contradicciones: mientras buscaba una mayor fluidez en las relaciones raciales pretendía ejercer un férreo control de la laxitud moral que se atribuía a los grupos racializados, mediante políticas y programas de intervención social. Y al mismo tiempo que promovía los valores de la modernidad salvaguardaba de ellos a las mujeres. Los grupos racializados, al igual que las mujeres, compartían el mismo estatus social minorizado y suscitaban las mismas sospechas, por ser considerados incompetentes para adecuarse a los mandatos de la modernidad. Así los únicos que pudieron beneficiarse totalmente de la modernidad fueron los hombres blancos heterosexuales de las clases superiores que monopolizaban las reglas del control moral y el privilegio de la honorabilidad. 
A lo largo del siglo XX se elaboraron distintas estrategias para consolidar proyectos nacionales que permitieran definir la región como una extensión de los ideales liberales y democráticos de la modernidad. En este proyecto se entretejieron medidas de regulación de las prácticas cotidianas a través del dispositivo del honor, políticas nacionales de salud pública y programas de higiene social que buscaban con determinación liberar al pueblo de la mácula de su «barbarie» original. En Brasil se hicieron múltiples tentativas para integrar a los pretos y pardos en una sociedad de clases y hacerlos encajar en la imagen de la nueva nación democrática en términos raciales (Freyre 2006 [1933]). En Ecuador también se intentó transformar las periferias de la nación habitadas por los ecuatorianos racializados mediante proyectos de desarrollo que permitieran adecuar tanto a las tierras como a su gente a la ideología del progreso y la modernidad y a los modelos de modernización y crecimiento industrial (Whitten I98I). En México, el mestizaje fue pensado como una fusión de razas que debería apuntar al blanqueamiento del país pero desafiando la superioridad europea (Aguirre Beltrán 1969). Este planteamiento fue aplicado durante todo el siglo XX como un discurso estatal suficientemente flexible pero firme en su deseo de generar una identidad mexicana desracializada y nacionalizada, apta para su pleno acceso a la modernidad. Solo a finales del siglo XX, los movimientos indígenas y negros lograron cuestionar el modelo de la nación mestiza y hacer reconocer la multiculturalidad de las sociedades latinoamericanas. Ahora bien, ¿qué trajo al repertorio de valores sexuales y de género el giro multicultural?

\section{A modo de conclusión: las paradojas del multiculturalismo neoliberal}

Desde la adopción de su nueva constitución en 199I, Colombia, al igual que otras naciones latinoamericanasfue redefinida como una nación “pluriétnica y multicultural”. A través de estas nuevas constituciones muchos países de la región buscaron resolver la ambigüedad que producía 
reconocerse y desconocerse al mismo tiempo en relación con sus orígenes americanos, europeos y africanos. Sin embargo, este reconocimiento de la multiculturalidad no significó abolir totalmente las categorías raciales en las interacciones cotidianas sino reemplazarlas gradualmente por denominaciones que hacían referencia a la etnicidad y la cultura para legitimar y normalizar las prácticas modernas del racismo, (De la Cadena 2000). En este nuevo contexto se generó una configuración social particular en la cual, como señala Peter Wade, coexisten racismo y democracia racial, en tanto fenómenos no únicamente sincrónicos sino interdependientes. (Wade 2009: 158).

Por otra parte, la respuesta a las demandas de los movimientos indígenas y de afrodescendientes ha sido muy limitada, si se la compara con la extensión de las reformas neoliberales que se han dado en el mismo periodo. Tal como lo señala Charles Hale (2004), existe una correlación entre "los gobiernos que han desarrollado las políticas más extensas de derechos indígenas y reconocimiento cultural en Latinoamérica” y los que "han promovido las reformas económicas neoliberales". Hale argumenta que como resultado de esta combinación, se ha generado una nueva forma de gobernar a los ciudadanos que él llama "el proyecto cultural del neoliberalismo" que consiste en la apertura de espacios de participación para los grupos étnicos mientras al mismo tiempo se crean límites que abortan sus aspiraciones más transformadoras”. Desde distintas perspectivas, diferentes autores (Gros 1997, Hale 2005, Wade 20I0, Viveros 20I2) coinciden en señalar que el multiculturalismo en vigor no solo no ha logrado reducir los efectos racializados de las políticas neoliberales que afectan especialmente a estos grupos étnicos sino que ha contribuido a reproducir su marginalidad social.

Si bien hay que matizar esta afirmación teniendo en cuenta las experiencias de los distintos países en términos de reconocimiento de derechos étnicos y culturales vale la pena retener la contradicción que recalca Hale al decir que el multiculturalismo neoliberal ha logrado el reconocimiento de derechos culturales, pero no el reconocimiento de las desigualdades so- 
ciales. La paradoja radica entonces en que el multiculturalismo neoliberal refuerza el racismo contra el que supuestamente lucha. A manera de ejemplo de estas contradicciones voy a referirme para terminar al caso de las clases medias negras en Colombia, que he estudiado en los últimos años. La realidad del surgimiento de una clase media negra podría ser a primera vista el efecto de la democratización de las relaciones raciales que trajo el multiculturalismo, sin embargo un análisis más detallado no permite sostenerlo. Si bien las políticas multiculturales abrieron un espacio político para las comunidades negras y para el surgimiento de una identidad étnica menos difusa que la que existía anteriormentela existencia de este pequeño grupo social ha sido fundamentalmente el resultado de su inserción en el mercado capitalista y de su constitución simbólica como un nuevo grupo de poder por parte de los medios masivos de comunicación.

En relación con el racismo, los resultados de nuestras investigaciones señalan que a pesar de que esta pequeña capa de la población negra tiene acceso al consumo de las clases medias bogotanas, en muchas oportunidades se ve obligada exhibir los códigos adecuados de clase, género y sexualidad para no sufrir las consecuencias de ser percibidos como "negras o negros”, en una sociedad que sigue haciendo equivalente pobreza, y negridad (Gil 20IO). Este comportamiento juega como un elemento protector que les permite escapar a discriminaciones raciales potencialmente más severas para la gente de piel más oscura o incluso para las personas de piel más clara que no logran encarnar adecuadamente las normas de clase y de género que están asociados a los sectores medios y superiores de la capital.

En el contexto del multiculturalismo las mujeres y hombres negros que buscan un ascenso social han de acoger los valores y comportamientos que los vuelven respetables y los alejan de los estereotipos negativos que siguen pesando sobre ellas y ellos. Las mujeres deben ser sobrias y discretas en su tono de voz, gestualidad y comportamiento social, y adecuar su presentación personal a la imagen estética de la feminidad valorada en estas clases sociales. Deben desexualizarse después de cierta edad y de haber adquirido el estatus de casadas, previniendo posibles equívocos de la vida cotidiana y 
laboral que evoquen su supuesta lubricidad "natural", uno de los prejuicios raciales más persistentes sobre la sexualidad de las mujeres negras (Viveros 2004). Por su parte, los hombres deben ser trabajadores responsables, buenos proveedores económicos y ojalá los únicos o los principales; deben moderar la expresión del gusto por los comportamientos licenciosos y tener modales de caballeros en el espacio público, para disociarse de la vulgaridad y desenfreno que se imputan a los hombres negros de sectores populares (Viveros 2002). Y no solo deben adoptar y encarnar estas normas de género, sino también las normas sexuales que señalan que las mujeres y los hombres "normales" deben ser heterosexuales y renunciar a cualquier comportamiento que ponga en duda su virilidad o feminidad. Únicamente de esta manera pueden pretender beneficiarse de los réditos sociales de la respetabilidad.

Sin embargo, las mujeres y hombres negros que desean ascender socialmente ya no pueden contentarse con asumir los valores que corresponder al ethos moderno del periodo republicano, en que la capacidad de trabajo, la conducta moderada y virtuosa, la racionalidad productiva y búsqueda de un beneficio estable y continuo les aseguraba su inserción en la Sociedad mayor. El multiculturalismo neoliberal que reconoce sus diferencias culturales, si desean afirmarlas, los acoge de forma condicional. Ellas y ellas tienen claro que este ascenso solo se va a lograr con base en su esfuerzo individual y en su capacidad de autogestionarse. Igualmente saben que están obligadas a repetir constantemente el guion social de la "blanquidad" - en el que representan un papel muy importante las normas de género y sexualidad que son a la vez, como lo señalamos anteriormente, normas de clase — , para que este estatus al que acceden tenga cierto efecto de permanencia. El éxito alcanzado por algunos solo puede sugerirle a los demás que "el camino más factible para avanzar socialmente no es la movilización colectiva, sino la perseverancia y el esfuerzo individual" (Andrews 2007:318).

En conclusión, las sociedades latinoamericanas multiculturales de hoy no son más democráticas en términos raciales que las naciones fraguadas 
por las ideologías del mestizaje ni le asignan menor importancia a la raza. Por otra parte, el neoliberalismo - como ideología del capitalismo global —, pese a su apariencia y discursividad aparentemente "neutrales", prolongó las lógicas económicas de la modernidad temprana que privilegiaban, desde una perspectiva sexista y racista, los atributos que se asociaban a un empresario "blanco", física o políticamente, sin hacer visible su lugar de privilegio (Frankemberg 2004). Las transformaciones que trajo el giro multicultural tampoco aportaron una redefinición del repertorio cultural sexuado y racializado preexistente, sino su adecuación a las nuevas estrategias de mercado y prácticas de consumo (Castells i998). Así, el mandato del blanqueamiento social en la era del multiculturalismo neoliberal ha seguido cumpliendo eficazmente su función, incluyendo a unos pocos, fortaleciendo la ideología de la meritocracia anclada en el individuo, constituyendo subjetividades que internalizan sus normas y valores sexuales y de género y difundiendo representaciones racializadas del mundo que inciden hasta en los dominios más íntimos de la vida social.

\section{Referencias bibliograficas}

AGUIRRE BELTRÁN, Gonzalo. (1969) "Oposición de raza y cultura en el pensamiento antropológico mexicano”. Revista Mexicana de Sociología, Vol. 3 I, No. I (Jan. - Mar.) pp. 5I-7I. Universidad Nacional Autónoma de México

ANDREWS, George Reid (2007). América Afro-Latina (I800-2000). Trad. Magda Lopes. São Carlos, SP: EDUFSCAR.

CASTELLS, M. (1998): "Paraísos comunales: identidad y sentido en la sociedad red", en La era de la información. Economía, sociedad y cultura. Vol. 2. El poder de la identidad. Madrid, Alianza, pp. 27-90.

CAULFIELD, Sueann (1997). El nacimiento de Mangue: La raza, la nación y la política de la prostitución en Rio de Janeiro, I850-1942, en Daniel Balderston 
y Donna. J. Guy (Comp.), Sexo y sexualidades en América Latina, Buenos Aires: Paidós, pp. 139-162.

DE LA CADENA, Marisol (2000) Indigenous mestizos: the politics of race and culture in Cuzco, 1919-199I (Durham, NC: Duke University Press).

FACUNDO NAVIA, Ángela (2006) Los padres y las madres de la patria. Representaciones médicas de las mujeres en Bogotá a comienzos del siglo veinte, en Mara Viveros, Claudia Rivera y Manuel Rodriguez (comps.) De mujeres, hombres y otras ficciones...: género y sexualidad en América Latina Bogotá: Tercer Mundo : Universidad Nacional de Colombia, Facultad de Ciencias Humanas, pp. 77-96.

FRANKENBERG, Ruth (2004). A miragem de uma branquidade não marcada, em Vron Ware (org.) Branquidade: identidade branca e multiculturalismo. Rio de Janeiro: Garamond, 2004

FREYRE, Gilberto, (2006 [1933]) Casa-Grande e Senzala. Formação da familia brasileira sob o regime da economía patriarcal, Sao Paulo: Global Editora.

GIL, Franklin. (20I0). Vivir en un mundo de blancos. Experiencias, reflexiones y representaciones de 'raza' y clase de personas negras de sectores medios en Bogotá D.C. Tesis para optar por el título de Magíster en Antropología Social. Departamento de Antropología. Universidad Nacional de Colombia.

GROS, Christian. (1997) "Indigenismo y etnicidad: el desafío neoliberal, en Antropología en la modernidad: identidades, etnicidades y movimientos sociales en Colombia. Bogotá: Instituto Colombiano de Antropología, pp. 15-60

GUY, Donna (1991). Sex and danger in Buenos Aires: prostitution, family, and nation in Argentina (Lincoln, NB: University of NebraskaPress).

HALE, Charles. (2005) Neoliberal Multiculturalism: The Remaking of Cultural Rights and racial Dominance in Central America. PoLAR. Political and Legal Antbropology Review, 28 (I): IO-28

HERING, Max (2007). Raza: Variables Históricas. En: Revista de Estudios Sociales 26

LEAL LEÓN, Claudia (2010). “Usos del concepto 'raza' en Colombia”, en Claudia Mosquera Rosero-Labbé, Agustín Laó Montes y César Rodríguez 
Garavito (comp.) Debates sobre ciudadanía y políticas raciales en las Américas negras, Bogotá: Universidad Nacional de Colombia, pp. 389-438.

MORENO FIGUEROA, Mónica. (2OI2) "Yo nunca he tenido La necesidad de nombrarme": reconociendo el racismo y el mestizaje e México", en Alicia Castellanos Guerrero, y Gisela Landázuri Benítez (coord.) Racismos y otras formas de intolerancia de Norte a Sur en América Latina, México: Universidad Autónoma Metropolitana y Juan Pablo Editor, pp. 15-49.

RODRIGUEZ, Pablo (Dir.) (2010) Historia que no cesa: La Independencia de Colombia, I780-I830. Bogotá: Universidad del Rosario.

SILVERBLATT, Irene (1987) Moon, sun, and witches: gender ideologies and class in Inca and colonial Peru (Princeton, NJ: Princeton University Press).

STOLCKE, Verena (1992). Racismo y sexualidad en la Cuba colonial. traducción de Ana Sánchez Torres. Madrid: Alianza [etc.]

VIVEROS VIGOYA, Mara y GIL HERNÁNDEZ, Franklin (2010) Género y generación en las experiencias de ascenso social de personas negras en Bogotá. Maguaré, nº 24, 2010, pp.99-130.

VIVEROS VIGOYA, Mara (2002). De quebradores y cumplidores: sobre hombres, masculinidades y relaciones de género en Colombia. Bogotá, CES, Universidad Nacional de Colombia, Fundación Ford, Profamilia Colombia.

VIVEROS VIGOYA, Mara (2004). El gobierno de la sexualidad juvenil y la gestión de las diferencias. Reflexiones a partir de un estudio de caso colombiano. Revista Colombiana de Antropología, vol. 40, enero-diciembre, pp. 155 -I 83 .

VIVEROS VIGOYA, Mara. (Coord.) (20II). Informe de la investigación Hexca Colombia, Enero 19.

VIVEROS VIGOYA, Mara (20I2). Sexuality and Desire in Racialized Contexts. In: AGGLETON, Peter; BOYCE, Paul; MOORE, Henrietta L; PARKER, Richard. (Ed.) Understanding Global Sexualities. New Frontiers. London, New York: Routledge, pp. 218-23I.

VIVEROS VIGOYA (20I3), Mara. Movilidades y desigualdades espaciales y sociales en el contexto del multiculturalismo latinoamericano. Una lectura en clave de género, en Juliana Ströbele-Gregor y Dörte Wollrad (ed.) Espacios de 
género. Buenos Aires, Nueva Sociedad/Fundación Friedrich Ebert/Adlaf, pp. I89-203.

WADE, Peter (1997). Gente negra, nación mestiza. Dinámicas de las identidades raciales en Colombia. Bogotá, Editorial Universidad de Antioquia/ ICAN / Siglo del Hombre Editores/ Ediciones Uniandes.

WADE, Peter (2008). “Debates contemporáneos sobre raza, etnicidad, género y sexualidad en las ciencias sociales, en Peter Wade, Fernando Urrea Giraldo y Mara Viveros Vigoya (editores), Raza, etnicidad y sexualidades. Ciudadania y multiculturalismo en América Latina, Bogotá: Universidad Nacional de Colombia. Facultad de Ciencias Humanas. Centro de Estudios Sociales (CES), Escuela de Estudios de Género, pp. 4I-67

WADE, Peter (2009). Race and Sexuality in Latin America. London, Pluto Press, 2009 .

WADE, Peter. (2010) “Liberalismo, raza y ciudadanía”, en Claudia Mosquera Rosero-Labbé, Agustín Laó Montes y César Rodríguez Garavito (comp.)

Debates sobre ciudadanía y politicas raciales en las Américas negras, Bogotá: Universidad Nacional de Colombia, pp. 467-489.

WHITTEN, Norman (ed.). (198I). Cultural transformations and etbnicity in modern Ecuador. Urbana: University of Illinois Press. 


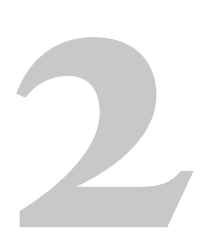

\title{
Família, modos de usar e abusar. Maternidade e deslocamentos ou ensaiando indisciplinas ${ }^{1}$
}

\author{
औ" \\ Mary Garcia Castro
}

\section{Apresentação}

Família e maternidade são temas que se entrelaçam, enredam-se e na forma de se enlaçarem anulam ou afirmam processos de emancipação feminina. É comum

${ }^{1}$ Este texto em sua versão original foi apresentado no IV SEMINÁRIO ENLAÇANDO SEXUALIDADES, organizado pela Universidade do Estado da Bahia (UNEB), sob os cuidados do Grupo de Pesquisa Enlace e do Grupo de Atuação em Defesa das Mulheres (GEDEM), na Mesa Conferência "Famílias, Modo de Usar", UNEB, Salvador, 27 a 29 de maio de 2015. 
atribuir-se à família, e em especial à mãe, se a referência são grupos na pobreza, a responsabilidade pelas trajetórias do filho ou da filha, principalmente se tais caminhos são tidos como desviantes ou turbulentos para a moral e bem-estar da sociedade dominante.

A mãe que tem o filho assassinado pela polícia, estigmatizado na imprensa como bandido, além da dor pelo filho perdido, da busca do corpo ocultado, acumula a culpa que lhe é imposta pela sociedade.

Mas a complexidade da maternidade, a carga de ser pai e mãe, principalmente quando em famílias monoparentais, desafia codificações absolutas. O rebento, que a vida arrebenta, é “o meu menino”, objeto de cuidado, que se impõe sacrifícios, gratifica. Não ao azar vem o feminismo mais discutindo cuidado, como trabalho que desestabiliza divisões entre o púbico e o privado, como ética social, respaldado por vínculos, afetos que para alguns autores empodera e para outros reproduz submissões de gênero na classe.

Nesta peça discutimos modos de valorar tal binômio família e maternidade em algumas perspectivas feministas, aterrissando ao final, por breves referências, em uma mãe que desloca a relação família e maternidade, para maternidade e sociedade, a mãe pública, figura que vem se fazendo cada vez mais presente, tirando a ética do cuidar do pequeno mundo da família, desafiando Estado, um estado de coisas, a desumanização destes tempos de barbárie. Ou seja, em termos de ensaio, texto ainda em desenvolvimento em plano de livre pensar, reflito algo sobre a mãe do considerado o "bom bandido", o morto. A mãe, da sua dor, tira coragem para brigar por tantos outros, estigmatizados como "maus bandidos", porque ainda vivos, logo marcados pelo Estado policial para morrer.

Para alguns autores no campo feminista, o processo - de maternagem, maternidade - estaria contaminado por relações sociais, simbólicas e patriarcais, que marginalizariam ou afogariam uma mulher em se fazendo, enquanto, para outras feministas, mãe, maternagem, maternidade poderiam colaborar para um poder singular das mulheres, principalmente se a família fosse esquartejada, ou seja, dela suprimida o macho reprodutor e 
se transitasse sem fronteiras, deslocando-se entre família de casa, família da rua, família mundo.

\section{Enfoques no Feminismo sobre família e maternidade ${ }^{2}$}

Michèlle Barrett e Mary McIntosh, ambas sociólogas e feministas de renome, em trabalho que marcou o campo de estudos sobre família, The Anti-social Family (1982), enfatizam que a briga quer de socialistas quer de feministas deveria ser contra a ideologia familista hegemônica que muito se identifica com uma ideologia sexista heteronormativa que marca a sociedade ocidental, contra certos tipos de configurações familiares e a exclusão de tantas outras possíveis. A questão é que são tênues as fronteiras entre instituição, legitimidade social desta e imposição de uma ideologia, assim como a desidentificação de socialistas e feministas com a crítica a um tipo histórico e social especifico de família - a família nuclear ou extensa baseada na autoridade do pai-marido e na divisão sexual do trabalho, do poder e do prazer. A crítica feminista a tal tipo de família foi confundida com uma palavra de ordem genérica: "morte à família".

Tal simplificação é rejeitada por diversos autores. Por exemplo, Chodorow e Contratto (1982) em artigo crítico às correntes feministas, negam a propriedade de posturas que consideram a mãe como toda poderosa, assim como aquelas que reduzem a mãe e a mulher a vítimas passivas. Também advertem que assim como os antifeministas tendem a culpar a mãe por tudo que acontece na trajetória dos filhos, há correntes feministas que culpam a criança ou o ter filhos por privações no ambiente de maternagem e do fazer-se sujeito mulher.

Também Barrett e McIntosh (1982) como muitas outras feministas e sociólogas recusam interpretações essencialistas sobre a família e só

\footnotetext{
2 Esta parte é adaptação de texto constante do artigo "É possível um diálogo entre a Psicanálise Winnicottiana e o Feminismo de corte Sociológico, quando o foco é gênero e família? Notas a partir de leituras cruzadas sobre maternidade - Nancy Chodorow e D. W. Winnicott". (CASTRO, 2014)
} 
debatem sobre o tema o territorializando: qual família? De quem? Em que classe? Em que cultura? Como? Representada de que forma e por quem? No interesse de quem, de quê e onde?

Pede-se, portanto, referências históricas aos nexos entre o público e o privado, dando contexto a textos e evitando o pecado original da própria sociologia, no século XIX, a busca de leis gerais.

Barrett e McIntosh (I982) relativizam determinismo contextual ao insistirem na perspectiva da heterogeneidade de apropriações de sentidos no debate sobre família por ênfase na ideologia, ou seja, no familismo, dando, portanto, espaço ao plano das representações ou das reapresentações do vivido ou da "realidade" do simbólico, tendo como referência a dinâmica interna da família e nesta a vida afetiva e a socialização.

Uma das teses de Barret e McIntosh (1982) é de que o apelo a reconhecidas propriedades da instituição família como o apoio emocional, a importância dos vínculos de parentesco, inclusive para o desenvolvimento da criança, a blindaria contra as críticas, mas o que se deveria perguntar é: por que só a família cumpriria tais papéis?

[A família] é de fato a principal agencia do cuidar, mas ao monopolizá -lo, tornou mais difícil empreender outras formas de cuidados. A família é realmente uma unidade de compartilhamento, mas exigindo partilha ao seu nível, fez com que outras relações de cuidados em outras esferas tendessem a se tornar mercenárias. É realmente um lugar de intimidade, mas privilegiando a intimidade, como restrita a parentes próximos, colabora para que o mundo exterior a ela seja frio e não amistoso. E tornou difícil de sustentar relações seguras e confiáveis em outras agências que não as formadas por parentes. Carinho, partilha e amor seriam mais generalizados se a família não reivindicasse o monopólio de tais sentimentos. (BARRET; MCINTOSH, I982, p. 82, tradução nossa) ${ }^{3}$

${ }^{3}$ It [the family] is indeed a major agency for caring, but in monopolizing care it has made it harder to undertake other forms of care. It is indeed a unit of sharing, but in demanding sharing within it has made other relations tend to become more mercenary. It is indeed a place of intimacy, but in privileging the intimacy of close kin it has made the outside world 
É focalizando o constituinte afetivo da família que as feministas vão apresentar críticas mais consensuais, já que o amor romântico e a suposta amorosidade das mulheres seriam tidos como coadjuvantes de assimetrias de poder e dependências, qualidade negativas à autonomia, inclusive emocional, das mulheres.

A ética de cuidado para algumas feministas e sociólogos se chocaria com a ética de justiça quanto à distribuição de responsabilidades. É quando muitas se questionam, mas concordam sobre a dependência afetivo emocional das crianças pequenas, sua necessidade de cuidados, o que incluiria principalmente afeto. (CASTRO; ALMEIDA; CARVALHO; MOREIRA, 20I2)

Maternidade e cuidado são temas que vem sendo revisitados por sociólogos e feministas e mesmo os que usam o conceito de patriarcado em aportes teóricos para desvendar obstáculos à realização da mulher como sujeito de direitos, desejos e sem subordinações, não se centralizam mais necessariamente na família como instituição concreta, lócus de vivencia de uma relação de parentesco ou convivência, como fonte principal daquele sistema de dominação. Gênero, família e maternidade são indagados como construções que pedem mudanças e que admitem desestabilizações e de reconstruções de sentidos. É quando algumas feministas mais investigam sobre a potencialidade da maternagem, dos laços entre filhas e mães para uma possível erosão de reproduções do patriarcado. Destaca-se socialização em gênero. (CHODOROW, 1978)

Contudo o próprio conceito de socialização pede colchetes, pois implicaria tomar um modelo estático de práticas, crenças, atitudes e valores que seriam decalcados em um ser passivo e sem autonomia, a criança, ou que seriam negados, mas também pelo mesmo processo, por transmissão vertical mono linear, impressos no objeto criança. Mas que objeto é esse?

cold and friendless, and made it harder to sustain relations of security and trust except with kin. Caring, sharing and loving would be more widespread if the family did not claim them for its own. 
É quando algumas feministas reconhecem a importância da psicanálise e se voltam para a discussão sobre subjetividades, a produção de identidades engendradas ou em se fazendo, desfazendo-se e se refazendo por aí (BARRET; MCINTOSH i982; MITCHELL, I974; CHODOROW, I978 entre outras). Mas que psicanálise?

$\mathrm{O}$ foco em subjetividades engendradas aproxima algumas feministas de Lacan e Freud, recorrendo "à lei do pai" que apelaria também para desejos e necessidades da criança - entre outras Simone de Beauvoir do Segundo Sexo é comumente citada como ilustração e para o caso da relação entre pai e filha, segundo Barrett e McIntosh (1982).

Já Mitchell (1974) insiste em aproximar o feminismo da psicanálise freudiana, considerando que é neste campo que melhor se anuncia a dinâmica do patriarcado. Já para outros, a teoria freudiana estaria baseada em uma família burguesa datada, ressaltando-se culpas e repressões sociais, o que não resistiria o passar dos séculos, e seria menos convincente quando referida à sexualidade feminina - Chodorow (1978), por exemplo.

Mas resgatando se não a criança, a relação mãe e filhos, e advogando a importância de tal díade inclusive no questionamento da "lei do pai", objeto de mais críticas que a família algumas feministas destacam o tema da maternidade. ${ }^{4}$ Outra aproximação entre sociologia, feminismo e psicanálise seria tentada, considerando a versão da psicanálise que apresentaria outro olhar sobre o conflito de Édipo e resgataria a importância da relação mãe-filho, principalmente mãe-filha.

Linha do feminismo critica a construtos da psicanálise de corte freudiano, centralidade do complexo de Édipo em todos os ciclos de maturação e interpretação sobre a mulher por inveja do pênis, recorre à perspectiva das relações objetais, com ênfase não exclusivamente em uma ética de cuidado, mas também em uma ética de justiça. Revisito com tal norte, a feminista e socióloga Nancy Chodorow (1978-tradução para o português

4 Entre essas podemos citar Nancy Chodorow (1978), Dorothy Dimenstein (1976) e Jessica Benjamin, citada em Chodorow e Contratto (1982). 
em 2006) e seu livro A reprodução da maternidade: psicanálise e a sociologia de gênero.

Reis (2008) recorre a Zeretsky para situar algumas diferenças entre Freud e Klein, autora das relações objetais que muito influenciou os escritos de Chodorow:

Tanto para Freud como para Klein o sujeito luta por conseguir certa bondade, mas para Freud a luta era kantiana e moral, enquanto para Klein era concreta e relacional. Para Freud, o superego era um imperativo categórico e despersonalizado; para Klein, se referia aos outros particularizados e concretos. Para Freud, o mundo interno estaria dominado por conflitos de autoridade; para Klein estaria dominado pela responsabilidade para com a particularidade dos outros com quem se incorre em obrigações, não em virtude de ser parte do gênero humano, como em Kant, mas porque se está em relações e circunstancias especificas. (ZARETISKY, 2003 apud REIS 2008, p. 227)

Chodorow (1978) reconhece a importância da ética do cuidado para o desenvolvimento da criança, e critica a tendência das feministas discutirem teorias sobre a maternidade sem discutir teorias sobre infância e desenvolvimento da criança. Para ela e Susan Contratto (1982, p.7I), em artigo intitulado "A fantasia da mãe perfeita": "precisamos construir teorias que reconheçam colaboração e compromisso, assim como conflitos”, mas defendem que "A fantasia da mãe perfeita tem levado a uma opressão cultural das mulheres em interesse por uma criança, cujas necessidades são também fantasiadas”.. (CHODOROW; CONTRATTO ı982, p. 72)

Chodorow (1978) expressa o reconhecimento que muitas mulheres querem de fato ser mães, mas que tendem a exageros comprometedores do seu fazer-se sujeito mulher e do desenvolvimento das crianças, freando a possibilidade de que venham a desestabilizar práticas tradicionais nas relações de gênero, como as divisões sexuais de trabalho, prazer e poder. Considera que outras modelagens de maternagem são possíveis e que as mulheres podem vir a ser mães e mulheres, mas advoga que para tanto há que começarmos sendo críticos de um discurso naturalista da maternagem. 
Aliás, discurso que viria segundo Badinter (20II) em seu livro com o sugestivo título $O$ conflito, a mulher e a mãe sendo revivido, inclusive por correntes do feminismo, o chamado "feminismo ecológico".

Para Chodorow (1978) maternidade não seria um destino, nem um instinto, nem dragão que domina o inconsciente, mas uma construção social. Ora toda construção traz em si o gérmen da sua desconstrução, mesmo que utópica. Chodorow (1978) insiste nos vínculos emocionais entre as mulheres, na díade mãe-filha, como antídoto a uma reprodução de relações patriarcais, o que é interpretado por alguns como uma busca utópica por uma sociedade sem pai e por outros como questionamento da autoridade paterna. Mas essa autora apresenta postura mais radical: e por que não uma sociedade sem mães e pais definidos pela biologia?

Contudo Chodorow (1978) é criticada por outras feministas, como Barrett e McIntosh (1982) por ter se restringido à análise da dinâmica da família e porque ao se aproximar da psicanálise, teria deixado de lado o debate que para essas autoras seria mais fecundo para o feminismo: a relação entre o privado e o público ou a estruturação da família como uma ideologia. Ideologia que não se reproduziria tão somente ao nível da família ou pelas relações na família, mas que sustenta um etbos civilizatório amparado por distintos aparatos sócio-político-culturais. Concluem Barrett e McIntosh (1982, p. 130, I59),

Precisamos não apenas de uma análise da família como instituição ou família como socialização, é preciso uma análise da situação absolutamente hegemônica da perspectiva familiar [ou familitistica] e da ideologia familiar. Assim discordamos fortemente, portanto, daqueles que argumentam que "a família” está em declínio. Temos realçado o caráter antissocial da forma presente da família, mas também o seu privilégio social que a faz como uma entidade poderosa.[...]

O que se necessita não é construir uma alternativa à família - novas formas de grupo doméstico que venham a satisfazer todas as necessidades que as famílias devem cumprir hoje. Mas urge fazer com que a família se torne menos necessária, através da construção de outras 
formas de gregarismo que venham a cumprir as necessidades das pessoas, formas menos voláteis e inadequadas do que aquelas baseadas na suposição de que 'o sangue é mais espesso que a água'.

O familismo como ideologia muito se aproxima de fundamentalismos religiosos e perversas reproduções de violências contra a homoafetividade e os trânsitos que negam a dicotomia sexo e gênero, como a Teoria Queer - mas essas são notas para outro texto.

A dependência histórico-político-cultural para os sentidos dados pela mulher à maternidade e formas de seu exercício são mais sublinhadas por autores feministas, em especial considerando esses tempos. Segundo Badinter (20II, p. 2I):

O individualismo e a busca de plenitude pessoal predispõem as futuras mães a se fazerem perguntas que elas não se faziam no passado. Uma vez que a maternidade não é mais o único modo de afirmação de uma mulher, o desejo de filhos pode entrar em conflito com outros imperativos.

A diversidade de estímulos e pulsões por vínculos familiares e o querer ser mãe não podem ser reduzidos a orientações pragmáticas ou ao "espirito de uma época”, já que estão relacionados também à micropolíticas de afetos, sendo portanto parte de relações sociais de gênero mas não somente dessas.

\section{Reflexões de Chodorow}

Chodorow (2006, p. 258) sublinha a importância do aporte psicanalítico de relações objetais para análises sobre mulher, maternidade e reprodução de construtos de gênero:

A maternidade pelas mulheres, portanto produz auto definição e capacidades psicológicas nas mulheres e reduz e inibe essas capacidades e auto definição nos homens. A primitiva experiência de serem cuidadas por mulheres produz uma fundamental estrutura de expectativas 
nas mulheres e nos homens referentes à falta de interesses separados de seus filhos e um total interesse pelo bem-estar de seus filhos. As filhas crescem, identificando-se com essas mães, e sobre as quais elas têm expectativas. Essa série de expectativas é generalizada ao pressuposto de que as mulheres naturalmente cuidam de crianças de todas as idades e à crença de que as qualidades 'maternas' das mulheres podem e devem estender-se ao trabalho não maternante que elas fazem.

Em linha similar a outras feministas referidas neste texto, como Michèle Barrett e Mary McIntosh (1982), Badinter (2011), Chodorow (1978) e Chodorow e Contratto (I982), se alinham à crítica sobre a atual organização da maternidade e ressaltam o caráter de ideologia da maternidade, considerando que este é elemento básico a sustentar um sistema de sexo-gênero, dando base para reprodução de desigualdades sexuais.

Pela ideologia da maternidade, a mulher mãe teria a obrigação de se enquadrar a uma idealizada noção do que seria uma boa mãe, sendo responsável pela trajetória de vida psicológica e, inclusive para o senso comum, material dos filhos e filhas, mesmo quando tem seu comportamento, horizontes simbólicos, liberdade de circulação e acesso a oportunidades limitados por uma sociedade pautada em uma dominação masculina: "crenças em uma super poderosa mãe sustenta um ethos cultural que culpabilizaria as mães e a fantasia da perfeição maternal”. (CHODOROW; CONTRATTO, i982, p. 55)

Essas autoras diferenciam a ideologia pró-maternidade e a forma como essa seria culturalmente fantasiada. Defendem o direito de uma mulher querer ter filhos e se sentir gratificada com tal experiência, mas rejeitam uma perspectiva essencialista, defendendo também o direito de uma mulher não querer ter filhos. Segundo Badinter (20II, p. 206):

[...] há quase três decênios acontece uma verdadeira guerra ideológica subterrânea da qual anda não se avaliam plenamente as consequências para as mulheres. A volta com toda a força do naturalismo, revalorizando o conceito gasto de instinto materno e louvando o masoquismo e o sacrifício femininos, constitui o maior perigo para 
a emancipação das mulheres e para a igualdade dos sexos. Os partidários dessa filosofia, várias vezes milenar, detêm uma arma incomparável para fazer os costumes evoluírem na direção que desejam: a culpa das mulheres.

A apologia da maternidade reforçaria a hegemonia da heteronormatidade com suas assimetrias, entrelaça-se com o familismo e com a separação entre o público e o privado. Mas a ausência de foco também na criança é reconhecida como falha nos escritos feministas sobre família e maternidade:

Feministas têm analisado suposições e preconceitos em diversas disciplinas, e o feminismo desde o início nos levou a perceber pressupostos culturais sobre gênero (por exemplo, sobre a orientação sexual) na sociedade. Mas as feministas vêm tentando construir uma teoria da maternidade sem examinar ou perceber que uma teoria da maternidade requer também uma teoria sobre a infância e sobre o desenvolvimento da criança. (CHODOROW; CONTRATTO, I982, p. 70, tradução nossa) 5

De fato, vale a crítica ao paradoxo de correntes feministas que sublinhando o caráter relacional de gênero, ou seja, como a mulher na família se autoconstrói ou se autoidentifica na relação com o outro, pelo outro, omitem que a díade mãe e filho, também envolve relações sociais, simbólicas e de afeto que ao mesmo tempo em que a autoconstrói - como o ser mãe, por exemplo - se projeta no outro, no caso a criança, que também se autoconstruiria nessa relação. No afã de desconstruir estereótipos que atariam o destino da mulher ao de ser mãe, a potencialidade da relação mãe-filho tanto para a mãe como para o filho, inclusive para a subversão

\footnotetext{
${ }^{5}$ Feminists have analyzed assumptions and biases in various disciplines, and feminism early on led us to notice cultural assumptions about gender (e.g., about sexual orientation) in society. But feminists have been trying to build a theory of mothering without examining or noticing that a theory of mothering requires a theory of childhood and child development as well.
} 
da ordem patriarcal de gênero e entre gerações, foi pouco explorada nos escritos feministas, mais preocupados com a "tirania" da maternidade.

\title{
Algumas notas sobre Brasil hoje: reflexões sobre a maternidade como ética social do cuidado de muitos
}

\author{
A história das famílias no Brasil não é homogênea. Hoje, no Brasil, por \\ distintos processos históricos a família viria se diversificando. Segundo os \\ demógrafos Alves e Cavenaghi (2013): ${ }^{6}$
}

De modo geral, pode-se afirmar que o modelo hegemônico de família nuclear era formado por um homem e uma mulher que se uniam em um matrimônio por toda a vida e praticavam sexo com finalidade generativa. Esse modelo de família tinha como base o casal heterossexual, ele mais alto e um pouco mais velho, com maior escolaridade, já com um emprego ou independência financeira e ela mais baixa, mais jovem, com menor escolaridade e voltada para a vida privada de dona de casa ou com emprego extra doméstico com flexibilidade e tempo parcial. Esse modelo de família trazia embutida uma forte desigualdade de gênero. A menor autonomia das mulheres na família era geralmente reforçada pela desigualdade social, em especial pela baixa taxa de atividade laboral e pela segregação no mercado de trabalho. $\mathrm{O}$ menor poder, a autoridade e o prestígio feminino decorriam da desigualdade de acesso e de controle sobre os diversos recursos econômicos, sociais e culturais. Contudo, esta 'família padrão' começou a ruir na mesma época do fim da padronização fordista de produção, ou seja, com a revolução sexual dos anos de 1960 , com a disponibilidade de métodos contraceptivos, a entrada crescente da mulher no mercado de trabalho, a reversão do hiato de gênero na educação e a aceitação mais ampla de novos arranjos familiares. Cresceu o número de domicílios comandados por mulheres. Em grande parte, isso se deve ao processo

${ }^{6}$ IHU On-Line - "Em que consiste "a complexidade e a diversidade das relações familiares do Brasil contemporâneo?" Disponível em: <http://www.ihu.unisinos.br/entrevistas/515013censo-2010-uma-famlia-plural-complexa-e-diversa>. Acesso em: 20 maio 2014. 
de empoderamento feminino, mas, em outros casos, a chefia feminina é decorrência da ausência do cônjuge e da falta de responsabilização dos pais (homens) com os filhos.

O aumento da carga de muitas mulheres no Brasil com trabalhos no mercado, sem necessariamente ter uma menor carga de trabalhos domésticos viria se ampliando, assim como no último censo, de 2010 se registra que de cada dez famílias, três são "chefiadas" por mulheres, sendo que a maioria se concentra em situações de pobreza. Nesse censo se visibilizou quantitativamente os casais chefiados por pessoa do mesmo sexo que o/a conjugue são 60 mil, sendo que 53,8\% são formados por mulheres.

Outro tipo de família seria a poliafetiva, ${ }^{7}$ sem registro extensivo oficial. Tal quadro sobre a variedade de famílias no Brasil levanta algumas questões: as mães (biológicas e sociais) em tão diversas situações necessitariam de que condições para serem "mães suficientemente boas"? Quem seria a pessoa mãe em cada tipo de família, considerando a pluralidade e diversidade de sua composição?

A leitura de conflitos na equação mãe e mulher, não desata o nó entre gênero e geração no âmbito da família. Mas se o interesse maior é por relacionar ética de cuidado com ética de justiça, reconhecendo características e necessidades tanto dos bebês, quanto das crianças e das mães, e por relações sociais mais democráticas e não orientadas por hierarquias coercitivas, precisamos mais questionar nossos portos seguros se ainda não

7 "As famílias poli afetivas se referem aos arranjos familiares cujo núcleo não é monogâmico. São os 'casais de 3' ou o 'casal de n pessoas'. Pode ser um arranjo formado por um homem e duas mulheres, uma mulher e dois homens (Uma Dona Flor de verdade) ou qualquer outro tipo de arranjo envolvendo mais de duas pessoas no núcleo familiar. Mas o censo não levantou múltiplos relacionamentos. A história mostra que a poligamia e a poliandria sempre existiram de forma mais ou menos velada. A novidade agora é que estes tipos de arranjos estão sendo visibilizados e estão sendo objeto de busca de base legal para serem reconhecidos na legislação brasileira. Existem, inclusive, as famílias poliafetivas cujos membros possuem poli orientação sexual." DINIZ ALVES e CAVENAGHI-(IN http://www.ihu. unisinos.br/entrevistas/515013-censo-2010-uma-famlia-plural-complexa-e-diversa) Acesso em: 20 maio 2014. 
por diálogos, por tentativas de compreender o outro, indagar sobre nosso olhar sobre o outro, o outro conhecimento e assim quem sabe sair da zona de conforto de tolerâncias disciplinares. Mas vem se visibilizando um outro tipo de mãe, a mãe de todos, que não faz parte de estatísticas disponíveis, ou seja, a que assume uma maternidade simbólica, tornando-se mãe de muitos.

Essa mãe, aceita a tese da maternidade como uma construção social, com significados históricos específicos, nuances culturais e com diversidades de vivencias e que o cumprimento de expectativas de tal construção se redefine por limites na classe. Esses são vetores epistemológicos bem discutidos por autores como Badinter (1985) e Chodorow (1990). Mas e as mães que expandem sua proteção para a defesa de muitos?

\section{Deslocamentos: as mães públicas}

Alinho-me ao acervo de reflexões sobre as vulnerabilizações sociais das mulheres pobres mães, muitas chefas de família em unidades monoparentais; sobre a injustiça social das cobranças que lhes são feitas para serem cuidadoras, educadoras de seus filhos, sem considerar que são geralmente as únicas provedoras, e também como muitos pesquisadores, ressalto, o comum sentimento de culpa delas pelas trajetórias dos filhos.

Mas falta explorar mais as racionalizações dessas mulheres, mães na pobreza, as gratificações com o cuidar, em especial quando se rompe as dicotomias entre o público e o doméstico; e a ideia mistificada de maternagem como avessa à sexualidade, ao agito da libido. Quando se tira a maternidade do campo do sagrado e dos estereótipos e se a seculariza e se busca sentidos para as mulheres, a diversidade desafia generalizações.

Muitas se realizam em cuidados dos filhos para se sentir sujeitos; erotizam algumas o sacrifício e outras se apegam à cria inclusive para escapar de ecos de patriarcalismos, violências domésticas, o domínio do homem marido, do homem patrão, mesmo que em muitos casos caiam na armadilha do patriarca filho, do patriarca Igreja, do patriarca partido, do patriarca patrão. 
É por aí que quero começar a refletir sobre o caso das mães públicas, tendo como foco subliminar aquelas que se lançam na defesa dos seus e dos pares dos seus, em movimentos sociais por direitos humanos, decolando de uma sororidade de mulheres, mães feridas. Mobilização em que pais, homens "companheiros" ou "cônjuges" são pouco referidos. Narrativas sobre engajamentos com a coisa pública, como a busca do corpo do filho morto, a justiça pelo assassinado legitimado pelo Estado, por sua polícia e outras mobilizações coletivas, misturam dor e o prazer de se descobrir sujeito, com poderes que se estimulados por maternagem aos seus se multiplicam, se ampliam, desterritorializando fronteiras entre o público e o privado e, muitas vezes, compensando traumas de marcas que vêm do doméstico, de relações familiares de violências e subordinações.

Pensando Brasil hoje, cito as Mães de Acari, que por quase 15 anos gritaram pelos corpos dos filhos, depois da chacina de Acari, em 2006, quando II jovens marcados como bandidos, foram sequestrados, assassinados e sumidos por forças policiais, no Rio. Elas mobilizaram a opinião pública nacional e estrangeira a princípio pelo direito de enterrar os corpos de seus filhos. Se como Antígona, da tragédia de Sófocles, aquelas Mães do Acari, pagando inclusive uma das II com a vida, já que assassinada, rebelaram-se contra a lei humana, dos poderosos, da violência assassina da polícia e se alinharam a uma lei sagrada, de dar sepultura a corpos, as Mães de Acari diferentemente de Antígona não se suicidaram, emparedando-se em sua dor individualizada. Desencadearam um movimento de direitos humanos que se multiplicou por várias entidades.

Hoje são vários os movimentos de mães contra "o terrorismo de Estado” (expressão em publicação das Mães de Maio), a violência policial nas periferias. Entre outros movimentos contemporâneos, cito as Mães de Maio, as Mães de Copacabana, as Mães do Rio. Mães públicas, mães de muitos. ${ }^{8}$ Em Salvador, as mães dos jovens barbaramente assassinados pela

\footnotetext{
${ }^{8}$ Ver em Nobre (2005) sobre as mães de Acarí; e em Carvalho (2014) a autobiografia de uma mãe que vem lutando contra violências policiais em favelas no Rio de Janeiro. Deize
} 
polícia no Cabula - final de abril de 2015 - vêm desencadeando, através de movimentos sociais, protestos sobre genocídio de jovens negros.

\section{Ensaiando indisciplinas, mães se deslocando}

Mais do que decolar de pesquisas acabadas, compartilho reflexões um tanto iconoclastas, entrelaçando maternidade, sexualidade e participação política. São ideias em movimento, uma bricolagem desenganchada, um ensaio. Aquele tipo de discurso, que segundo Adorno, evoca "liberdade de espírito”. Para Adorno (1986, p. I69, grifo nosso)

O ensaio não começa com Adão e Eva, mas com aquilo de que se quer falar; diz o que lhe ocorre; termina onde ele mesmo acha que acabou e onde nada mais resta a dizer [acrescento, naquele momento do fazer cognitivo]... Seus conceitos não se constroem a partir de algo primeiro nem se fecham em algo último.

O tema mãe, maternidade, em diferentes disciplinas do conhecimento, tende a promiscuidade entre a razão, ou modelagens sobre razão e a emoção, ou chamadas sobre tal dimensão anímica, o que é bom, pois a primeira indisciplina no debate sobre a mãe deveria ser sair dos binarismos: subjetividade $\mathrm{x}$ objetividade; natureza $\mathrm{x}$ cultura; individuo $\mathrm{x}$ sociedade; mãe santa x a mãe "puta que o pariu", ou seja, a primeira é a nossa e essa a do outro, como por exemplo, o juiz de futebol.

A história é rica em casos símbolos, quando mãe na arena pública, fundiram o perfil de cuidadoras dos seus com o de cuidadoras de muitos, por ativismo político ou por enfrentamento a poderes de Estado, tiranias, violências institucionalizadas.

Carvalho é mãe de André, que aos 17 anos foi barbaramente espancado e assassinado em 31 de dezembro de 2007, no interior do DEGASE, entidade de tutelagem de jovens menores, por agentes dessa instituição, ironicamente criada para "reeducação e proteção de menores". Deize tem sido uma liderança reconhecida nas lutas por direitos humanos dos jovens periféricos, contra violências do Estado nas periferias. 
Na literatura clássica, é emblemático o romance $A$ Mãe, de Máximo Gorki, escrito em I907. A Mãe, logo nas primeiras páginas, é descrita como uma mulher "alta, ligeiramente curvada: o seu corpo quebrado pela labuta incessante e os murros do homem (o marido). Movia-se sem ruído, um pouco de lado, como se temesse sempre chocar com qualquer coisa”. (GORKI, 200o, p. 20)

O marido alcoólatra morre em um acidente, a mãe continua calada a cuidar de Pavel, o filho. Pavel, operário, envolve-se com as lutas socialistas contra o Tsarismo, a mãe se choca com a perspectiva ateísta do filho e com os modos de seus amigos, mas por admiração e para proteger seu filho vai se envolvendo, escuta, aprende a ler, participa de reuniões. Já no meio do romance a mãe, após ter o filho preso, contrabandeia panfletos revolucionários na fábrica. A polícia russa não desconfia, é apena uma velhinha, a mãe. No adiantado do romance, a mãe é também referida pelos companheiros do filho, como "a camarada", fala, opina e tem voz própria. A causa do filho é apropriada, mas por cores próprias. A mãe é socialista, fala contra injustiça e firme defende na célula que gosta e admira Jesus Cristo. Nas páginas finais, com o filho deportado para a Sibéria e muitos de seus amigos presos ou mortos, ela dialoga com uma amiga: "E como podemos ficar de lado quando amamos um, quando outro nos é querido e tememos por todos eles... Como podemos ficar de lado?” Observa Gorki:

Semivestida, ficou um instante pensativa no meio do quarto. Parecia-lhe que já não era ela, aquela que tanto se havia inquietado e afligido pelo filho, que vivera com o único pensamento de conservá-lo são e salvo; essa mulher já não existia, tinha-se afastado, partido para muito longe, não se sabe para onde, tinha-se consumido, talvez, no fogo das emoções, e desse modo a sua alma encontrava-se agora aliviada, uma nova força regenerava-lhe o coração. (GORKI, 2000, p. 437)

Referindo-se à participação dos anarquistas na historia do movimento operário no Brasil, Margareth Rago (1987), em seu livro com o sugestivo título Do cabaré ao lar: a utopia da cidade disciplinar, Brasil I890-I930, observa 
que apesar da forte presença feminina no operariado têxtil e da agenda emancipadora dos anarquistas, as alternativas de ocupações para as mulheres costumavam excluir cargos de chefia.

As fábricas, segundo Rago, eram comparadas a "lupanares” e as trabalhadoras consideradas como vítimas do capital e muito raramente como trabalhadoras que também resistiam. Eram tidas pelos companheiros militantes como "menos combativas", "maquinas inconscientes". (RAGO, I987, p. 66) Mesmo no discurso operário do inicio do século a proteção da trabalhadora era principalmente modelada por visão dicotômica, ser mãe ou ser trabalhadora no mercado, privilegiando-se a projeção da mulher para o ser mãe, ser a educadora. Rago adverte que a historia, mesmo das classes operarias, é contada por homens que representam as mulheres como mães, não como mulheres e mães e mulheres em rebelião, em buscas.

A contradição entre o público e o privado e neste do exercício da maternidade seria mais acentuado quando a referência são as chamadas "prostitutas", tanto no discurso médico como no criminológico do final do século XIX.

Mesmo entre os anarquistas era difícil associar debates sobre direito a ser ou não mãe, projeto de amor livre, emancipação da mulher, relações afetivas e moral sexual. Segundo Rago (1987, p. 96):

Se é possível perceber no conjunto dos textos libertários, uma representação masculina da mulher, que a torna símbolo da maternidade, da passividade e da fragilidade, a esta se opõe, uma outra construção contestadora de valores dominantes. Partindo de vozes femininas no interior dos anarquistas, propõe-se a emancipação da mulher de todas as classes sociais dos papeis que lhe são atribuídos socialmente. Ao lado da tradicional representação da mulher submissa emerge outra figura feminina, simbolizada pela combatividade, independência, força, figura que luta pela transformação de sua realidade cotidiana, tanto a partir da própria presença dessas ativistas como por suas projeções. 
Insisto, tendo Rago (1987) como referência, mesmo em escritos da destacada escritora de tendências anarquistas Maria Lacerda Moura, de I932, a tônica subjacente é da departamentalização: mulher não "nasceu exclusivamente para ser mãe, para o lar, para brincar com o homem, para diverti-lo”. (MOURA, 1932 apud RAGO, 1987, p. 97)

Não há debates sobre casos híbridos, entrelaçados, ou da possibilidade ou não de combinações, como entre o ser mãe e ser tantas outras personagens; a possibilidade da mulher ser um eu múltiplo e total, o que de fato, ao que parece, só é possível, tese que ensaio, quando conseguirmos escapar de generalizações, mistificações tanto do ser mãe como do ser mulher emancipada por modelagem de mulher-homem, e pela recusa da separação entre sexualidade e maternidade. Uma provocação: tudo que é fonte de prazer se move pelo erótico, mobiliza emoções.

Outra autora, de orientação anarquista, Josefina Bertacchi, no periódico Terra Livre em ı9ıo mais avança nessa linha e se refere a um modelo de equilíbrio, "a mulher nem patroa, nem escrava, nem feminina, nem angélica, nem asséptica, nem messalina”. (RAGO, i987, p. I02)

Mas reconhece Margareth Rago que tal utopia não se embasa em possibilidades decoladas de vivencias, "o ideal feminino que aparece nos textos anarquistas é delineado difusamente”. (RAGO, 1987, p. IO2)

Ainda que haja referências no ideário anarquista, à recusa do casamento monogâmico e menções a novas formas de relacionamento afetivo, passa-se ao largo de nexos entre tais indisciplinas do normativo, e questões sobre mulher e maternidade, maternidade e cuidados, e, insisto, possibilidade de trânsitos entre o público/político e o privado/afeto pela mulher/mãe. A saída mais comum é a reivindicação de famílias heteronormativas constituídas por outras organizações de parentalidade, sem divisões sexuais e assimetrias de relações entre os sexos. Os casos das famílias monoparentais com a mulher mãe, sendo a pessoa de referência da família não são contemplados, se não se nomeia como o patriarca a ser questionado, o Estado.

Por outro lado, defendo que as mães que potencializam a maternidade como estímulo para se jogar em lutas coletivas, e em movimentos sociais 
de várias ordens, mesmo que estejam saindo do privado, e se realizando como mulheres no público, elas são referidas e têm suas histórias contadas como mães, agora como mães de muitos. Conhecemos suas histórias como militantes, como mães e nada sobre como foram ou são mulheres, sujeitos de desejos em corpos por hétero e/ou homoafetividades. Romperam com a conceituação disciplinar da mãe, como domínio do privado, mas não com o disciplinamento da mãe, com sua alter representação como mulheres assexuadas.

No Brasil contemporâneo os movimentos sociais por direitos humanos que têm mulheres mães como protagonistas não somente rompem com a divisão público/privado, como também com as dicotomias entre subjetividades, desejos, afetos e economia política.

De fato a chamada economia de cuidados entrelaça a mãe individual com a mãe "societal", a mãe moral, a mãe do seu filho, sua propriedade, o eu estendido, parte de mim, útero expandido com a responsabilidade ética da alteridade por identificações, com aqueles que são pares dos filhos idos, geralmente lhes tirado por morte matada, os que pertencem à classe, a raça de seus filhos. Tais mães estão em vários capítulos da história do Brasil. Como na Ditadura Militar, quando muito aprendi em participação no Movimento Feminino pela Anistia (MFA).

Confesso que me aproximei do MFA torcendo o nariz. Foi "tarefa" política. Com tanta frente para se estar contra a Ditadura, ficar tomando chá em reuniões em mansões no Flamengo, ir a entrevistas com autoridades religiosas, com um monte de mães burguesas, chorosas. Mas tais preconceitos se desfizeram com a convivência com as mulheres, as mães do MFA.

Aprendi muito com as mulheres pela anistia. Mães burguesas, mães engajadas em partidos de várias tendências de centro-esquerda, mães de muitas caras, mas todas mães por justiça. Lembro-me de uma história que corria no MFA e que nos estimulava, o caso de Zuzú Angel. Contaramme o seguinte diálogo, que nem sei se houve, entra ela e o General Geisel: 
- 'Por que a Sra. continua insistindo com tanta algazarra, querendo saber o que passou com seu filbo se já declarou que sabe que ele foi morto por militares?' Teria perguntado irritado o General Geisel para Zuzu Angel, quando ela rompendo esquema de segurança entregou a Fimmy Carter, ao lado do general, uma carta denúncia sobre as torturas e desaparecimentos no Brasil e o caso de seu filho, Stuart Angel. E ela teria respondido:

'Porque perdi um filbo, mas tenho muito, todos jovens desparecidos, sequestrados, torturados pela ditadura são meus filbos, luto e grito por eles.9 (Informação verbal).

Ora, o caso de mães que lutam no público, em vozes únicas ou com muitas, fragiliza a ideia de que ser mãe é dimensão de vida que se realiza no doméstico, é coisa íntima, instintual, natural que se sustenta por laços de imanência e de transcendência, mas de um eu com uma parte de um outro eu que é meu, ou assim considerado.

Defendo que outra subversão é anunciada por mães que se engajam em mobilizações coletivas, decolando da maternidade, o que desafia o disciplinamento ou saberes competentes quando reduzem a mãe à família consanguínea ou de parentesco.

Concordo com Badinter (20II) quando ela alerta sobre contradições entre a mulher e a mãe, e como a construção da maternidade tende a obstaculizar a realização do ser mulher por outros parâmetros que não o da maternidade, principalmente quando o Estado não socializa serviços e os homens não renunciam alguns de seus privilégios em relações de gênero.

\footnotetext{
9 Zuzu Angel, (Curvelo, 5 de junho de 1921 - Rio de Janeiro, 14 de abril de 1976) foi uma estilista brasileira, mãe do militante político Stuart Angel Jones e da jornalista Hildegard Angel. Personagem notória do Brasil da época da ditadura militar, ficou conhecida nacional e internacionalmente não apenas por seu trabalho inovador como estilista de moda mas também por sua procura pelo filho, militante de organizações extremistas, assassinado pelo governo e transformado em desaparecido político, em que enfrentou as autoridades da época e levou sua busca a se tornar conhecida no exterior. Disponível em: < http:// pt.wikipedia.org/wiki/Zuzu_Angel>. Acesso em: 12 out. 2014
} 
Contudo, nos debates em ciências humanas e em feminismos sobre mãe, no plano do impasse entre mulher e mãe pouco se avança sobre sexualidade e as referencias a tal entrelace tendem a outra culpabilização: as mulheres estariam abdicando da maternidade por conta de um individualismo hedonista, priorizando prazeres, separando sexualidade de reprodução.

A maternidade se para algumas correntes "psi” é um tipo de realização da sexualidade feminina, no conhecimento de senso comum, fora os casos tidos como perversão, mãe é sagrada, assim se dessexualiza a mulher. De fato uma das mães mais famosas da história não pariu por processo de fecundação natural, não se fez referência se no processo de fecundação do filho houve um coito e um orgasmo.

O entrelace da maternidade com vivências e sentidos de sexualidades pede mais ousadia epistemológica.

Mas a indisciplina que mais me estimula neste ensaio é outra: a tese de que a mãe "societal”, aquela que se lança no público em um momento por um estímulo de defesa do privado, dos seus, comporta tanto a reprodução da mãe como mulher assexuada, da que transfere energias por frustrações, violências nas relações de gênero, como um outro tipo de mãe, mulhermãe em processo, que se realiza como sujeito político, o que mistura maternidade e o se jogar como mãe e mulher no público, indisciplina normativa e de difícil realização.

\section{PS:}

Em I850, aproximadamente, escreveu Gonçalves Dias, como parte do poema "A Canção do Tamoio":

E há mães nessas tabas,

Querendo caladas

Os filhos criados

$\mathrm{Na}$ lei do terror;

Teu nome lhes diga, 
Que a gente inimiga

Talvez não escute

Sem pranto, sem dor!

Hoje já são muitas as mães que gritam contra o terror e elas mesmas dizem o seu nome, ou são lembradas em versos e cantos.

Emi977, Chico Buarque e Milton Nascimento escrevem a canção "Angélica”, em homenagem a mãe Zuzú Angel:

Quem é essa mulher

Que canta sempre esse estribilho?

Só queria embalar meu filho

Que mora na escuridão do mar.

Quem é essa mulher

Que canta sempre esse lamento?

Só queria lembrar o tormento

Que fez o meu filho suspirar.

Quem é essa mulher

Que canta sempre o mesmo arranjo?

Só queria agasalhar meu anjo

E deixar seu corpo descansar.

Quem é essa mulher

Que canta como dobra um sino?

Queria cantar por meu menino

Que ele já não pode mais cantar

Quem é essa mulher

Que canta sempre esse estribilho?

Só queria embalar meu filho

Que mora na escuridão do mar. 


\section{Referências}

ADORNO, T. W. O ensaio como forma. In: COHN, G. (Org.) Theodor W. Adorno, São Paulo: Ática, 1986. p. I67-187.

BADINTER, E. O conflito a mulber e a mãe. Rio de Janeiro: Record, 20 II.

BARRET, M.; MCINTOSH, M. The anti-social family. London: Verso, 1982.

CARVALHO, D. Vencendo as adversidades. Autobiografia de Deize Carvalho. Rio de Janeiro: [s. n.], 20I4. (Coleção Nós por Nós, Movimento Mães de Maio e Rede de Comunidades e Movimento Contra a Violência).

CASTRO, M. G. É possível um diálogo entre a Psicanálise Winnicottiana e o Feminismo de corte Sociológico, quando o foco é gênero e família? Notas a partir de leituras cruzadas sobre maternidade - Nancy Chodorow e D. W. Winnicott. Revista Diálogos Possiveis, Revista da Faculdade Social da Babia, Salvador, Ano I3, n. 2, p. 26, jul./dez. 2014.

CASTRO, M.G.; ALMEIDA CARVALHO, A. M. e MOREIRA, L. V. de C. Dinâmica familiar do cuidado: afetos, imaginário e envolvimento dos pais na atenção aos filhos. Salvador: EDUFBA, 2012.

CHODOROW, N. The Reproduction of Mothering. Psychoanalysis and the Sociology of Gender, Berkeley. Berkeley: University of California Press, 1978.

CHODOROW, N. Psicanálise da maternidade, uma crítica à Freud, a partir da mulber. Rio de Janeiro: Rosa dos Tempos, 2002.

CHODOROW, N.; CONTRATTO, S. The fantasy of the perfect mother. In: THORNE, B.; YALOM, M. (Ed.). Retbinking the family. Some Feminist Questions, New York: Longman, 1982. p. 54-75.

DINIZ ALVEZ, J. E.; CAVENAGHI, S. Entrevista sobre o Censo 20 Io. Uma família plural, complexa e diversa. 20Io. Disponível em: <http://www. ihu.unisinos.br/entrevistas/515013-censo-2010-uma-famlia-plural-omplexaediversa>. Acesso em: 20 maio 2014

DINNERSTEIN, D. The Mermaid and the Minotaur. New York: Harper \& Row, 1976.

GORKI, M. A mãe. São Paulo: Expressão Popular, 2000.

MITCHELL, J. Psychoanalysis and feminism. New York: Pantheon Books, 1974. 
NOBRE, C. Uma bistória de protagonismo social. Mães de Acari. Rio de Janeiro: PUC Rio, 2005.

PATEMAN, C. The sexual contract. Stanford: Stanford University Press, 1988.

RAGO, M. Do cabaré ao lar. A utopia da cidade disciplinar. Brasil I89o-I830. 2. ed. Rio de Janeiro: Paz e Terra, 1987.

REIS, A. R. Nancy Chodorow: não se nasce mãe. In: FERREIRA, S. L. (Org.); ALVES, I. I. D. (Org.); COSTA, A. A. A. (Org.). Construindo interdisciplinaridades: estudos de gênero na Bahia. Salvador: Núcleo de Estudos Interdisciplinares sobre a Mulher, 2008. p. 219-235. 


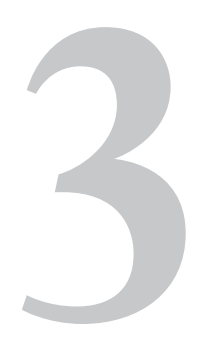

\title{
Por uma microfísica do saber:
} os contornos da família

\author{
ฟNo \\ Prof. Dr. Fosé Euclimar Xavier de Menezes \\ Fernanda Andrade Leal
}

Que estatuto possui o problema da família na obra de Michel Foucault, considerando que, do ponto de vista metodológico, o seu discurso não contempla diretamente este objeto? A comunidade dos estudiosos que se acerca da letra foucaultiana acorda em reconhecê-lo como um autor que privilegia as formas de subjetivação. (VEYNE, I982; GIRAD, I989; TRONCA, I987) Quer dizer, Foucault debate de modo objetivo sobre um tema que perpassa necessariamente os conteúdos sobre a família: o sujeito, a afirmação de sua identidade, a relação que estabelece com os seus pares, os conflitos inerentes a esta 
relação que inflexionam e influenciam as formas de subjetivação. (HAN, I989; FONSECA, 1995)

Desse modo, se a família não é o alvo direto de seu foco e de seu tratamento, o é ao menos transversalmente. Em outros termos, este objeto é capturado pelas teias discursivas do autor quando o seu olhar contempla e atravessa o sujeito e as tramas que inflexionam a sua constituição.

Um outro elemento que desperta o olhar do leitor é o fato de que, a rigor, em todos os textos do autor de História da sexualidade (FOUCAULT, I985) estejam reunidos os discursos derivados de múltiplas ciências do homem, seja no uso singular que Foucault faz de alguns conceitos, seja na critica que o autor dirige aos resultados que tais saberes esboçam nas suas investigações acerca do humano. Para o bem da clareza, tendo sob o seu olhar as figuras do louco, do perverso, do presidiário, do educando, etc., Foucault arrola os saberes que se apropriaram destes objetos, a saber, psicologia, psiquiatria, medicina, psicanálise, direito, pedagogia, etc. Este fato metodológico, precisamente, o recurso de convidar múltiplas disciplinas para o debate em torno de determinados objetos influencia a construção de um olhar acrisolador que recua para detrás do saber que discursa sobre o objeto. Portanto, não se trata de investigar as verdades sobre o objeto, derivadas de aplicações metodológicas determinadas por uma dada ciência, mas sim de inquirir os modos pelos quais tais ciências elaboram as verdades imputadas ao objeto mirado em suas lentes. De todo modo, o procedimento foucaultiano é a um só tempo crítico e multidisciplinar, dadas a extensão, a complexidade, a verticalidade e as perspectivas reunidas pelo autor em suas análises.

Enfim, Foucault constrói um discurso fino que propicia antever a modelagem realizada pelo saber e pelo poder sobre o objeto bomem. Se existe consistência no discurso que se erige sobre o sujeito humano e seu meio, bem como sobre a família na qual ele se insere, tal consistência não advém, com exclusividade, da metodologia aplicada pelos saberes na investigação de seus objetos. A esse delírio onipotente Foucault recusa. $\mathrm{O}$ que suas reflexões encaminham é a construção de um olhar que suspeita não do homem 
ou da família diretamente, mas dos discursos dos saberes que se pretendem construtores das redes conceituais que se apossam desses "objetos”.

Portanto, não faz qualquer sentido indagar acerca do significado que determinada categoria como a familia possui em seu discurso. O que aí é significante é questionar como o seu pensamento acrisolador propõe analisar os resultados que advêm do uso que as ciências humanas realizam em torno deste elemento. Foucault rejeita qualquer que seja o empreendimento epistemológico quando se trata de examinar a elaboração dos saberes e dos seus produtos, convocando-nos para uma tarefa bem mais complexa e, a seu ver, bem mais producente. Ele nos convida a reconstituir uma arqueologia e uma genealogia das ciências humanas. Como elas elaboram as verdades sobre o sujeito e sobre a família? Eis a questão que mais interessa à Foucault.

Esse é o ponto de partida mediante o qual aqui se propõe a leitura pontual da introdução do primeiro volume de História da sexualidade. Qual é a interlocução que Foucault constitui, com quem realiza o seu debate, considerando o cenário sobre o qual o texto se descortina, realizando uma discussão sobre os modos de tratamento da sexualidade na história? Quais dos saberes que se acercam do homem articulam tal discurso? Na abertura do texto, Foucault simula estar de acordo com o diagnóstico das ciências humanas acerca de nossa identidade, pequenos burgueses que somos; simula assentir que a orientação ético-moral burguesa rege a nossa conduta vitoriana; simula consentir que sejamos assujeitados a uma ordem instaurada no século XIX, ordem esta que cataloga, controla, determina como usamos ou não o nosso corpo.

Contudo, não é o que as ciências humanas dizem o que mais interessa ao autor. Não é o conteúdo constitutivo dos enunciados que mais chama a sua atenção. Bem antes, é o modo como esse discurso é construído que interessa. As ciências humanas estabeleceram que, a partir do século XVIII, tenhamos perdido uma tolerância para com as condutas ilícitas relativamente ao sexo, para as quais todos tendemos. Instauramos, com o vitorioso regime, um modo de ser mais comedido, como contraponto 
ao tempo imediatamente anterior, no qual vigorava uma tolerância bem maior aos arroubos de nossa volúpia. Uma normatividade rigorosa, um procedimento mais comedido e controlado para com a nossa sexualidade se tornou o instrumento poderoso de codificação das condutas. É neste ambiente que surge a primeira referência à família:

\begin{abstract}
A sexualidade é, então, cuidadosamente encerrada. Muda-se para dentro de casa. A família conjugal a confisca. E absorve-a, inteiramente, na seriedade da função de reproduzir. Em torno do sexo, se cala. O casal, legítimo e procriador, dita a lei. Impõe-se como modelo, faz reinar a norma, detém a verdade, guarda o direito de falar, reservando-se o principio do segredo. No espaço social, como no coração da moradia, um único lugar de sexualidade reconhecida, mas utilitário e fecundo: o quarto dos pais. (FOUCAULT, i985, p. 9-Io)
\end{abstract}

Vale sopesar o que está sendo dito. O estilo é característico de Foucault: barroco, isto é, as coisas são apresentadas sinuosamente, usando os discursos de um modo flexível na modelagem de uma outra hermenêutica. Foucault não pretende conferir se o que é dito tem sustentação ou não. É quase pacífico aceitar que o regime vitoriano instaurou um molde comportamental negativo, prescritivo, regulamentador, burocrático, funcionalista, determinista em relação à sexualidade. Tal molde prescreve e proíbe. E é exatamente isso que Foucault vai vislumbrar. Como se diz na língua de Foucault, o on dit, sustentado genericamente à moda do disse me disse, instaura, com a Rainha Vitória todo o procedimento burguês relativo à intimidade e investe na direção repressiva. O que fazemos com os nossos corpos parece ser direcionado por um dever, quase que anulando os ditames do desejo. Esse cede lugar aos imperativos enrijecidos daquele.

Não é estranho que seja justamente nesse período que vemos nascer a ciência psicanalítica. $O$ estudo da sexualidade torna-se nessa época, na Europa e nos Estados Unidos, a grande questão do século seguinte e a histeria parecia ser a peça principal. (ROUDINESCO, 20I4, p. 70) O que justifica, aqui, isolarmos o saber psicanalítico dessa cadeia de discursos dos 
saberes sobre os quais se descortinam as indagações e críticas de Foucault. Como a psicanálise elabora as verdades sobre o sujeito e sobre a família? Eis a questão que mais interessa nesse debate. O objetivo é conferir o alcance epistemológico do uso foucaultiano da categoria família.

No seu convite à arqueologia e genealogia das ciências humanas, percebemos o quanto as verdades construídas partem de um modelo de família que vigorava no regime vitoriano. Que as histéricas de Freud tenham ganhado destaque justamente nesse período não nos parece mera coincidência. A histeria parecia antes ser o produto de uma sociedade e de um modelo de família que exercia sobre o sujeito um poder sobre o uso do próprio corpo.

O campo onde essa repressão atuava não podia ser senão a família. É por essa via que a família surge tanto no discurso foucaultiano - como um paradigma, uma referência de conduta para com a sexualidade -, como no discurso psicanalítico - através das histéricas que manifestavam no corpo aquilo que era incompatível com o ideal vitoriano da família burguesa. No primeiro, a família se esgueira como um dispositivo que realiza determinações, a saber: é o espaço e o modelo imperioso do uso do corpo, da realização das legítimas práticas sexuais. A frase mais contundente do autor não deixa margem a interpretação, mas impõe-se como uma evidencia: “[...] o casal, legitimo e procriador, dita a lei”. (FOUCAULT, I985, p. Io)

No segundo, a família é quem adoece o sujeito, pois lhe impõe um modo de conduta que é incompatível com os desejos mais vivos no indivíduo. É o palco do sujeito dividido, culpado de um duplo desejo: matar o pai e possuir a mãe. Mas é, ao mesmo tempo, o lugar de surgimento das subjetividades. Mas se falamos em genealogia e arqueologia das ciências humanas, devemos antes considerar o que se constatava nesse período que figurava como o palco das elaborações freudianas. Quais acontecimentos são relevantes à nossa reflexão?

O principal, e extremamente irrelevante, segundo os autores que debatem a exaustão essa temática (HURSTEL, I999; ROUDINESCO, 2003; ZAFIROPULOS, 200I), o grande acontecimento do século não 
é outro senão o declínio do patriarcado. A família patriarcal que regia seu poder sem contestações perde espaço para o Estado. Essa mudança não acontece sem consequências para a família. $O$ pai fica descreditado socialmente. Essa, ao menos, é a hipótese que Lacan desenvolve em 1938 num

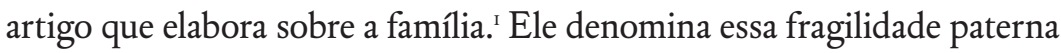
como resultante do "declínio social da imago paterna". Desse declínio surge o que se convenciona como "nascimento de uma nova figura paterna" (ROUDINESCO, 2003, p. 38). A autoridade paterna fica, portanto, submetida a uma outra autoridade, a do Estado. O pai, autoridade moralmente aceita, é antes de tudo submetido, ele também, a uma lei.

Lacan comenta o "declínio social da imago paterna" como uma consequência dos avanços culturais que incidem sobre a família: "Declínio condicionado pelo retorno sobre o indivíduo de efeitos extremos do progresso social, declínio que se manifesta, sobretudo nos nossos dias nas coletividades mais atingidas por esses efeitos: concentração econômica, catástrofes políticas"; mas também como o responsável por "um grande número de efeitos psicológicos", onde, a experiência psicanalítica "levanos a designar aí [na neurose] a determinação principal na personalidade do pai, sempre faltando de certo modo ausente, humilhada, dividida ou artificial” (LACAN, I987, p. 62). O mesmo autor continua

Seja qual for o futuro, este declínio constitui uma crise psicológica. Talvez seja a esta crise que se torna necessário relacionar a aparição da própria psicanálise. $\mathrm{O}$ sublime acaso do génio não explica talvez sozinho que isto aconteça em Viena - nessa altura centro de um Estado que era o melting pot das formas familiares mais diversas, das mais arcaicas às mais evoluídas, dos últimos agrupamentos agnáticos dos camponeses eslavos às formas mais reduzidas do lar pequeno-burguês e às formas mais decadentes da instabilidade da vida comum, passando pelos paternalismos feudais e mercantis - que um filho do patriarcado judeu tenha imaginado o complexo de Édipo. Seja como

${ }^{1}$ Este texto foi publicado, posteriormente, nos Outros Escritos sob o título Complexos familiares na formação do indivíduo. 
for, são as formas de nevroses dominantes no fim do século passado que revelaram ser intimamente dependentes das condições da família.

Mas porque o declínio do pai é tão relevante para Lacan? É na resposta a essa pergunta que encontramos a relação existente entre o declínio do pai e o surgimento da psicanálise. Por um lado, Lacan (1987, p. 62), acreditava que "um grande número de efeitos psicológicos" que correspondiam às neuroses contemporâneas, resultava da imagem desvalorizada do pai que surgia como consequência do que se convenciona como declínio do patriarcado. (ROUDINESCO, 2003) Por outro lado, Lacan observava que o complexo de Édipo surgia como resposta às novas neuroses, as ditas neuroses contemporâneas. Ele chega a afirmar que o complexo de Édipo freudiano "é o nó da maior parte das neuroses" (1987, p. 62) e "define mais particularmente as relações psíquicas na família humana...” (LACAN, I987, p. 45). O que Lacan propunha com essas afirmações? Lacan destacava nada menos do que a existência de uma relação entre o surgimento do complexo de Édipo e as novas formas familiares da modernidade, que por sua vez, se encontravam fundadas na nova figura paterna - a figura de um pai fragilizado socialmente.

Como bem observou Roudinesco (2003, p. 6o) quanto ao uso que Freud faz do Édipo, de Hamlet e dos deuses gregos, este:

[...] delineava com gênio sua grande cena do desejo do incesto e do assassinato do pai. Esta não tinha grande coisa a ver com a peça de Sófocles, nem com os deuses da Ática, nem com Shakespeare. Entretanto, inspira à civilização ocidental um modelo de romance familiar que prevalecerá durante um século.

O modelo de romance familiar ao qual a autora se refere não é outro senão a família edipiana, que equivalia à família burguesa. $\mathrm{O}$ complexo de Édipo seria então, segundo Roudinesco (2003) e também segundo Lacan (1987), a maneira que Freud encontrou de restituir ao pai um destaque na família. Assim, o complexo de Édipo, segundo a letra desses autores, pos- 
sibilitou à instituição familiar sobreviver a um colapso generalizado que a ameaçava destacando uma função simbólica que girava em torno da figura do pai. O pai em destaque no complexo de Édipo representa, de certa maneira, a sobrevivência da autoridade do pai que se encontrava ameaçada, sob uma outra forma de atuação - designada por Freud de complexo paterno e por Lacan de função paterna.

Todos os trabalhos recentes sobre a história das origens da psicanálise, [...], mostram que a psicanálise nasce da interrogação que atravessa a sociedade vienense do fim do século passado face ao declínio da família patriarcal [...]. Existia em Freud uma vontade de revalorizar simbolicamente o pai [...]. É ainda Jacques Lacan quem, sob a forma de uma função simbólica essencial à organização da família, reintroduz a imagem do pai $^{2}$ (ROUDINESCO apud ZAFIROPOULOS, 200I, p. I2)

Vamos direto à letra de Freud. Se recorrermos às cartas de Freud a Fliess, na Carta 64, publicada em I897, percebemos a manifestação do desejo de encontrar um pai causador da neurose, desejo interpretado a partir de um sonho seu. Num anexo a essa carta, o Rascunho N, Freud persiste nessa ideia, porém não mais como um desejo pessoal que aparece em sonho, mas sim como uma ideia de um pai e uma mãe participantes da neurose do filho, ideia essa que começa a ganhar corpo na sua obra. Ele continua: "Os impulsos hostis contra os pais (desejo de que eles morram) também são um elemento integrante das neuroses. [...] Parece que esse desejo de morte, no filho, está voltado contra o pai e, na filha, contra a mãe" (FREUD, 1996, p. 304). Essa parece ser a primeira vez que se manifestam indícios do complexo de Édipo que Freud desenvolverá meses depois. $\mathrm{Na}$ Carta 7I, também publicada em I897, mais ou menos cinco meses depois, Freud vai se aproximando cada vez mais do conceito de complexo de Édipo, mencionando pela primeira vez o nome de Édipo: "Verifiquei, também no meu caso, a paixão pela mãe e o ciúme do pai, e agora considero

2 Original em Francês. 
isso como um evento universal do início da infância...”. Continua: “Cada pessoa da platéia foi, um dia, em germe ou na fantasia, exatamente um Édipo como esse, e cada qual recua, horrorizada, diante da realização de sonho aqui transposta para a realidade...”. (FREUD, i996, p. 316)

É em I900, pouco tempo depois da Carta 7I, com $A$ Interpretação de sonbos que encontraremos publicada pela primeira vez a referência ao Édipo. Nesse momento sua preocupação central parece ser a relação pai e filho, desenvolvendo a partir daí todo um pensamento de reflexão a respeito do Édipo Rei de Sófocles: o filho que mata o pai e se casa com a mãe, sem o saber, e que sente culpa ao descobrir-se impuro, punindo-se com a cegueira.

Freud (2003, p. 65) propõe com o complexo de Édipo uma outra ordem familiar, a edipiana, que, segundo Roudinesco, "restabelece simbolicamente diferenças necessárias à manutenção de um modelo de família que se temia que estivesse desaparecendo na realidade”. Se essa foi a pretensão de Freud, não foi isso que o desenrolar dos acontecimentos históricos nos demonstraram, como atesta a própria Roudinesco. Antes de alcançar seu propósito de restaurar a antiga ordem familiar, a psicanálise "contribuiu para a eclosão, no seio da família afetiva, de novos modos de parentalidade [...] ao mesmo tempo se tornando o fermento de um duplo movimento social que vinculava a emancipação das mulheres e dos filhos [...] à rebelião dos filhos contra os pais”. (FREUD, 2003, p. 93)

Porém, como denuncia a sequência dos acontecimentos, esse duplo movimento social não podia ainda acontecer senão de modo silencioso, "autorizados em surdina” (FOUCAULT, I988, p. Io), o que nos faz retornar à Introdução de Foucault.

No regime vitoriano, essa rebelião só podia se manifestar num outro lugar - no íntimo de cada sujeito, e a histeria era o produto dessa repressão. É para onde nos guia a leitura de Roudinesco (20I4, p. 63, tradução nossa): 


\begin{abstract}
A histeria se tornou em toda a Europa a expressão de uma revolta impotente das mulheres contra o poder patriarcal preocupado com um espectro de uma possível feminização do corpo social. À Viena, essa revolta restava confinada no círculo das famílias burguesas. Mas em Paris - vila dos movimentos revolucionários - ela adquiria um sentido mais político que a Medicina do Estado se pretendia ao ser popular e republicana.
\end{abstract}

Dessa forma, a nova ordem econômica se enraíza poderosamente na intimidade mais recôndita do sujeito humano. $\mathrm{O}$ que a burguesia inaugura vai muito além de uma nova ordem social, econômica e cultural. Ela instaura uma nova maneira de compreender o homem e sua subjetividade. E nessa perspectiva é Roudinesco (20I4) que nos direciona à compreensão da psicanálise - a partir dos estudos sobre a histeria - como um movimento político, econômico e cultural, no sentido mesmo de resguardar a sociedade moderna das ameaças que as mudanças decorrentes das revoluções fins de século XVIII acabaram por influenciar:

O paradigma da 'mulher histérica' [...] dá lugar a um estado de sociedade onde as mulheres não tinham outro meio, de exprimir sua aspiração à liberdade, a não ser pela exibição de um corpo em sofrimento. [...] As burguesas ganham o direito à uma vida privada, a um sentimento íntimo. Seu sofrimento existencial permite aos homens da ciência elaborar uma nova teoria da subjetividade. (ROUDINES$\mathrm{CO}, 2014$, p. 87)

O que Foucault irá demonstrar, no curso do seu texto, é que o triunfo do discurso das ciências humanas, e aqui mais estritamente o discurso da psicanálise, vincula-se estreitamente às formas de poder na tecelagem das condutas. É essa ordenação, categorização das condutas que acaba por se constituir uma nova forma de organização psíquica própria das sociedades modernas. Submetida não mais à autoridade do patriarca, mas aos novos modos de parentalidade que funcionam a partir de seus efeitos simbólicos. 
As histéricas são, portanto, produtos de uma sociedade que quer escamotear as verdades das famílias burguesas. Freud é ele mesmo efeito dessas variações que sua época promove nas famílias, assim como sua obra também o é. Nesse adentro da psicanálise como discurso de um saber, usando a lupa de Foucault, numa historicização das ciências do homem, percebemos o quanto a obra freudiana equivale ao testemunho dos desencontros e desacertos da família burguesa. O salto, no entanto, vale destacar, é perceber-se não como um Édipo, culpado e cego, ou um Hamlet, culpado e neurótico, mas sim compreender que, na realidade, algo de si mesmo sempre escapa ao homem.

[...] Freud tinha a conviç̧ão que sua doutrina devia ser antes uma ciência
do psiquismo, susceptível de subverter o campo da psicologia, e onde
os fundamentos se inscreveriam na biologia e nas ciências naturais. Em
realidade, ele traz com sua obra é bem outra coisa: Uma revolução do
íntimo, resultado do Iluminismo sombrio e do Romantismo Noir, uma
revolução ao mesmo tempo racional e assombrada pela conquista de
rios subterrâneos [...] tal era a promessa da viagem freudiana ao coração
de um inconsciente definido como 'outra cena', e que supunha uma or-
ganização das estruturas da parentalidade suscetível de perceber as mo-
dalidades de uma nova ordem familiar do qual ele desejava ser o clínico,
mas também era o ator. (ROUDINESCO, 20I4, p. Io4)

Até aqui, o que obtivemos? Primeiro, um deslocamento de olhar: não nos deve interessar exclusivamente o conteúdo quando estudamos o sujeito humano, especialmente a família, como estrutura aglutinadora. Foucault se diverte com as ilusões metodológicas que se propõem extrema objetividade sem uma olhadela crítica para o modo mediante o qual o discurso é composto. Portanto, o primeiro ganho é de ordem metodológica. Quer dizer, o esforço do autor não se encaminhará para um exercício do tipo epistemológico, demonstrando a logicidade conceitual dos discursos constitutivos das ciências humanas. Sua preocupação, ao contrário, é rastrear as condições pelas quais tal ou qual discurso foi construído. Assim tentamos fazer com a contribuição da obra de Roudinesco. 
Em segundo lugar, a certeza de que pouco sabemos. Isso, o velho e bom Descartes já nos ensinou há quase quatro séculos com a sua moral provisória. Cabe aos cientistas que enunciam verdades terem em mente que a parte significativa dos seus discursos é tão somente da ordem da doxa, porque a realidade, e aqui a realidade familiar, é muito mais complexa. Pouco sabemos, portanto, sobre a família e sobre a sexualidade, pois que as construções sobre esses conceitos são mediados pelos discursos dos saberes. Pouco sabemos igualmente sobre nós mesmo, sobre nossos desejos, a liberdade subjetiva só é possível ao preço da aceitação de um determinismo inconsciente. (ROUDINESCO, 20I4) É impossível, portanto alcançarmos toda verdade do sujeito, algo resta sempre inconsciente.

Para concluir, todo o encaminhamento que Foucault oferece à sua investigação delineada nessa Introdução de sua obra última revela que o resultado ao qual seguramente chegamos confirma que o uso da categoria família não é feito como e enquanto categoria epistêmica. Trata-se bem mais de refletir acerca dos discursos que erigem categorias, sopesando os resultados invisíveis deles. Neste caso particular, bem mais que identificar a força coercitiva da família na constituição do sujeito, o que seguramente Foucault ressalta é que ela seja um locus que encerra também uma força promotora de condutas. Como lugar de poder, não pode ser concebido como exclusivamente restritivo, repressor. Para além disso, ali o sujeito torna-se o que é, inscrevendo nela seus próprios movimentos modeladores. Como o sexo, a família é uma força incitadora de subjetivação. Em que consiste isso? Certamente temos aqui um outro tema para desdobramentos futuros. 


\section{Referências}

FONSECA, M. Michel Foucault e a constituição do sujeito. São Paulo: Educ, 1995.

FOUCAULT, M. História da sexualidade: a vontade de saber. São Paulo: Graal, I985. v. I.

FREUD. Carta 52 (I896). In: FREUD. Extratos dos documentos dirigidos a Fliess (1950 [1892-1899]). Rio de Janeiro: Imago, 1996. p. 28I-288. (Edição standard brasileira das obras psicológicas completas de Sigmund Freud, v. I).

FREUD. Carta 64 (I897a). In: FREUD. Extratos dos documentos dirigidos a Fliess (1950 [1892-1899]). Rio de Janeiro: Imago, 1996. p. 303-304. (Edição standard brasileira das obras psicológicas completas de Sigmund Freud, v. I).

FREUD. Carta 7I (1897b). In: FREUD. Extratos dos documentos dirigidos a Fliess (1950 [1892-1899]). Rio de Janeiro: Imago, 1996. p. 314-317. (Edição standard brasileira das obras psicológicas completas de Sigmund Freud, v. I).

FREUD. A interpretação dos sonbos (I900). Rio de Janeiro: Imago, 1996. (Edição standard brasileira das obras psicológicas completas de Sigmund Freud, v. I).

GIARD, L. Michel Foucault, lire l'oeuvre. Paris: J. Millon, 1992.

HAN, B. L 'Ontologie Manquée de Michel Foucault Paris: J. Millon Collection Krisis, 1998.

HURSTELS, F. As novas fronteiras da paternidade. São Paulo: Papirus, I999. p. 23I.

JALÓN, M. El Laboratório de Foucault, Decifrary Ordenar Buenos Aires: Antrophos, 1994 .

LACAN, J. A familia. Lisboa: Assírio \& Alvim, 1987.

ROUDINESCO, E. A familia em desordem. Rio de Janeiro: Jorge Zahar, 2003. ROUDINESCO, E. Sigmund Freud en son temps et dans le nôtre. Paris: Éditions du Seuil, 2014.

TRONCA, I. Foucault Vivo. Campinas: Pontes, 1987.

VERÓN, E. Analisis de Michel Foucault. Buenos Aires: Tiempo Conteporáneo, I996. 
VEYNE, P. Como se escreve a bistória. Foucault revoluciona a história. Brasilia: $\mathrm{UNB}, 1982$.

ZAFIROPOULOS, M. Lacan et les sciences sociales. Le déclin du père (1938I953). Paris: PUF, 200I. p. 258.

80

क्के 


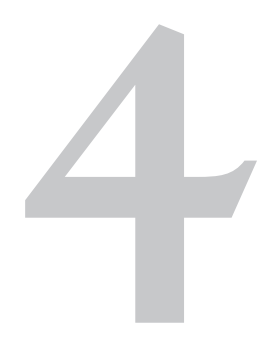

\title{
Falas de que família(s)? Era uma vez papai, mamãe e filho(s)...
}

\author{
औัติ \\ Enézio de Deus Silva fúnior
}

As falas aparentemente majoritárias sobre família, na contemporaneidade, ainda a demarcam no singular, como se a sua complexidade relacional já não houvesse implodido os discursos que a naturalizam de formas nuclear heteronormativa, rigidamente binária quanto ao gênero e hierarquizada tendo o homem como chefe supremo. O Seminário Enlaçando Sexualidades, ${ }^{1}$ em sua quarta edição, ajudou-nos no repensar,

${ }^{1}$ O evento mantém o perfil científico-extensionista de vanguarda, dando conta das múltiplas realidades que, tocando as vidas dos sujeitos na plural/complexa sociedade contemporânea, tornam-se objetos de contínuas reflexões interdisciplinares. A mesa "Novos e velhos 
com mais profundidade, sobre o que refletiremos neste curto espaço dialógico-textual a respeito das famílias no hoje plural/diverso e mutante.

Dando conta de olhares interdisciplinares sobre relações familiares, Castro (20I4), em trabalho recente, propõe um diálogo entre Winnicott, 82 feministas e sociólogos sobre as interfaces gênero e família; diálogo por meio do qual assegura que "a historia das famílias, no Brasil, não é homogênea" e que, "hoje, no Brasil, por distintos processos históricos, a família viria se diversificando”. (CASTRO, 20I4, p. 2I) Entretanto, a constatação desta diversificada mutabilidade no campo familiar - com os novos e necessários olhares/investigações confirmando a complexidade de tal objeto; desde sempre em transformação, teórica e faticamente, a família - ainda "convive" com a velha repetição de discursos/representações que, quais fábulas, insistem na redução heterosexista nuclear: "era uma vez papai, mamãe e filho(s)".

Em outras palavras, mesmo ante as incontestáveis diversidades de relações, direitos, deveres, vínculos (laços de convivência íntima, aproximações por manifestações de desejo e outras características/manifestações relevantes na contemporaneidade para que nos demos conta das famílias com maior precisão), persistem as repetições de narrativas, padrões, preconceitos, discriminações, violações/violências heteronormativas (SILVA JÚNIOR, 20II, p. 495) que não admitem outros modelos de existência afetivo-sexual fora do nuclear heterossexual e com filhos preponderantemente biológicos (Idem, 2005, p. 127).

Neste sentido, por exemplo, recebemos, perplexos, um parecer do ano de 20 II (três meses antes da vanguardista/histórica decisão do Supremo Tribunal Federal sobre as uniões homoafetivas no Brasil), cuja fundamen-

arranjos familiares", nesta esteira, revelou convergência de esforços dialógicos/inquietações científicas entre as pesquisadoras Márcia Macedo da Universidade Federal da Bahia (UFBA), Ana Uziel da Universidade Estadual do Rio de Janeiro (UERJ) e Fátima Lima da Universidade Federal do Rio de Janeiro (UFRJ), sob a nossa mediação, cujas falas enlaçaram cientificamente: a chefia de famílias por mulheres baianas, a homoparentalidade e o poliamor. 
tação jurídica reflete - em pleno século XXI e num novo milênio - aquele estagnado modo de ver a família conforme idealizada, quase de forma "sagrada”, pelo legislador do Código Civil brasileiro de ı9ı6. Barbosa (20II), parecerista e atualmente docente do Programa em Família na Sociedade Contemporânea da UCSAL, assim se posiciona, respondendo ao consulente João Carlos Petrini:

Dentro da ótica biológica/reprodutiva, casamento é a união de pessoas de sexos diferentes vinculadas entre si pela prática de atos reprodutivos. [...] Juridicamente, [...] é a situação social de duas ou mais pessoas a quem o Estado atribui a qualidade de casados, reconhecendo e outorgando prerrogativas e obrigações próprias enquanto casal em suas relações externas, bem como prerrogativas e obrigações próprias de cada um de seus membros em suas relações internas. [...] Dificuldade ocorre no direito brasileiro, o qual não elencou, entre as causas de nulidade, por exemplo, o casamento contraído por pessoas de mesmo sexo. Uma interpretação levada a efeito sem os cuidados devidos levaria à conclusão de que o que não é proibido, é permitido. Ora, tal entendimento contraria frontalmente todas as regras de hermenêutica, mormente aquelas de ordem lógico-sistemática, posto que todo o sistema matrimonial brasileiro se estrutura na ideia do casamento heterossexual e monogâmico. [...] O sistema normativo brasileiro, consideradas as normas constitucionais, infraconstitucionais, princípios, usos e costumes, não contempla a possibilidade de casamento entre pessoas de mesmo sexo. [...] Parece-me ser parcialmente compativel a união estável entre pessoas de mesmo sexo com as normas constantes na Constituição Federal de I988, no Código Civil e em legislações esparsas, tais como o Estatuto da Criança e do Adolescente. [...] A única possibilidade de reconhecimento de casamento entre pessoas de mesmo sexo no Direito Brasileiro é a mudança da Constituição Federal, o que implicaria a adequação das normas infraconstitucionais. (BARBOSA, 20II, p. 9, I4, I5, I8, $20,22,26$, grifos nossos) 
Em oposto polo de fundamentação, menos de três meses depois, a mais alta corte jurídica do país atingiu, por unanimidade dos io ministros votantes na longa sessão dos dias 4 e 5 de maio de 2orI, consenso completamente diverso, mencionando, no bojo dos votos, pesquisadores como Fachin - que, do seu lugar de jurista, admite que "a família, como realidade sociológica, apresenta íntima ligação com as transformações operadas nos fenômenos sociais" (1999, p. II). No mesmo sentido, destacam-se outros pesquisadores do direito, como Farias e Rosenvald (2012, p. 39), para os quais somente é possível investigar e se posicionar sobre as famílias na sociedade contemporânea "à luz da interdisciplinaridade; máxime na sociedade contemporânea, marcada por relações complexas, plurais, abertas, multifacetárias e (por que não?) globalizadas”.

Exatamente assim empreenderam, por viés interpretativo inclusivo, os referidos dez ministros do STF, a partir de cuja decisão, pelo expresso reconhecimento do caráter familiar das relações afetivas entre pessoas do mesmo sexo no Brasil, atribuíram-lhes, via analogia, através de interpretação conforme à Constituição, o status constitucional de uniões estáveis, abrindo caminho para que, meses depois, tornasse-se possível, sem possibilidade de negativa por parte dos cartórios brasileiros, a celebração do casamento entre tais pessoas no Brasil (vide obra que coordenamos sobre tal emblemática decisão: SILVA JÚNIOR, 20I2). Afinal, crenças particulares e sistemas religiosos à parte, no Estado Laico e Democrático de Direito, como é o nosso, o aspecto civil ou contratual - direitos, deveres, impedimentos, etc. - do casamento (bem diverso da noção de matrimônio) é o que, unicamente, deve ser levado em conta pelos agentes e administradores públicos dos três poderes da República, bem assim pelos(as) pesquisadores(as) cientificamente atentos(as) às transformações sintonizadas com a necessidade de haver o pleno respeito à dignidade de todas as pessoas, sem qualquer exceção.

No campo das investigações sobre as famílias na contemporaneidade, portanto, mais acertadas do que as tentativas afirmando-se científicas como também se verificou com a homossexualidade (SILVA JÚNIOR, 
20II, p. I27-I29) - mas funcionalmente restritivas, epistemologicamente excludentes e/ou conceitualmente linearizantes (como se o fenômeno familiar "evoluísse" ou se transformasse em um só sentido pré-estabelecido/ geral) são as crescentes aproximações teóricas sobre aspectos que tocam as realidades familiares de formas sistêmica e interdisciplinar (maternidade, paternidade, gerações, sexos, etc.), dando conta das mudanças contínuas, a partir de escolhas metodológicas capazes de ofertar maior segurança científica aos(às) pesquisadores(as).

Therborn (2006, p. 429), por exemplo, em sua clássica obra sobre a família no século XX, a partir do que identifica como três conjuntos de processos familiares - a trajetória dos direitos e poderes dos pais e maridos, ou seja, do patriarcado; as vicissitudes do casamento e da parceria sexual extramarital e a trajetória transformada de fecundidade humana -, rejeita a ideia de "evolução" ou "linearidade", que jamais existiu na seara familiar dos pontos de vista historiográfico, sociológico, antropológico ou em qualquer outro cientificamente válido. Referenciando o seu esforço de pesquisa, ao avaliar, quanto ao intervalo dos anos I900 a 2000, "a dinâmica global das mudanças da família no período e com uma breve avaliação da soma das mudanças” (Idem), o sociólogo sueco conclui que, "no decorrer do século passado, a instituição da família mudou em todo o mundo.” (THERBORN, 2006, p. 429)

O Brasil contemporâneo tem revelado importantes papeis/ativismos de juristas e entidades de matriz jurídica, como o Instituto Brasileiro de Direito das Famílias (IBDFAM), quais vetores de fortalecimento das mudanças/quebras de preconceitos na seara familiar, ora a partir dos fundamentos de incontáveis decisões arrojadas/inovadoras dos Tribunais Superiores do país - especificamente nas últimas duas décadas (SILVA JÚNIOR, 20I2) -, ora por esforços de pesquisa no sentido de considerar a família um "locus privilegiado para garantir a dignidade humana e permitir a realização plena do ser humano” (FARIAS, 20IO, p. I), liberto de aprisionamentos heteronormativos, machistas, racistas e de outras ordens sobrepostas. (MESSEDER, 20I4) 
Nesta direção, o que, na tríade francesa Liberté, Egalité, Fraternité do século VXIII, constituía o terceiro elemento (a fraternidade) passou a ser teorizado, no plural Direito das Famílias, como o princípio da solidariedade aplicado às relações familiares (LÔBO, 2007), imbricado com outros não menos importantes (que se tornaram balizadores de novas fundamentações jurisprudenciais e doutrinárias), como o da afetividade e o do livre desenvolvimento da personalidade. A solidariedade - que, ao lado da liberdade e da igualdade, passou a constituir, literalmente, um dos objetivos fundamentais da nossa República Federativa (art. $3^{\underline{o}}$, I, CF/88) -, foi expandida, da teoria dos Direitos Humanos, como parte crucial da sua terceira geração ou dimensão, para as análises das relações e direitos familiares.

Daí nasceu, a partir de civilistas como Lôbo (2007, p. 4), a concepção eudemonista das famílias, correlacionada à matriz epistemológico-grega, na medida em que, no campo dos seus vínculos e desdobramentos, o mais relevante sentido familiar tem sido, de fato, a harmonia de "consentimentos concretos sem assimetrias, desejos sem clausuras...” (MESSEDER, 20I4), isto é: a legítima busca/preservação da felicidade, por meio de uma liberdade individual funcionalizada à realização da solidariedade promotora do bem de todos(as) os demais membros(as), sem distinção de qualquer natureza. "A família brasileira, na atualidade, está funcionalizada como espaço de realização existencial das pessoas em suas dignidades e como locus por excelência de afetividade." (LÔBO, 2007, p. I, 3, 9) Tal foi muito bem refletido na Constituição Federal de I988 - jurídica e socialmente, a mais inovadora/ comprometida com relação às famílias -, cujos contornos epistemológicos, conceituais e direitos (objeto da nossa tese de doutorado, sob a ótica da Análise de Discurso Francesa) sofreram alargamentos e modificações tais, que alguns familiaristas, sem exagero, afirmam que, na seara familiar, a nova ordem constitucional promoveu uma espécie de "revolução" (SÁ, 2004, p. 436), modificando paradigmas do direito de família e o constitucionalizando de tal modo, que este ramo do direito civil não mais se sustentou (para ser visto ou interpretado) sem o respaldo de artigos como o art. 226 da Lei Maior/88. (REIS, 2008, p. 225). 
Nesse processo polissêmico/de rupturas, mudanças, desde quando surgiram os primeiros livros jurídico-científicos no Brasil aproximando o (então singularizado) Direito de Família das uniões entre pessoas do mesmo sexo - como a nossa defesa da adoção de crianças e adolescentes por casais homossexuais (SILVA JÚNIOR, 20II) -, efervesciam os debates e esforços de outros autores sobre o espaço que as novas configurações e direitos familiares, merecidamente, passariam, como reflexo natural das mudanças sociais contundentes, a conquistar; não somente onde já estavam pululando (em livros paradidáticos, artigos, pesquisas de graduação, de pós-graduação lato e stricto sensu), mas nas decisões de juízes de primeiro grau, de tribunais superiores e na própria lei escrita.

Do ponto de vista jurídico-científico, portanto, considerável literatura qualificada, especialmente afeta ao direito das famílias, vem lastreando mais produções acadêmicas e reforçando a direção que, a partir dos anos 2000 no Brasil em especial, começamos a reivindicar (SILVA JÚNIOR, 200I, p. II3-I2O): o respeito às diversas possíveis configurações/arranjos familiares justificados(as) pelo afeto e aos direitos decorrentes de suas relações, com fundamento nos já mencionados princípios constitucionais de hodierna recorrência nos julgados dos Tribunais Superiores. Por tudo isto, ainda que convivamos com tantos fundamentalismos atávicos, face aos contemporâneos arcabouços teóricos afetos ao pluralizado direito das famílias e em sintonia as veredas abertas pelo texto da Constituição Federal de I988 nos âmbitos dos direitos e relações familiares, não faltam - à doutrina (juristas, pesquisadores da área jurídica), à jurisprudência (Tribunais, magistrados) e aos legisladores infraconstitucionais - subsídios para a potencialização das conquistas já asseguradas, assim como a contínua atualização dos sentidos constitutivo-transformadores presentes nos artigos constitucionais sobre a matéria: 226 (em especial), 227, 228, 229 e 230. Seus fortes traços polissêmicos, portanto, se cotejados com as pretéritas previsões constitucionais pátrias sobre a família no Brasil, atestam, na $\mathrm{CF} / 88$, aquilo que o eco luso-jurista (CANOTILHO, I989, p. 3) sintetizou referindo-se ao seu peculiar contexto: "novos paradigmas, novos saberes, novos direitos". 
Ante as ingerências de religiosos fundamentalistas onde não deveriam (como nas esferas públicas do nosso laico Estado: Assembleias/Câmaras Legislativas e Senado Federal, por exemplo), salutar a persistência/resistência de pesquisadores/as como nós, reunidos(as) neste IV Seminário Enlaçando Sexualidades, ombreados nas trincheiras de esclarecimento científico, debates e lutas por uma sociedade, de fato, mais livre, justa e solidária quanto às diversas possibilidades de a vida ser experienciada/ compartilhada afetiva e/ou intimamente. Entre, pois, os novos e velhos arranjos familiares, preferimos a incômoda posição da transformação - da polissemia, do novo, da ruptura, mudança, movência (ORLANDI, 2003, p. 36-39) - à das "fábulas" que, estagnadas numa contemporaneidade tão plural/mutante, insistem na naturalizada família nuclear homem-mulherfilho(s), idealizada pelo legislador do Código Civil de ı9ı6. Em tais narrativas, não há voz para o que - desde sempre - vilipendiado pelos sistemas/ lógicas excludentes, como o complexo ideológico heteronormativo rigidamente binário de gênero.

Por tudo isto, aqui estamos/permanecemos lanças em trânsito, enlaçando: embora envergadas quais caniços por segundos (quando inevitável, somente para demarcarmos/conquistarmos novos espaços em prol de mudanças que emancipem, libertem), adiante logo erguidas intransigentes/fortes na mesma fluidez do tempo, dos múltiplos espaços e da vida como um todo - para que o mundo respeite as diversidades existenciais.

\section{Referências}

BARBOSA, C. de L. C. Parecer sobre o casamento entre pessoas do mesmo sexo no Brasil. Consulente: João Carlos Petrini. 20II. Disponível em: <http://www. faculdadebaianadedireito.com.br/images/a/Parecer\%20-\%20Casamento\%20 entre\%2opessoas\%2ode\%2omesmo\%2osexo.pdf>. Acesso em: 20 nov. 2015. 
CANOTILHO, J. J. G. Direito constitucional. Coimbra: Almedina, 1989.

CASTRO, M. G. É possível um diálogo entre a Psicanálise Winnicottiana e o Feminismo de corte Sociológico, quando o foco é gênero e família? Notas a partir de leituras cruzadas sobre maternidade - Nancy Chodorow e D. W. Winnicott. Revista Diálogos Possiveis, Revista da Faculdade Social da Babia, Salvador, Ano I3, n. 2, p. 26, jul./dez. 20I4. Disponível em: <http://revistas. faculdadesocial.edu.br/index.php/dialogospossiveis/article/view/229/182>. Acesso em: Io jul. 2015.

FACHIN, L. E. Elementos críticos de direito de familia. Rio de Janeiro: Renovar, I999.

FARIAS, C. C. de. Direito à Familia. Revista furídica da UNIFACS, Salvador, 20Io. Disponível em: <http://webcache.googleusercontent.com/ search?q=cache: $04 \mathrm{fj} 4 \mathrm{p} Y \mathrm{xU}-\mathrm{YJ}$ :www.unifacs.br/revistajuridica/arquivo/edicao_ marc02004/docente $/$ doco $4 \cdot d o c+\& c d=2 \& h l=p t-B R \& c t=c l n k \& g l=b r>$. Acesso em: IO ago. 2015.

FARIAS, C. C. de; ROSENVALD, N. Curso de Direito Civil: famílias. 4. ed. Salvador: Jus Podivm, 20I2. v. 6.

LÔBO, P. L. N. Princípio da solidariedade familiar. FusNavigandi. 2007. Disponível em: <http://jus.com.br/artigos/25364/principio-da-solidariedadefamiliar>. Acesso em: 17 jun. de 2015.

MESSEDER, S. A. Apresentação. In: SEMINÁRIO ENLAÇANDO SEXUALIDADES. 3. 20I4, Salvador. Disponível em: <http://www.uneb.br/ enlacandosexualidades $3 /$ sobre/>. Acesso em: I2 nov. 2015.

ORLANDI, E. P. Análise de discurso: princípios e procedimentos. 5. ed. Campinas-SP: Pontes, 2003.

REIS, M. R. A Constituição de I988 e o direito de família. In: ARAÚJO, J. C. de. Ensaios sobre impactos da Constituição Federal de 1988 na Sociedade Brasileira. Brasília, DF: Câmara dos Deputados, Edições Câmara, 2008. v. I. (Série Coleções Especiais / Obras Comemorativas n. 2). Disponível em: $<$ http://bd.camara.gov.br/bd/bitstream/handle/bdcamara/2915/ensaios_ impactos_volumer.pdf?sequence $=\mathrm{I}>$. Acesso em: 20 out. 2015.

SILVA JÚNIOR, E. de D. A possibilidade jurídica de adoção por casais homossexuais. 5. ed. Curitiba: Juruá, 20 II. 
SILVA JÚNIOR, E. de D. (Coord.) União estável entre homossexuais: comentários à decisão do STF face à $\mathrm{ADI}$ 4277/09 e à $\mathrm{ADPF}$ I32/08. Curitiba: Juruá, 2012. SILVA JÚNIOR, E. de D. Homossexualidade: caracterização, panorama bistórico, evolução terminológica e direito fundamental. In: VIEIRA, T. R. (Org.). Minorias sexuais: direitos e preconceitos. Brasília: Consulex, $20 \mathrm{I2}$. SILVA JÚNIOR, E. de D. Homofobia e violência doméstica. In: DIAS, M. B. (Coord.). Diversidade sexual e direito bomoafetivo. São Paulo: Revista dos Tribunais, 20II.

SILVA JÚNIOR, E. de D. Adoção por casais homossexuais. Revista Brasileira de Direito de Familia, São Paulo, Ano VII, n. 30, jun/jul. 2005.

SILVA JÚNIOR, E. de D. União homossexual: do preconceito ao reconhecimento jurídico. Revista Furídica Diké. Departamento de Ciências Furídicas, Ilhéus, , Ano III, n. 3, 200 I.

SÁ, M. de F. F. de. Monoparentalidade e biodireito. In: PEREIRA, R. da C. (Coord.). Afeto, ética, familia e o novo código civil. Belo Horizonte: Del Rey, 2004.

THEBORN, G. Sexo e poder: a família no mundo - 1900-2000. Trad.: Elisabete Dória Bilac. São Paulo: Contexto, 2006. 


\title{
O Programa Bolsa Família a partir das crianças beneficiadas:
}

\author{
uma abordagem das moralidades \\ engendradas pela \\ condicionalidade escolar ${ }^{\mathrm{I}}$
}

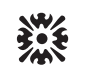

Flávia F. Pires

\section{Introdução}

Se a antropologia pauta-se desde Malinowski em captar o ponto de vista nativo, ${ }^{2}$ a ideia aqui é entender o Programa

${ }^{1}$ Agradecimentos devem ser prestados aos Catingueirenses, crianças e adultos, que generosamente participaram da pesquisa; à equipe de pesquisa que enfrentou os desafios do campo com valentia e, ao CNPq/MDS, por tornar possível esse revigorante exercício de pesquisa.

2 Embora a ideia de captar o ponto de vista nativo seja controversa para Favret-Saada (2005), Geertz (2002) afirma sua validade. 
Bolsa Família (PBF), seus efeitos na vida dos cidadãos, a partir do ponto de vista das crianças, esses sujeitos que constantemente são silenciados nas pesquisas, a despeito da sua crescente importância na vida social das famílias na contemporaneidade, como salienta Manuel Sarmento (2008). Fazemos com as crianças o que Suarez et al (2006) e Rego (2008) fazem com as mulheres: "a partir de[las]" - para usar uma expressão do professor Otávio Velho (NOGUEIRA; PIRES 20Io; PIRES; NOGUEIRA 20II) -, tentamos compreender o funcionamento e os efeitos do PBF. Isso quer dizer que "as vozes das crianças não devem ficar confinadas aos assuntos infantis", como afirma Allison James (2007, p. 267). Nesse sentido, situamo-nos entre os estudos que recentemente no Brasil vem tomando as crianças como sujeitos e interlocutores da pesquisa sem, no entanto, excluir os adultos, a partir de uma inspiração nos trabalhos de Christina Toren (1999).

O PBF é um programa de transferência mensal de renda condicionada que surgiu em 2003 e foi sancionado em 2004, a partir da unificação de uma série de programas sociais. O PBF é responsável, junto com outros programas de transferência de renda, por 21\% na queda na desigualdade no Brasil (1995-2004). Junto com o Benefício de Prestação Continuada foi responsável por $28 \%$ da redução do Índice Gini ${ }^{4}$ no mesmo período. O custo do Programa é de cerca de $0,4 \%$ do Produto Interno Bruto (PIB) nacional (R \$I,4 bilhão em março 20II), ou seja, considerado baixo, tendo em vista seus impactos macroeconômicos e sociais (SOARES et al., 2006). Como afirmam Medeiros et al (2007, p. 2I): "O lado positivo dos programas analisados é indiscutível. Seus impactos sobre pobreza e desigualdade são visíveis”. (PIRES 20I3, 20I4; MEDEIROS et al 2007; LAVINAS; BARBOSA, 2000).

Embora houvesse por parte da academia, no início de sua implantação, uma reação à exigência de condicionalidades que parecem ferir os direitos

\footnotetext{
3 "the voices of children should not be confined to childish concerns".

${ }^{4}$ O Índice ou Coeficiente Gini serve para medir a desigualdade social.
} 
humanos (ZIMMERMAM, 2006; SILVA 2007; DINIZ 2007); frente aos resultados positivos parece-nos que hoje o debate em torno do PBF volta-se para o seu aperfeiçoamento e as estratégias para lidar com o objetivo último do Programa: a quebra do círculo intergeracional da pobreza e criação de uma cultura cidadã, que parecem ainda estar distante de serem alcançadas. Por isso, vemos crescer os estudos sobre: avaliação; o empoderamento feminino e a consequente reestruturação do poder e status dos membros familiares (REGO, 2008; SUÁREZ et al., 2006; PIRES, 20I4); a escola e os entraves para uma escolarização de qualidade (MONNERAT et al. 2007); a precária rede de assistência à saúde (SILVA, 2007); o trabalho infantil (PIRES; JARDIM, 20I4), dentre outros.

\section{Objetivos}

Este artigo tem como objetivo apresentar alguns resultados de pesquisas de campo realizadas entre 2009 a 201 n na Universidade Federal da Paraíba (UFPB), sob coordenação da professora Flávia Ferreira Pires, com a equipe de pesquisadores composta por Patrícia Oliveira Santana dos Santos, Fernando Antonio Dornelas Belmont Neri, Edilma Nascimento Sousa, Christina Glayds Nogueira Mingarelli, Daniela Oliveira Silveira, Christiane Rocha Falcão, Jéssica Karoline Rodrigues, Tatiana Benjamin, Antônio da Silva e George Ardilles da Silva Jardim. Aqui nos deteremos a realizar uma avaliação do $\mathrm{PBF}$, levando em conta a opinião e a voz das crianças catingueirenses beneficiadas.

As pesquisas têm proporcionado vários debates que não poderão ser aqui analisados. Patrícia Oliveira Santos (20I4) no Programa de Pós-Graduação em Antropologia (UFPB), no curso do mestrado, dedicou-se a compreender as consequências das condicionalidades, cuja punição apenas incide sobre as famílias com crianças em idade escolar, tema o qual também foi debatido na sua monografia de fim de curso (Santos, 20II). Jéssica Silva (20II) dedicou sua monografia de fim de curso a entender a profundidade das mudanças sociais como resultado da expansão do 
consumo, principalmente infantil, propiciado pelo benefício. Edilma do Nascimento Souza (20II) e George Ardilles Silva Jardim (20IOa) nas suas monografias de fim de curso dedicaram-se à dinâmica familiar geracional no que diz respeito a escolarização das crianças mais jovens, em detrimento das gerações anteriores. George continua pensando como o PBF atravessa o tema do trabalho infantil através de um recorte geracional. Com ele escrevemos um artigo que sugere a ideia de uma "geração Bolsa Família”. (PIRES; JARDIM, 20I4) Além desses, Antonio Silva (20II), Silva e Pires (20II), Benjamin 20I0, Pires e colaboradores (20II), Silva Jardim (2OIOb) são apenas alguns estudos realizados pelo nosso grupo de pesquisa Criança: Sociedade e Cultura (CRIAS) e dialogam intensamente com a pesquisa aqui apresentada.

Nesse sentido, o texto aqui apresentado tem como objetivo central realizar uma avaliação do PBF na cidade de Catingueira, Paraíba, a partir das crianças. Para isso, lançaremos mão de alguns dados empíricos considerados relevantes pelos próprios nativos quando o assunto é o Programa. Dedicaremos atenção ao papel da condicionalidade escolar na manutenção do benefício e discutiremos as consequências da imposição da frequência escolar para a população estudada de um ponto de vista moral.

\section{Metodologia}

Usamos como técnica de pesquisa a observação participante, na medida em que cada pesquisador ficou "hospedado" na casa de uma família beneficiada, ali realizando suas refeições, as pernoites e vivenciando o cotidiano familiar. Além disso, a equipe realizou "Oficinas de Pesquisa" que funcionaram por dois dias, em dois turnos e aconteceram em uma das escolas da cidade, em duas salas de aula adequadamente preparadas, durante as férias escolares. As Oficinas de Pesquisa consistiram em seis grupos focais de aproximadamente i hora e 30 minutos, com crianças de 6 a 8 anos (dois grupos), 9 a Io anos (dois grupos), e II a I2 anos (dois grupos), e desenhos e redações temáticas. Foi solicitado às crianças que desenhassem ou escrevessem sobre o PBF e uma vez terminada a atividade, 
as crianças apresentaram suas obras para os colegas e os pesquisadores. (PIRES, 200Ira, p. 31-62) As atividades nas “Oficinas de Pesquisa” eram estruturadas da seguinte forma: boas vindas; solicitação do consentimento das crianças em participar da pesquisa, pedido de autorização para uso dos desenhos, redações e depoimentos; apresentação de cada participante através de uma brincadeira; rodada de perguntas (grupo focal propriamente dito); pausa para lanche; produção de desenhos e redações; socialização dos desenhos e redações; e finalmente a despedida com uma brincadeira. As perguntas versavam sobre o entendimento e avaliação do $\mathrm{PBF}$, acesso ou não a bens de consumo e serviços infantis e familiares, empoderamento feminino e infantil, percepções de classe social, trabalho e escola.

Vários acontecimentos sensibilizariam a equipe, como quando Júlio César, de 7 anos de idade, que ao invés de devorar o seu sanduíche, como as outras crianças faziam, preferiu guardá-lo para levar para sua avó. As precárias condições de vida das famílias "hospedeiras", que em alguns casos não dispunham de água encanada e saneamento básico, levando a pesquisadora a apreciar a água que sai da torneira na pia da sua cozinha não mais como regra, mas como uma excepcionalidade. $\mathrm{O}$ envolvimento afetivo criado entre pesquisadores e as crianças das casas onde moraram, especialmente em uma casa chefiada pelo pai, cuja mãe estava ausente. As negociações entre pesquisadores e nativos foram constantes e objeto de intensas discussões no grupo de pesquisa; e poderiam ser objeto de um artigo, tamanha a fecundidade desses debates, no entanto, apresento apenas dois rápidos episódios. Alguns catingueirenses ficaram receosos com a nossa presença, associando-nos aos "fiscais de governo" que vinham destituí-los de seu direito ao benefício. Esse medo nos fala da precariedade histórica da garantia dos direitos sociais, que são entendidos como se pudessem, ao sabor de qualquer evento, serem revogados. Outro evento diz respeito a ajuda de custo que os pesquisadores deram às famílias, como forma de recompensá -los pela gentileza em nos receber. No entanto, o dinheiro foi rapidamente isento de seu teor mercantilista na medida em que foi usado para comprar 
"gentilezas" para o próprio pesquisador, como bolo, refrigerante, presentes, etc., num estonteante exemplo do segundo movimento exigido pela dádiva, segundo Marcel Mauss (1974) .

Catingueira, o município escolhido para a realização da pesquisa, é uma cidade pequena, com 4.812 habitantes segundo o Censo 20I0, Índice de Desenvolvimento Humano Municipal (IDHM) de 0,56 segundo Programa das Nações Unidas para o Desenvolvimento (PNUD) 2000, localizada no semiárido do Estado da Paraíba, no Alto-Sertão; cuja população, com raízes camponesas, divide-se entre a zona urbana e a zona rural, chamada de "sítios". Um contingente populacional estimado de 2.992 pessoas, ou seja, $62 \%$ da população5 é beneficiário do Programa (foram beneficiadas 8I3 famílias no mês de setembro de 20II), junte-se a isso a baixa monetização da região, e temos a constatação de que os efeitos do $\mathrm{PBF}$ podem ser ali mais facilmente observados, em comparação às cidades de médio e grande porte, aspecto também ressaltado pelo Relatório Executivo do Centro de Desenvolvimento e Planejamento Regional da Universidade Federal de Minas Gerais (CEDEPLAR) (2007). Do total de I.I9o famílias cadastradas, I.I5I contam com renda per capita mensal de até I/2 salário mínimo, o que as caracteriza como extremamente pobres. Do ponto de vista da economia local, as famílias sobrevivem através da agricultura de subsistência, pequenos comércios, empregos na prefeitura e benefícios, como o PBF e as aposentadorias.

\section{Resultados e discussão}

Concentramos nosso foco na questão da escola, na medida em que a continuidade dos estudos é o que garante o recebimento do benefício, para a população pesquisada.

Embora o dinheiro seja endereçado pelo governo às mães, foi observado que elas priorizam as crianças no momento das compras, mas também

5 Calculado a partir da Média de Pessoas por Domicílio (Censo IBGE, 2010) (3,68), do número de habitantes e de famílias beneficiadas. 
transferem diretamente parte do dinheiro às crianças. Não é incomum que a criança tenha a senha de acesso ao recurso e esteja habilitada pela mãe a retirá-lo. Quanto aos valores, as mães geralmente repassam de $\mathrm{R} \$ 0,25$ a $\mathrm{R} \$ 2,00 / \mathrm{R} \$ 5,00$ para as crianças pequenas e até $\mathrm{R} \$ 15,00 / \mathrm{R}$ \$20,00 para os adolescentes. Isto funciona como incentivo à escolarização e é uma forma de fazer justiça para com aquela criança que vem se esforçando nos estudos. Vale destacar, como faz Rego (2008), que a constância do recebimento, o que possibilita o planejamento familiar, é um aspecto muito ressaltado pelas famílias beneficiadas e, segundo Hanlon et al (20IO), essencial para que as transferências de renda sejam de fato políticas de desenvolvimento e não apenas assistencialistas.

Se o benefício é da família, por que as crianças são priorizadas? É uma pergunta importante a ser respondida. Em que pese a crescente importância das crianças na vida familiar, como já destacado, a população local parece lançar mão da historicidade das políticas sociais a fim de dotar ao benefício seu destino. Embora os gastos com o benefício do PBF não sejam tutelados pelo governo - o que representa, segundo Lavinas \& Barbosa (2000), um avanço em relação aos outros programas sociais no Brasil, como o Vale-Gás, o Fome-Zero etc. -, o PBF parece ter sido assimilado a partir da prioridade às crianças, parcialmente explicado pela sua semelhança com e procedência do Programa Bolsa Escola (PBE). Parece-nos então que, do ponto de vista nativo, o PBF é entendido como uma continuidade do seu antecessor, o PBE, e nesse sentido, é importante lembrar que o PBE constituía-se em um recurso destinado exclusivamente às crianças. Além disso, o PBF utiliza-se da condicionalidade escolar como forma de garantia do benefício, o que acaba por enfatizar o papel das crianças e dos adolescentes no recebimento do dinheiro.

O PBF traz como prerrogativa fundamental a escola, como primeiro compromisso das crianças. Em consonância com os ideais modernos (ARIÈS, I98I), para o PBF lugar de criança é na escola. Isso se dá através da condicionalidade escolar, que obriga as crianças de 6 a 15 anos de idade a uma frequência escolar mínima de $85 \%$ da carga horária e aos adolescentes 
de I6 e I7 anos de idade a uma frequência escolar mínima de 75\% da carga horária.

Embora a escola já estivesse presente no município para a geração das mães, a valorização dos estudos por parte da família, principalmente das meninas, não era largamente observada. Somava-se, para a geração das avós, todavia, a escassez de escolas no município o que representava um duplo impedimento à escolarização: escassez de escolas e falta de valorização dos estudos por parte da família. Para as crianças dos sítios, principalmente os grandes deslocamentos necessários para se chegar à escola mais próxima eram suficientes para inviabilizar o estudo formal. A falta de incentivo das famílias foi mais observada no caso das mulheres, que ouviam de seus pais que mulher não precisava aprender a ler e escrever, alardeando os perigos morais da atividade. Embora mesmo no caso dos homens, poucas foram as famílias entrevistadas em que os pais incentivavam a escolarização. (PIRES; JARDIM, 20I4)

Hoje o acesso à escolarização é entendido como completamente diferente dos tempos das avós/avôs e das mães/pais, ressaltando-se a facilidade de acesso à escola e à escolarização e os avanços alcançados. Uma mãe (40 anos) de dois adolescentes, quando entrevistada, nos afirmou que sempre aconselha seus filhos a estudarem, dizendo-lhes:

\section{[...] estudem! Porque boje é muito fácil, o governo até paga para vocês estudarem.}

Do ponto de vista do Ministério do Desenvolvimento Social e Combate à Fome MDS, espera-se que a obrigatoriedade da frequência escolar como forma de garantir o recebimento do benefício seja capaz de motivar as famílias a mandarem suas crianças para a escola, mesmo no caso daquelas famílias que não valorizam os estudos, evitando que as crianças sejam assimiladas precocemente e precariamente ao mercado de trabalho. Com olhos no futuro, espera-se que uma vez na escola, às crianças seja garantida uma melhor empregabilidade quando na idade adulta; assim 
replicando a ideia de que lugar de criança é na escola para as próximas gerações e rompendo, por fim, o círculo vicioso da pobreza que vem afetando várias gerações de famílias pobres, que pode ser pensada a partir da formulação:

Figura I - Ciclo Intergeracional da Pobreza

\section{baixa escolarização}

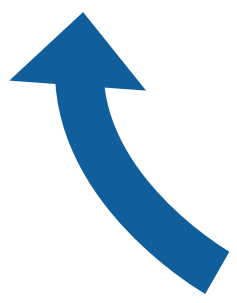

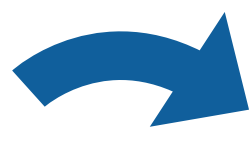

\author{
empregabilidade \\ precária ou \\ inexiste
}

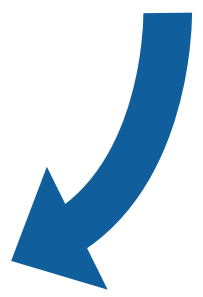

pobreza

Fonte: Elaboração do autor.

As famílias priorizam o consumo infantil e realizam o repasse financeiro direto para a criança na medida em que entendem que a condicionalidade escolar é a que, de fato, conta para o recebimento do benefício, enquanto as condicionalidades ligadas à saúde são mais entendidas como direito, na medida em que não resultam em punição (suspensões ou cortes). $\mathrm{O}$ controle da frequência escolar é bastante rígido e, de fato, leva à suspensão e ao corte do benefício, ao passo que no município ninguém tem conhecimento de benefícios suspensos em função do não cumprimento das condicionalidades da saúde. Entretanto, crianças e adultos conhecem 
pessoas que tiveram seu benefício suspenso ou cortado em função do não comparecimento ao colégio ou por erro no envio dos dados municipais escolares. (PIRES, 20I4)

$\mathrm{Na}$ cidade pesquisada, a relação do PBF com a escola é tão evidente que uma criança (Demerson, Io anos) chegou a dizer que o dinheiro do PBF passava pela professora: o governo tira o dinbeiro do banco, o banco manda para professora. Uma menina de io anos de idade, Fabíola, quando solicitada que desenhasse sobre o PBF desenhou de fato $A$ escola do bolsa familia, como podemos apreciar:

Figuras 2 - Escola do Bolsa Familia, de Fabiola, io anos

\section{Ea Errcala da borra familia}

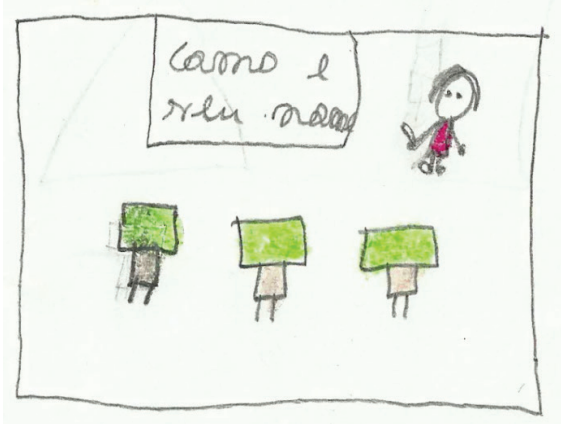

Uma vez que associam o benefício à escola, quando perguntadas de quem é o benefício, as crianças não hesitam em requerê-lo. Nildo e Paloma, ambos com II anos de idade, concordam quando foram perguntados De queméo beneficio?:

Nildo: Eu digo que é a criança que recebe.

Pesquisadora Patrícia: Por quê?

Nildo: Porque ela estuda. 
Paloma: Se é ela que estuda aí tem que receber.

Nildo: É porque ela tem que receber se é ela que está estudando.

Para isso, as crianças lançam mão da linguagem dos direitos, porque entendem que é o estudo que garante o benefício. Em foco, Lucas (II anos) e Silvana (I2 anos):

Lucas: É importante o Bolsa Família.

Pesquisadora Patrícia: Porque tu acha que é importante?

Lucas: Porque eles devem dá, por que nós estudamos.

Silvana: Nós estudamos e temos o direito de receber.

Pesquisadora Flávia: Então, toda criança que estuda tem o direito de receber?

Silvana: Tem.

Um dos problemas dos Programas de Transferência Condicionada de Renda (PTCR), como o PBF, é a necessidade de comprovação da pobreza familiar, o que segundo Suplicy (2007), leva a estigmatização do pobre. A ideia de uma renda básica da cidadania, como ocorre no Alaska, Estados Unidos, em que todos os cidadãos, independente da renda comprovada, recebem uma porcentagem do PIB, tem como fim prevenir esse estigma. Todavia, em Catingueira, para as crianças, essa estigmatização não ocorre. Segundo elas, o recebimento do PBF está condicionado à frequência escolar e não à renda da família. Para elas, não importa se a família é rica ou pobre, desde que tenha crianças na escola, o recebimento do benefício deveria ser garantido. De forma que, para as crianças, o Programa não estigmatiza o pobre. Veja o extrato do grupo focal em que falam Lucas e Nildo, ambos com II anos:

Pesquisadora Patrícia: E tem alguém rico aqui em Catingueira que recebe o Bolsa Família? 
Lucas: Tem.

Pesquisadora Patrícia: Tem?

Lucas: Eu acho que tem.

Pesquisadora Patrícia: Porque tu acha que tem?

Lucas: Eu acho que tem. Porque as que filhas dele estudam, aí tem que receber também.

Nildo: Agora não receba?

Se é a frequência escolar que garante o benefício, logo, entende-se que as famílias sem criança em idade escolar não deveriam receber. Nathanaelly (Io anos) escreve:

\section{[...] Para as mães poderem receber o Bolsa Familia \\ todas as mães devem ter crianças, se não tiverem crianças não podem receber.}

Isso leva-nos a curiosa constatação de que a punição prevista no Programa incide apenas sobre as famílias com crianças em idade escolar. Em outras palavras, as famílias sem crianças em idade escolar não estão sujeitas à suspensão ou corte do benefício, uma vez que não se submetem à condicionalidade escolar. Esta consideração atiça o debate em torno da legitimidade do caráter punitivo do direito à escola, agora de um outro ponto de vista - já que a punição é prerrogativa apenas de um tipo de família. Aqui temos uma oportunidade para pensar a legitimidade das condicionalidades e o debate em torno dos direitos humanos e de cidadania que elas suscitam. (DINIZ, 2007; SILVA, 2007; ZIMMERMAM, 2006) As condicionalidades são, de fato, sujeitas a controversas, afinal, o

\footnotetext{
6 Referindo-se ao dono do maior estabelecimento comercial da cidade.

7 Interjeição que, aproximadamente, quer dizer: "Como não receberia?"
} 
acesso à escola é um direito. Além disso, concordo com Hanlon e colaboradores (20IO) quando afirmam que os pobres querem ver seus filhos escolarizados, mas lhes faltam dinheiro para garantir esse sonho: transporte escolar, uniforme, calçados, material escolar resultam em despesas. Os autores afirmam que não há nenhuma evidência de que as condicionalidades de fato funcionem. (HANLON; BARRIENTOS; HULME, 20IO) Segundo eles, é acesso ao dinheiro que permite que as famílias enviem seus filhos para a escola, tornando a condicionalidade desnecessária. Todavia, sendo uma condicionalidade que incide apenas em um tipo de família, aquelas com crianças em idade escolar, o debate em torno desse aspecto do programa merece um esforço de pesquisa ainda mais detalhado.

\section{Conclusões}

Nesse artigo realizamos uma breve apresentação de alguns dos resultados de pesquisas sobre o $\mathrm{PBF}$ focando o ponto de vista das crianças, embora a presença dos adultos se fizesse evidente, e enfatizando como a frequência escolar engendra moralidades dentro das famílias.

Sabendo que o recebimento do PBF é direito das crianças e sabedora de que são elas quem "trabalham", ou seja, estudam pela manutenção do benefício, as crianças estão em condições de negociar, principalmente com a mãe, detentora do direito ao recebimento do benefício, suas necessidades e seus pequenos luxos, sob a ameaça de não ir à escola. Nesses casos em que a criança não queira ir ao colégio ocorre uma negociação entre mãe e filho(a). Os termos da negociação podem ser dinheiro, um pedaço maior de carne, a liberação das atividades domésticas a que a criança é responsável, a escolha do prato a ser preparado, um ovo no cuscuz, uma peça de vestuário, liberdade para ir à lan-bouse ou visitar amigos, dentre outros. Se esses mimos não são suficientes, a mãe, por sua vez, ressalta a necessidade da frequência escolar visando o recebimento do benefício, colocando a responsabilidade do sustento familiar e da própria criança, nas mãos do aluno. A ameaça, no sentido de "se vocên não for à escola vai faltar 
o alimento para todos, especialmente para você”, parece ser o suficiente para convencer a criança da necessidade de frequentar o colégio. Observamos, então, uma responsabilização da criança pela manutenção do benefício. Responsabilidade a qual ela tem conhecimento e abraça.

Como foi dito, mesmo não sendo claramente direcionado a elas, as crianças requerem parte do benefício da família, em um claro exercício político. (PIRES; FALCÃO; SILVA, 20I4) Os membros familiares, notadamente a mãe, reconhecem a legitimidade nesse pleito, uma vez que estudar é entendido como trabalho pesado, cansativo. Na verdade, parece-nos que é justamente porque a escola é entendida como trabalho pelos membros familiares que, por isso, está sujeito à recompensa. Dessa for$\mathrm{ma}$, a elas parecem ser reconhecidos direitos individuais à riqueza familiar porque entende-se que as crianças são essenciais para a sua produção; reverberando as ideias do economista norueguês Jens Qvrotrup (2008) quando afirma que o Estado e a sociedade devem reconhecer que estudar é a forma de participação das crianças na divisão social do trabalho nas economias nacionais das sociedades contemporâneas e, portanto, elas têm direito legítimo a gozar da riqueza da nação, por exemplo, exigindo boas escolas, adaptação das cidades às suas necessidades, que sejam ouvidas sobre políticas públicas que as afetam diretamente e naquelas que dizem respeito à sociedade de modo geral, etc. Nesse sentido, esse exercício político das crianças refere-se, no curto prazo, ao atendimento de demandas imediatas, advindas da possibilidade de aquisição de novos bens de consumo pelas famílias e pelas crianças mesmas. Entretanto, não temos condições ainda de vislumbrar a quebra no círculo vicioso da pobreza em função de um reposicionamento do lugar da escola para as crianças e os adultos. Embora seja verdadeiro que as crianças estão na escola - o que as estatísticas mostram -, isso não garante que elas estejam sendo educadas ou que conseguirão realmente quebrar o círculo vicioso da pobreza. $\mathrm{Na}$ verdade, tememos pelo estado precário das escolas e da educação públicas.

Muitos são os campos de investigação abertos pelas pesquisas sobre o $\mathrm{PBF}$. Esperamos ter mostrado com esse texto a importância de incluir as 
crianças nas nossas pesquisas, como sujeitos e interlocutores legítimos. $\mathrm{O}$ conhecimento que as crianças têm do PBF é acurado e crítico. Se elas são afetadas pelas políticas sociais, nada mais coerente que ouvi-las.

\section{Referências}

ARIÈS, P. História social da criança e da familia. Trad. Dora Flaksman. 2. ed. Rio de Janeiro: Livros Técnicos e Científicos, I98I.

BENJAMIN, T. Brebotos e burugangas: analisando o "empoderamento" infanto-juvenil no Sertão Paraibano. CAOS UFPB, João Pessoa, v. I, n. I5, p. 3I-36, mar. 2010.

DINIZ, S. Critérios de justiça e programas de renda mínima. Revista Katálysis, Florianópolis, v. IO, n. I, p. IO5-II4, 2007.

FAVRET-SAADA, J. "Ser afetado". Cadernos de Campo, São Paulo, Ano I4, n. 13, p. 155-163, 2005.

FEITOSA, P. H. F. "O pobre codificado No Programa Bolsa Família e no Cadúnico”. O Cidadão Codificado: a digitalização da cidadania em bancos de dados de interesse público. 20IO. 247 f. Dissertação (Mestrado Engenharia de Sistemas e Computação) - COPPE, Universidade Federal do Rio de Janeiro, Rio de Janeiro, 2010.

GEERTZ, C. Do ponto de vista dos nativos: a natureza do entendimento antropológico. $O$ saber local. Novos ensaios em antropologia interpretativa. Petrópolis, RJ: Editora Vozes, 2002. p. 85-I07.

HANLON, J.; BARRIENTOS, A.; HULME, D. Fust give money to the poor: the Development Revolution from the Global South. Sterling: Kumanian Press, 2010.

JAMES, Allison. Giving voice to children's voice: practices and problems, pitfalls and potentials. American Antbropologist, Washington, D.C. v. Io9, n. 2, p. 26I-272, 2007. 
LAVINAS, L.; BARBOSA, M. L. de O. Combater a pobreza estimulando a freqüência escolar: o estudo de caso do Programa Bolsa-Escola do Recife. Dados, Rio de Janeiro, v. 43, n. 3, p. 447-477, 2000.

MAUSS, Marcel. "Ensaio sobre a dádiva - Forma e razão da troca nas sociedades arcaicas”. Sociologia e Antropologia. São Paulo: EPU, 1974. v. 2. MEDEIROS, Marcelo; BRITTO, Tatiana and SOARES, Fábio. Transferência de renda no Brasil. Novos estudos - CEBRAP, Campinas, n.79, p. 5-2I, 2007.

MONNERAT, G. L. et al. Do direito incondicional à condicionalidade do direito: as contrapartidas do programa Bolsa Família. Ciência \& Saúde Coletiva, Rio de Janeiro, v. I2, n. 6, p. I453-I462, 2007.

NOGUEIRA, S. G.; PIRES, F. F. “Corram riscos!” - Entrevista com o Professor Otávio Velho. Revista Antbropológicas, Recife, v. 2I, p. 329-34I, 2010. PIRES, F. F. Child as family sponsor: An unforeseen effect of Programa Bolsa Familia in northeastern Brazil. Childhood, Copenhagen, v. 2I, p. I34-I47, 2014. PIRES, F. F. ; SANTOS, P. O. S. dos ; SILVA, K. J. Elas decidem? Analisando o papel familiar da mulher a partir do Programa Bolsa Família. CAOS. Revista Eletrônica de Ciências Sociais, João Pessoa, v. 17, p. I08-I19, 20 II.

PIRES, F. F. Comida de Criança e o Programa Bolsa Família: moralidade materna e consumo alimentar no semi-árido. Política \& Trabalbo, João Pessoa, v. 38, p. 123-135, 2013.

PIRES, F. F. ; FALCÃO, C. R. ; SILVA, A. L. da. O Bolsa Família é direito das crianças: Agência Política Infantil no semi-árido Nordestino. Teoria \& Sociedade, Belo Horizonte, v. 22, p. I4I-I67, 20I4. Disponível em: <http://www.fafich. ufmg.br/revistasociedade/index.php/rts/article/view/I42/ro7>.

PIRES, F. F.; JARDIM, G. A. da S. Geração Bolsa Família: educação, trabalho infantil e consumo na casa sertaneja (Catingueira/PB). Revista Brasileira de Ciências Sociais, São Paulo, v. 29, p. 99-II2, jun. 2014.

PIRES, F. F.; NOGUEIRA, S. G. Sociologia e Antropologia - Entrevista com Professor Otavio Velho. Política \& Trabalbo, João Pessoa, v. 34, p. 23I-235, 201 I. QVORTRUP, Jens. Childhood in the Welfare State. In: JAMES, A.; JAMES, A. European Cbidbood. Cultures, Politics and Cbildhoods in Europe. London: Palgrave Macmillan, 2008. 
REGO, W. G. D. L. Aspectos teóricos das políticas de cidadania: uma aproximação ao Bolsa Familia. BIB. Revista Brasileira de Informação Bibliográfica em Ciências Sociais, São Paulo, v. 73, p. I47-I85, 2008.

SANTOS, P. O. S. dos. A invenção da infância: o programa bolsa família e as crianças da comunidade de Feira Nova (Orobó PE) no agreste pernambucano. 20I4. Dissertação (Mestrado em Antropologia) - Universidade Federal da Paraíba, João Pessoa, 2014.

SANTOS, Patrícia Oliveira Santana dos. Deixa eu falar! Uma análise antropológica do Programa Bolsa Família a partir das crianças beneficiadas do alto sertão paraibano. Trabalho de Conclusão do Curso (Graduação em Ciências Sociais), Universidade Federal da Paraíba, João Pessoa, 20 II.

SARMENTO, Manuel. "Sociologia da Infância: Correntes e Confluências”. In. Estudos da Infância. Educação e Práticas Sociais. Petrópolis, RJ: Ed. Vozes, 2008.

SILVA JARDIM, G. A. da. A casa sertaneja entre geraç̃es: os impactos do Programa Bolsa Família na cidade de Catingueira - PB. 20ıo. Trabalho de Conclusão do Curso (Graduação em Ciências Sociais) - Universidade Federal da Paraíba, João Pessoa, 2oı̀ob.

SILVA JARDIM, G. A. da. Reflexões antropológicas a partir de uma política pública para crianças. CAOS - Revista Eletrônica de Ciências Sociais, João Pessoa, n. 15, p-. 37- 45, mar. $2010 a$.

SILVA, A. L. O direito da infância num universo adultocentrado: possíveis conflitos de interesses na interpretação do ECA por crianças e adultos. In: CONGRESSO LUSO AFRO BRASILEIRO DE CIÊNCIAS SOCIAIS: DIVERSIDADE E DESIGUALDADES, 9., 20II, Salvador. Anais... Salvador: Uiversidade Federal da Bahia, 20II.

SILVA, A. L. ; PIRES, F. F. Direitos da Infância: crianças e adultos entendem a mesma coisa?. In: CONGRESSO INTERNACIONAL DA ASSOCIAÇÃO LATINO-AMERICANA DE SOCIOLOGIA, 28. 20II, Recife. Anais...

Recife: Universidade Federal de Pernambuco, 20 II.

SILVA, J. K. R. da. “Eu Compro Tudo De Pelota!”: O Programa Bolsa Família e a expansão do consumo infantil em Catingueira/ PB. Trabalho de Conclusão do Curso (Graduação em Ciências Sociais) - Universidade Federal da Paraíba, João Pessoa, 20II. 
SILVA, M. O. da S. e. O Bolsa Família: problematizando questões centrais na política de transferência de renda no Brasil. Ciência \& Saúde Coletiva, Rio de Janeiro, v. I2, n. 6, p. 1429 - I439, 2007.

SOARES, F. et al. Programas de Transferência de Renda no Brasil: impactos sobre a desigualdade e a pobreza.Centro Internacional de Pobreza (IPEA/PNUD). 2006. Disponível em: <http://www.anpec.org.br/encontro2oo6/artigos/ Ao6Ai56.pdf>. Acesso em: 7 nov. 2016.

SOUZA, E. do N. As crianças e o Programa Bolsa Familia em Catingueira (PB): uma reflexão antropológica da condicionalidade escolar a partir do ponto de vista das crianças. 20II. Trabalho de Conclusão do Curso (Graduação em Ciências Sociais) - Universidade Federal da Paraíba, João Pessoa, 20 II.

SUÁREZ et al. O Programa Bolsa Família e o enfrentamento das desigualdades de gênero - o desafio de promover o reordenamento do espaço doméstico e o acesso das mulheres ao espaço público. Relatório Compreensivo de Pesquisa. Apresentado ao Ministério do Desenvolvimento Social e Combate à Fome (MDS) e ao Department For International Development (DFID) Por agende ações em gênero cidadania e desenvolvimento, 2006. Não publicado.

SUPLICY, E. M. O direito de participar da riqueza da nação: do Programa Bolsa Família à Renda Básica de Cidadania. Ciência \& Saúde Coletiva, Rio de Janeiro, v. I2, n. 6, p. 1623-1628. nov./dez., 2007

TOREN, Christina. Mind, materiality and history: explorations in Fijian ethnography. London: Routledge, I999.

ZIMMERMANN, C. R. Os programas sociais sob a ótica dos direitos humanos: o caso do Bolsa Família do governo Lula no Brasil. Sur, Rev. int. direitos buman, São Paulo, v. 3, n. 4, p. I44-159, 2006. 


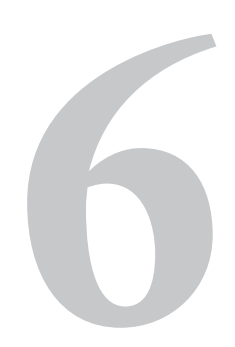

\title{
Homossexualidades como processo educativo e construção discursiva
}

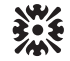 \\ Anderson Ferrari
}

\begin{abstract}
No Ocidente, não temos a arte erótica. Em outras palavras, não se ensina a fazer amor, a obter o prazer, a dar prazer aos outros, a maximizar, a intensificar seu próprio prazer pelo prazer dos outros. Nada disso é ensinado no Ocidente, e não há discurso ou iniciação outra a essa arte erótica senão a clandestina e puramente interindividual. (FOUCAULT, 2006, p. 6I)
\end{abstract}

Aceitar a convites para pensar o campo da educação e suas relações com as sexualidades me coloca num lugar de problematização e, nesta linha de condução, me aproxima de Michel Foucault quando diz que seus trabalhos se vinculam a história do pensamento. (MARSHALL, 2008) 
Problematizar é dar um passo atrás para colocar sob suspeita nossas formas de pensar e agir. Por que penso o que penso? Que pensamentos organizam minhas ações? Questionar o pensamento e ação é um ato de liberdade. "É a liberdade de serparar-se do que se faz, é o movimento pelo qual alguém se separar do que faz, de forma a estabelecê-lo como um objeto de pensamento e a refletir sobre ele como um problema”. (MARSHALL, 2008, p. 3I) Trabalhar no encontro entre educação e sexualidades é trabalhar com a perspectiva da problematização. educação, neste sentido, diz de algo mais abrangente que os processos de ensino-aprendizagem, o cotidiano escolar, os conteúdos, a formação docente, os currículos. Educação diz da constituição dos sujeitos e suas formas de pensar e agir, diz da relação entre a construção dos sujeitos e a história do pensamento.

Por isso a escolha a epígrafe, em que Foucault afirma numa ato provocativo para os educadores e para a Educação: "No Ocidente, não temos a arte erótica. Em outras palavras, não se ensina a fazer amor, a obter o prazer, a dar prazer aos outros, a maximizar, a intensificar seu próprio prazer pelo prazer dos outros”. (FOUCAULT, 2006, p. 6I) Essa afirmação também diz das escolas e do que fazemos nela. Mas diz, sobretudo, das relações que vamos construindo entre nós mesmos, com os amigos e as amigas, com os filhos e as filhas, nos nossos relacionamentos. Foucault continua: “[...] não há discurso ou iniciação outra a essa arte erótica senão a clandestina e puramente interindividual”. (FOUCAULT, 2006, p. 6I) É essa forma clandestina e interindividual que quero tomar como provocativa para pensar o ato educativo de educar o outro. Para isso, quero tomar um acontecimento entre amigos para nos convidar a pensar esses "novos" tempos em que estamos vivendo e que nos coloca novos desafios para pensar as homossexualidades, os desejos, o governamento das identidades.

Há algum tempo atrás, um amigo me apresentou um rapaz de mais ou menos 26 anos, culto, bonito e um pouco tímido, que ele havia conhecido numa sauna gay. Meses depois esse mesmo amigo me contou um pouco surpreendido que esse rapaz não queria mais encontros sexuais com ele 
porque havia decidido investir em relacionamentos fugazes, sem compromisso e limitados ao sexo. Para isso ele havia criado um $\log ^{\mathrm{I}}$ na internet contando suas aventuras sexuais e assumindo uma nova postura diante da homossexualidade: só queria parceiros com órgãos sexuais acima de 20 $\mathrm{cm}$ e que se deixassem filmar na relação sexual. Havia se transformado em TaradaoZS. Fiquei muito interessado por esse movimento que conjuga homossexualidades e internet. Que novos arranjos são possíveis a partir dessa tecnologia? Que novas formas de ser estão em jogo? Que novas homossexualidades são construídas neste espaço virtual? Quem é esse novo homossexual que organiza um blog com suas filmagens? Quem são os seguidores deste blog que exercem suas fantasias, suas homossexualidades e seus encontros a partir da internet? Questões que dialogam com o meu campo de interesse sobre os processos de subjetivação, principalmente aqueles ligados as homossexualidades masculinas. Como eu tinha o e-mail pessoal do rapaz, dono do blog, entrei em contato com ele dizendo que sabia desta novidade e que estava interessado em conversar a respeito desse processo, visto que dizia do meu campo de investigação. Alguns dias depois recebi a resposta de que ele não queria falar sobre isso, não queria elaborar um raciocínio sobre o que estava fazendo, queria somente transar e construir o blog.

Uma resposta que me levou a pensar ainda mais nesta experiência, que me levou a pensar a mim mesmo. Porque eu queria escrever sobre isso? $\mathrm{O}$ que o Taradao $Z S$ me questiona é se há necessidade de falar sobre isso. Ele não está interessado em transformar o que faz em conhecimento, ele está interessado em vivenciar, em experimentar e isso basta. Até que ponto o meu interesse está inscrito naquilo que Foucault (1988) chama atenção e que nos organiza desde a modernidade que é essa "vontade de saber"? Como estamos capturados por essa necessidade de transformar o sexo em conhecimento. Convencido com a resposta do TaradaoZS, abandonei o

${ }^{1}$ Disponível em: <http://TaradaoZS.blogspot.com.br/search/label/contos\%20de\%20 TARADAOZS>. Aceso em: 27 jan. 2013.. 
projeto de escrever o artigo e resolvi dar uma olhada, pela primeira vez, no blog. É um artefato muito bem construído, com imagens, filmes em que TaradaoZS aparece transando com os seus parceiros (em todos os vídeos os envolvidos aparecem sempre protegidos com máscaras ou em posições em que não é possível ver seus rostos). Também fazem parte do blog, contos, quadro de seguidores, um sistema de avaliação do desempenho sexual nos vídeos, há fotos enviadas pelos leitores se propondo a transarem com TaradaoZS, todas elas aparecem o corpo do pescoço até as coxas garantindo, pela imagem, cumprirem a exigência de terem um órgão sexual de no mínimo $20 \mathrm{~cm}$. No entanto, ainda com o ensinamento de que não há necessidade de produzir uma narrativa sobre si e que não queria falar sobre o que estava fazendo, me surpreendi com uma parte do blog em que Taradao $Z S$ fala de si, revela quem é.

Tomado por esta "surpresa", retomei o projeto de escrever o artigo que agora se apresenta, considerando o blog como campo de investigação, trabalhando com as informações, imagens, contos e outras informações que o sujeito escolhe para ser construída, que fornece ao leitor, controlando aquilo que o outro deve saber, construindo uma imagem de si a partir do que elege como narrativa. Esse não é um processo isolado. Muito pelo contrário. É cada vez mais comum blogs e processos de subjetivação semelhantes. Dois movimentos que se relacionam. Por um lado nós temos pessoas dispostas a construírem páginas na internet em que falam de si, produzem imagens de si relacionadas às orientações e práticas sexuais. Por outro lado, há também pessoas que não constroem essas páginas, mas participam do mesmo processo, na medida em que seguem essas personagens, exercitam suas homossexualidades pela internet, encontram com essas personagens mediadas pela máquina. Me parece possível pensar que o computador se transformou em um objeto de desejo, algo que encontro prazer, que me ensina a ter prazer e a exercer as homossexualidades.

É esse movimento que está em processo de construção - a expressão das homossexualidades na internet - que quero tomar como foco de análise deste artigo. Mais do que isso percebo que essas expressões também se cons- 
tituem como uma maneira de ser, estando intimamente relacionada ao que estou chamando de "'novas' homossexualidades". Neste sentido, estou considerando as homossexualidades como processo em constante construção discursiva e cultural, o que envolve hoje os mecanismos tecnológicos em que podemos investir em diferentes maneiras de ser, evidenciando o caráter fluído das identidades. Atualmente, os modos de produção material e simbólica que envolvem as identidades homossexuais estão atravessados pelas novas tecnologias, sobretudo pela internet, que gera novas arquiteturas, relacionamentos e negociações que impactam o comportamento das pessoas e da sociedade. A internet penetra as dobras sociais, influenciando assim as formas de relacionamento entre os sujeitos, produzindo processos de subjetivação. Esse novo espaço de circulação e de produção das identidades homossexuais vai se constituindo como um novo espaço de valores e representações das homossexualidades dependentes cada vez mais da disseminação de uma cultura visual e digitalizada que determina, consequentemente, configurações inéditas das relações dos sujeitos com o se entorno e consigo mesmo. Para esse trabalho quero me debruçar e problematizar os sujeitos que se consideram homossexuais e que se colocam, sobretudo na internet. Especificamente quero tomar para problematização o blog criado pelo sujeito identificado como TaradaoZS, que textualmente diz que só se relaciona a partir da internet, conseguindo parceiros através do seu blog e da publicitação de suas relações sexuais. A exigência para os encontros sexuais é deixar-se filmar.

Neste sentido estou chamando de "'novas homossexualidades" essas relações que são mediadas pelo computador. As homossexualidades não se constituem somente pelo desejo (FERRARI, 2005), nem tampouco passam pela obrigatoriedade da prática sexual. Assim sendo, teremos homens que sentem desejos por outros homens, mas esse fato não faz deles homossexuais. Da mesma forma que teremos homens que sentem desejos por outros homens e que nunca vivenciaram esses desejos e que se sentirão homossexuais. A construção das homossexualidades diz que o desejo é um processo de investimento num tipo de enquadramento que vamos construindo e que vamos assumindo na medida em que nos depa- 
ramos com aquilo que o social diz que somos e que o desejo é apenas uma parte deste processo. Então, pensar que esse processo de aproximação e distanciamento das homossexualidades pode se dar via computador, que a experiência e vivência das homossexualidades pode ocorrer via internet, me parece algo "novo". No entanto, um "novo" atravessado por outros processos que são recorrentes, tais como a necessidade de falar de si, misturada atualmente com a necessidade de mostrar, produzir imagens para além das narrativas de si. Assim, reforçando meu interesse por esse processo como foco de análise, quero concentrar minha escrita em dois pontos. Um primeiro ponto diz da "narrativa de si" e como ela implica na construção dos sujeitos, tanto daquele que fala de si quanto dos outros que são construídos a partir dessa narrativa. E, um segundo ponto, é como esse processo de narrativa que vai de um para o outro, constrói "novas" homossexualidades?

\section{Quem é TaradaoZS?}

O título desta parte é uma reprodução do que encontrei no blog e que em grande parte responde aos meus interesses iniciais de saber quem é esse sujeito que investe neste tipo de artefato cultural? Quais são as suas procuras? Um título que em si já é revelador, visto que busca dizer de si, responder a pergunta "quem sou eu", e que o Taradao $Z S$ assume como necessária. Se negou a minha proposta de entrevista, porque elabora um texto com esse? Talvez possamos dizer que negou porque entrei em contato com a pessoa e não com a personagem, que utilizei um e-mail pessoal para falar de um outro sujeito, que associei duas instâncias de subjetividade que não era para ser confundida. O rapaz não queria falara sobre o Taradao $Z S$, assim como o Taradao $Z S$ não quer falar da sua vida para além da internet. Ambos não querem ser entrevistados, ambos querem controlar o que vão falar, quando irão falar e se vão falar. É uma forma de controle sobre si.

\section{Quem é TaradaoZS}

Não uso drogas, bebo socialmente e sexo só com camisinba SEMPRE, não tem conversa. Diferente do que muita gente pensa, não transo com um cara por dia. Fá passei por essa fase e confesso que aproveitei muito... 
O problema de fuder desenfreadamente é que você vende a sua alma e se torna escravo do sexo. Nada te satisfaz, você fica insaciável e o vazio fica cada vez maior. Além de vocêperder o foco, perde a noção de que o tempo está passando e nada está sendo feito.

Hoje, embora o sexo seja em menor frequência, continuo dando muito, e para paus cada vez mais exagerados. O maior que já peguei tinba uns 30 centímetros, um jamaicano que me pegou num quarto de botel em Copacabana e literalmente acabou comigo. Era grande, grosso e duro. Fiquei sem poder sentar no dia seguinte, não élenda. O maior número de bomens numa noite? Io. Todos dotados. Um fã que sempre quis me ver dando, agilizou uma festa na sua casa com cerveja liberada, chamou Io dotados, todos com mais de 21 cm de dote e fui a comidinba deles. Só não filmei porque 2 deles não toparam. Morro de tesão sempre que me lembro disso, foi uma das melbores experiências sexuais que já tive, e olbe que foram muitas. $O$ melbor sexo de todos? Isso não existe. O meIbor é o que você ainda não fez, é o que babita a sua imaginação. Todos foram bons na sua totalidade, alguns bons até demais.

Quem sou eu? Eu sou você quando fecha a porta do quarto e liga o computador. Eu sou a sua intimidade, seus maiores fetiches e fantasias. Por esse motivo nunca mostro meu rosto e das pessoas que aparecem nos meus videos, para que tudo fique na sua imaginação. Assim você pode construir a sua realidade e fugir pra lá, esquecer do mundo, da chateação e dos problemas. Poderá encontrar-se consigo mesmo, resolver seus problemas internos enquanto se masturb a com prazer. Eu sou o rabudo que é arregaçado por qualquer dotadão sem compromisso, sem pudor, sem importar em saber o nome, sem culpa. Para os ativos, sou o pirocudo arregaçador, que pega um passivo pela cintura, mete na pressão, o arromba por completo e, em seguida o descarta junto da camisinba ou por quanto tempo durar o tesão. 
Resumindo, sou o que vocêe é, mas nunca terá coragem de assumir por medo, por preconceito ou rejeição.

Sou uma pessoa comum como qualquer outra, que trabalba, paga as contas, vive um dia de cada vez. Mas como todo ser bumano tenbo a minba válvula de escape para desabafar sobre as coisas da vida que não consigo por em ordem. Podem me julgar, dizer que é algo insano, promíscuo, sem valor próprio. Seja lá qual for a sua opinião sobre isso, pouco me importa. Se você vasculbar a vida de qualquer pessoa vai encontrar um podre, vai se deparar com algo que nunca imaginaria. Então esse é o meu podre que convivo muito bem. Tudo é válido desde que baja responsabilidade e não façamos mal a ninguém.

Na maioria dos casos, 60\% para ser mais específico, sou convidado pelos internautas para fazer os filmes. Recebo convites dos sites onde bospedo meus vídeos; através do msn; Skype; email e, principalmente, do meu blog. Faço uma préseleção: tem que ser masculino, dote acima de $21 \mathrm{~cm}$, e disposição pra meter, porque não brinco com sexo e tenho pavor a foda mal dada. Assim aprovado, trocamos fotos, cam, telefone e já marcamos a real. Os outros 30\% conbeço na rua, numa noite na lapa, na praia num dia ensolarado, num barzinbo qualquer, ou na própria cadeira do dentista. Por incrivel que pareça tenbo um radar aguçado e nunca errei ao conbecer um cara na rua e levar direto pra cama: sempre épauzudo. Existe uma pequena minoria que entra nos $10 \%$ que são garotos de programa que querem fazer videos comigo desde que não me cobrem nada, é claro, pra promoverem seus trabalbos, sites, blogs, exporem a figura... E existe também uma parcela dos fanáticos que fazem propostas com dinbeiro, ou mandam a passagem pra qualquer destino do mundo pra poderem fuder comigo, por puro fetiche. Essa última opção nunca aceitei por questões pessoais. Não tenbo a intenção de ganbar dinbeiro com meus vídeos, ou vender o corpo, faço tudo por prazer e satisfação pessoal. 
Filmo minbas fodas por vaidade sim, confesso que me gabo quando acesso minba caixa de e-mails e recebo incontáveis propostas pra filmar, comentários nos vídeos, mensagens, algumas de pessoas desaforadas que não têm a coragem de mostrar a cara, mas sei quem são e desejo muito que elas continuem falando mal e perdendo o tempo delas me julgando. A crítica, seja ela positiva ou negativa sempre causa impacto e dá ibope, portanto são todos benvindos.

A primeira vez que comecei a filmar tinba I9 anos, 6 anos atrás. Éramos 3 na foda, eu o único passivo, óbvio (não curto dividir pica, que isso fique bem claro). Tinba chegado de uma festa e estava com minba máquina fotográfica na cabeceira da cama quando um dos ativos a pegou e disse: nunca vi ninguém dar assim, vou registrar na sua própria câmera e quero que você assista quando chegar em casa. Fiquei maluco pelo vídeo, bati umas 40 punbetas e o postei num blog para agilizar na pegação. Não tinba muita paciência pra enrolação, ficar me exibindo na cam, boras incontáveis em sala de bate papo, perdendo tempo com gente desocupada. Então mandava o link da foda e em 5 minutos estava eu com um pirocão na boca. Depois disso uns caras se propuseram em filmar e a coisa foi tomando outra proporção. Hoje chegou ao ponto de somar quase 50 milhões de bits juntando os acessos em todo o mundo. Fá recebi propostas para mostrar o rosto em sites pornôs como Machofucker, fazer vídeos com atores pornôs consagrados, já até fiz uns que ainda não postei. Se jogar TaradaoZS no google verá que a internet tem seu poder e multiplicou meus vídeos em sites que nem imagino. Chegou ao ponto de existir uma galera que plagia meu trabalbo, se passa por mim... Sempre são desmascarados, tenbo um estilo próprio que inventei e isso me diferencia de qualquer outro. Não estou dizendo que sou o melbor ou pior, mas diferente.

Sempre fui muito fogoso, já procurei ajuda de psicólogos e disseram que era normal, que diminuiria com a idade. Será que eles se referiam após 
os 60 anos? Bom, é verdade que diminuiu um pouco sim, mas ainda tenho tesão de sobra e, vez por outra sobe a cabeca e me tira do eixo. Foi por isso que surgiu o nome Taradao e Zona Sul porque moro nessa região no Rio de Faneiro, portanto TaradaoZS era pra facilitar na pegação, pra saberem onde eu me localizava, embora não me impedisse de atravessar a cidade ou o estado se a pica valesse realmente a pena. Não sou um playboy da Zona Sul que vive a vida sem compromisso. Ninguém é da Zona Sul, a gente está na Zona Sul, amanba as coisas podem ser diferentes.

Quando vou parar? Ainda não sei, mas será em breve. Não será por namoro, casamento, ou porque alguém pediu. Sou bem resolvido e uma pessoa livre, acima de tudo. Estou disposto ao acerto de contas, e quando eu decidir terminar o farei por livre espontânea vontade. Pode ser amanhã, semana que vem ou daqui alguns anos.

Tenbo uma intenção subliminar nos meus filmes, tenbo projetos de ajudar a construir um mundo melbor (não preciso que você acredite nisso) e descobri que a pornografia me aproxima de todas as pessoas mesmo que elas não se identifiquem.

"Eu sou você quando fecha a porta do quarto e liga o computador": narrativa de si.

Recusar a entrevista e, ao mesmo tempo, responder a pergunta "quem sou eu?”, é recusar-se a ser produto de alguém, num exercício dele próprio - o TaradaoZS - escrever e se inscrever como personagem e resultado de sua narrativa. Ao final temos como um memorial em que ele justifica suas escolhas, diz quem é, recupera sua trajetória, memória num jogo de construção e compreensão de como se tornou o que é.

"Sou uma pessoa comum como qualquer outra, que trabalba, paga as contas, vive um dia de cada vez. Mas como todo ser bumano tenho a minha válvula de escape para desabafar sobre as coisas da vida que não consigo por em ordem. Podem me julgar, dizer que é algo insano, promíscuo, sem valor próprio”. Ao mes- 
mo tempo em que diz que é uma pessoa comum, como qualquer outra, o que o Taradao $Z S$ parece fazer é fortalecer que vivemos num mundo plural em que se multiplicam as experiências, as experimentações de forma que não podemos falar das homossexualidades como algo homogêneo, mas que essa homogeneidade cada vez mais dá lugar à heterogeneidade que nos compõe. Algo que dialoga com as novas tecnologias e esse mundo da cultura visual em que circulamos e nos apropriamos, de forma que essas mudanças têm tornado evidentes e introduzido inovações nos processos de subjetivação que incluem a produção de imagens e narrativas de si, a exposição e o intercâmbio dessas constituições, ou seja, a recomposição de quem somos diante do "outro", inclusive através dos perfis virtuais que trabalha com a fantasia, com o desejo e que não está no necessariamente ligada a comprovação da verdade. Não me interessa se o que está no blog é verdade, visto que trabalho e lido com a potencialidade do texto, da narrativa de si e das imagens como "verdadeiras" e, sobretudo, como algo que está a meu serviço, mexe comigo, me serve, me leva a encontros.

Sua prática de filmar e de evidenciar sua busca desenfreada por sexo é duplicada em sua narrativa, de forma que TaradaoZS ganha corpo pela escrita. No entanto, pela escrita de si via estabelecendo causalidades, explicações, justificativas. "Eu sou você quando fecha a porta do quarto e liga o computador. Eu sou a sua intimidade, seus maiores fetiches e fantasias. Por esse motivo nunca mostro meu rosto e das pessoas que aparecem nos meus vídeos, para que tudo fique na sua imaginação". A partir da forma de organizar sua narrativa, Taradao $Z S$ vai definindo sua identidade, sem fugir da relação entre identidade e sua "verdade". Sua verdade está nas relações sexuais. "Sempre fui muito fogoso, já procurei ajuda de psicólogos e disseram que era normal, que diminuiria com a idade". Como nos lembra Foucault (1988) as identidades individuas e sociais, a partir do século XVIII se vinculavam cada vez mais a identidade sexual. A verdade dos sujeitos estava na busca interior sobre os desejos, os prazeres, as práticas, enfim, sobre as questões que foram se tornando "sexualidade", identidade sexual que começava a ser cobrada de todos, instauradas nos corpos e nas subjetividades. As homossexualidades 
inventadas no século XIX (FOUCAULT, I988), também passam a ser buscadas nos corpos, se tornando constituidoras dos sujeitos, absolutizando as identidades homossexuais, de forma que o homossexual se torna o que faz, o que deseja, o que sente. A narrativa e escrita de si que constrói TaradaoZS está neste jogo instituído no século XVIII/XIX, de forma que ele se torna o outro absoluto.

Mas a narrativa também parece incorporar outro aspecto de construção das homossexualidades advindo do século XIX e que se faz presente até hoje. As homossexualidades surgem de um julgamento. Resultado do discurso médico elas surgem como doença, como algo que deveria ser tratado, curado, expulso das pessoas. Desta forma, deve ser ocultado. Ao esconder o rosto, Taradao $Z S$ se relaciona com essa necessidade de ocultar. No entanto, ao criar um blog em que revela suas práticas, seu corpo, suas relações, ele também dialoga com o ocultamento, pela relação entre esconder e mostrar. Porque a necessidade de criar um blog? Até que ponto a página ajuda e se relaciona com o ocultamento dos seguidores? "Filmo minas fodas por vaidade sim, confesso que me gabo quando acesso minba caixa de e-mails e recebo incontáveis propostas pra filmar, comentários nos vídeos, mensagens, algumas de pessoas desaforadas que não têm a coragem de mostrar a cara, mas sei quem são e desejo muito que elas continuem falando mal e perdendo o tempo delas me julgando". Narrar-se, ocultar-se, mostrar o corpo e não o rosto, visitar a página, ver os vídeos, escrever comentários e não revelar-se são jogos estabelecidos a partir do blog, a partir da construção desta personagem TaradaoZS, da sua narrativa e a partir da relação entre público e privado. A personagem TaradaoZS viola essa separação, trazendo para o espaço público, para internet, coisas da intimidade, que "deveriam" ficar ocultas.

Ao escrever sobre seus desejos, suas práticas, suas procuras, ou seja, ao narrar-se, Taradao $Z S$ vai se formando como sujeito ético e estético, como ficção e construção, como um ser pode assumir muitas formas e que exercita toda sua versatilidade.

[... nunca mostro meu rosto e das pessoas que aparecem nos meus vídeos, para que tudo fique na sua imaginação. Assim você pode construir a 
sua realidade e fugir para lá, esquecer do mundo, da chateação e dos problemas. [...] Sou o rabudo que é arregaçado por qualquer dotadão sem compromisso, sem pudor, sem importar em saber o nome, sem culpa. Para os ativos, sou o pirocudo arregacador, que pega um passivo pela cintura, mete na pressão...

O blog se constitui como espaço de vida, guia de conduta -TaradaoZS também estabelece o que pode e o que não pode nas suas relações, o que é certo e o que é errado. Para a composição deste artefato cultural, é organizado texto, vídeos, contos, mensagens, comentários, propostas, tabelas de acesso, outros exemplos de blogs e práticas semelhantes, enfim, fragmentos que dão origens a vidas distintas, mais libertárias e como material de memória. TaradaoZS na sua busca por novas experiências sexuais, constrói enredos e estratégias, tais como os contos em que fica no ar, trata-se de ficção ou de casos verídicos, imagens, enfim, mecanismos para criar e divulgar sua intenção, suas práticas, sua constituição, envolvendo com o mundo de uma forma diferente de outros homossexuais de forma que cria uma vida toda sua. Uma vida própria que não está fora do social, do contexto em que é produzida, já que não ter rosto e manter-se no anonimato é dialogar com a sociedade atual. $\mathrm{O}$ anonimato é parte desta sociedade que está vivendo a passagem da disciplina para o controle. Algo que aproxima o que TaradaoZS faz com uma arte de vida não fascista. (RAGO; VEIGA-NETO, 2009) A arte da vida não fascista se constitui como um tipo singular de prática de si.

\section{Novas homossexualidades?}

“Novas homossexualidades?” Mais que um título, uma questão, uma pergunta que tem como objetivo instaurar a dúvida no leitor, trazendo-o para o diálogo com o texto, mas que também tem a função de socializar o que acho importante a partir da organização de TaradaoZS, ou dos processos que constituíram as condições de emergência de um blog como esse e o que faz conosco. Essa questão só é possível porque diz de uma concepção de 
homossexualidades que marca este texto. Homossexualidades dizem de um processo de construção, não é algo dado, natural, vinculado à essência dos sujeitos. É resultado de construção histórica, cultural, social. Não é por acaso que Foucault (I988) vai assumir que as homossexualidades foram uma invenção do século XIX, uma invenção de discursos, sobretudo o médico, que naquele momento definiu e "criou" o "homossexualismo" e o homossexual como doença e como doente, respectivamente. Ainda somos herdeiros desta origem classificatória e deste discurso médico que nos assombra. O histórico é mais forte do que podemos imaginar. Nesse sentido, TaradaoZS também parece afetado por ele. Mesmo se constituindo neste aspecto de construção ele se preocupa com os discursos que incorpora que o levam a pensar e a classificar suas práticas "inovadoras" como algo "anormal" e, portanto, próximo à doença. Diz ele: "Sempre fui muito fogoso e já procurei a ajuda de um Psicólogo e disseram que é normal e que diminuiria com a idade". A ideia do que é "normal" e do que é "anormal" insiste em aparecer, nos vinculando diretamente a um tempo e espaço historicamente marcados. Em todo momento do texto de apresentação de TaradaoZS ele parece querer se justificar, convencer os leitores que é uma "pessoa comum" como qualquer outra. Trata-se então de uma nova homossexualidade? Ou ele está tão preso ao século XIX que nada mais é do que a "mesma" homossexualidade?

Questões que nos fazem colocar sob suspeita nossa cultura. Como as palavras, ideias e ações nos educam e como educamos com elas. Pensar que as homossexualidades são construções históricas e culturais significa dizer que elas não estão presas na sua origem, mas que estão constantemente em construção, em negociação, em confronto, de maneira que não parece possível pensar que estamos falando das mesmas homossexualidades que aquelas inventadas três séculos atrás. Criar um $b \log$, inventar um personagem - TaradaoZS - assumir posturas próprias diante da sexualidade, do sexo, da relação com outro são movimentos que dizem de uma inventividade que nos possibilita pensar em novas estéticas da existência em meio a uma cultura do século XXI. Para Certeau (I995) toda atividade 
humana pode ser considerada cultural. No entanto, para que possa ser entendida como tal, é necessário que as práticas sociais produzidas tenham significado para aqueles que as realizam e para os que estão em relação com essas práticas. Esse é um aspecto que parece organizar toda produção de TaradaoZS, tanto no que se refere ao seu movimento de criação de um artefato como o blog e suas funções, quanto ao movimento que é capaz de estabelecer nos seguidores, sejam aqueles que se excitam somente em acompanhar, sejam aquele que se colocam como potenciais parceiros e mesmo os que se sentem excluídos pelas condições definidas por seu autor.

TaradaoZS é todo um trabalho de subjetivação. Ao produzir o blog, o autor se propõe a construir uma racionalidade sobre sua sexualidade e sobre as homossexualidades. Ele constrói, assim, uma nova homossexualidade para si e para os outros. Assim sendo, este espaço virtual de trocas, de conhecimento, de constituição de sujeitos é um trabalho de si para consigo. (FOUCAULT, 20Io) Por um lado o trabalho do autor para consigo mesmo na criação de TaradaoZS. Ele deixa de ser apenas o autor para se tornar o personagem, outro sujeito e um só, ao mesmo tempo. Processo e de ser o "outro" e "o mesmo" que exige racionalizar suas ações, pensar a si mesmo o tempo todo, exercer um trabalho sobre si mesmo. Por outro lado, é um trabalho de si para consigo que está presente no "outro" que acessa e participa do blog. Aqueles que acessam também são chamados a realizar um trabalho de si para consigo na medida em que o artefato designa diferentes posições de sujeito. Há a possibilidade de estar dentro das condições estabelecidas pelo autor e se propor a avaliação do mesmo para fazer parte como parceiro. Há a possibilidade de ter as condições e não querer ser parceiro, ou mesmo ser excluído na avaliação do autor. Há a exclusão via condições e estar sujeito somente a fazer parte como seguidor. Existem os encontros com os nossos sistemas de significação e julgamento de forma que podemos atacar, desvalorizar, falar mal do artefato virtual e seu autor, como também podemos valorizar, querer ver, seguir, enfim, diferentes posições diante da homossexualidade virtual que 
faz com que possamos pensar a nós mesmos, como nos tornamos o que somos? Porque penso isso e não aquilo? Como me comporto diante do que vejo? Processos que nos convidam a fazer uma elaboração de si para consigo mesmo, que nos conduz a um trabalho ou a pensar os processos que nos constituíram, os processos de subjetivação. Processos que nos conduzem a novas possibilidades de ser e pensar, investindo em novas homossexualidades, fortalecendo seu aspecto de construção discursiva, cultural, sempre abertas.

\section{Considerações finais}

O primeiro ponto que importante destacar na análise deste movimento posto em circulação com o blog TaradaoZS, ou do que ele é parte e resultado, diz de um certo enfraquecimento, cada vez maior, da totalidade. Há uma diversidade de possibilidades de se vincular as homossexualidades, com histórias que se aproximam e se distanciam, com práticas e comportamentos variados e que o blog TaradaoZS faz parte. No entanto, permanece presente uma tentativa de forjar uma identidade única - a identidade homossexual - embora seja cada vez maior o reconhecimento e aceitação da existência real da multiplicidade dos homossexuais. O blog TaradaoZS revela um jogo entre aprisionamento realizado pelas identidades e a liberdade das práticas. De certa forma demonstram a força da ideia iluminista, que organizou a racionalidade moderna e que permanece, sobretudo quando se trata da construção da identidade como uma construção idealista. Constata-se uma ideia unificadora e totalitária que o pensamento pós-moderno vem enfraquecendo sobremaneira, abandonando-a. Nosso tempo vem se caracterizando como complexo e multiforme, que resiste às reduções e simplicidades, o que de certa forma, inviabiliza o uso e a construção da "natureza homossexual", do "movimento homossexual" e mesmo a utilização de termos como "todos nós", "todos somos assim", "nós queremos isso", "nós temos que”, enfim, construções de uma totalidade que não existe, a não ser como somatório de pequenas partículas que 
muitas vezes sequer dialogam.

A necessidade de abandonar os conceitos estáveis e seguros, como, por exemplo, a ideia de identidade e de homossexualidade, como unificadora, é uma forma de pensar os discursos como algo também instável e diverso, que causa desestabilização e insegurança. Por isso, muito mais produtivo é questionar como as coisas funcionam e acontecem, compartilhando essas questões e dúvidas, ao invés de buscar saídas e respostas estáveis e seguras. Os lugares de onde as pessoas falam, os espaços em que se constroem, trocam, relacionam-se e evitam-se são múltiplos, mostrando seu caráter contingente, histórico e de construção.

A grande pergunta desse trabalho é a respeito das condições de possibilidade da existência das homossexualidades e dos homossexuais e também das condições de sua própria racionalidade, sem a preocupação de fornecer respostas, mas de socializar as problematizações. Aqui também há uma aproximação com a perspectiva foucaultiana, sobretudo a crítica genealógica, que não se limita apenas em pensar a forma como as pessoas se constroem ou são construídas, mas a partir daí pensar a possibilidade de não ser mais, de não fazer mais ou de não pensar mais como fazia e como era ou como pensava. As práticas discursivas estão sempre ancoradas em suportes provisórios, mutáveis, visto que elas são amarradas na própria história, que é contingente. Por isso, não existe resposta definitiva e acabada e pensa-se mesmo não ser produtivo e não interessar forçar respostas. A ideia é estimular uma atitude de permanente reflexão. A liberdade é essa possibilidade contínua de reflexão como caminho para a crítica e para a mudança. Devido a esses fatores, faz-se necessário analisar as condições de experiência real e não as possíveis, ou seja, as condições de construção e não suas possibilidades, o que faz dos homossexuais, homossexuais. Essas questões reforçam a ideia de que os homossexuais são construídos a partir dessas práticas discursivas, que definem as verdades, os modos de ser, de se ver, de se pensar e são os grupos gays que ajudam em sua construção. 


\section{Referências}

CERTEAU, M. de. A cultura no plural. Campinas, SP: Papirus, 1995.

FERRARI, A. “Quem sou eu? Que lugar ocupo?”- Grupos Gays, Educação e a construção do Sujeito Homossexual. Tese de Doutorado, Faculdade de Educação UNICAMP, 2005.

FOUCAULT, M. História da sexualidade 3: o cuidado de si. Rio de Janeiro: Edições Graal, 1985 .

FOUCAULT, M. História da sexualidade 2: o uso dos prazeres. Rio de Janeiro: Edições Graal, 1984 .

FOUCAULT, M. História da Sexualidade I: a vontade de saber. Rio de Janeiro: Edições Graal, 1988.

FRY. P.; MAcRAE, E. O que ébomossexualidade. São Paulo: Brasiliense, 1985.

MARSHALL, J. D. Michel Foucault: pesquisa educacional como problematização. In: PETERS, M. A.; BESLEY, T. (Org.). Por que Foucault?: novas diretrizes para a pesquisa educacional. Porto Alegre: Artmed, 2008, p. 25-39.

RAGO, M.; VEIGA-NETO, A. (Org.). Para uma vida não fascista. Belo Horizonte: Autêntica Editora, 2009. 


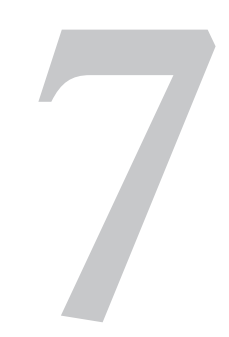

\title{
"Eu me sentia assim, meio que excluído": performances hegemônicas e as dissidências na escola ${ }^{\mathrm{I}}$
}

\author{
藻 \\ Marcio Caetano \\ Paulo Melgaço da Silva Funior \\ Treyce Ellen Silva Goulart
}

\section{Introdução}

Com os modos que configuram a educação sexual na escola e por meio de pesquisa-ação, este texto objetiva debater as performances assumidas pelas masculinidades

${ }^{1} \mathrm{O}$ artigo em tela analisa dados produzidos a partir de pesquisas financiadas pelo Conselho Nacional de Desenvolvimento Científico e Tecnológico (CNPq). Parte dos dados debatidos neste texto estão também presentes no texto "Masculinidades hegemônicas e dissidências: tensões curriculares em cotidianos de escolas da periferia" publicado na Revista Reflexão e Ação, Santa Cruz do Sul, v. 24, n. 1, p. 214-232, jan./abr. 2016. 
e como elas interagem com as identidades sexuais dissidentes, a exemplo de lésbicas, gays, travestis, transexuais e heterodissidentes. Os dados que subsidiaram a análise foram produzidos a partir das ações promovidas pelos autores deste artigo em escolas públicas localizadas na periferia de Belford-Roxo e Duque de Caxias, municípios da Baixada Fluminense, situados na periferia da região metropolitana da cidade do Rio de Janeiro.

Neste artigo, as escolas (Nós do Morro e Vozes) e suas personagens serão ficticiamente referenciadas. Entretanto, ainda que tenhamos o termo de consentimento livre e esclarecido dos indivíduos dos(as) entrevistados(as), em virtude de que os autores atuam ou atuaram nas escolas pesquisadas e que as experiências narradas são identificáveis, optamos por não situar o pertencimento de cada personagem a uma escola ou outra.

Ao considerarmos a interação entre os/a autores/a deste artigo e as escolas investigadas, optamos pela pesquisa-ação, uma vez que a metodologia proporciona aos indivíduos envolvidos na pesquisa um "caminhar junto quando se pretende a transformação da prática”. (FRANCO, p. 495, 2005) A opção pela pesquisa-ação deu-se pelo critério de permitir aos(às) envolvidos(as) participarem da situação social concreta e, mais do que isso, inspirar, por meio da problematização de ideias iniciais, o debate durante o processo e sob a influência da pesquisa.

A pesquisa-ação tem sido um método participativo desde sua origem. Com uma perspectiva prática, essa metodologia funciona melhor com cooperação e colaboração entre os sujeitos da investigação porque, conforme destaca Franco (2005), os efeitos da prática de um sujeito jamais se limitam a ele. Para a produção dos dados, foram utilizadas três abordagens metodológicas, quais sejam: (a) interação participativa nos cotidianos escolares nos anos de 20I3 e 20I4; (b) anotações de conversas informais consideradas significantes nos contextos das escolas e (c) entrevistas com os indivíduos. O artigo está estruturado em três seções: na primeira, propomo-nos a debater algumas das produções acadêmicas acerca da temática "sexualidades", buscando, com isso, aproximá-las da escola para, na 
segunda seção, proceder à análise da pesquisa. Na terceira seção, apresentamos as conclusões.

\section{Aspectos teórico-metodológicos}

Dadas as interações sociais, possuímos - em qualquer que seja o espaço em que vivemos ou atuamos - visões sobre o que seja mulher ou homem. Esses parâmetros, muitas vezes binários, são resultados dos instrumentos que nos educaram e que nos auxiliaram nas construções singulares das performances de masculinidades e feminilidades que devem produzir os indivíduos. (CAETANO, 2016)

Hegemonicamente, o sexo vem sendo entendido pelo discurso biológico como o conjunto de características genéticas, anatômicas e hormonais que distinguem os indivíduos heterodesignados ${ }^{2}$ como machos ou fêmeas. Entretanto, essa mesma palavra também é correntemente usada para designar o órgão anatômico sexual e a relação genital entre pessoas. Contudo, neste artigo, com o auxílio de Butler (2003), entenderemos sexo como um feito social marcado pelo significado cultural e não simplesmente um ato natural, uma anatomia corporal ou uma função biológica de caráter reprodutivo entendido e massificado hegemonicamente pelas ciências médico-biológicas. Assim sendo, suas redes de significados serão as mesmas daquelas que se convencionou dar à categoria "gênero".

A compreensão assumida, como sublinhado por Butler (2003), é reforçada quando consideramos a análise feita por Foucault (I988), ao destacar o caráter normativo do sexo. Para ele, assim como para ela, o sexo é um "ideal regulatório" que não só funciona como norma, mas é parte de uma prática reguladora que produz o que governa: o corpo. Ele se caracteriza enquanto um ato cuja força se manifesta como uma espécie de poder produtivo que atravessa a subjetividade dos indivíduos e se materializa nos

\footnotetext{
2 Retomamos à categoria heterodesignação hegemônica (heterodesignación hegemónica) elaborada por Magna Rodríguez (1994, p. 220, tradução nossa) que a descreverá como a "definição do outro por parte de quem tem o poder da palavra".
} 
seus comportamentos e entendimentos de si. O sexo tem o poder de produzir os contornos, os limites e as diferenças nos corpos que controla. Em outras palavras, ele é um processo mediante o qual as normas reguladoras e educativas materializam no corpo as legibilidades socioculturais do sexo e ele, por sua vez, desenvolve sua materialidade em virtude da reiteração forçada de uma norma dicotômica sexual (homem X mulher).

Com a modernidade, o entendimento sobre o sexo foi capilarizado e se tatuou no corpo. Sua lógica foi ancorada na linguagem, ganhando, com ela, significados fundamentais. Assim sendo, escrever sobre sexo, independentemente da atribuição (natural e/ou cultural), é produzir discursos sobre o controle e suas práticas pedagógicas. Nessa perspectiva, o sexo não é apenas uma dimensão pessoal do indivíduo, mas sim uma questão sociopolítica que está relacionada à forma como as sociedades organizam culturalmente os indivíduos e os localizam nos jogos identitários.

Se concordarmos com Foucault (1979), as identidades sexuais estão diretamente atreladas aos jogos de poder. Partindo desse pressuposto de que o "eu" é construído a partir e com o "outro", de forma mediada por uma relação social e de poder, o indivíduo que possui legitimidade e reconhecimento é quem está em posição de definir e atribuir papéis. Ou seja, "o exercício do poder cria perpetuamente o saber e, inversamente, o saber acarreta efeitos de poder”. (FOUCAULT, I999 p. I42) Nesse quadro, projetam-se, de forma ideológica, as performances heterossexual, lésbica, gay, trans (travesti e transexual), para citar apenas algumas.

Embora o conceito de performance seja muito amplo, no geral, ele está relacionado a eventos, espetáculos, ensaios, assim como também ao ato de dizer algo com convicção. Na performance, o indivíduo passa a acreditar no que está dizendo ou fazendo para convencer a audiência. (GOFFMAN, 1985) Pennycook (2007) reivindica o conceito para explicar as identidades. Segundo o autor, elas são produzidas através da performance repetida de gestos, falas etc., que reforçam a ideia de que existe uma essência e/ou um modo pré-estabelecido de "ser". Esses argumentos são reiterados de alguma forma na categoria "performatividade" debatida, a partir do linguista 
John Langshaw Austin, por Butler (2003). Para a estadunidense, a identidade é um ato performativo em que o discurso tem o efeito de materializar e de criar nos corpos a inteligibilidade social. Assim, ambos argumentam que não existe um "ser" anterior às marcas da linguagem em nossas subjetividades.

Nessas dinâmicas, por meio da linguagem e dos símbolos, o poder se consolida e se perpetua, porque ele cria o conceito de verdade, naturalizando determinadas situações ou questões e repugnando outras, passando, dessa forma, a produzir sentidos e significados sociais, criando o que é denominado "senso comum". Segundo Lopes (2002), uma sociedade normalizadora é o efeito histórico de uma tecnologia de poder centrada na vida. Essas normas ou códigos são aplicados de forma sutil, de modo que tornam aceitável um poder essencialmente normatizador. Ressaltamos que, através da ideologia e da hegemonia, se disseminam os discursos que determinam o que é normal/anormal, certo/errado, saudável/doentio.

Nessa direção, Caetano (2005) observa que os grupos que ocupam posições sociais de normalidade têm a possibilidade não apenas de se autorrepresentarem, como também de elaborarem e nomearem a representação de outros. Se concordamos com a afirmação do autor, as representações (que sempre produzem efeitos políticos) de "anormalidade" e "doença" nascem do ponto de vista daquele(a) que, ocupando a posição de normalidade, define, através de suas instituições, a exemplo da ciência, o comportamento padrão. $\mathrm{O}$ indivíduo que pertence a um grupo subalternizado - neste cenário, lésbicas, gays, bissexuais, travestis, transexuais e heterodissidentes - carrega a carga e o peso de sua representação.

A situação descrita até aqui nos lembra Costa (1994. p. I79), quando o autor nos descreve que a "homogeneidade supostamente atribuída à 'homossexualidade' [e, complementaríamos, à heterossexualidade] só existe quando lidamos com a figura imaginária da identidade tal como existe na abstração criada pelo preconceito". A situação produtiva em torno das identidades impulsionou a criação de grupos e o debate aberto sobre seus modelos e estratégias de disputa política nos princípios que ancoram a cidadania 
ocidental. Por meio dos discursos ideológicos amplamente difundidos pela ciência, pelas religiões, pelos movimentos sociais identitários, os homossexuais e trans, de variadas formas, buscaram acentuar positivamente o que “o estigma tinha desvalorizado" (COSTA, I994) ou redimensionaram os estigmas, fazendo deles suas dimensões políticas. $\mathrm{O}$ quadro se intensifica quando essas identidades e formas políticas são atravessadas por outras identidades, a exemplo de classe, raça/etnia e gênero. (CAETANO, 20ı6)

A forma como se configuram as identidades homossexuais e trans nos descreve, por um lado, o seu quadro produtivo, sugerindo-nos que a ciência tem o poder de criar e tornar senso comum algumas nomeações; por outro lado, evidencia-nos um esforço ativista dos movimentos sociais, sobretudo, de contrariar a heterodesignação a que suas identidades foram e são sujeitas com as narrativas científicas, jurídicas, religiosas etc. Essa necessidade ilimitada de nomeação vivenciada pelos indivíduos se inscreve em resposta aos limites impostos pela modernidade às sexualidades e ao empobrecimento da heterossexualidade como status de referência. A afirmação de Trevisan (I998, p. 200) reverbera tal concepção, quando o autor diz que:

$[. .$.$] a polivalência humana acabou sendo comprimida em catego-$
rias compartimentais como hetero, homo e bissexualidade, a partir
de definições dualísticas que se baseiam no certo e errado, natural
e antinatural, etc. Ora, tais categorias seriam dispensáveis se o ma-
cho hegemônico não precisasse se defender tanto de si mesmo [...]
a sexualidade humana floresce como uma vivência policrômica, sem
necessidade de categorias escritas, nem muito menos juízos morais
daí derivados, valendo apenas os limites do convívio social.

Esse emaranhado de formas influencia nos modos como nos percebemos, nos articulamos e nos narramos em nossas redes de sociabilidades. Com infinitas possibilidades e estilos de vida, o lócus heterossexual, por sua fragilidade, se constituiu em um corpo tornado discursivamente rígido e que, a qualquer movimento fora de suas expectativas, é localizado no marco da dúvida. Nesse sentido, Mafessoli (2007, p. 7) nos diz que: 
[...] a homossexualidade constitui, mais profundamente, uma declaração de guerra ao esquema substancialista que marcou o Ocidente: o Ser, Deus, o Estado, as Instituições, o Indivíduo - poderíamos prosseguir à vontade, com uma lista de substâncias servindo de fundamento a todas as análises dominantes. Que queiramos ou não, que sejamos ou não conscientes, a ontologia é o ponto de partida dessas análises. Em resumo, só o que é duradouro, estável, consistente, merece atenção. O individuo é seu último avatar. Ele é o Deus-Pai moderno, e a identidade, seu modo de expressão.

O quadro inspirado no diálogo com Mafessoli coabita com os marcadores que historicamente associaram a homossexualidade à frustração de expectativas de gênero, ao pecado ou à nomeação de doença. Essas três cargas atravessaram o imaginário social e quase que exclusivamente formaram e formam as imagens e as linguagens corporais das identidades sexuais marginais, associadas às identidades homossexuais, trans ou heterodissidentes, durante a maior parte do século XIX e XX. Ainda que estejamos em um momento histórico em que as identidades sexuais se configuram cada vez mais polimórficas e rizomáticas, os discursos sobre elas, todavia, permanecem mediados pela ciência hegemônica na qual a escola se baseia, como dimensão pedagógica e universalista de seus princípios, reconhecendo a autoridade do conhecimento a se configurar em seus currículos.

Estamos cientes de que não existe consenso sobre o que é currículo. Moreira (1997) assinala que o conceito está relacionado a uma complexidade de problemas e a uma determinada construção cultural, histórica e social. Porém, conforme ressalta o autor, as definições de currículo, geralmente, são desenhadas a partir de noções de conhecimento escolar e de experiência de aprendizagem. No interior do enfoque de conhecimento escolar, que tem predominado ao longo dos tempos, o currículo é o conhecimento tratado pedagógica e didaticamente pela escola e que deve ser aprendido e aplicado pelo(a) discente. É nesse caminho que surgem questões sobre o que o currículo deve eleger e como ele deve estruturar 
os conteúdos. Já no enfoque de experiência de aprendizagem, currículo passa a significar o conjunto de experiências a serem vividas pelo(a) estudante sob a orientação da escola. Entendendo que o corpo é o lócus de produção e expressão da cultura no qual a sexualidade é significada, os currículos ganham importância por serem um dos dispositivos pelos quais a escola executa a formação de seus sujeitos.

Debater currículo é direcionar ao centro de nossas questões as intencionalidades e os princípios referenciais que orientam a escola, já que, de acordo com Arroyo (20II), a escola e os conhecimentos curriculares estão no meio das disputas políticas que ocorrem em torno das identidades. Nesse sentido, a ideia de conhecimento nos currículos como um artefato relativamente neutro, tornando-o apenas um processo psicológico que se estabelece através da cognição, tem permitido uma falaciosa e letal despolitização quase integral da cultura eurocentrada, branca, judaico-cristã e heterossexual que as escolas universalizam. Aos currículos e aos seus conhecimentos universalizados deveríamos perguntar: a quem pertence a cultura que majoritariamente elabora os currículos? A que grupo social referenciam os saberes difundidos com a escola?

Os currículos escolares constituem os conflitos e os jogos de interesses de múltiplos grupos. Essa dinâmica cotidiana, sob vários aspectos naturalizada, nos leva a pensar que não se trata apenas de criticar os conteúdos e a forma como os saberes estão presentes nos materiais didáticos, nas orientações governamentais e nas avaliações escolares. Segundo Caetano (20I6), um coletivo de sujeitos pode, no mesmo tempo e espaço, mesmo que de forma provisória, subalternizar e ser subalternizado. Isso porque essas dinâmicas não acontecem em um vazio cultural, político, ideológico, econômico, religioso e se inter-relacionam diretamente com as dinâmicas de gênero, raça, classe e identidade sexual. Daí a necessidade de problematizar cotidianamente os conhecimentos universalizados pelos currículos que, mesmo quando coletivamente construídos, refletem os jogos de poder das/nas escolas. 
Como demarca Silva (1999), nas teorias do currículo, a pergunta "o quê?” nunca está separada de outra indagação: “o que os e as estudantes devem ser?”, ou melhor, “o que devem se tornar?”. Sob a lógica racional de organização dos conteúdos e das práticas intencionais da escola, o currículo busca precisamente modificar ou formar os sujeitos para a vida ocupacional adulta. De forma mais ampla, o conjunto de teorias do currículo deduzem o tipo de conhecimento importante a partir de descrições sobre o tipo de indivíduo que elas consideram ideal para constituir a sociedade e garantir o seu planejamento e os princípios de cidadania. Nesses jogos de poder originam-se os silêncios em torno das identidades sexuais dissidentes, a exemplo das LGBT, e se aprofundam, quando os cruzamos com as dimensões de gênero, raça/etnia e classe. Como Careaga afirma,

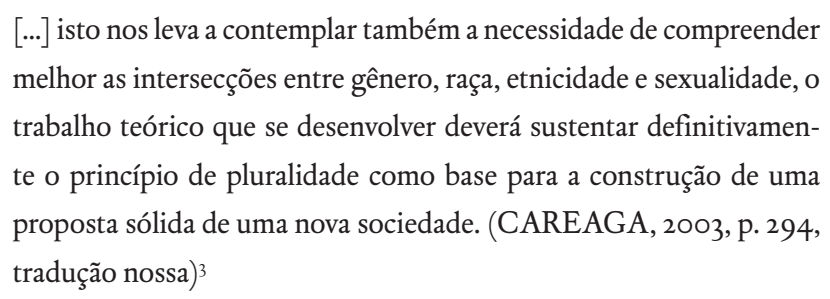

A consideração dos conceitos levantados por Careaga se insere em um momento de alterações substanciais nas ciências que, por sua vez, não estão ausentes dos debates políticos que envolvem o contexto de movimentos sociais emergentes. Ao ponderar o gênero, as identidades sexuais, a raça/etnia e a classe como questões a interrogar, em vez de fatores, por si, explicativos, esses conceitos correspondem, no plano prático-teórico -prático, ao propósito de alocar a questão das diferenças no interior da agenda das investigações acadêmicas e da elaboração de marcadores para as políticas públicas.

3 Esto lleva a plantearnos también la necesidad para comprender mejor las intersecciones entre género, raza, etnicidad y sexualidad, el trabajo teórico que se habrá de desarrollar deberá sustentar definitivamente el principio de pluralidad como base para la construcción de una propuesta sólida de una nueva sociedad. 
Assim, no leque de teorias apresentadas, as perguntas sobre o tipo de ser humano desejável para um determinado tipo de sociedade são oportunas para pensar em que posições nos currículos estão os saberes e as narrativas daqueles e daquelas que subvertem as performances e/ou posições hegemônicas sexuais, raciais e de classe. Ao questionar o tipo de indivíduo que deve comportar a sociedade, Silva (1999, p. 15) pergunta:

Será a pessoa racional e ilustrada do ideal iluminista de educação? Será a pessoa otimizadora e competitiva dos atuais modelos neoliberais de educação? Será a pessoa ajustada aos ideais de cidadania do moderno estado-nação? Será a pessoa desconfiada e crítica dos arranjos sociais existentes preconizada nas teorias educacionais críticas?

Cada pergunta leva, em si, para uma determinada "performance" de indivíduo e corresponde a determinados tipos de saber presentes na organização didático-curricular. Ao entrever a lógica que operou a elaboração das perguntas feitas por Silva (1999), outras perguntas emergem: quais as táticas criadas pelos indivíduos para subverter as lógicas normatizadoras nas escolas? Sobre quais modelos de mulheres e homens, presentes nas várias teorias pedagógicas, os indivíduos, na escola, criam suas subversões? Como os currículos se rearranjam frente às táticas criadas pelos indivíduos na escola? Como as dissidências, a exemplo das homossexualidades e heterodissidências, interpelam os currículos?

Se nos orientamos pela noção de construção social, as performances trans, gays, lésbicas e heterodissidentes estão diretamente relacionadas às maneiras pelas quais o indivíduo se relaciona com o outro e com as práticas nas quais se envolve. São constituídas nos contextos em que estão inseridas a partir dos quais os significados serão dados e entendidos. (PENNYCOOK, 2007) Nesse sentido, as considerações de Britzman (1996) podem ser úteis. A autora assinala que toda identidade sexual é um construto instável, mutável e volátil, uma relação social contraditória e não finalizada, sendo constantemente rearranjada, desestabilizada e desfeita pelas complexidades das experiências vividas, ou seja, são perfor- 
mances assumidas pelos indivíduos. Bauman (2005, p. 9I) contribui com esse pensamento sugerindo que "assumimos uma identidade num momento, mas muitas outras, ainda não testadas, estão na esquina esperando que você as escolha”. Fato que destaca o caráter transitório e múltiplo das identidades, quando o autor afirma que

O equipamento sexual de seu corpo é exatamente um desses recursos

à disposição que, como todos os outros, pode ser usado para todo tipo de propósito e colocado a serviço de uma ampla gama de objetivos. O objetivo que parece é esticar ao máximo o potencial de geração de prazer desse "equipamento natural" - testando, uma por uma, todas as formas conhecidas de "identidade sexual" e talvez inventando outras mais no caminho. (BAUMAN, 2005, p. 92)

Pensar em performances identitárias significa abrir um leque de maneiras segundo as quais as pessoas vivem e se apresentam socialmente. Essa expressão, identidade (sexual), só terá sentido se for vista como polimorfa, fragmentada, fluida, múltipla, contraditória, em constantes modificações e negociações, capaz de rearticular desejos e prazeres. Essa assertiva não pode ser tida como uma tarefa fácil. Sobre isso Britzman (1996, p. 74) afirma que

[...] nenhuma identidade sexual - mesmo a mais normativa - é automática, autêntica, facilmente assumida; nenhuma identidade sexual existe sem negociação ou construção. Não existe, de um lado, uma identidade heterossexual lá fora, pronta, acabada, esperando ser assumida e, de outro, uma identidade homossexual instável, que deve se virar sozinha.

Portanto, a construção das performances identitárias solicita um projeto pedagógico-curricular que se encarregue de "moldar" os indivíduos para que eles se enquadrem às regras legitimadas pala sociedade, tornando-os, assim, legíveis. Arriscamos afirmar, com as narrativas de nossas personagens que passaremos a apresentar, que diversas escolas estão empenhadas 
em construir e em moldar as sexualidades de seus/suas estudantes de acordo com o modelo padrão (heterossexual).

\section{Experiências e saberes com a escola: tensões e aprendizagens cotidianas}

A adolescência se caracteriza como um período de desenvolvimento marcado por intensas transformações biopsicossociais impulsionadas pelas experiências culturais e pelas mudanças hormonais da puberdade. Ainda que sobre o tema resida um complexo emaranhado discursivo, a adolescência constitui-se, no geral, como uma fase de transição entre os anos da vida infantil e a adulta. Nesse período, observam-se acentuado desenvolvimento corporal, vivências emocionais, construções de redes interpessoais de amizades etc., que interpelam a identidade, assumindo performances e mediando a construção de redes de sociabilidades (SCHOEN-FERREI$\mathrm{RA}, 20 \mathrm{IO})$. Dentre as inúmeras modificações vivenciadas na adolescência, sem dúvida, uma das mais significativas está relacionada às nuances da sexualidade.

Ainda que seja indeterminado o período cronológico que irá dar conta das transformações do corpo na adolescência, no geral, elas acentuam-se entre os io e i6 anos. Porém, os limites cronológicos da adolescência são definidos pela Organização Mundial da Saúde (OMS) entre Io e I9 anos e pela Organização das Nações Unidas (ONU) entre 15 e 24 anos. No Brasil, as normas e as políticas de saúde do Ministério de Saúde estabelecem os limites da faixa etária aglutinando a adolescência e a juventude com o período que compreende as idades de io a 24 anos. Já o Estatuto da Criança e do Adolescente (ECA), Lei n. ${ }^{\circ} 8.069$ de I990, considera criança a pessoa até I2 anos de idade incompletos e define a adolescência como a faixa etária de I2 a I8 anos de idade (Art. 2) e, em casos excepcionais e quando disposto em lei, o Estatuto é aplicável até os 2r anos de idade (Art. I2I e I42). Portanto, independentemente da perspectiva, o período da adolescência é vivido, quando respeitada a legislação brasileira, na escola. 
Dada a importância dos conhecimentos universalizados pela escola, ela é corresponsabilizada pela formação do indivíduo, podendo caber-lhe a possibilidade de desenvolver com seus/suas estudantes uma educação sexual. Silva Júnior (2014) argumenta que educar sexualmente seria oferecer condições para que as pessoas assumam seus corpos e suas sexualidades distantes das dimensões do medo, preconceitos, culpas, vergonhas, bloqueios e/ou tabus que correntemente atravessam as ações educativas hegemônicas em torno da sexualidade. Sem contar que a ausência do diálogo aumenta a possibilidade dos/das adolescentes de se encontrarem com a rede de riscos relacionados ao exercício da sexualidade, a exemplo da gravidez indesejada, do contágio com as Infecções Sexualmente Transmissíveis (ISTs), de traumas psicoemocionais resultantes de experiências frustrantes, dentre outras experiências. (TRINDADE; BRUNS, I999)

Candau (2003) argumenta que a instituição escolar representa um microuniverso social que se caracteriza pela diversidade social e cultural e, por vezes, acaba reproduzindo padrões de conduta que permeiam relações sociais do contexto mais amplo. O cotidiano escolar é, assim, marcado por uma série de contradições e conflitos, em que diferentes visões de mundo, crenças, valores culturais, entre outros, se encontram.

Ainda que saibamos que, cotidianamente, disputam saberes nas escolas, as tentativas de orientá-la por uma determinada ideologia e refleti-la em suas dinâmicas didático-curriculares, fazem-nas espaços de disputas entre a perspectiva monocultural, político e curricularmente hegemônica, e as narrativas e memórias dos coletivos de indivíduos que historicamente foram subalternizados. Com Arroyo (20II), sabemos que o silenciamento das vozes destoantes do discurso central tem como objetivo a (re)produção de indivíduos com aquelas características desejáveis do ponto de vista do funcionamento social normalizado.

As narrativas que seguem são algumas cenas do cotidiano escolar vividas pelos autores que apresentaram como as performances sexuais estão sendo vivenciadas nas escolas e justificam a necessidade do trabalho de problematização das práticas curriculares: 


\section{Cena I:}

Em uma grande escola da rede pública estadual do Rio de Janeiro, dois alunos do $9^{\underline{0}}$ ano, apoiados por diversos/as colegas de turmas, se apresentam à direção reivindicando o mesmo direito dos casais heterossexuais de andar de mãos dadas e de se beijar no ambiente escolar. Apesar de a dupla ter sofrido muitas críticas negativas, principalmente dos alunos do sexo masculino, eles conseguiram provocar uma grande inquietação, incômodo e discussões no cotidiano da escola. Como resultado, a direção proibiu qualquer manifestação de namoro seja entre casais heterossexuais ou homossexuais.

\section{Cena 2:}

Em uma escola da rede municipal da cidade de Duque de Caxias-RJ, um aluno de 16 anos é posto para dormir fora de casa. Ao saber disso, a diretora procura a mãe para conversar sobre a questão. Ao voltar para a escola, a diretora diz aos/às professores/as: "A mãe é uma senhora muito trabalhadora, sustenta a família sozinha, a atitude dela foi apenas para ajudar o filho. Só está fazendo isso, para ver se o filho aprende a se tornar homem. Ele está andando com gays e ela tem medo de que ele se desvie.” Para encerrar a conversa, a diretora pergunta: "Qual mãe quer um filho gay?”

\section{Cena 3:}

Em outra escola da rede municipal da cidade de Duque de Caxias-RJ, dois alunos de 15 anos conversam com o professor sobre uma garota: "Olha, comigo é assim, professor, eu mando logo ver... eu pego direto. Olha aqui (mostrando sua cor)... sou negão, brincou, eu tô pegando.” Isso para afirmar a virilidade do homem negro.

Esses episódios ocorridos nas escolas fluminenses são acontecimentos que estão ocorrendo de diferentes maneiras em diversas escolas do país. Vários(as) estudantes estão descobrindo, inventando e/ou vivenciando 
suas experiências e, enquanto algumas formas de masculinidades e feminilidades são reconhecidas e valorizadas, aqueles(as) que se descobrem ou se reconhecem lésbicas, gays, trans ou heterodissidentes são os(as) que possuem maiores dificuldades em encontrar apoio tanto das famílias como das escolas. (CAETANO, 2005, 20II)

$\mathrm{Na}$ primeira cena narrada, a escola decide pela igualdade, ao proibir qualquer manifestação romântico-afetiva dentro da instituição. Como se, com esse ato, eximisse-se e reafirmasse o discurso de que, cabendo à escola apenas universalizar o que exige o currículo oficial, não é espaço para discussão ou experiência de nossas afetividades e sexualidades. Entretanto, ao concordarmos com Caetano (20I6), acreditamos que todos os gestos, os artefatos, as relações estabelecidas na escola educam e compõem os movimentos curriculares. Com a proibição, a escola, por um lado, educa para uma sexualidade heteronormativa e, ao mesmo tempo, torna-se mais um lugar em que a homossexualidade é reafirmada no espaço da diferença a ser rejeitada. Ao tratar a diferença de forma igual, cria determinada falsa simetria que só existe no discurso.

Essas narrativas do cotidiano parecem reforçar o que foi afirmado por Welzer-Lang (200I) sobre as relações sociais de sexo. Para o autor, tais relações foram construídas sobre um duplo paradigma naturalista. Por um lado, afirma-se uma pseudonatureza superior masculina em que homens e mulheres aparecem sempre atrelados em uma relação complementar/ dependente de dominação e, por outro, há o reforço de uma visão heterossexuada do mundo em que as outras sexualidades aparecem situadas no campo da diversidade.

É importante ressaltarmos a concepção de que a lógica binária de pensamento não começa ou termina nas relações sociais sexuais entre homens e mulheres, mas encontra-se transversalizada no conjunto da sociedade. Por essa razão, ratificamos o dito por Welzer-Lang (200I), quando esse afirma a existência de um duplo poder na estrutura funcional da masculinidade: sobre mulheres e sobre homens. Ou seja, o constructo social que concebemos como ideal, cujo centro é ocupado pelo sujeito 
universal (homem, branco, heterossexual, cristão e proprietário), tem como eixo central a dominação sobre os corpos femininos e as masculinidades subalternas, como, por exemplo, a de homens negros. Nesses termos ideais, o que as cenas escolares nos permitem apreender é que os/as dissidentes são ameaças à performance estruturada e estruturante da heteronormatividade e sobre eles/as devem ser aplicadas forças (violência) que os/as adéquem aos princípios estabelecidos pela norma social, tornando-os/as coerentes e legíveis à normalidade.

Conforme nos sugere a terceira cena, a essas relações não escapam as masculinidades subalternas. Nessa direção, se o núcleo das relações sexuais de gênero é a violência de gênero e a abjeção/dominação ao feminino enquanto afirmação da masculinidade, aos homens negros não há, discursivamente, outra alternativa para a afirmação de sua humanidade a não ser a ratificação de uma performance masculina hegemônica. Assim, a narração da fala do estudante nos supõe a tentativa de que esses corpos, ao não possuírem a possibilidade de dissimular totalmente sua negritude, pois fenotípica, se autoafirmem a partir de elementos que, dentro de relações coloniais de poder, retroalimentam os discursos que os subalternizam.

Nas interações vividas nas escolas, distintas masculinidades se entrelaçam e se atravessam. Entretanto, o discurso predominante entre os rapazes é o da masculinidade hegemônica. Devemos ressaltar que pensar em masculinidade hegemônica é pensar em uma versão de algo que foi criado, construído, imaginado, considerado como padrão e disseminado a partir do discurso e que, a cada momento, busca ser consolidado nas performances de masculinidades.

Nos corredores, no pátio e nas salas de aula, podemos perceber jovens rapazes, em sua maioria negra, com idades que variam entre io e i8 anos, desenvolvendo performances de masculinidades hegemônicas ${ }^{4}$, destacando

${ }^{4}$ O conceito de hegemonia elaborado por Antonio Gramsci, apropriado e relido por inúmeros autores e autoras, permite ver o campo social como um espaço em que grupos domi- 
sempre a presença do falo, a virilidade comprovada pela exibição afetiva de relações com as meninas e a força física demonstrada com os músculos. As brincadeiras significadas como masculinas se apresentaram em uma linha muito tênue entre a violência física e a exibição de força e coragem, fato que se encontra com a afirmativa de Connell (I995) de que o gosto pelos esportes e a representação da força são performances reivindicadas pelos homens para evidenciar socialmente suas masculinidades aproximadas aos marcadores culturais hegemônicos de seu sexo.

Nas aulas com atividades esportivas e recreativas, podemos ver diversas brincadeiras e jogos de medir força, nos quais os jovens podiam se abraçar e se tocar sem gerar suspeita e dúvida sobre suas performances masculinas. Inclusive tamanha interação constitui parte considerável do enredo masculino naquele espaço e seria impensado seu desenvolvimento com meninas. Nessas interações, percebemos que as maneiras de convivência entre os meninos destacam um interessante aspecto na amizade entre eles que, embora pareçam não valorizar uma amizade orientada pelo toque corporal ou intimidade, procuram se organizar em grupos. Entretanto, sempre parecem manter certa distância afetivo-emocional, evitando manifestações de carinho.

Os estudantes, quando em grupos, apresentavam elementos de competitividade, agressividade e violência. Esse quadro nos aproxima das afirmações feitas por Badinter (1993), a partir de suas pesquisas, de que os diversos adolescentes faziam questão de exaltar a virilidade e a força como forma de destacar a masculinidade. Tal fato reitera que masculinidades são práticas diárias nas quais os garotos se engajam e precisam a todo o momento reafirmar através da negação das marcas que tatuam os corpos femininos. (CONNELL, 2000)

nantes se veem obrigados a esforços permanentes de convencimento ideológico com o fim de manterem suas dominações. É precisamente através desses esforços de convencimentos que a dominação econômica se transforma em hegemonia cultural. (SILVA, 2007). Entretanto, isso também denuncia que, no interior da hegemonia, coexistem inúmeros outros grupos. 
Por outro lado, as práticas pedagógicas escolares reiteravam essas ações quando não problematizavam as ações que, mesmo legalmente respaldadas, infligiam a integridade do outro. Em conversa com a coordenadora de turno da Escola Nós do Morro sobre as relações entre estudantes, em um determinado momento, ela nos disse:

Tá vendo aquela ali [...] (ao se referir a uma das alunas), ela enfrenta qualquer um [...] nenbum menino brinca com ela [...] outro dia ela apareceu com o olbo roxo, disse que caiu. Mas os outros alunos falaram que ela encarou um menino aqui na rua.

Miskolci (2005, p. I4) destaca que "as preferências são construídas e a escola tende a contribuir para que elas sigam o padrão socialmente imposto do que seria certo ou errado, aceitável ou passível de rejeição”. Assim, constroem-se homens e mulheres de acordo com um padrão pré-estabelecido e rejeitam-se aqueles(as) que fogem à norma. A violência parece ser a marca que reitera e promove a legibilidade da masculinidade.

Os indivíduos entrevistados relataram como começaram a perceber as primeiras diferenças, sofrendo e tendo de enfrentar diversas dificuldades na escola, além de terem seus desejos e sentimentos ignorados pela comunidade:

Na escola, os colegas são os piores. Nas brincadeiras com os meninos, eles dizem: 'Você não sabe brincar, vai brincar com as meninas'. 'Ab! Vai brincar de boneca'. Quando o professor me chama para ir ao quadro, aí começam as brincadeiras, né! Os palavreados, aquelas coisas... Eles me abordavam muito fora da sala de aula também, em qualquer lugar, bastava eu me manifestar que aí comecava. (Pedro, 8 anos)

As escolas são, no geral, um dos mais perversos espaços para uma criança que performatiza marcadores sexuais contra hegemônicos. (BRITZMAN, I996, 200I; SULLIVAM, I996; CAETANO, 2005, 20II). Elas são cruéis não somente por nomear o indivíduo, mas por classificá-lo antes 
mesmo que ele tenha conhecimento sobre as redes de significados que se operam em sua classificação.

Nas escolas, podemos perceber uma unidade entre heterossexualidade e masculinidade formando um vínculo que, pelo senso comum, parece naturalizá-la. Com isso, ao serem negadas outras possibilidades performáticas, o trabalho de produção de identidades se torna sistemático, acentuado pela preocupação de introduzir o menino ao mundo masculino hegemônico (CONNELL, 1995), como o dos esportes, do reconhecimento e da agressividade física, ao mesmo tempo em que valoriza sua facilidade para o domínio da racionalidade, enquanto que, com a menina, busca enfatizar a delicadeza, a emoção. Moita Lopes (2002, p. 155) afirma: "os professores homens constantemente usam insultos sexuais como 'não seja mulherzinha' para garantir o desempenho da masculinidade hegemônica", reforçando, com isso, o discurso do senso comum, como nos permitem observar as seguintes narrativas:

Um professor de Matemática... me colocou em uma situação que eu não esperava, disse que só um bomem resolveria o problema ... e u errei... e ai!! Se fosse os colegas eu até esperava, a gente passa por cima... mas professor... (João, I9 anos)

Eu ia para a escola e a professora sempre me colocava ao lado dos meninos. É muito cômodo pros professores ... de um lado ou de outro, né? Então eu me sentia assim, meio que excluido ... porque eu queria ficar do lado das meninas e me colocavam do lado dos meninos, mas, como me colocavam do lado dos meninos, eu estava me sentindo... excluído... meu lugar era do lado dos meninos, mas eu não queria. (Dayse, I8 anos)

A narrativa de Dayse, que inspirou o título do artigo, e as experiências de João reforçam a ideia de que a escola, ao adotar o modelo binário e defender as expectativas sociais e sexuais naturalizadas de gênero, acaba por ocultar, silenciar e marginalizar outras possibilidades performáticas que 
vivem na excentricidade desse jogo dicotômico. Nessas relações de poder, a depreciação das performances lésbicas, gays, trans e heterodissidentes se dá, primeiramente, por meio do policiamento de gênero. A discriminação ocorre porque a escola participa da rejeição daqueles(as) que vivem masculinidades (ou feminilidades) de formas diversas das hegemônicas, o que contribui para que tais sujeitos não sejam reconhecidos como homens e mulheres de verdade (MISKOLCI, 2005), evidenciando o caráter homofóbico, lesbofóbico e transfóbico das práticas didático-curriculares da escola.

Eu já deixei de ir à escola, eu não queria frequentar a escola que eu estava. Era muito sofrimento. (Dayse, I8 anos)

Com a narrativa de Dayse, observamos que, ao ignorar as condições diárias de violências sofridas pelas populações de lésbicas, gays, trans e/ ou heterodissidentes, o sistema educacional é um dos principais responsáveis pelas práticas educativas de perpetuação da homofobia. (CAETA$\mathrm{NO}, 2 \mathrm{OI}$ )

Sullivan (1996, p. 19) argumenta que "nenhuma criança homossexual, [...], se sentirá à vontade no seu mundo sexual e emocional”, ao ser reconhecida como a diferente. Essas afirmativas são bastante relevantes, pois a partir do momento em que a escola, com seus conhecimentos universalizados, adota uma ideologia heterossexista, seja pela negação da homossexualidade ou pelo silenciamento de sua existência, reforça os discursos trazidos de casa por aquela criança que aprendeu, no seio familiar, que a homossexualidade é um "pecado", uma "anormalidade" ou um "erro". Dessa forma, esse sujeito poderá, com o aval de uma escola que se exime da discussão de gênero/sexualidade, crescer acreditando na veracidade dessa informação e, ainda, dependendo da maneira como encaminhará sua sexualidade na fase adulta, o significado dessa construção social poderá ser desastroso para si e para a sociedade. 
Inúmeros(as) autores(as) descrevem as dificuldades que docentes têm em desenvolver didática e curricularmente temas correlacionados aos eixos "gênero", "sexualidade", "homossexualidades", "transexualidades" e "travestilidades", mesmo com as formações continuadas e o crescente aumento de disciplinas ofertadas nas licenciaturas5. Esse quadro contribui com a ideia de que as discussões em torno das temáticas sexualidades e/ou gênero não se configurem nos currículos, não se encontrando entre as prioridades da escola. Essa afirmação nos revela duas situações iniciais: o desconhecimento das relações e das práticas cotidianas das escolas e o conceito enrijecido em torno das sexualidades.

Historicamente, "gênero" e/ou "sexualidade", mesmo quando não verbalizados, estiveram presentes nas formas como as escolas estabeleceram seus discursos e orientaram suas práticas pedagógicas. Poderíamos citar inúmeros casos em que trouxeram, como pano de fundo, as preocupações com a sexualidade. Entretanto, acreditamos que nenhum caso seja mais expressivo que a preocupação com a presença de mulheres e "pervertidos" nos espaços escolares.

Blazquez Graf (2008) nos retrata a dura situação enfrentada por mulheres para ascenderem a espaços representativos nas ciências. A complexa rede que desenha a situação assimétrica de mulheres na academia é auxiliada pela própria rejeição que elas sofreram na maior parte da história moderna da educação escolar e da pesquisa acadêmica. Inúmeros fatores

${ }^{5}$ Em quase 10 anos, o Ministério da Educação (MEC) vem ampliando, substancialmente, através de programas de qualificação profissional, suas ações de enfrentamento às práticas homofóbicas, sexistas e racistas na escola. Foi com a Secretaria de Educação Continuada, Alfabetização, Diversidade e Inclusão (Secadi), em parceria com as Instituições Públicas de Educação Superior, que o Ministério da Educação formou, entre 2006 e 2012, mais de 60 mil gestores(as) e profissionais da educação, com um investimento total de mais de 50 milhões de reais. Todos os dados relacionados aos investimentos do MEC foram obtidos através da apresentação "Ações desenvolvidas pelo Ministério da Educação na área de gênero e diversidade sexual/2011", realizada pela Coordenação-Geral de Direitos Humanos (CGDH) da Secadi do Ministério da Educação no I Seminário de Educação e Diversidade sexual, organizado pelo Grupo de Estudos e Pesquisas em Sexualidades da Universidade Federal do Espírito Santo, em 3 de outubro de 2011. 
justificavam esse cenário, entretanto, dois argumentos nos parecem bastante representativos desse quadro: primeiro, a presença de mulheres impossibilitaria aos homens as condições necessárias à aprendizagem, pois elas teriam a capacidade de "desconcentrá-los" e "seduzi-los"; e segundo, a escolaridade das mulheres era desnecessária frente às tarefas domésticas a elas atribuídas. Nesses casos, a sedução parece ser a palavra-tradução das preocupações escolares com as mulheres e com os "pervertidos" nas escolas. Correntemente, ela é o dispositivo que alimenta os discursos opositores aos/às professores/as ilegíveis na escola: suas tumultuadas performances de gênero e confusas sexualidades seduziriam (referencialmente) os alunos e as alunas. Esse é o medo.

A situação em que se encontra o eixo gênero-sexualidade na escola favorece os movimentos heteronormativos, as tensões curriculares e acaba por consolidar a sexualidade como uma scientia sexualis, como nos descreve Foucault (1988). Na perspectiva do autor, haveria duas formas de apropriação da sexualidade por saberes, uma, via scientia sexualis, como já dito, e outra, através da ars erotica. Enquanto que, na última, o prazer, a curiosidade e a subjetividade encontram-se na agenda de discussão e na experiência, para a anterior, a narrativa seria conduzida pela cientificidade com ênfase na preocupação com a reprodução. Cotidianamente, embora ambas estejam presentes e tensionem-se nos currículos, dada a forma moderna de organização da escola, é indiscutível que a scientia sexualis goza de maior prestígio e reconhecimento escolar. Essa situação, com auxílio Britzman (200I), nos faz recordar que, quando a sexualidade se converte em objeto do conhecimento, tendo, por sua vez, suas metáforas científicas aplicadas à população, ela gera outros movimentos de subalternidades, de desigualdades e, portanto, de controle e de fronteiras à felicidade e à satisfação.

Quando tentamos mapear a geografia do sexo [...] ou quando tentamos ler a sexualidade através de uma teoria favorita, um manual de instrução ou de acordo com as visões dos chamados especialistas. 
Quando inserida no currículo escolar ou na sala de aula universitária - quando digamos, a educação, a sociologia, a antropologia colocam sua mão na sexualidade - a linguagem do sexo torna-se uma linguagem na sexualidade - a linguagem do sexo torna-se uma linguagem didática, explicativa e, portanto, dessexuada. Mais ainda: quando o tópico do sexo é colocado no currículo, nós dificilmente podemos separar seus objetivos e fantasias das considerações históricas de ansiedades, perigos e discursos predatórios que parecem catalogar certos tipos de sexo como inteligíveis, enquanto outros tipos são relegados ao domínio do impensável e do moralmente repreensível. (BRITZMAN, 200I. p. 90)

Porém, mesmo com todo esse quadro, pensamos que seja nas possibilidades produtivas do poder e da resistência que surgem outros estilos de vida, invenções e subversões. E é sobre elas, mas sem perdermos de vista nosso cenário discursivo, ou seja, as escolas, que queremos discutir com maior ênfase neste momento.

Inúmeras pesquisas no campo da educação apontam para a ideia de que a sexualidade e o gênero se configuram na escola como "objetos" das disciplinas biológicas. Se, à primeira vista, a "biologização" dessas temáticas nos parece equivocada, temos que, dadas as forças religiosas judaicocristãs, seria este o caminho encontrado pelas(os) professoras(es), para desenvolverem, estrategicamente, as suas ações asseguradas nos Parâmetros Curriculares Nacionais (PCN).

Nessa direção, a escolha político-pedagógica de "biologizar" as discussões sobre a sexualidade não somente obedece à lógica moderna de escola e de formação dos e das professores(as). Também podemos pensá-la como uma estratégia docente frente às possíveis oposições religiosas, políticas ou familiares ao trabalho com as sexualidades. Essas resistências silenciosas estão presentes em nossa escola-cenário, conforme nos foi dito pela coordenadora da Escola Vozes no depoimento que segue:

[...] busquei justificar inúmeras vezes minhas ações de prevenção às DST, com base nos dados cientificos e "incontestáveis" dos Boletins epidemiológicos 
do Ministério da Saúde e resoluções do Ministério da Educação. Todas as possiveis reclamações ao trabalbo eram direcionadas a um ser abstrato das Secretarias ou Ministério da Educação.

Nesse caso, a cientificidade do conhecimento biológico despersonaliza a resposta informada pelo(a) docente. Sob essa perspectiva, as afirmações dadas aos alunos e às alunas não são oriundas de suas experiências, mas resultantes de dados confirmados pela ciência. Ao mesmo tempo, é importante termos a perspectiva de que a ciência, com seu discurso e sua prática, é resultante de um dado momento histórico motivado pelo interesse de setores de uma dada sociedade. Portanto, ela é reflexo da cultura e, sobretudo, das relações de poder. Assim, a reprodução de conceitos científicos, isenta de qualquer dado de problematização, auxilia a subalternidade dos alunos e das alunas e a ausência de autoridade epistemológica da professora e do professor.

Nas escolas pesquisadas, as temáticas gênero e sexualidade aparecem descritas no Projeto Político-Pedagógico (PPP). Ainda que a coordenadora pedagógica da Escola Vozes desenvolva atividades considerando especificamente as temáticas gênero e sexualidade, o PPP da escola não apresenta nominalmente os temas como relevantes aos seus currículos, ao contrário da Escola Nós do Morro cujo PPP destaca que a escola pretende "ultrapassar a visão limitada de que orientação sexual é falar de doenças e métodos contraceptivos de patologia sexual. O que se quer com este projeto é tratar das dimensões afetiva, prazerosa, ética e criativa da sexualidade humana". (VEIGA, 2004, p. 26) Nesse sentido, debater a construção do PPP é direcionar ao centro de nossas questões as intencionalidades e os princípios referenciais que orientam a escola. Essa assertiva nos encaminha a pensar nas relações entre escola, currículo, gênero, sexualidade e PPP.

Fruto das reivindicações dos movimentos sindicais de professoras(es) na elaboração da Lei de Diretrizes e Bases da Educação Nacional (LDB) Lei n. ${ }^{\circ}$ 9394/94-, o PPP se configura na legislação como um documento que deve ter seus objetivos definidos coletivamente pelos sujeitos da ação 
educativa (estudantes, profissionais da educação e responsáveis). Desse modo, o PPP existe porque se define como ação que é anteriormente pensada e idealizada pelo coletivo da escola. É aquilo que se quer em torno da perspectiva educacional: a qualidade do ensino através de sua proposta curricular. É através da existência do PPP que a escola narra e registra sua história, já que ele é reconhecido como o conjunto das diretrizes e das estratégias que expressam e orientam sua prática político-pedagógica.

Ideologicamente o PPP, de forma coletiva, vai sendo construído ao longo do percurso de cada instituição escolar. Conforme Veiga (2004), ele explicita a filosofia e as diretrizes da educação nacional com a realidade da escola, traduzindo a autonomia relativa da instituição e definindo seu compromisso com o contexto a que está inserida. Esta ideia implica a necessidade de uma relação contratual dos atores e atrizes da escola, daí a importância de que seja elaborado participativa e democraticamente.

Diferentemente de várias outras palavras que carregam uma multiplicidade de sentidos e usos, a categoria "projeto" parece se configurar com tranquilidade entre autores e autoras. Ela, no geral, tem representado a articulação entre os tempos presente e futuro, sendo a marca de passagem de um determinado presente vivido para um presente previamente elaborado no futuro. Portanto, o projeto é uma cadeia de intencionalidades utilizada para procurar solucionar problemas, construir conhecimentos e configurar situações.

Ainda, com Veiga (2004), todo projeto pressupõe ruptura com o presente e a promessa com o futuro. Projetar traduz tentar quebrar um estado confortável para aventurar-se em possibilidades previamente elaboradas. Atravessar etapas de instabilidade e buscar uma estabilidade em função das promessas de melhorias que os projetos promovem com relação ao presente. Diante do dito, como se situa o PPP com as dimensões da qualificação pedagógica? Quais são suas configurações e significados? $\mathrm{Na}$ década de I990, a ideia de projeto pedagógico tomou corpo no discurso oficial e em diversas instituições de ensino no Brasil. A LDB, em seu artigo I2, inciso I, previu que "os estabelecimentos de ensino, respeitadas 
as normas comuns e as do seu sistema de ensino, terão a incumbência de elaborar e executar sua proposta pedagógica”. Esse quadro deixou marcado o princípio de que a escola não podia prescindir da reflexão sobre sua intencionalidade educativa.

O PPP tem assumido, entre autores e autoras, basicamente duas dimensões: o pedagógico e o político. Ele é substancialmente político, já que assume o compromisso com a formação cidadã para um tipo de sociedade e é também pedagógico, porque possibilita a organização dessas intencionalidades curriculares que buscam ensinar, através da escola, para a cidadania.

Ao propagar determinadas "verdades", os currículos, orientados pelo conjunto de intencionalidades presentes nos PPPs, acabam por autorizar algumas vozes e por negar outras com suas práticas pedagógicas. Para Silva (I999, p. I2), “o currículo estabelece diferenças, constrói hierarquias e produz identidades". No que diz respeito às sexualidades, o modelo de indivíduo presente nos conhecimentos universalizados com os currículos hegemônicos ainda continua referenciado pela lógica cultural dos conhecimentos produzidos pelo homem branco, heterossexual, cristão e proprietário. Da mesma forma, a lógica aplicada no currículo supõe que o sexo biológico determina o gênero e se entende o "natural" como "normal”, como "dado" (BUTLER, 2003) e que orienta, nessa normatividade, o desejo "dado e natural”, o qual, por sua vez, deve ser voltado para o gênero, sexo e sexualidade construídos enquanto opostos. Em outras palavras, os currículos, hegemonicamente, reverberam a linearidade supostamente coerente entre sexo-gênero-desejo-orientação sexual.

\section{Considerações finais}

A proposta central deste estudo foi refletir sobre a importância de a escola estar atenta às questões de gênero e sexualidades que, constantemente, indagam as práticas curriculares. Assim, a escola pode oferecer possibilidades para a desconstrução da heterossexualidade como norma, criando 
possibilidades para que estudantes pudessem construir suas identidades sexuais de forma autônoma e que as diversas sexualidades pudessem co -habitar no contexto escolar. Nessa perspectiva, a pesquisa elucidou que existe, nas escolas pesquisadas, uma preocupação em desenvolver e trabalhar um programa que promova e incremente debates e práticas pedagógicas que interroguem a sexualidade e o gênero em suas intersecções com classe e raça.

Entretanto, nesses termos, a lógica aplicada nos currículos está centrada nas relações complementares e assimétricas entre homem e mulher (masculino e feminino), nas quais os relacionamentos aceitáveis e as famílias bem consideradas são formados com base no sexo biológico (oposto macho e fêmea) e visando à reprodução. Nessa lógica, aqueles(as) que, por alguma razão ou circunstância, escapam à norma e promovem uma descontinuidade na sequência sexo/gênero/desejo/orientação sexual, serão tomados(as) como "minoria” e serão colocados(as) à margem dos currículos. Desse modo, as demais identidades sexuais, principalmente a homossexual e trans, frequentemente são negadas pelos currículos e passam a ser vistas como "outras", como a "negação da identidade dominante", fato que contribui, em muito, para a construção de identidades vulneráveis à violência. (BRITZMAN, 1996)

Poderíamos considerar que a Escola Nós do Morro propõe uma visão ampla de se trabalhar as temáticas no contexto escolar. Entretanto, isso significaria uma tentativa de romper com as possibilidades de naturalização e de cristalização das identidades sociais, de gênero e sexuais, apresentando novas possibilidades de discussão? Os fragmentos das narrativas de seus/suas estudantes descritos neste artigo nos dão pistas dos desafios impostos para além do que deseja ou expressa a instituição escolar.

Ao mesmo tempo, a presença das(os) estudantes gays, lésbicas, travestis, transexuais e heterodissidentes nas escolas Nós do Morro e Vozes parecem colocar em movimento o eixo da existência e da resistência que tensionam as intenções normatizadoras das práticas didático-curriculares. Nesse sentido, ainda que sobre esses corpos, a todo momento, estejam 
sendo direcionadas forças que busquem incluí-los na norma e na coerência entre sexo-gênero-desejo-orientação sexual, acreditamos que o próprio ato de se narrar a partir da escola apresenta-se como uma possibilidade de disputar a profusão discursiva refletida/produzida com/pelos currículos sobre gênero, sexualidade e educação.

\section{Referências}

ARROYO, M. Currículo, território em disputa. Petrópolis, RJ: Vozes, 2011.

BADINTER, E. XY. Sobre a identidade masculina. Rio de Janeiro: Nova

Fronteira, 1993.

BAUMAN, Z. Identidade: entrevista a Benedettoo Vecchi. Rio de Janeiro: Jorge Zahar, 2005 .

BLAZQUEZ GRAF, N. El retorno de las brujas. Ciudad de México, DF: UNAM/CEIICH, 2008.

BRITZMAN, D. O que é esta coisa chamada amor. Educação e Realidade, Porto Alegr, v. 2I, n. I, p. 7I-96, jan./jun. 1996.

BRITZMAN, D. Curiosidade, sexualidade e currículo. In: LOURO, G. (Org). O corpo educado: pedagogias da sexualidade. Belo Horizonte: Autêntica, 200I, p. 83- II2.

Trindade, E., \& Bruns, M. A. T. Adolescentes epaternidade: um enfoque fenomenológico. Ribeirão Preto, SP: Holos, 1999.

BUTLER, J. Problemas de gênero: feminismo e subersão da identidade. Rio de Janeiro: Civilização Brasileira. 2003.

CAETANO, M. Os gestos do silêncio para esconder as diferenças. 2005. $126 \mathrm{f}$.

Dissertação (Mestrado em Educação) - Universidade Federal Fluminenese, Niterói, 2005. 
CAETANO, M. Gênero e sexualidade: um encontro político com as epistemologias de vida e os movimentos curriculares. 20II. 228f. Tese (Doutorado em Educação) - Universidade Federal Fluminenese, Niterói 20 II. CAETANO, M. Performatividades reguladas: heteronormatividade, narrativas biográficas e educação. Curitiba: Appris, 2016.

CANDAU, V. (Org.). Somos tod@s iguais? Escola, discriminação e educação em direitos humanos. Rio de Janeiro: DP\&A, 2003.

CONNELL, R. Políticas de masculinidade. Educaşão e Realidade, Porto Alegre, v. 20, n. 2, p. 185-206, jul./dez. 1995 .

COSTA, J. O homoerotismo diante da Aids. In: PARKER, R. (Org). A aids no Brasil (I982-1992). Rio de Janeiro: Relume-Dumará: ABIA: IMS, UERJ, 1994. FRANCO, M. Pedagogia da Pesquisa-Ação. Educação e Pesquisa, São Paulo, v. 3I, n. 3, p 483-502, set./dez. 2005.

FOUCAULT, M. Vigiar e punir: nascimento da prisão. Petrópolis, RJ: Vozes, 1987.

FOUCAULT, M. História da sexualidade - a vontade de saber. Rio de Janeiro: ED. Graal, I988. v. I.

FOUCAULT, M. Microfísica do poder. Rio de Janeiro: Graal, 1979.

GOFFMAN, E. A representação do eu na vida cotidiana Petrópolis, RJ: Vozes, 1985.

MAFESSOLI, M. Homossocialidade: da identidade às identificações. Revista Bagoas: estudos gays, gêneros e sexualidade. Natal, v. I, n.I, p. I-Io. jul./dez. 2007.

Disponível em: <http://www.cchla.ufrn.br/bagoas/voinorartoI_maffesoli.pdf>. Acesso em: nov. 2016.

MISKOLCI, R. Um corpo estranho na sala de aula. In: ABRAMOWICZ, Anete; SILVÉRIO, V. (Org.) Afirmando diferenças: montando o quebra-cabeça da diversidade na escola. Campinas, SP: Papirus, 2005.

MOITA LOPES, L. Identidades fragmentadas: a construção discursiva de raça, gênero e sexualidade em sala de aula. Campinas, SP: Mercado das Letras, 2002. MOREIRA, A. (Org.). Currículo: questões atuais. Campinas, SP: Papirus, 1997. 
MOREIRA, A. Pesquisador em currículo. Organização e introdução Marlucy Alves Paraiso. BH: Autêntica, 2oIo. (Coleção Perfis da Educação, 2).

PENNYCOOK, A. Performance and performativity. In: PENNYCOOK, A.

Global Englisb's and Transcultural Flows. Nova York: Routledge, 2007. SCHOEN-FERREIRA, T. Adolescência através dos séculos. Psicologia: teoria e pesquisa. Brasília, v. 26, n. 2, p. 227-234, abr./jun. 20Io,

SILVA, T. T. da. Documentos de identidade: uma introdução às teorias de currículo. Belo Horizonte: Autêntica, 1999.

SILVA, T. T. da. Identidade e diferença: a perspectiva dos estudos culturais. Petrópolis-RJ: Vozes, 2000.

SILVA JR, P. Quando as questões de gênero, sexualidades, masculinidades e raça interrogam as práticas curriculares: um olhar sobre o processo de co/construção das identidades no cotidiano escolar. 20I4, 236f. Tese (Doutorado em Educação) Universidade Federal do Rio de Janeiro, Rio de Janeiro, 2014.

SILVA, T. T. da. O currículo com fetiche: a poética e a política do texto currículo. Belo Horizonte: Autêntica, 200I.

SULLIVAN, A. Praticamente normal: uma discussão sobre o homossexualismo. São Paulo: Companhia das Letras, 1996.

TREVISAN, J. Seis balas num buraco só: a crise do masculino. Rio de Janeiro: Record, 1998.

VEIGA, I. Projeto político-pedagógico: educação superior. Campinas, SP: Papirus, 2004 .

WELZER-LANG, D. A construção do masculino: dominação das mulheres e homofobia. Estudos Feministas, Florianópolis Ano 9, n. 46I, jul./dez.20oI. 


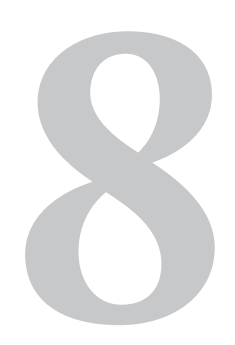

\section{Pedagogias do corpo: é possível a escola ser um espaço de reconstrução?

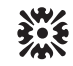 \\ Cássia Cristina Furlan Eliane Rose Maio}

\section{Introdução}

A escola contemporânea, em suas diversas nuances, tem abarcado diversidades ímpares em seu contexto social. Em seus desdobramentos, políticas e diretrizes,

${ }^{1}$ Essa pergunta sugere diferentes possibilidades de reconstrução. Abre-se às várias possibilidades de interpretação e possibilita questionarmos discursos produzidos na escola por décadas. A priori questionamos os reducionismos no modo de pensar com que as escolas têm trabalhado, partindo de pressupostos que desconsideram, em muitos aspectos, a diversidade presente em seu contexto, esquecendo-se de reconstruir sua prática, permeada por dogmas e preconceitos que criam invisibilidades e reproduzem discriminações. Não há o intuito de generalização, no entanto, deixamos a cargo da/o leitora/o a crítica ao universo escolar, produto da sociedade moderna em tempos pós-modernos. 
sugere buscarmos a construção de um espaço democrático, acolhedor, inclusivo e livre de preconceitos e discriminações. A pergunta que inicia essa discussão gira em torno de alguns "porquês". Por que não é possível ainda verificar esse espaço como sendo verdadeiramente inclusivo, acolhedor e livre de preconceitos? Por que as pessoas ditas diferentes ainda se sentem constrangidas ao expor uma identidade que foge à norma? Por que muitos(as) ainda se escondem por trás das roupagens aceitas pela cultura dominante? Se a escola é um espaço democrático, que postula em suas diretrizes essas políticas de inclusão, aceitação e respeito, por que é tão difícil permanecer? A luta é árdua. Muitas vezes somos sabotadas(os) em nossa caminhada, constrangidas(os), avaliadas(os), coagidas(os), magoadas(os), enfim, disciplinadas(os) e controladas(os) por essa cultura que insiste em disseminar o ódio e a opressão.

Nessa perspectiva, gostaríamos de problematizar essa noção de diversidade (SILVA, 20I4) que continua por reproduzir uma cultura dominante, por meio de processos de normalização e normatização de corpos, sexualidades e gêneros. Miskolci (2OI2) afirma que tolerar é muito diferente de reconhecer o outro, de valorizá-lo em sua especificidade, e conviver com a diversidade também não quer dizer aceitá-la. Temos uma noção de cultura estática, em que a diferença, o outro, deve manter-se rigidamente controlado, vigiado, para que possa se consolidar dentro da cultura dominante. A esse outro cabe a condição de abjeto a ser combatido, normalizado. "O outro é e não é. Desperta medo e curiosidade. Amamos e odiamos”. (SILVA, 20I4, p. 62)

Nesse contexto, posicionamo-nos na fronteira, no entre-lugar, no híbrido, no abjeto, para compor com essas representações um espaço de pertencimento minoritário, micropolítico, em um mundo que insiste em se (re)construir apesar das condições quase subumanas. Questionamos o corpo norma, aquele representante clássico das dicotomias subjacentes à nossa existência. Coadunamos com o pensamento de Donna Haraway (I994, p. 283), ao proclamar a célebre frase "prefiro ser um cyborg a ser uma deusa". 
O corpo é uma estratégia política, tanto das normatizações quanto das resistências. Precisamos assumi-lo como tal, para propor resistências aos corpos abjetos, provisórios, descontínuos, corpos queer, corpos políticos, corpos manifesto, corpos diversos, corpos nômades. Quebrar a ordenação das experiências de si requer uma luta contínua e ininterrupta, visando deslocar esses corpos formatados para uma experiência (im)previsível no mundo. Esse mundo que habitamos é um mundo de ambivalências, e como tal, exige que reconheçamos a existência de dissidências, de desejos destoantes que não cabem na experiência ordenada. Nesse sentido é que as discussões de gênero e pós-identitárias ganham relevo. Nesse período, a que muitos chamam pós-moderno, precisamos aprender a pensar de maneira diferente sobre nossa condição histórica e nos reinventar, como afirma Braidotti (2002). "Este projeto transformador começa com a renúncia aos hábitos de pensamento historicamente estabelecidos que, até agora, têm fornecido a visão "padrão" da subjetividade humana”. (BRAIDOTTI, 2002, p. 9)

De que lugar falamos? Que corpo estamos (re)produzindo? Que estratégias de opressão utilizadas por biopolíticas e biopoderes (FOUCAULT, 1997) estão sendo capturadas nesse cenário? Que subjetivações estamos construindo? A que corpos estão sendo submetidas essas estratégias biologizantes que visam formatá-los à norma? Estes são alguns questionamentos que a escola e aquelas(es) que dela participam devem cotidianamente fazer. Essas biopolíticas e biopoderes, controles dos corpos, experiências de si capturadas por estratégias de subjetivação dóceis precisam ser examinadas com cautela e compromisso ético. "As relações de poder-saber não são formas dadas de repartição, são 'matrizes de transformações”'. (FOUCAULT, ı988, p. 94)

\section{Corpos (in)dóceis: o corpo como estratégia política}

Há algum tempo tem se falado da questão da diversidade no ambiente escolar. Essa diversidade engloba uma série de corpos: indígenas, negros, 
mutilados, obesos, corpos queer, corpos híbridos, transgêneros, tímidos e diversos outros destoantes à norma(lidade), assim concebida pela cultura dominante.

Ao considerarmos o/a "nômade", como expressão dessas dissidências, pretendemos renunciar a posição confortável, em favor de uma visão descentralizada e multi-dimensionada do sujeito, em transformação constante. O "nômade" expressa as figurações de uma compreensão situada, culturalmente diferenciada de sujeito (BRAIDOTTI, 2002). "Subjetividade nômade tem a ver com a simultaneidade de identidades complexas e multi-dimensionadas. Falar como uma feminista acarreta o reconhecimento da prioridade do gênero, em estruturar essas relações complexas”. (BRAIDOTTI, 2002, p. IO, grifos da autora)
O sujeito nômade é um mito, ou ficção política, que me permite pensar sobre e mover-me através de categorias estabelecidas e níveis de experiência. Implícita na escolha desta figuração é a crença na potência e relevância da imaginação, da construção de mitos como um meio de sair da crise política e intelectual destes tempos pós-mo- dernos. Ficções políticas podem ser mais efetivas, aqui e agora, do que sistemas teóricos. A escolha de uma figura iconoclasta e mítica, tal como o sujeito nômade é, conseqüentemente, um passo contra a natureza estabelecida e convencional do pensamento teórico e espe- cialmente filosófico. (BRAIDOTTI, 2002, p. Io)

Ao nos posicionarmos no campo das teorizações que questionam a norma, nos consideramos também sujeitos nômades, na medida em que, de algum modo ou em algum local da cultura rompemos fronteiras, permanecemos na fronteira e/ou não nos localizamos em local algum. As identidades são fluídas, dependem da diferença, estão em estreita conexão com relações de poder, são diaspóricas, performativas, fragmentadas e fraturadas. (WOODWARD, 2000; SILVA, 2000; HALL, 2000) Sendo assim, não podemos considerar que existe uma única forma de representação identitária, ou representações binárias, visto que as identidades são 
construídas na e pela cultura e sofrem influências diversas que rompem com as classificações normatizadoras. Na concepção de Silva (2000, p. 82), "a mais importante forma de classificação é aquela que se estrutura em torno de oposições binárias, isto é, em torno de classes polarizadas”. Nesse sentido, consideram-se as ordenações, em torno das oposições binárias, masculino/feminino, branco/negro, homem/mulher, heterossexual/homossexual, identidades que são fixadas como norma e o seu oposto sofre processos de normalização e hierarquizações negativas. "A força homogeneizadora da identidade normal é diretamente proporcional à sua invisibilidade”. (SILVA, 2000, p. 83)

Interessante é perceber que muitos são os movimentos que conspiram para complicar e subverter a identidade. É um constante cruzamento de fronteiras, borramento de identidades e desestabilização das normas. Há um cultivo propositado de identidades ambíguas, tratando-se, pois, de uma estratégia política de questionamento das operações de fixação das identidades. (SILVA, 2000)

Portanto, ao defendermos o borramento das fronteiras pretendemos expor os processos culturais de construção das identidades, reafirmando a importância de não localizar identidades fixas e únicas, mas construções performáticas e mutantes, em processos constantes de deslocamentos e subversões.

Caetano (2014) afirma que devemos considerar o corpo como lócus central e inicial de produção e expressão da cultura, pois é nele que as identidades são elaboradas e significadas. Além disso, são diversos os discursos proliferados (FOUCAULT, I999) que produzem significações, proibições, incitações que demarcam incessantemente o nosso corpo, permeado por relações de poder.

Quando incitamos a colocação do sexo em discurso, das questões de gênero, da produção de subjetividades, das sexualidades disparatadas, estamos propondo analisar discursos que produzem verdades e deslocam significados, dispondo os sujeitos em um emaranhado de produções discursivas. Entretanto, como Foucault (I999, p. 36-37) afirma, nem todas 
as regiões do discurso são igualmente abertas e penetráveis, “[...] algumas são altamente proibidas (diferenciadas e diferenciantes), enquanto outras parecem quase abertas a todos os ventos e postas, sem restrição prévia, à disposição de cada sujeito que fala”.

Em torno do sexo, das sexualidades e dos gêneros há uma verdadeira explosão discursiva (FOUCAULT, 1988), no entanto, essa explosão, muitas vezes, acaba por incitar um discurso regulado e polimorfo, ou seja, um discurso que produz normas, produz diferenças vigiadas e limita as formas de vivências identitárias, na medida em que sugere normalidades e submete ao apagamento as identidades que se furtam da aceitação de imposições identitárias. Todavia, como nos apresenta Foucault (I988, p. 48), mesmo que esse discurso “[...] se apoie localmente em procedimentos de interdição, ele assegura, através de uma rede de mecanismos entrecruzados, a proliferação de prazeres específicos e a multiplicação de sexualidades disparatadas”.

Alguns dispositivos de poder exercem-se para regular a propagação dos discursos da sexualidade, criando a norma e o abjeto, proliferando dissidências para controlá-las. A exemplo, o dispositivo da sexualidade

$[\ldots .$.$] funciona de acordo com as técnicas móveis, polimorfas e conjun-$
turais de poder. [...] engendra, em troca, uma extensão dos domínios
e das forças de controle. [...] se liga à economia através de articulações
numerosas e sutis, sendo o corpo a principal - o corpo que produz
e consome. [...] tem como razão de ser, não o reproduzir, mas o pro-
liferar, inovar, anexar, inventar, penetrar nos corpos de maneira cada
vez mais detalhada e controlar as populações de modo cada vez mais
global. [...] a sexualidade está ligada a dispositivos recentes de poder.
(FOUCAULT, I988, p. IOI)

Nesse sentido, como propõe Foucault (1988, p. I47), "contra o dispositivo de sexualidade, o ponto de apoio do contra-ataque não deve ser o sexo-desejo, mas os corpos e os prazeres". Para o autor (FOUCAULT, 1997), a verdade não existe fora do poder ou sem poder, ela é produzida e produz efeitos regulamentados de poder. Cada sociedade tem seu regime 
de verdade, ou seja, tipos de discurso que ela acolhe e faz funcionar como verdadeiros, distinguindo-os dos falsos. Nesse sentido, Butler (2003, p. I95) questiona,

[...] se a verdade interna do gênero é uma fabricação, e se o gênero verdadeiro é uma fantasia instituída e inscrita sobre a superfície dos corpos, então parece que os gêneros não podem ser nem verdadeiros nem falso, mas somente produzidos como efeitos da verdade de um discurso sobre a identidade primária e estável.

Sendo assim, a nossa sociedade, incessantemente, insiste em afirmar algumas verdades postuladas historicamente com relação às identidades de gênero e sexualidades. Haverá alguns pontos de resistência nesse discurso? Sem dúvida, pois as relações de poder que se estabelecem na sociedade são desiguais e móveis, e logo, não há uma oposição binária e global entre aqueles que dominam e os/as dominados/as. Portanto,

[...] onde há poder há resistência e, no entanto (ou melhor, por isso mesmo) esta nunca se encontra em posição de exterioridade em relação ao poder. [...] Elas não podem existir senão em função de uma multiplicidade de pontos de resistência que representam, nas relações de poder, o papel de adversário, de alvo, de apoio, de saliência que permite a preensão. Esse pontos de resistência estão presentes em toda a rede de poder. [...] resistências, no plural, que são casos únicos: possíveis, necessárias, improváveis, espontâneas, selvagens, solitárias, planejadas, arrastadas, violentas, irreconciliáveis, prontas ao compromisso, interessadas ou fadadas ao sacrifício; [...] Elas são o outro terma nas relações de poder. (FOUCAULT, i988, p. 89-9I)

Resistências, dissidências, nomadismos, transformações. Nesse caminho seguimos lutando, pois sempre que há um ponto de opressão, há formas de resistência. Quando consideramos as desigualdades de gênero, tão em voga nos discursos atuais, tanto midiáticos quanto acadêmicos, ressaltamos a importância de propor debates intensos com relação à proliferação de discursos biologizantes, que insistem em negar que nos 
construímos culturalmente. Como diz Louro (2007), não há, contudo, a pretensão de negar que o gênero se constitui com ou sobre os corpos sexuados; não se nega a biologia, mas enfatiza-se a construção social e histórica que, para além da biologia, há uma imensidão de possibilidades de construir-se enquanto indivíduos e que essa construção nem sempre se dá na direção esperada por grande parte conservadora da sociedade (sexo/ gênero/sexualidade e suas derivações heteronormativas).

Um novo tipo de política feminista é desejável nesses novos tempos, pois noções estáveis de gênero não servem mais de premissa básica. É preciso contestar as próprias reificações do gênero e da sexualidade. (BUTLER, 2003) '[...] certos tipos de 'identidade de gênero' parecem ser meras falhas do desenvolvimento ou impossibilidades lógicas, precisamente porque não se conformarem às normas da inteligibilidade cultural”. (BUTLER, 2003, p. 39) É preciso que o corpo, saturado por relações de poder, construa-se enquanto pontos de resistências. Corpos como estratégia política, na medida em se recusam a reproduzir discursos, fogem às classificações, usam-se como instrumento de poder.

Para a autora, a distinção sexo/gênero e a própria categoria sexual parecem pressupor uma generalização do corpo à aquisição de seu significado sexuado. No entanto, esse corpo não é passivo, é construído por meio de discursos, experiências e práticas que dão significação, criam subjetivações e moldam os sujeitos. Ou seja, a generalidade desse corpo passivo é suspeita.

A produção do corpo “abjeto", tornado literalmente o "Outro", estabelece as fronteiras do corpo, que são também os primeiros contornos do sujeito. (BUTLER, 2003) Afirma a autora,

a construção da coerência oculta as descontinuidades do gênero, que grassam nos contextos heterossexuais, bissexuais, gays e lésbicos, nos quais o gênero não decorre necessariamente do sexo, e o desejo, ou a sexualidade em geral, não perece decorrer do gênero - nos quais, a rigor, nenhuma dessas dimensões de corporeidade significante expressa ou reflete outra. Quando a desorganização e desagregação do 
campo dos corpos rompe a ficção reguladora da coerência heterossexual, parece que o modelo expressivo perde sua força descritiva. O ideal regulador é então denunciado como norma e ficção que se disfarça de lei do desenvolvimento a regular o campo sexual que se propõe descrever. (BUTLER, 2003, p. 194)

Vemos o sexo e o gênero desnaturalizados, corpos abjetos que se tornam performáticos, que confessam sua distinção e dramatizam o mecanismo cultural da sua unidade fabricada. Para a autora, assim como as superfícies corporais são impostas como o natural, elas também podem se tornar o lugar da performance dissonante e desnaturalizada, que revela inclusive o status performativo do próprio natural, questionando as verdades postuladas acerca dessa naturalidade.

Devemos pensar as táticas de poder que, permeando a escola, impõem situações de preconceitos e permitem também desvelar esses mecanismos, produzindo estratégias de oposição. Na escola, corpos dóceis e úteis foram produzidos (SILVA, 20I4), vemos acontecer o apagamento do outro, o borramento da diferença, por meio de políticas inclusivas, de práticas de tolerância, de afirmação do multiculturalismo. "É possível, também, ver na escola o controle, o despojamento, a preservação e a verdade do outro transformado em mesmo". (SILVA, 20I4)

Nesse sentido é que devemos duvidar de regimes de verdade (FOUCAULT, I999), questionando o investimento político e do poder sobre o corpo e as experiências das sexualidades e gêneros. Guacira Lopes Louro (1999) apresenta que a escola sempre teve como objeto a escolarização de corpos e sexualidades. Nesse sentido, sempre praticou pedagogias das sexualidades, dos gêneros e dos corpos. Ela deixa marcas no corpo ao discipliná-lo e, disciplinarizando-o, o mediu, avaliou, examinou, coagiu, magoou e o categorizou.

Para Le Breton (20I4), o corpo é uma forma simbólica, um universo de significados e valores constantemente reencenados, constantemente em movimento. Sendo assim, torná-lo uma ferramenta de resistência, um ato político, rompe fronteiras e possibilita a reconstrução das experiências 
de si como práticas de liberdade. Tornemo-nos nômades de nosso próprio corpo para figurar contra essas amarras que nos aprisionam e nos impedem de ser quem somos e/ou gostaríamos de ser.

\section{Pedagogias do corpo, papel docente e a (re)construção de saberes no espaço escolar}

Ao nos construirmos como sujeitos nômades, reafirmamos a pluralidade de experiências que nos hibridizam enquanto sujeitos políticos. As performances normativas só existem na medida em que estabelecemos as fronteiras e repetimos incessantemente normas de comportamentos como absolutos. (LE BRETON, 20I4)

Nessa perspectiva, para uma escola efetivamente acolhedora e que produza espaços plurais e aceite a diversidade como constituinte dos nossos tempos, precisamos constantemente reafirmar a multiplicidade de formas de nos construirmos, em vários estilos, algumas vezes até mesmo contraditórios. "A identidade de gênero, imersa no sentimento de identidade do indivíduo, é maleável, movediça, múltipla, simples proposta eventualmente revogável”. (LE BRETON, 20I4, p. 20) O autor traz que

\footnotetext{
a movência transgênero traduz, inversamente, a recusa dos binarismos, em especial, homossexual/heterossexual, homem-mulher, masculino-feminino, e anuncia a vontade de problematizar as diferenças, de multiplica-las ao invés de organizá-las em categorias instáveis e preestabelecidas. (LE BRETON, 20I4, p. 20-2I)
}

A movência transgênero reflete o questionamento às normas, a maleabilidade da construção das identidades e a reflexão acerca dos binarismos, de modo que reconstrua outra perspectiva de sujeito, que não precise se classificar, que possa transitar entre as identidades que lhe proporcionam bem-estar e que seja aceito e respeitado em suas particularidades.

Nesse sentido, o gênero torna-se um vasto campo de experimentos, de libertações e inversões que põe em dúvida a legitimidade das identidades 
construídas no e sobre os corpos sexuados. Na sociedade em geral, esses corpos que descontroem a coerência entre sexo, gênero, desejo e prática sexual são considerados abjetos. Para autores(as) como Butler (2003), o abjeto é aquele excluído socialmente com sexualidade transgressora e que luta por existir orientado por uma agenda política. (ARAUJO, 20I4) "Abjeção (no latim, ab-jicere) significa literalmente excluir, jogar fora ou longe e, portanto, pressupõe e produz um domínio de agência do qual é diferenciado" (SANTOS, 20I3, p. 77). A sociedade, ao temer identidades que são produzidas fora da norma, desviantes do padrão aceito, reproduzem constantemente a estratégia heteronormativa para fugir destes temores, criando a abjeção desses corpos e práticas. (SANTOS, 2013)

A transformação do 'outro' em um absoluto e essencializado é parte dessa estratégia socialmente construída e reiteradamente performatizada de divisão binária e dicotômica entre os sexos e que serve, no fundo, à constituição e universalização do sujeito ocidental. (CAETANO, 20I4, p. 49)

Desse modo, a escola comprometida com a formação social, deve (ou deveria) pautar-se na desconstrução dos paradigmas assentados na modernidade que reafirmam a presença do abjeto empurrando-o para as zonas de apagamento. Corpos abjetos são todos os tipos de corpos cujas vidas não são consideradas vidas e cuja materialidade é entendida como não importante (SANTOS, 20I3), como corpos gordos, mutilados, recortados, queer, transgêneros. Por isso, ao nos comprometermos com a formação consciente, devemos lutar contra imposições binárias, hierarquizadas, produtora de dissidências, apostando no devir, na solidariedade e na ética das relações sociais. Essa é uma questão política e, como tal, deve levar ao exercício da resistência (ARAUJO, 20I4).

Algumas(uns) teóricas(os) (Butler (2003), Cesar (2008) e Preciado (20II), dentre outras(os) propõem uma reivindicação que desconstrua a perspectiva normatizadora das políticas de identidade. A Teoria Queer, como ficou conhecida, apresenta ameaças a qualquer normativa hegemônica, 
os corpos abjetos, pensados como uma "multidão queer" (PRECIADO, 20II) possuem essencialmente um potencial transgressor.

Surgidos no bojo das produções teóricas que questionam os saberes hegemônicos e, para tanto, enfocam a historicidade das relações e dinâmicas sociais partindo de perspectivas não ou contra hegemônicas que deixam exposto o caráter e o envolvimento político desses mesmos estudos com seus contextos, os Estudos Queer, entre outros objetivos, buscam estranhar as normas sociais opressivas que se encontram naturalizadas. Para tanto, juntamente com os Estudos das Subalternidades e os Estudos Pós-Coloniais, dão voz e visibilidade a um largo segmento da sociedade que está nas margens em razão da ininteligibilidade de seus desejos e/ou práticas para aqueles que se localizam na norma ou em suas imediações. (CYSNEIROS, 20I3, p. 192-193)

Para Le Breton (20I4, p. 26), "a reivindicação genderqueer liberta de toda e qualquer ancoragem biológica ou convenção social e inventa um indivíduo sem fronteiras de gênero, que faz implodir as práticas sexuais”. Ela visa a perturbar o gênero, a deslocar o sistema tradicional gênero-sexo.

Nesse sentido, gêneros são constituídos performaticamente e, quando se produz a binaridade entre os gêneros, o que se pretende é que efeitos de verdade sejam postos em evidência, para que continuem a reproduzir normas e discursos biológicos e dualistas.

Ao considerarmos o hibridismo como um "terceiro espaço" (CYSNEIROS, 20I3), visamos possibilitar o surgimento de outras posições, que deslocam as histórias que estabelecem estruturas de autoridades, permitindo novas iniciativas políticas que se conduzam na direção da negação às heteronormatividades.

O pensamento queer deveria fazer parte do conjunto de ideias que perpassam o ambiente escolar, pois como um projeto político se propõe a construir um espaço de desestabilização, subversão e emancipação nas construções identitárias, sobretudo quando tratamos das questões de gênero e sexualidade. Problematiza os papéis tidos como estáticos de ho- 
mens e mulheres, héteros e homos até o ponto em que rompe com tais binômios explorando suas incoerências (LIMA, 20I3).

A teoria queer não ambiciona, tal como o faz boa parte dos estudos da diáspora, encontrar uma "origem”, mas sim demonstrar que sujeitos queer, ou sujeitos outros e outros sujeitos são parte do que se poderia chamar de "cultura planetária", que acarretaria, segundo entendo, a formação de novos vínculos e a constituição de uma nova "fraternidade" - uma ética - calcada na sexualidade e/ou na performatividade de gênero [...]. (LIMA, 20I3, p. 278)

Ao questionarmos a heterossexualidade compulsória e as heteronormatividades, ${ }^{2}$ questionamos as normas que nos obrigam a repetir os mesmos atos, gestos e atuações que estabilizam um corpo binário e enquadrado a um modelo social.

Citando essas normas que regulam as vidas e os desejos, Colling (2013, p. 96), de forma resumida, aponta alguns pensamentos de Judith Butler (2008):

I) os corpos são efeitos de uma dinâmica de poder; 2) a performatividade é um ato do poder reiterado do discurso; 3) a construção do sexo é uma norma da cultura que governa a materialidade dos corpos; 4) o "eu" que assume um sexo é formado por esse processo de assumir um sexo, que é desde sempre regulado; 5) o imperativo da heterossexualidade possibilita certas identificações sexuadas e impede ou nega outras, mecanismo através do qual produz os seres considerados abjetos, aqueles que não são propriamente generificados, humanizados, que não gozam do status de sujeitos. A política

2 Assim, Butler defende que, além de obrigar que sejamos todos heterossexuais (heterossexualidade compulsória) ou que, mesmo que não sejamos heterossexuais, pelo menos estejamos enquadrados dentro das normas tidas como heterossexuais (heteronormatividade), a sociedade também nos obriga a ter um gênero tido como compatível com a materialidade dos nossos corpos. E essas exigências, realizadas através de atos, gestos e atuações, são performativas, pois criam os sujeitos que enunciam. Para que essas ações tenham êxito é necessário que elas sejam constantemente repetidas e vigiadas. (COLLING, 2013, p .90) 
feminista e queer, defende Butler, pode promover a desidentificação com essas normas regulatórias que materializam a diferença sexual.

Nesse sentido, o gênero não é mais colocado como dualidade, mas como um acúmulo de possibilidades, ele é apenas um recurso a ser usado de modo criativo, não nos obrigando a repetir normas. $\mathrm{O}$ processo de desconstrução desses binarismos é profundamente político e marca a produção dos corpos, no sentido de problematizar a perspectiva dominante. $\mathrm{Na}$ concepção de Le Breton (20I4), a biologia é um capítulo do político, na medida em o sexo e o corpo são cristalizações de significados sociais, são corpos escritos no plural e, portanto, não podem ser reduzidos a meras inscrições biológicas. Entretanto, infelizmente muitos(as) ainda fracassam em traduzir essa pluralidade, pois dispõem apenas de classificações binárias para designar essas categorias.

Por conseguinte, coadunamos com o exposto por Judith Butler (2003, p. 213), ao trazer que

a desconstrução da identidade não é a desconstrução da política; ao invés disso, ela estabelece como políticos os próprios termos pelos quais a identidade é articulada. Esse tipo de crítica põe em questão a estrutura fundante em que o feminismo, como política de identidade, vem-se articulando. [...] A tarefa aqui não é celebrar toda e qualquer nova possibilidade qua possibilidade, mas redescrever as possibilidades que já existem, mas que existem dentro de domínios culturais apontados como culturalmente ininteligíveis e impossíveis. Se as identidades deixassem de ser fixas como premissas de um silogismo político, e se a política não fosse mais compreendida como um conjunto de práticas derivadas dos supostos interesses de um conjunto de sujeitos prontos, uma nova configuração política surgiria certamente das ruínas da antiga.

Sendo assim, como todo sistema de educação é uma maneira política de manter ou de modificar a apropriação dos discursos (FOUCAULT, 1999), as escolas podem e devem problematizar os significados constituídos 
sobre as identidades, pois essas marcas de gêneros e sexualidades não marcam apenas os corpos, mas o social, o político, o religioso, o cotidiano.

Nesse sentido, como propõe Hall (2006), consideremos o corpo como uma "tela de representação", ensaiando novas possibilidades e alternativas em suas materialidades performáticas. As marcas inscritas nos corpos são cotidianas nas escolas, constituindo-se enquanto uma instituição que regula e produz significados sobre os corpos imprimindo nele valores culturais. Devemos, nessa ótica, constantemente problematizar os conhecimentos que são eleitos para serem ensinados nas escolas. (CAETANO, 20I4) O gênero não é uma simples categoria analítica, mas o fazer e desfazer de corpos num mundo contraditório, em movimento, envolto por relações de poder.

Destarte, consideremos as palavras de Foucault (1997, p. 137), ao pensar no intelectual necessários a esses tempos pós-modernos:

\begin{abstract}
sonho com o intelectual destruidor das evidências e das universalidades, que localiza e indica nas inércias e coações do presente os pontos fracos, as brechas, as linhas de força; que sem cessar se desloca, não sabe exatamente onde estará ou o que pensará amanhã, por estar muito atento ao presente; que contribui, no lugar em que está, de passagem, a colocar a questão da revolução, se ela vale a pena e qual (quero dizer qual revolução e qual pena). Que fique claro que os únicos que podem responder são os que aceitam arriscar a vida para fazê-la.
\end{abstract}

Será que estamos dispostos(as) a arriscar a vida por uma revolução que desestabilize as verdades e mostre suas incoerências e brechas? É desse(a) intelectual que precisamos, para que haja tal movimento de transformação que possibilite a construção de novas sociedades e/ou novos modos de estabelecer as relações, possibilitando agir com solidariedade e consciência crítica das diversidades e seu pertencimento à nossa sociedade.

Envolvidas na perspectiva freireana, atrevemo-nos a acreditar em uma utopia, uma mudança de paradigmas no campo educacional, visando a consolidar o papel ético e responsável de quem educa, o que se faz dentro 
e fora dos moldes escolares. Acreditamos nas palavras de Paulo Freire (1996) quando nos fala que uma das condições para pensar certo é não estarmos certos de nossas certezas. Como traz Freire (1996, p. 17),

é próprio do pensar certo a disponibilidade ao risco, a aceitação do novo que não pode ser negado ou acolhido só porque é novo, assim como o critério de recusa ao velho que não é apenas o cronológico.

[...] Faz parte igualmente de pensar certo a rejeição mais decidida a qualquer forma de discriminação. A prática preconceituosa de raça, de classe, de gênero ofende a substantividade do ser humano e nega radicalmente a democracia. Quão longe dela nos achamos quando vivemos a impunidade dos que matam meninos nas ruas, dos que assassinam camponeses que lutam por seus direitos, dos que discriminam os negros, dos que inferiorizam as mulheres.

Qualquer discriminação é imoral e lutar contra ela, para o autor, é um dever, por mais que se reconheça a força dos condicionamentos a enfrentar. Condicionamentos esses que podem estar atrelados a preconceitos em relação à etnia, à classe, aos gêneros, à sexualidade, e que precisam ser quebrados por meio da luta contra todas as formas de discriminação.

Às vezes sem perceber, a escola interfere na construção das identidades de gênero e sexualidade de cada aluno(a), por isso é necessário que ela reflita acerca do seu papel quanto à importância de tratar desses assuntos, e de fazê-lo com responsabilidade ética, respeitando e ensinando a respeitar todas as formas de construções identitárias. Como explicitam França e Calsa (2007), a escola pode favorecer a compreensão mais elaborada dos conflitos e tensões de gênero e de sexualidade que perpassam as relações de poder da sociedade.

Nesse aspecto, para que a educação nas instituições de ensino possa ter uma outra face possível, é preciso que os docentes, a coordenação, a equipe pedagógica e a comunidade transformem suas ações, trabalhando em prol de uma ação política e pedagógica que adote a questão de gênero e sexualidade como necessária para entender a educação (SARAIVA, 2002). 
Consideramos de suma importância uma posição alicerçada em Paulo Freire (1975; 1997) e que nos é bastante singular: o fundamento da denúncia e do anúncio mostra-nos uma possibilidade de reflexão, transformação da realidade e construção de um lugar mais justo e solidário.

[...] a denúncia de como estamos vivendo e o anúncio de como poderíamos viver. É um pensamento esperançoso, por isso mesmo. É neste sentido que [...] não apenas fala do que pode vir, mas, falando de como está sendo a realidade, denunciando-a, anuncia um mundo melhor. (FREIRE, I997, p. II8)

Mulheres e homens se tornam seres éticos por sua capacidade de comparar, valorar, intervir, escolher, decidir e de romper, romper com situações que não possibilitem o respeito à natureza do ser humano. Educar, para Paulo Freire (1996), é substancialmente formar.

\section{Algumas reflexões}

Algumas inquietações nos fazem questionar as atuais estruturas impostas, que foram construídas historicamente e que, dia a dia, reafirmam-se enquanto dogmas e preceitos que desautorizam e/ou tentam desautorizar discursos de igualdade e respeito às diversidades. Estando inseridos no espaço escolar, enquanto parte do corpo docente, percebemos a todo o momento esses discursos que deslegitimam as lutas e uniformizam causas como superficiais e inúteis ao ambiente escolar.

Incluir-se na gama das diversidades nos coloca em "maus lençóis", visto que, para além dos constrangimentos diversos, somos também desautorizados a falar, a expor nossas lutas. É preciso que sejamos fortes e conscientes do nosso papel político, visto que como educadores e educadoras, temos uma função social. A escola tanto pode dar continuidade a preconceitos e estereótipos como favorecer a criação de espaços em que se discutam as diferenças e o respeito às diversidades. Essa instituição tem muito a fazer pelas crianças. Questionar é difícil, exige reflexão crítica e exige vontade, exige querer. É preciso ultrapassar o senso comum 
para, no amplo plano das possibilidades, engendrar outras realidades e novos horizontes emancipatórios. Porém, o questionar, a reflexão crítica, a vontade, o querer parecem ainda em estado de latência, carecendo de motivos para aflorar, diante de realidades ainda tão censuradas por muitos, como são as de gêneros e, mais ainda, as de sexualidades.

Precisamos pensar em um currículo e uma pedagogia da diferença que desestabilizem verdades ditas absolutas, colocando em xeque hibridismos, nomadismo, cruzamentos de fronteiras, ou seja, que favoreça formas de experimentação e respeite toda e qualquer diversidade. Possuímos em nosso contexto uma multiplicidade de experiências que não podem ser reduzidas a normas específicas. Esse processo precisa ser contínuo e é importante para a quebra de paradigmas no campo dos gêneros, sexualidades e suas diversas possibilidades.

\section{Referências}

ARAÚJO, D. B. de. Para uma nova perspectiva e visibilidade política de velhas questões. Periódicus, Salvador, v. I, n. I, maio/out. 20I4. Disponível em: <www. portalseer.ufba.br/index.php/revistaperiodicus/index>. Acesso em: jan. 2015.

BRAIDOTTI, R. Diferença, diversidade e subjetividade nômade. Labrys, Estudos Feministas, n. I-2, jul./dez. 2002. Disponível em: <http://www.unb.br/ih/ his/gefem>. Acesso em: 2 mar. 2012.

BUTLER, J. Problemas de gênero: feminismo e subversão da identidade. Rio de Janeiro: Civilização Brasileira, 2003.

BUTLER, J. Cuerpos que importan. Sobre los limites materiales y discursivos del "sexo". Buenos Aires: Paidós, 2008.

BUTLER, J. Corpos que pesam: sobre os limites discursivos do sexo. In:

LOURO, G. L. O corpo educado: pedagogias da sexualidade. Belo Horizonte: Autêntica, 200I. 
CAETANO, M. "Não se nasce mulher" - ela é performatizada: sexo, política e movimentos. FERRARI, A.et. al. (Org.). Corpo, gênero e sexualidade. Lavras: UFLA, 20I4. p. 37-58.

CESAR, Maria Rita de Assis. Quatro intervenções para uma pedagogia queer. In: REUNIÃO ANUAL DA ANPED, 3I., 2008, Caxambu. Anais eletrônicos..., Caxambu, 2008. Disponível em: <http://3rreuniao.anped.org.br/Itrabalho/ GT23-46I4--Int.pdf.> Acesso em: i jan. 2010.

COLLING, L. Mais visíveis e mais heteronormativos: a performatividade de gênero das personagens não-heterossexuais nas telenovelas da Rede Globo. COLLING, L.; THÜRLER, D. (Org.). Estudos e política do CUS - Grupo de Pesquisa Cultura e Sexualidade. Salvador: Edufba, 2013, p. 87-98.

CYSNEIROS, A. Enxergando através do armário: corpos, margens e sexualidades policiadas. COLLING, L.; THÜRLER, D. (Org.). Estudos e política do CUS - Grupo de Pesquisa Cultura e Sexualidade. Salvador: Edufba, 2013. p. 193-218.

FOUCAULT, M. História da sexualidade I: a vontade de saber. Rio de Janeiro: Graal, 1988.

FOUCAULT, M. Microfísica do poder. II. ed., Rio de Janeiro: Graal, 1997. Disponível em: <http://filoesco.unb.br/foucault/>. Acesso em: or maio 2008. FOUCAULT, M. A ordem do discurso. São Paulo: Edições Loyola, 1999.

FRANÇA, F. F.; CALSA, G. C. As contribuições dos estudos de gênero e sexualidade no cotidiano escolar dos docentes. In: FAZENDO GÊNERO: CORPO, VIOLÊNCIA E PODER. 8., 2008, Florianópolis. Anais eletrônicos... Florianópolis, 2008. Disponível em: <http://www.fazendogenero.ufsc.br/8/sts/ ST 40/Franca-Calsa_40.pdf >. Acesso em: 4 jan. 2012.

FREIRE, P. Pedagogia do oprimido. I7. ed. Rio de Janeiro: Paz e Terra, 1975.

FREIRE, P. Pedagogia da autonomia: saberes necessários à prática educativa. 25. ed. São Paulo: Paz e Terra, 1996.

FREIRE, P. Pedagogia da esperança: um reencontro com a pedagogia do oprimido. Rio de Janeiro: Paz e Terra, 1997.

HALL, S. Quem precisa de identidade? SILVA, T. T. da (Org.); HALL, S.; WOODWARD, K. Identidade e diferença: a perspectiva dos estudos culturais. Petrópolis/RJ: Vozes, 2000. p. IO3-I33. 
HALL, S. Da diáspora: identidades e mediações culturais. Belo Horizonte: Editora da UFMG, 2006.

HARAWAY, D. Um manifesto para os cyborgs: ciência, tecnologia e feminismo socialista na década de 80 . HOLLANDA, H. B. Tendências e impasses: o feminismo como crítica da cultura. Rio de Janeiro: Rocco, 1994. p. $243-288$.

LE BRETON, D. Corpo, gênero, identidade. In: FERRARI, Anderson et. al. (Org.). Corpo, Gênero e Sexualidade. Lavras: UFLA, 20I4, p. 19-32.

LIMA, C. H. L. Feminismos, estudos literários e epistemologia queer imbricamentos. COLLING, Leandro; THÜRLER, Djalma (Orgs.). Estudos e política do CUS - Grupo de Pesquisa Cultura e Sexualidade. Salvador: Eduf ba, 2013, p. $263-286$.

LOURO, G. L. Pedagogias da sexualidade. LOURO, G. L. (Org.). O corpo educado: pedagogias da sexualidade. Belo Horizonte: Autêntica, I999, p. 7-34. LOURO, G. L. Gênero, sexualidade e educação: uma perspectiva pósestruturalista. Petrópolis/RJ: Vozes, 2007.

MISKOLCI, R. Teoria Queer: um aprendizado pelas diferenças. 2. ed. Belo Horizonte: UFOP, 2012.

PRECIADO, B. Multidões queer: notas para uma política dos anormais. Estudos Feministas. Florianópolis, 20II.

SANTOS, M. A. dos. Abjeto em disputa: dissidências ou não entre Bataille, Kristeva e Butler. COLLING, L.; THÜRLER, D. (Org.). Estudos e política do CUS - Grupo de Pesquisa Cultura e Sexualidade. Salvador: Edufba, 2013, p. $6 \mathrm{I}-85$.

SARAIVA, M. do C. Porque investigar as questões de gênero no âmbito da educação física, esporte e lazer? Motrivivência, Florianópolis: UFSC, v. I3, n. I9, p. $87-95$, dez/2002.

SILVA, T. T. da. A produção social da identidade e da diferença. SILVA, T. T. da; HALL, S.; WOODWARD, K. (Org.). Identidade e diferença: a perspectiva dos Estudos Culturais. Petrópolis/RJ: Vozes, 2000, p. 73-IO2. 
SILVA, E. P. de Q. Entremeando corpos, sexualidade, gêneros e educação escolar. In: FERRARI, A. et. al. (Org.). Corpo, gênero e sexualidade. Lavras: UFLA, 20I4. p. 6I-78.

WOODWARD, K. Identidade e diferença: uma introdução teórica e conceitual. SILVA, Tomaz Tadeu da (Org.); HALL, S.; WOODWARD, K. Identidade e diferença: a perspectiva dos Estudos Culturais. Petrópolis/RJ: Vozes, 2000. p. 7-72. 


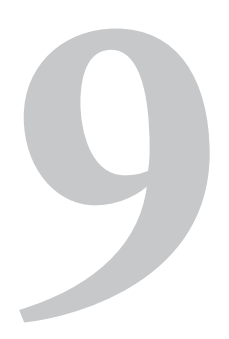

\title{
"Nem toda a gente gosta do diferente":
}

\author{
literatura, (de)formação do
}

leitor e diversidade ${ }^{\mathrm{I}}$

\author{
渵 \\ Emerson Inácio
}

Em seu ensaio A literatura e a formação do bomem, o crítico literário Antonio Candido conduz o foco de seu pensamento para a função humanizadora que a literatura tem a capacidade de cumprir na vida das pessoas, enfatizando sempre que aquela forma estético-discursiva favoreceria à percepção, pela leitura, do quão podem

${ }^{1}$ O título desse ensaio provém de um verso de "Como Tu", da poetisa portuguesa Ana Luísa Amaral, longo poema em que, pressupondo que seu leitor trata-se de crianças, a autora discute, de maneira singela, a questão das diferenças identitárias e sobre como o afeto é capaz de superá-las. 
ser e se tornar sensíveis são as pessoas em função da leitura de um texto literário. Candido, de certa forma, acompanha neste ensaio a concepção oitocentista - e permanente ainda em certa medida - de que o texto literário traria em si, de certa forma, uma capacidade "formadora”, ou seja, de fazer redundar dela indivíduos melhores, conscientes dos grandes valores sociais, morais e humanos necessários à existência das famílias e da sociedade. Entretanto, hoje sabemos que, diferentemente daquilo em que se acreditou por muitos séculos, o texto literário e a "instituição" literatura não tem nem culturalmente nem politicamente o peso que teve durante boa parte da história da escrita e da leitura. Pelo contrário, hoje em dia concorre com outros suportes, cuja capacidade de formar, indubitavelmente, é bem mais eficaz que a forma escrita da linguagem e, porque não dizer, muitas vezes bem mais acessível que um objeto como o livro.

Estaria apenas reforçando o ideário defendido por Candido se eu dedicasse este meu exercício a valorar o texto literário na sua intencionada ou não capacidade de interferir na conformação da cidadania. Interessame, ao par disso, pensar a função reformadora ou, talvez, deformadora que a literatura tem, não só de se demarcar como uma outra linguagem distinta das mídias e suportes mais usuais, mas sobretudo como forma de linguagem em que se estabelece também a diferença: pela exposição daquilo que o senso comum majoritário consideraria não literário, não digno de representação e antissublime é a que a literatura, efetivamente, hoje se faz. Assim, não desejo aqui discutir nem o suposto adultério de Capitu nem sequer os trágicos perigos a que Luísa fora exposta ao dedicar parte dos seus dias à leitura dos romances românticos oitocentistas, mas, pelo contrário, observar como o texto literário pode, a partir dos "restos" sociais e culturais, do erótico, do inusitado, do transgressivo, e mesmo da exposição de formas outras de afeto, propor uma deformação dos leitores, capacitando-os a perceberem a existência de discursos baseados na diferença e na diversidade em todos os seus âmbitos. Aqui entendo por "deformação" uma noção que vai além da perda da forma, mas sim como um procedimento necessário à formação dos indivíduos para que percebam a 
capacidade da linguagem de, saindo dos eixos, transbordando, indo além dos formatos pré-estabelecidos, ensejar a construção de juízos críticos a cerca do mundo.

Noutras palavras: a literatura pode ir além da "função humanizadora" apontada pelo crítico literário e sociólogo Antonio Candido, favorecendo, a partir dessa capacidade de deformação, a construção de discursos que contribuam para sistemas de igualdade, tolerância e respeito às diferenças sejam elas quais forem, não só no âmbito escolar, mas no universo maior da cultura no qual a literatura está discursiva e esteticamente inscrita. Nesse sentido, e palmilhando obras como a de António Botto ( $O$ Livro das Crianças e Histórias do arco da velba) e Ana Luísa Amaral ( $A$ tempestade e Como tu), bem como outros autores, brasileiros inclusive, que trazem ao corpo de sua produção a problematização e/ou as tensões de gênero e sexualidade, pretende-se, assim, entender como o cânone literário pode ser um efetivo e transgressor elemento de (de)formação de identidades outras, distantes da norma e do regramento próprios de uma cultura heterossexual e machista, apontando para o queering identitário. Noutras palavras, de forma paralela ao exercício de construção identitária que promove, favorecendo a criação de um ethos para si mesmo, o cânone literário pode, também, ser "lido a contrapelo" de forma a nos possibilitar a apreensão de discursos e formas não normatizadas e não normalizadas a partir dos textos literários que o compõem.

De fato, toda a vez que aludimos a existência de um "cânone" - seja ele qual for e compreendendo quaisquer matizes - falamos necessariamente num duplo movimento: inicialmente, trata-se de um processo de escolha e seleção efetivado por leitores cujo gesto de leitura e cuja posição social/ ideológica/política/cultural lhes permite interferir ou, senão, determinar que obras podem ou não pertencer a esta lista de “eleitas”. Nesse procedimento, a eleição daquilo que pertence ao cânone corresponde, ainda, a um conjunto de "regras" que tendem a facilitar a seleção ou a, pelo menos, favorecer a construção de um edifício estético com horizontes prédeterminados e que visam a conformação de discursos tais como o da 
nacionalidade. A segunda laçada dirá respeito ao fato de que o cânone é ideologicamente prescritivo, uma vez que determina o que deve e o que pode ser lido, bem como se erige tendo como bases não apenas valores estéticos e artísticos, mas também outros valores que subjazem ao tecido social e cultural de qualquer povo. Poderíamos, ainda, pensar que se trata de um procedimento que visaria eleger aqueles textos que de alguma forma reforçariam valores ou ideais, em situação correlata ao que acontece aos textos bíblicos, de onde, aliás, a literatura toma a noção de cânone por empréstimo. Se tomarmos a questão por este ponto de partida, o cânone se justificaria, como a bíblia, pela prescrição de obras que favoreceriam a formação dos indivíduos, proporcionando-lhes uma espécie de resistência tanto a discursos que não conformariam o panorama estético aduzido pelo cânone, como também reforçaria a ideia de que os textos que o compõe carregariam os valores necessários à construção moral e cultural desses mesmos indivíduos.

Redunda desses dois processos o jogo de exclusões atinentes à formação canônica, uma vez que não lhe pertencer significa, em muitos casos, o esquecimento de certas obras no correr da história e a dificuldade de construírem ou negociarem sentidos com o concerto cultural do qual estão excluídas. Ou seja, se tomarmos o cânone literário brasileiro, no qual percebemos a ausência tácita de mulheres, indígenas e negros, vemos que o período de sua formação - o século XIX - excluía do acerto cultural justamente aquelas figuras marcadas pela diferença e que não carregariam, de fato, valores sociais e culturais que reforçassem a construção de uma "nacionalidade", qual a defendida por aquele cânone que se formava. Da mesma forma, o cânone que se formaria naquela altura refletiria os procedimentos e processos de subalternização aos quais aqueles atores sociais estavam submetidos.

O ponto de fuga do próprio cânone é que ele, algumas vezes, elege e inclui em si formas e discursos que destoam do arranjo que ele mesmo defende, como é o caso, na lírica medieval galego-portuguesa, das Cantigas de Escárnio e Maldizer. Se por um lado tais cantigas, cujo tom satírico 
apontaria para certo reforço dos presumíveis valores culturais e morais da época em que circularam, por outro denotam estética e socialmente a existência de formas de comportamento e expressão que destoavam da tônica cristianizada própria da Idade Média europeia e mesmo da tópica amorosa, como o vemos nas Cantigas de Amor e Amigo. Funcionando como um canto paralelo à norma, as cantigas satíricas vinham dar conta, de certa maneira, à inflexão cultural que determinava o que poderia e deveria ser dito, bem como quem e o que poderia ser literariamente representado na forma lírica dessa poesia, dando, no campo poético, vazão às outras e diversas experiências, que não as apenas ligadas a um ideal sublime de amor. Ao decantarem o sexo, o profano, o erótico e ao lançarem mão da linguagem comum e cotidiana, sem retoques metafóricos, faziam do jocoso um instrumento que deformava a ordem, bem como instaurava a possibilidade de se fazer representar práticas impedidas de circularem em textos de carácter amoroso, como o é, de fato, a representação que vemos a seguir, na Cantiga de Afonso Anes de Cotom:

\author{
Marinha, ende folegares \\ tenh'eu por desaguisado; \\ e som mui maravilhado \\ de ti, por nom rebentares: \\ ca che tapo eu [d]aquesta minha \\ boca a ta boca, Marinha; \\ e destes narizes meus \\ tapo eu, Marinha, os teus; \\ e das [mias]mãos as orelhas, \\ os olhos, das sobrencelhas; \\ tapo-t’ao primeiro sono \\ da mia pissa o teu cono, \\ e mi o nom veja nengum,
}


e dos colhões [esse] cũ,

como nom rebentas Marinha!

Observemos que o enunciador indiretamente alude às capacidades corpóreas e sexuais de próprias e da amante, visto que, ao dar relevo ao fato de Marinha não "rebentar” - ou seja, não se sentir machucada com as "cobridas", 3 tapadas, do amante - enaltece não sua mestria amorosa, gesto próprio da lírica amorosa medieva -, mas a sua potencia sexual associada à disposição daquela mulher para todo o tipo de coito. Aliás, embora seja o enunciador aquele que fala sobre o ato sexual, indiretamente vemos que esta mulher, embora silenciada textualmente, discursiviza-se na vivência plena de um corpo que sente, goza, vibra e que leva o eu poemático a repetir "como nom rebentas Marinhas", ora em tom de dúvida, ora de admiração. Esse corpo que não fala no poema, parece "folgar" (alegrar-se, comprazer-se), em lugar da lutuosa dor de amor que vemos representada em tantas outras cantigas e que, de fato, apaga o corpo feminino ao restringi-lo a apenas algo cujo sentido só se enseja na presença (e na saudade) do amado. Isto sem contar nos múltiplos usos sexuais prazerosos a que este corpo feminino parece se propor, a ponto de deixar o enunciador "desaguisado" (sem guia, sem rumo) e "maravilhado" com a destreza sexual de Marinha, a que se complementa, ainda, à mestria sexual e amorosa do próprio trovador. A figura encarecida na cantiga, Marinha, provavelmente

2 "Marinha, o teu folgar /tenho eu por desacertado,/e ando maravilhado /de te não ver rebentar;/pois tapo com esta minha /boca, a tua boca, Marinha;/e com este nariz meu,/tapo eu, Marinha, o teu;/com as mãos tapo as orelhas,/os olhos e as sobrancelhas,/tapo-te ao primeiro sono;/com a minha piça o teu cono;/e como o não faz nenhum,/com os colhões te tapo o cu./E não rebentas, Marinha?". Versão de Massaud Moisés. A versão original em galego-português está registrada no Cancioneiro da Biblioteca Nacional (Portugal) sob o número 1617. Disponível para consulta em <http://cantigas.fcsh.unl.pt/cantiga.asp?cdcan$t=1643 \& p v=\operatorname{sim}>$. Acesso em: 15 fev. 2016.

3 Forma popular encontrada em diversos povos falantes da língua portuguesa e que indica, metonimicamente, o ato sexual. Seu uso mais corriqueiro diz respeito, entretanto, ao ato reprodutivo dos animais de criação extensiva. 
teria sido uma soldadeira, ou seja, uma mulher que acompanhava os regimentos militares medievais, oferecendo-lhes seus serviços domésticos, inclusive os sexuais, sendo, portanto, uma imagem feminina a que era permitido o uso de seu corpo. Notemos, apenas, que este uso, segundo o trovador, é um uso pleno, uma vez que o "folegar" (folgar) de Marinha denotaria uma posição feminina não passiva diante do uso comercial feito de seu corpo, o que no caso, para ela, ultrapassaria o utilitarismo próprio da prostituição pela indicação do seu prazer no intercurso sexual.

Sexual, não amorosa! E eis aqui um signo da deformação a que antes aludi: obliterados pela representação do amor cortês, bem como por sua ideação romântica, outras formas poéticas como o maldizer, o escárnio e mesmo as cantigas de amigo encerram a materialização de vivências que corrompem o imaginário acerca da Idade Média, uma vez que demonstram a um leitor empírico que nem só de amores sublimados viviam os seres àquela altura, mas também de toda a sorte de fetiches e vivências ainda hoje consideradas transgressivas, como o prazer anal, por exemplo. O leitor, no caso, vê deformada a (sua) visão canônica que fizera preponderar um imaginário medieval em que o corpo inexiste e com isso, também, o sexo, o prazer e o gozo. Ao lado desse pormenor, outro que gera interesse: a cantiga sugere uma identidade feminina que parece distante da visada subserviente mormente atribuída à mulher medieval: ainda que se trate de um recorte muito específico dessa identidade, a cantiga revela, pois, o desejo feminino como elemento de transgressão, já que ela, Marinha, "folga" nesse jogo de corpos, mãos e órgãos sexuais tanto quanto o próprio enunciador, o que em si pode nos indicar a rasura a um comportamento que pelo senso comum fazia equivaler prática social, moral e sexual. Trocando em miúdos: ainda que a identidade feminina representada na literatura medieval seja trilhada no silenciamento ou na "terceirização" de sua voz pela voz masculina, a cantiga faz parecer que as vivências do corpo pudessem talvez não corresponder a este silenciamento. Se a voz cala, o corpo fala, como bem já o pudemos perceber nas diversas cantigas 
em que a filha engana os cuidados da mãe para manter encontros amorosos com seu amado.

Seguindo a mesma linha da subversão às práticas sociais, amorosas e sexuais, o soneto de Manuel Barbosa du Bocage a seguir, bem poderia apontar para certa licenciosidade nos prazeres ou, ainda, talvez, para certas alternativas ao ideário de pureza e castidade defendidos socialmente há até bem pouco tempo:

Que eu não possa ajuntar como o Quintela

É coisa que me aflige o pensamento;

Desinquieta a porra quer sustento,

E a pívia trata já de bagatela.

Si n'outro tempo houve alguma bela

Que o amor só desse o cono pennugento,

Isso foi, já não é; que o mais sebento

Cagaçal quer durázia caravela.

Perdem saúde, bolsa, e economia;

Nunca mais me verão meu membro roto;

Está aí minha porral filosofia.

Putas, adeus! Não sou vosso devoto;

Co'um sesso enganarei a fantasia,

Numa escada enrabando um bom garoto.

(BOCAGE, 2003, p. 77)

No soneto de Bocage, dois aspectos parecem destoar: primeiro, o uso da forma poética soneto, cujo conteúdo normalmente versa sobre o aspecto sublime dos afetos e das emoções e, o segundo, decorrente disso, é seu uso satírico, o que destoa do conteúdo típico que nele vemos. Valendo-se de uma estrutura literariamente rígida, o poeta “ousa” lançar mão dela para 
versar sobre algo considerado grotesco, baixo e, até mesmo antinatural. A despeito daquilo que hoje seria considerado altamente transgressivo, abusivo e desrespeitoso - a pedofilia --, a voz que fala no poema encara sua atitude como uma alternativa ao fato de "alguma bela" puta àquela altura querer uma "durázia caravela” em lugar de oferecer-lhe o seu "cono penugento". A permissividade sexual, a parafilia, ganha seu contorno com o fato de o enunciador enganar a própria fantasia preferindo o ato escuso de ter prazer com um rapazinho a ver-se devotado ao ato sexual pago, seja ele como for, com uma prostituta, dando a entender ou que conseguisse sexo gratuito com jovens rapazes ou, ainda, que para a obtenção de seu próprio prazer não interessasse o gênero de sua parceria: “[...] é curta a idade, / E as horas do prazer voam ligeiras!”. (BOCAGE, 2003, p. 8I)

Ato sexual e forma poética, nesse caso, parecem se corresponder, uma vez que o considerado "natural" para um homem, àquela altura, seria de fato de desejar uma mulher e não um outro homem, ainda que mais jovem. Se considerarmos aqui a relação entre forma poética e formato sexual, o soneto revelaria a possibilidade de uma dupla subversão, já que esta forma poética não corresponderia ao que dela se esperava nem o ato sexual ali descrito, ao "usualmente" praticado. Da mesma maneira, ao aludir à prática de caráter sodomita, bem como ao ato pederástico (o sexo entre um homem mais velho, com barba, e outro impúbere), o poeta transgrediria ao sexualmente e eroticamente esperado para sua época, mas vincularia sua prática erótico-sexual ao momento de produção de sua obra, ou seja, a segunda metade do século XVII português. Lembro: tal período artístico valorizara o retorno aos temas e formas da antiguidade clássica, sobretudo a helênica e ao lançar mão do ato pederástico - valorado como forma educacional na antiguidade grega - o poeta fizera menção aos elementos estéticos valorizados àquela altura, apenas que se valendo, não da exposição de desejos "usuais", mas de uma prática social e cultural paralela à altura da escrita do poema e vivenciada naquela mesma antiguidade que o inspirara em outros poemas. 
Ou seja, reafirmando o modelo canônico e o aparente padrão cultural de sua época, o poeta usá-lo-á para expor poeticamente uma prática fora do padrão ou talvez discursivamente silenciada, mas talvez existente como subterfúgio, alternativa à preservação moral das relações mantidas entre homens e mulheres. Ao potencializar o valor estético seu contemporâneo, o poeta propõe fazê-lo transgressivamente, ato que se repetirá em inúmeros outros sonetos e poemas, nos quais o aspecto sublime da linguagem é substituído pelo uso supostamente grotesco, mas que a vincula ao real mais imediato daqueles seus possíveis leitores/fluidores. Essa intervenção no campo da expressão e da linguagem, que de fato não é um procedimento corriqueiro se considerado o todo poético de Bocage talvez não se trate apenas de uma tentativa de aproximar texto e leitor, mas, antes, de operar no poema uma naturalização que na verdade - e pela transposição dos campos do interdito e do ofensivo - apontaria para uma espécie de queering expressivo, no sentido em que ressignificaria tais termos ("cono", "cagaçal”, "porral”), reintroduzindo-os agora no campo esteticizado do poema e de maneira também esteticizada, fazendo do tosco e do grotesco, um expressão do sublime.

A linguagem, aliás, no seu uso performativo - na sua capacidade de criar, produzir e vivificar aquilo que nomeia - pode ser entendida como um procedimento queer, ao mesmo tempo em que, por outro lado, negativamente pode demarcar a normatividade que cerceia as noções de gênero. No caso, o gesto queer em questão estaria no fato de ao mesmo tempo em que o enunciador poemático potencializa seu impulso erótico-sexual e desnaturaliza o desejo ao demonstrar que para quem está excitado, pouco importaria o objeto, mas o exercício do “tesão". Por outro lado, este mesmo plano da expressão funcionaria negativamente, valorando "normas de gênero [que] operam ao ordenar a corporificação de certos ideais de feminilidade e masculinidade, ideais que são quase sempre relacionados à idealização do vínculo heterossexual” (BUTLER, 2003, p. 157), coisa que de fato acontece, posto que seja com uma puta ou com um garoto, mesmos permanecem desejo, gênero sexual e identidade masculina desse 
enunciador, todos eles intocados e como indiretamente afirmará em outro soneto: "Para que nos deu Deus porras leiteiras, / Senão para foder com liberdade?" (BOCAGE, 2003, p. 8I).

Aspecto que também parece ter relevo tanto na cantiga trovadoresca da Enes Cotom quanto nos sonetos de Bocage diz respeito aos tênues limites entre dois rótulos, aos que prefiro chamar "etiquetas culturais" ou "modos de ler": a nebulosa fronteira entre o erótico, o obsceno e o pornográfico. Susan Sontag (1987, p. 44-45) declarara em seu $A$ imaginação pornográfica que "é mais plausível apenas enfatizar que a pornografia ainda possui somente uma 'intenção', ao passo que a obra de literatura de real valor contém muitas", já que "o propósito da pornografia é inspirar uma série de fantasias não-verbais em que a linguagem desempenha um papel secundário, meramente instrumental”. Noutras palavras, o que a filósofa pareceu aludir diz respeito ao fato de que a pornografia tiraria o "valor" estético da linguagem literária (e de qualquer outra obra assim "rotulada”), já que tiraria os seus possíveis sentidos do campo da produção de significados, localizando-os no eixo, apenas, do significante. E nesse caso, o significante redundaria vazio, já que não seria capaz de fomentar as múltiplas flutuações próprias de um texto e que redundam da sua inserção na cultura. Cabe, claro, esclarecer que no caso da cantiga e do poema aqui lidos, os poetas pareceram optar por resvalar e transpor os limites entre o que parece permitido ao literário (o uso erótico da linguagem) e àquilo que lhe caracteriza - o uso apurado e intencional dessa mesma linguagem -, deslendo os códigos culturais e sociais próprios da época de circulação de suas obras. Essa desleitura do cânone por ele mesmo pode apontar para uma transgressão da linguagem literária, de forma a lembrar aos seus possíveis ouvintes/leitores/fruidores de que no mesmo campo onde o subjentendido e o jocoso operam, naquele mesmo onde o erótico se perfaz na linguagem, aquilo que está fora de cena - o obsceno, portanto - e que transgride a ordem pela naturalização do grotesco - o pornográfico retornaria aos poemas, agora, como forma e força estética, queerinzando a linguagem e a tornando queerente com o conteúdo semântico que veicula. 
Traduzindo: o sublime, o formativo, o assento nos aspectos valorativos e que poderiam contribuir para a construção de um ethos, surgiriam não apenas daquela literatura elevada, mas também redundariam da desleitura do sublime pelo grostesco e na instauração de outro sublime, nascido ali mesmo onde a linguagem poética optou pelo uso do chulo ou do que não caberia no poema, inclusos ali os corpos nele representados.

Seria muito propormos uma desleitura desse cânone moralmente formador, leitura indicada para a formação de cidadãs e cidadãos apenas considerando aqueles aspectos que denotariam o transgressivo do cânone ou um cânone transgressivo e que fosse apenas baseado na leitura de textos pertencentes a este mesmo cânone e considerados, ainda assim, satíricos, obscenos e jocosos. Entretanto, vale nos reportarmos aos modernismos português e brasileiro, tão afeitos às reformas dos padrões estéticos, mas moralmente inscritos, ainda, aos formatos de comportamento que pouco tinham de reformistas ou de vanguarda.

Investindo na temática do duplo, cara à literatura dos fins do século XIX e mesmo à sua Geração de Orpheu, Fernando Pessoa (I888-I935) no poema "Eros e Psique", o poeta modernista português, ao reafirmar uma tônica de sua poética, também impõe uma curiosidade aos seus leitores: no poema, a princesa que dorme é também o príncipe que a vai acordar. Podemos deduzir num primeiro momento que se trata, na economia da obra pessoana, de um gérmen da questão heteronímica, apenas que lançando mão dessa duplicidade pela introdução, no poema, de figuras que se espelham e que derivam entre ser eu e ser outro, ao mesmo tempo. ${ }^{4}$ Entretanto, há de ser observar que esse espelhamento se traduz na diversidade entre os gêneros sexuais e identitários entre as duas figuras que habitam o poema, o que redundaria, inclusive, na distinção entre esses dois corpos:

${ }^{4}$ Por heteronímia (do grego, "outro nome") entende-se o procedimento estético que consiste em criar personalidades poéticas diferentes da instância autoral e com características estéticas distintas entre si, ou seja, um outro do próprio autor. Cf. MARTINS, Fernando Cabral (org.). Dicionário de Fernando Pessoa e do Modernismo Português. São Paulo: Leya, 2010. p. 326-333. 


\section{"EROS E PSIQUE"}

Conta a lenda que dormia

Uma Princesa encantada

A quem só despertaria

Um Infante, que viria

De além do muro da estrada.

Ele tinha que, tentado,

Vencer o mal e o bem,

Antes que, já libertado,

Deixasse o caminho errado

Por o que à Princesa vem.

A Princesa Adormecida,

Se espera, dormindo espera,

Sonha em morte a sua vida,

E orna-lhe a fronte esquecida,

Verde, uma grinalda de hera.

Longe o Infante, esforçado,

Sem saber que intuito tem,

Rompe o caminho fadado,

Ele dela é ignorado,

Ela para ele é ninguém.

Mas cada um cumpre o Destino

Ela dormindo encantada,

Ele buscando-a sem tino

Pelo processo divino

Que faz existir a estrada. 
E, se bem que seja obscuro

Tudo pela estrada fora,

E falso, ele vem seguro,

E vencendo estrada e muro,

Chega onde em sono ela mora.

$\frac{192}{c m}$

E, inda tonto do que houvera,

À cabeça, em maresia,

Ergue a mão, e encontra hera,

Evê que ele mesmo era

A Princesa que dormia.

(PESSOA, I977, p. I8I)

Observemos num primeiro momento o processo de diálogo intertextual entre o conto tradicional "A bela adormecida”, apenas que agora com seu desfecho deslocado do tradicional "e foram felizes para sempre”, que redundaria num encontro com o outro, para o encontro com uma outra identidade, descentrada tanto do corpo como da própria subjetividade. Ao mesmo tempo, o poeta dialoga com o mito grego que se refere à conflituosa paixão entre Eros/Cupido (o Desejo) e a bela Psique, cujo fruto final será o nascimento da filha Hédone (o Prazer). As leituras mais contumazes apontariam para uma alegoria relativa à personificação da alma, aspecto metafísico relacionado a uma natureza feminina, envolvida entre as várias vicissitudes da existência, o sofrimento, o amor. Por outro lado, a incomum epígrafe do poema parece favorecer a um outro caminho:

E assim vêdes, meu Irmão, que as verdades que vos foram dadas no Grau de Neófito, e aquelas que vos foram dadas no Grau de Adepto Menor, são, ainda que opostas, a mesma verdade. (Do Ritual Do Grau De Mestre Do Átrio Na Ordem Templária De Portugal). (PESSOA, 1977, p. 18I) 
Que verdades seriam estas a serem "reveladas", que mesmo sendo opostas, são as mesmas e que são dependentes, inclusive, do grau de iniciação do indivíduo dentro de uma ordem como a dos templários? A epígrafe, como uma chave para um possível sentido do poema, parece apontar, justamente para a cisão/fusão do par falsamente opositivo masculino/ feminino: a verdade primeira (ser príncipe) corresponderia à outra (ser princesa), aparentemente opostas, mas, de fato, complementares. Numa palavra e dialogando com o próprio Pessoa quando "declara” ter "um temperamento feminino com uma inteligência masculina” (PESSOA, I990, p. 40), nada mais faria o príncipe do poema que sair em busca dessa princesa que dorme dentro de si mesmo, ou seja: a inteligência masculina revelaria, necessariamente, aquele temperamento feminino adormecido pelas diversas injunções sociais e culturais das primeiras décadas do século XX. E justo neste ponto tanto o apelo ao uso do duplo quanto a questão heteronímica parecem se laçar: a grande descoberta do Outro ("ele dela ignorado") em si mesmo talvez não passasse de fazer despertar em si, na verdade, uma Outra, princesa adormecida em suposta fragilidade silenciada ("ela para ele é ninguém") e que se impõe como urgência e destino do "Infante, esforçado". Longe, portanto, de alguma misoginia atribuída aos participantes de Orpheu (1915), Pessoa poderia querer enfatizar essas possibilidades de ser, inclusive, deixando claro a existência dentro de si de um duplo supostamente oposto, mas complementar, que se poria numa perspectiva supragênero. Mais uma vez aqui, "num vago masoquismo" (PESSOA, 1990, p. 40), que é a própria busca do amor da princesa (a linguagem) pelo príncipe (o corpo e o poeta), ou seja, a busca de si mesmo(a), o poeta rasuraria multiplamente a tradição: recomporia o sentido do mito grego; do conto tradicional e, na sequência, desfaria as antinomias culturais e sociais que oporiam os gêneros sexuais e identitários, apontando, ainda que sutilmente, para a existência de uma identidade queer que precisaria ser respeitada na sua particularidade: "é uma inversão sexual fruste” (PESSOA, I990, p. 40), só realizável no poema, ou seja, na 
linguagem, único lugar possível, àquela altura, em que se poderia efetivamente viver o corpo e não ser.

O poema "Eros e Psique" seria, de certa forma, um duplo metapoema, uma vez que reproduz a criação e o encontro deste(a) Outro(a) e de sua alteridade, ao mesmo tempo em que funciona como uma blague modernista, talvez um ponto de partida de uma certa tendência da literatura portuguesa de tematizar as questões que tangenciem às experiências de gênero e sexualidade, como se pode ver na contemporânea de Pessoa, Judith Teixeira, poeta portuguesa sequestrada do cânone, lésbica assumida:

$[\cdots]$

És linda assim: toda nua,

No minuto doce

Em que me trazes

A clara oferta do teu corpo

E reclamas firmemente

A minha posse...!

$[\cdots]$

Loira Salomé

De ritmos esculturais!

Vem mais nua

Esta madrugada!

Vem esconder-te na sombra dos meus olhos

E não queiras deixar-me...

Ai nunca, nunca mais!

(TEIXEIRA, 1996, p. 216)

Se em Fernando Pessoa vemos um corpo algo esvaziado de sua função erótica - e mesmo de seus afetos - sua contemporânea Judith parece 
perceber que diante de um panorama cultural e literário modernista, seria preciso demarcar também na expressão de corpos e dos silenciados e/ou obliterados uma posição que apontasse, naquele contexto, um procedimento de vanguarda: há uma certa performatividade do corpo e do gênero representada pela poesia de Teixeira, o que, para a sua época, tratava-se de uma experimentação e de um descompromisso com o atendimento à demanda particular de uma literatura de e para mulheres, que, claro, à altura denotava, ainda, um corpo aprisionado. $\mathrm{O}$ corpo que se expressa na poesia de Judith Teixeira, como o/os corpos de António Botto e os de Raul Leal - contemporâneos seus, experimentam e experienciam (insisto nas formas variadas de uma ação semelhante e entre semelhantes) seus desejos, afetos e impulsos e revelam a presentificação intensa da linguagem pela ação de um sujeito que a suporta. Nesse sentido, a construção do poema em Judith parece nascer da "friç̧ão" entre o excessivamente estético e o excessivamente comum, corriqueiro, mas elevado, que é o desejo; ou mais: uma fricção entre o seu corpo e o corpo de uma Outra, Salomé.

O modernismo português de certa forma deu aos seus artistas a opção entre despir e desnudar ou de encobrir e aprofundar certos "detalhes", como vemos no contraste entre Judith e Pessoa. No caso brasileiro, uma suposta desconformidade do corpo - plasticamente bem posta no Abaporu de Tarsila do Amaral - pareceu rondar boa parte de uma literatura produzida sob o signo da modernidade paulista: a tela da artista, ao potencializar os disformes pés da figura ali representada, encena o gesto metonímico que se vê, por exemplo, também, em Mário de Andrade no poema "Girassol da Madrugada". Um corpo estranhamente metonímico, cujo gênero identitário e sexual nunca aparece demarcado, a não ser pelos detalhes mais amplos, que o notabilizam apenas no campo do afeto e das sensações, mas jamais no espaço de um prazer que se possa ser, de fato, vivido. Esse "vazio" na representação do outro talvez encontre azo na disponibilização, pela Fundação Casa de Rui Barbosa, de uma carta trocada entre Mário de Andrade e Manuel Bandeira, onde o primeiro comenta sua "tão falada" homossexualidade: embora consiga transpor o 
modelo estético europeu em favor de uma dicção poética brasileira, Mário esbarraria, ainda, na dissociação entre prática estética e prática social, o que redunda, por exemplo, na constante interdição discursiva observada em alguns textos de sua autoria, como "Frederico Paciência". Diferentemente do que se viu em outros movimentos vanguardistas, inclusive latino-americanos, tanto o modernismo português quanto o brasileiro não viram razão entre associar estética e existência e nem em esteticizar a existência do artista. No caso, reitero, uma produção modernista ou vanguardista não corresponderia a um comportamento social e cultural de mesmos níveis e talvez decorra daí tanto a diluição de certos aspectos ligados às vivências do corpo, como também a sua metonimização: um corpo que é sempre recorte, recortado de seu gênero, de seus prazeres e de sua materialidade.

Muitas foram as leituras feitas do quinto entrecho do poema "Girassol da Madrugada”, cujos versos abaixo destaco. Entretanto, interessa a este ensaio, cujo foco, lembro, é o contraste entre as formas de representação canônica e os pontos de fuga neste e deste mesmo cânone, pôr em relevo a esta altura a desleitura proposta pelo próprio poema:

V.

Teu dedo curioso me segue lento no rosto

Os sulcos, as sombras machucadas por onde a vida passou.

Que silêncio, prenda minha... Que desvio triunfal da verdade,

Que círculos vagarosos na lagoa em que uma asa gratuita roçou...

Tive quatro amores eternos...

O primeiro era uma donzela,

O segundo... eclipse, boi que fala, cataclisma,

$\mathrm{O}$ terceiro era a rica senhora,

O quarto és tu... E eu afinal me repousei dos meus cuidados.

$[\cdots]$

(ANDRADE, I987, p. 339-34I) 
O título do poema já nos impõe uma quebra de paradigma, visto que um girassol, como indicado no próprio nome, seria uma flor cujo sentido não se perfaria na madrugada. Entretanto, se contrapusermos a existência da flor ao momento do dia em que ele é retratado, podemos inferir na construção de uma possibilidade: o girassol poematizado não poderia se não existir durante a madrugada, período em que a pouca ou inexistente luz traria a oportunidade de experimentar, inclusive, as coisas impossibilitadas, dando-lhes outro sentido, uma vez que o poema, resumindo a "perversa e imaculada correria dos fatos" declara que "De dia não seremos nada”, enfatizando a existência de uma relação apenas possível no sombreamento noturno. Na sequência, a instância que fala no poema passa a descrever o tempo vivido e os amores marcados na vida, agora olhados na maturidade e que perfazem uma relação estranha entre o tempo passado ("tive") e a sua permanência ("eternos"). Dentre os quatro amores descritos, o segundo assume-se como um interdito, um sombreamento na linguagem, posto que descrito como "eclipse, boi que fala, cataclisma": um amor que se aclara pela ausência solar, denotando-se na ordem do impossível e numa consequente transformação baseada num acontecimento arrasador, que modifica os padrões de percepção e marca a finitude de algo.

Por último, a caracterização de um "tu" onde "eu afinal me repousei dos meus cuidados" e de uma "eu" que se desprende de certos impedimentos e que se dispõe a viver seu afeto. Em nenhum momento do texto observamos alguma marca de gênero relacionada àquele "tu", o que pode resultar na naturalização baseada em toda a tradicional e sedimentada lírica amorosa romântica: se não há uma marca identitária, esse amor se devotaria a uma mulher. Entretanto, lendo o poema por outra clave e considerando ainda os níveis de sombreamento e interdição, a intencionalidade dessa caracterização obscura talvez redunde não no desenho de um amor heterossexual impossível, mas, justo, noutra possibilidade: não se poder dizer o nome do amor homossexual vivenciado pelo enunciador e disso decorreria o esvaziamento identitário a que tanto quem se enuncia quanto a "instância” a quem se dedica o poema estão submetidos. Ao lado disso, o "eu” que 
"narra” a existência desse girassol - signo masculino, aliás - também não se desenha na linguagem, sendo tanto ou mais vazio que o seu objeto amoroso. Se consideramos que girassol não é um elemento usual nos discursos amorosos, poderíamos, sem muito esforço, relacioná-lo ainda a uma marca de gênero masculino, visto que muito menos usual é usar uma rosa ou uma azaleia para descrever um homem em contexto amoroso. $\mathrm{O}$ poema ganharia, ainda, um relevo mais tenso quando imaginamos que a língua considera o grau zero, o vazio, a forma não marcada, o masculino e o singular, ou seja, enunciador e enunciado estão ambos relacionados à mesma experiência em termos de gênero e identidade - são ambos seres do sexo masculino - afirmação nada forçosa se consideramos os padrões da própria linguagem. Os vazios identitários, os obscurecimentos, os sombreamentos discursivos do poema nesse caso, apontariam a necessidade de diluir o canto amoroso diante de um possível leitor que - por uma série de questões sociais e morais - diminuiria o valor estético do poema caso ele explicitamente estivesse tematizando e se enunciando no masculino. O poeta, assim, conta com a naturalização da leitura e com a convenção social - "todo poema de amor é dedicado a uma mulher" - para, a partir dessas mesmas convenções e também as da linguagem, cantar seu amor pelo "pueril [...] olhar" de um rapaz. Numa palavra: parte-se das formas mais canônicas para se propor enunciações e atos de fala nada canônicos, contando-se, para isso, com as diversas naturalizações a que a literatura, como objeto da cultura, é submetida quando se trata de gêneros, identidades e de qualquer outro fenômeno ligado às sexualidades.

Retorno ao título e ao início desse ensaio. Para tanto, penso com Antonio Candido no seu artigo "Direito à literatura", que sendo a literatura algo atinente à condição humana, seja necessário pontuar em si as especificidades identitárias que caracterizam o humano. Nesse sentido, creio que a literatura, enquanto elemento de formação humana e como sedimento cultural deva dar direito à expressão do diferente, da diferença e à representação da diferença. Sobretudo porque, de maneira subliminar, essa diferença já conviva intrinsecamente silenciada no cânone ou sendo 
por ele tratada como uma questão menor e que não represente de maneira intensa as intencionalidades de uma cultura e de uma época. Mesmo que ainda sabendo que "Nem toda a gente gosta do diferente", como dirá Ana Luísa Amaral, e que textos como os lidos aqui podem contribuir a deformação dos leitores, cabe lembrar que como manancial, a literatura já esteve a diversos serviços, mas ainda não ao serviço da efetivo da diversidade.

\section{Referências}

AMARAL, A. L. Como tu. Vila do Conde/Portugal: QuidNovi, 2012.

ANDRADE, M. Poesias completas. Belo Horizonte: Itatiaia; São Paulo: EdUSP, I987.

BOCAGE, M. M. B. du. Poesia erótica. Lisboa: Dom Quixote, 2003.

BUTLER, J. “Critically Queer”. In: STRIFF, E. (Org.). Performance Studies. New York: Palgrave, 2003. p. 152-177.

CANDIDO, A. A Literatura e a formação do homem. In: CANDIDO, A. Remate de males. Campinas: Unicamp, 1999. Disponivel em: <http://revistas.iel. unicamp.br/index.php/remate/article/viewFile/3560/3007>. Acesso em: I2 fev. 2016.

JOUVE, V. Por que estudar literatura?. São Paulo: Parábola, 2012.

MARTINS, F. C. (Org.). Dicionário de Fernando Pessoa e do Modernismo Português. São Paulo: Leya, 2010. p. 326-333.

PESSOA, F. Obra poética. Rio de Janeiro: Nova Aguilar, 1977.

PESSOA, F. Obra em prosa. Rio de Janeiro: Nova Aguilar, 1990.

SONTAG, S. A vontade radical - estilos. São Paulo: Cia das Letras, 1987.

TEIXEIRA, J. Poemas. Lisboa: \& Etc, 1996. 


\title{
A literatura e as constelações familiares: \\ como instaurar outros \\ "melhores mundos possíveis"
}

\author{
渵 \\ Renata Pimentel
}

\section{Reconhecendo o terreno}

Tão logo um indivíduo trava contato com uma obra de arte, mundos se põem em relação: por vezes de estranhamento, de reconhecimento ou até de confronto. Mas o que faz um leitor, quando põe a máquina literária a funcionar? Torna-se, ele próprio, um dos construtores dos mundos "possíveis" e imaginados que lhe são apresentados. Nem sempre, porém, recebe pacificamente ou identifica-se com os ingredientes deste universo. Como diz Renato Cordeiro Gomes (I994, p. I5): “É arrastado, 
enquanto leitor, pelo movimento permutacional no mundo vicário dos signos. $\mathrm{O}$ jogo da circulação da linguagem se descentra e possibilita novas leituras". É instaurada uma espécie de jogo, no qual o leitor se converte em peça fundamental dos sentidos, como uma espécie de espião, flâneur, voyeur ou penetra. Ainda nas palavras de Renato Gomes (1994, p. 15), referindose a si próprio em sua experiência: “...constituo-me tal qual um eu à deriva, que, embora não solto no espaço e no tempo, inscreve-se no movimento da dança, entre o deslocar e o estatelar."

Mas é preciso estar atento: deslocamentos exigem escolhas e implicam surpresas. Por mais planejamento que se faça, o inesperado surge; e, mais ainda, se estamos situados neste particular terreno que é a arte, cujas relações são muito estreitas, diversas e imbricadas quanto aos mais variados planos da vida humana: espiritual, ética, moral, mundana, social, política, econômica. Para além de ser testemunho e legado cultural do ser humano, a obra de arte traz em si as idiossincrasias e contradições dos tempos e contextos em que foi criada e, por sua potência transtemporal, presentifica-se a cada nova recepção e passa a revelar também aspectos deste particular momento em que é "posta em funcionamento" pelo seu leitor/público.

Algumas manifestações artísticas, ainda, em seu caráter transtemporal e multifacetado como discurso/representação, valem como terreno de luta política e humana por direitos. As relações entre a produção literária e a ordem de valores (como já apontado) são inúmeras e multifacetadas: desde servindo a projetos de dominância quanto os questionando e propondo novos paradigmas. Mas certo conjunto de obras nessa linguagem artística, muitas vezes se vê reduzido ou diminuído em sua relevância, ao dissociar-se de concepções hegemônicas interessadas na manutenção da "moral dominante" - do status quo -, ou mesmo ao contrapor-se a estes valores. Precisamente neste último conjunto estão as obras que nos interessarão e ocuparão nossas reflexões.

Nosso enfoque recai sobre obras que recebem constantemente "adjetivações reducionistas” a estigmatizá-las (literatura gay/homossexual/lésbica). Esses rótulos parecem ser usados para depreciar e disfarçar a importância 
objetiva de uma produção artística que reflete sobre os interditos sociais, sobre olhares que revelam as "normas" e suas arbitrariedades. Se aqui vamos pensar a literatura e o modo como as configurações familiares (particularmente as homoparentais) nela aparecem, precisamos ter atentos os sentidos da "peça-leitor" que somos para fazer funcionar a engrenagem e perceber os tantos questionamentos gerados a partir desse universo ficcional.

Podemos e devemos lembrar que em épocas distintas as relações estabelecidas entre os artistas e o financiamento/status e a recepção de suas atividades se configuraram em bases diferentes, modificadas ao longo das transformações sociais e econômicas em cada tempo, lugar, povo, cultura. Tomemos um breve recorte a partir dos séculos XVII e XVIII, quando imperava o mecenato a eleger e sustentar os pintores, compositores, poetas. É relativamente fácil supor que boa parte desses criadores buscava agradar quem lhes financiava, mesmo quando enxergava mazelas e injustiças. Mesmo assim, havia artistas que se contrapunham ao código moral estabelecido e impunham reflexões incômodas. Mas tratava-se de outra ordem, o acesso às artes era restrito demais à corte. Com a Revolução Francesa e a tomada de poder pelos burgueses, começa o avanço avassalador do poder do capital, o império do mercado - iniciado já no sistema mercantil convertido em capitalismo - transforma a vida do artista que passa a precisar se estabelecer no mercado e comercializar sua obra de arte.

A literatura romântica produzida pelos burgueses no século XIX (tanto no contexto europeu, quanto no da colônia ultramarina, convenientemente "alçada a Reino Unido" ou, em seguida, transformada em império “independente") revela, então, o projeto político-econômico moralista da família, do casamento como um negócio que envolvia educar as mulheres para se manterem reprodutoras e guardiãs do lar, fiéis aos seus senhores/ maridos, pois a prole precisaria ser legítima, para garantir a condição de herdar os bens familiares. ${ }^{\text {I }}$

1 Embora haja a dominante literatura folhetinesca e os romances para educar o público-leitor feminino aos valores da fidelidade (como na obra de José de Alencar); há as irônicas 
Em sua História da sexualidade (volume I - A Vontade de saber), Michel Foucault (I997, p. 9-IO) principia pela retomada de parte do mesmo percurso aqui evocado, indicando-nos como herdeiros e ainda suscetíveis de submissão à era vitoriana²:

A sexualidade é, então, cuidadosamente encerrada. Muda-se para dentro de casa. A família conjugal a confisca. E absorve-a, inteiramente, na seriedade da função de reproduzir. [...] O casal, legítimo e procriador, dita a lei. Impõe-se como modelo, faz reinar a norma, detém a verdade [...] No espaço social, como no coração de cada moradia, um único lugar de sexualidade reconhecida, mas utilitário e fecundo: o quarto dos pais. Ao que sobra só resta encobrir-se.[...] E se o estéril insiste, e se mostra demasiadamente, vira anormal: receberá este status e deverá pagar as sanções.

O discurso sobre o sexo vai ganhando contornos e regras: há lugares em que ele é silenciado, mas em outros "o essencial é a multiplicação dos discursos sobre o sexo no próprio campo do exercício do poder". (FOUCAULT, I997, p. 22) Logo, por razões políticas, econômicas e até técnicas, o sexo entra na ordem do dia, literalmente, pois ele precisa ser vigiado, prescrito no funcionamento interessante à lógica das sociedades. A polícia, a medicina, a igreja e as leis vão gerir a vida e o sexo, para regular o estabelecido por estas instâncias de poder como sendo o "bem comum": taxa de natalidade e mortalidade; expectativa de vida; nascimentos legítimos e ilegítimos e diversos outros aspectos que vão se desdobrar (ao longo

exceções. Um exemplo interessante é a obra Memórias Póstumas de Brás Cubas, de Machado de Assis, publicada em 1881. Apesar de inserir-se na sociedade - ter sido amigo de Alencar e fundador da Academia Brasileira de Letras (ABL) -, Machado era um "pária" para aquela burguesia (mulato, gago, epilético, criado pela madrasta lavadeira). Cria em Cubas o personagem que ironiza o casamento burguês em todos os aspectos: tem uma amante prostituta (Marcela), vive uma inteira trajetória de fracassos, sua relação mais duradoura é um adultério e morre sem deixar descendentes.

2 A Era Vitoriana foi o período no qual a Rainha Vitória reinou sobre a Inglaterra, no século XIX, de junho de 1837 a janeiro de 1901. 
dos séculos XX e XXI) em índices de produtividade, IDH, qualidade de vida, potencial de consumo. Assim resume Foucault (1997, p. 37-38):

Toda esta atenção loquaz com que nos alvoroçamos em torno da sexualidade, há dois ou três séculos, não estaria ordenada em função de uma preocupação elementar: assegurar o povoamento, reproduzir a força de trabalho, reproduzir a forma das relações sociais; em suma, proporcionar uma sexualidade economicamente útil e politicamente conservadora?

Neste cenário, a relação matrimonial e o modelo de família burguesa heterossexual, formada pelo "casal legítimo, monogâmico, fértil", se converte em norma rígida. As instâncias reguladoras de poder se empenham em questionar, perseguir e condenar os "desvios": as sexualidades, os comportamentos ou desejos e as relações não férteis; não convencionais; consideradas "loucas, patológicas, pecadoras ou criminosas".

Introduzimos nesta discussão a voz do sociólogo francês Pierre Bourdieu. Destacamos sua afirmação sobre o homoerotismo como uma forma de sexualidade que se opõe às estruturas do poder, dos jogos de relação de dominação e, sobretudo, da diferença binária do sexo, porque é uma relação de livre troca igualitária, sem sobreposição de um ao outro:

No caso em que, como se dá nas relações homossexuais, a reciprocidade é possível, os laços entre a sexualidade e o poder se desvelam de maneira particularmente clara, e as posições e os papéis assumidos nas relações sexuais, ativos ou passivos principalmente, mostram-se indissociáveis das relações entre as condições sociais que determinam, ao mesmo tempo, sua possibilidade e sua significação. (BOURDIEU, I999, p.3I)

A homossexualidade parece esvaziar a relação de dominação a que ficou presa a oposição masculino/feminino, pois ela é um lugar de desvelamento/revelação de antagonismos institucionalizados, de relações de poder predeterminadas. É uma sexualidade de fronteiras ou sem fronteiras, que 
se desvincula da tradição (mesmo com ela diretamente se relacionando, claro), para instaurar outro modo de se relacionar na vida, diverso das estruturas orgânicas quando percebidas como puramente naturalizadas.

Estas ideias de Bourdieu ecoam a noção de Deleuze quanto à "posição marginal" da homossexualidade como aquela que instaura "o espaço para desconstrução" da identidade de sujeito e do encarceramento das relações de poder e dominância de gênero:

\begin{abstract}
É do fundo de um novo estilo que a homossexualidade produz hoje enunciados que não versam, e não devem versar sobre a própria homossexualidade. Caso se tratasse de dizer "todos os homens são bichas”, isso não é de interesse algum, é proposição nula que só diverte os débeis. Todavia, a posição marginal do homossexual torna possível e necessário que exista algo a ser dito sobre o que não é homossexualidade: "com os movimentos homossexuais, o conjunto dos problemas sexuais dos homens apareceu”. (DELEUZE, 2005, p. 353)
\end{abstract}

Portanto, o "personagem" - que segundo Foucault foi "inventado" no século XIX - "homossexual” começa a produzir e agenciar desejos e enunciados que pulverizam as fixações identitárias. Pode ser aqui lembrada e invocada a metáfora deleuziana do espaço liso, de onde surgem as subjetividades transgressoras. A nomeada homossexualidade se imiscui em espaços lisos e porosos e se afirma como uma alternativa possível de relacionamento(s) na contramão do estabelecido. Mas como se trata de transgressão, insurge nos espaços marginais: “[...] o afastamento geográfico, a procura de lugares diferentes, a inscrição em outros espaços é a condição de uma reconstrução de si.” (ERIBON, 2008, p. 303)

\title{
Minando de dentro: ou quando se evidencia o gênero como uma proliferação de epifanias.
}

Se retomarmos as ideias de Foucault, mais uma vez, quanto à biopolítica, como uma estratégia de controle dos corpos (sexo, gênero, desejo, práticas), fica claro o quanto é fundamental a este exercício de poder a fixação 
identitária como mecanismo de classificação e gerência sociopolítica e econômica, que se verte em todas as formas, inclusive tentando criar "valores culturais" que são meras traduções da moral que se quer manter vigente. A filósofa e professora espanhola Beatriz Preciado - cujo pensamento convidamos agora para esta discussão e acompanharemos mais detalhadamente em seus desdobramentos - avança a partir de sua leitura da biopolítica foucaultiana, ao pensar assim o sexo (o qual pode ser também substituído na sentença a seguir por "gênero"):

O sexo é uma tecnologia de dominação heterossexual que reduz o corpo a zonas erógenas em função de uma distribuição assimétrica de poder entre os gêneros (feminino/ masculino) [...].

A natureza humana é um efeito da tecnologia sexual que reproduz nos corpos, nos espaços e nos discursos a equação natureza = heterossexualidade. O sistema heterossexual é um dispositivo social de produção de feminilidade e masculinidade que opera por divisão e fragmentação do corpo: recorta órgãos e gera zonas de alta intensidade sensitiva e motriz (visual, tátil, olfativa...) que depois identifica como centros naturais e anatômicos da diferença sexual. (PRECIADO, 20I4, p. 25)

A identidade sexual, após se constatarem as armadilhas desta tecnologia biopolítica, pode ser claramente compreendida não como uma expressão "instintiva" e "natural" desta verdade "pré-discursiva" que se tenta atribuir à carne (aos genitais), mas sim como uma série de efeitos de inserção e reinserção das práticas, e das performances, do gênero no corpo 3 . Por isso, aqui, escolhemos permitir que a própria literatura - objeto no qual adentraremos mais para pensar como ele problematiza os enlaces (bomo)parentais - nos fornece uma nova imagem e expressão para melhor matizarmos o fluido universo das identidades (ou identificações) de gênero e sexo: a "epifania".

\footnotetext{
${ }^{3}$ Aqui ecoam ainda as ideias de Preciado (cf. 2014, p. 29).
} 
Etimologicamente, trata-se de uma palavra de origem grega epiphainein e significa manifestação ou aparição. A raiz da palavra (phainein) pode ser traduzida como mostrar, fazer ou aparecer. É um vocábulo muito usado em sentido religioso, como sinônimo de uma manifestação divina. No caso da literatura brasileira, em particular, é impossível desassociar o termo epifania da escritura de Clarice Lispector, que fez deste um verdadeiro momento-chave desencadeador de seu universo diegético. Assim, propomos pensar o gênero e o sexo como verdadeiras epifanias do humano: momentos de revelação, de manifestação e revelação que engendram grande carga significativa, mas não cristalizam e podem se suceder ao longo da vida.

O primeiro fragmento literário destacado por nós foi extraído justamente da irmã de Clarice. No romance No exílio, no qual ficcionaliza a experiência de sua família na fuga ao nazismo (na diáspora judaica), atravessando países até fixar-se no Brasil, Elisa Lispector é autora e matriz com a qual não podemos deixar de identificar (usando das ferramentas legítimas da crítica biográfica) a personagem da filha mais velha, Lizza.É entre esta e o pai (Pinkhas) que se estabelece o seguinte diálogo:

- Lizza, não se pode viver só a vida inteira. Você não é mais criança, é uma moça culta. Ouça-me. Ainda hesitou um pouco, depois prosseguiu. - Sei de um jovem que se interessa por você. Falaram-me nisso, encontrei-o ontem, por acaso, arrematou. E, como visse conturbado o semblante da filha, ajuntou com severidade:

- Lizza, as meninas estão crescidas. É tempo de pensar nelas.

- Case-as, pois, respondeu serenamente. Que não esperem por mim. Talvez, mesmo, nunca me case, concluiu desviando o olhar. O sofrimento do pai the doía, doía-lhe a própria impossibilidade de aquiescer. [...] - Nem todas as familias são iguais, nem toda gente pode viver do mesmo modo. [...] Cada qual deve seguir o seu destino, viver a própria vida. (LISPECTOR, I97I, I54-155, grifos nossos) 
A cena ilustra a filha primogênita que não segue a regra estabelecida: o desejo de casar-se. E é "preciso" que ela o faça, até para que as irmãs mais novas possam casar. Tem-se um exemplo extremo, em que até a hierarquia e sequência de formação de famílias heteronormativas precisa-se seguir (o pai destaca isso "com severidade"). Há "um jovem que se interessa” por ela, mas Lizza fissura o sistema ao questionar e especular que talvez nunca se case. Até se ressente da "própria impossibilidade de aquiescer", mas é lúcida e instaura a dissidência pela afirmação da liberdade de cada indivíduo para seguir seu caminho e, ainda mais, de que "nem todas as famílias são iguais", porque nem todos podem viver do mesmo modo.

E se apenas por não desejar casar-se a personagem Lizza já sente alguma dor, imaginemos o grau de ruptura instaurado pelo vínculo estabelecido entre pessoas do mesmo sexo. Nessa ligação, questiona-se a "essencialidade" heterossexual da procriação e a manutenção da propriedade privada burguesa pela descendência "legítima". Didier Eribon (2008, p. 27) alude a esta questão em seu livro Reflexões sobre a questão gay, logo no capítulo inicial, muito bem intitulado de "O choque da injúria":

\footnotetext{
'Viado nojento' ('sapata nojenta') não são simples palavras lançadas en passant. São agressões verbais que marcam a consciência. São traumatismos sentidos de modo mais ou menos violento no instante, mas que se inscrevem na memória e no corpo (pois a timidez, o constrangimento, a vergonha são atitudes corporais produzidas pela hostilidade do mundo exterior). E uma das consequências da injúria é moldar a relação com os outros e com o mundo. E, por conseguinte, moldar a personalidade, a subjetividade, o próprio ser de um indivíduo.
}

A violência dessas agressões verbais revela o pavor que a contestação aos papéis e scripts estabelecidos representa. A hipótese repressiva de Foucault é retomada nesse excerto de Eribon e, caso adicionemos aqui as reflexões de Beatriz Preciado (20I4, p. 26), podemos observar este corpo sexuado e gendrado como um texto, que compõe o sistema de escritura sexo/gênero: 
O sistema sexo/gênero é um sistema de escritura. $O$ corpo é um texto socialmente construído, um arquivo orgânico da história da humanidade como história da produção-reprodução sexual, na qual certos códigos se naturalizam, outros ficam elípticos e outros são sistematicamente eliminados ou riscados. A (hetero)sexualidade, longe de surgir espontaneamente de cada corpo recém-nascido, deve se inscrever ou se reinstruir através de operações constantes de repetição e recitação dos códigos (masculino e feminino) socialmente investidos como naturais.

Preciado denuncia com muita argúcia o quão arbitrário é o sistema social de engendramento do sexo, do gênero, das prisões que inflige ao corpo. E a operação de identificação com as noções de sistema de escritura e texto são muito fecundas para o diálogo que estamos estabelecendo entre a literatura e o terreno político-social das formações familiares. Seguindo sua proposição demolidora, Preciado elabora a noção da contrassexualidade, cuja tarefa é identificar os espaços considerados errôneos ("as falhas da estrutura do texto") e reforçar o poder dos desvios e derivações com relação ao sistema "heterocentrado". É preciso, portanto, "sacudir as tecnologias da escritura do sexo e do gênero, assim como suas instituições". (PRECIADO, 20I4, p. 27) Ao se modificarem as posições de enunciação, ou seja, ao experimentar e evidenciar as "epifanias do sexo, de gênero e do corpo", é produzido ruído necessário para desestabilizar o cristalizado edifício das identidades fixadas.

Discutindo o pós-humano e o caráter "prostético" de invenção e fabricação dos corpos (cujo gênero se configura efetivamente na materialidade dos corpos, no entanto esta materialidade é cada dia mais resultado de próteses, tecnologias, modificações estéticas ou funcionais), Preciado revela o quanto há tanto de orgânico quanto de tecnologia na fabricação sexual dos corpos: próteses de silicone, maquiagens, adereços, atividades físicas para moldar músculos. Vem, então, a proposição da contrassexualidade, para reivindicar "a compreensão do sexo e do gênero como cibertecnologias complexas do corpo”. (PRECIADO, 20I4, p. 40) E, invocando a teórica 
feminista Donna Haraway, propõe-se "uma queerização urgente da 'natureza”. (PRECIADO, 20I4, p. 40)

É trazido à discussão o termo "queer": em sua origem a expressão traz carga ofensiva para designar "estranho" ou “esquisito” em relação a um homossexual; reapropriada pela teoria de gênero ligada às correntes de estudos gays e pós-identidade, revela a força política de uma citação descontextualizada de um insulto homofóbico e da inversão de posições de enunciação hegemônicas que este provoca e é assimilada como subversão e autodefinição, não mais como ofensa.

David Halperin, em seu Saint Foucault: towards a gay bagiograpby (cf. I995, p. 86), apropriando-se do termo “queer”, propõe a expressão “queer práxis” para designar a transformação de certas técnicas de dominação em "técnicas de si”, as quais poderíamos entender como modos de construção de identidade que instauram lugares de resistência à dominação. Entre as principais metas do Manifesto Contrassexual, está justamente "aprender a subverter os órgãos sexuais e suas reações biopolíticas”. (PRECIADO, 20I4, p. 59) Através de uma operação nomeada de "inversão-investidura”, desloca-se a força da performatividade do código heterocentrado e se provoca "uma per-versão, uma reviravolta na produção habitual dos efeitos da atividade sexual”. (PRECIADO, 20I4, p. 6o, grifo nosso)

Para descolonizar o sexo, o corpo e o gênero, a contrassexualidade aponta para "práticas contrassexuais como possibilidades de uma deriva radical em relação ao sistema sexo/ gênero dominante" (PRECIADO, 20I4, p. 3I), uma fundamental delas é a "erotização do ânus": banido da lógica erótica heteronormativa, pois é o lugar comum de todo corpo (independente de genitália e binarismo), além de ser centro erógeno, é identificado como zona de passividade e produtor - ao mesmo tempo-de excitação, prazer e de excreção:

O trabalho do ânus não é destinado à reprodução nem está baseado numa relação romântica. Ele gera benefícios que não podem ser medidos dentro de uma economia heterocentrada. Pelo ânus, o sistema 
tradicional da representação sexo/ gênero vai à merda. (PRECIADO, 20I4, P. 32)

É, pois, esta parte comum a todos os corpos um lugar "revolucionário" em essência: sempre que protagonista de prazer ou excitação, desestabiliza as "etiquetas" e a norma dos "bons costumes". É exatamente esta potência que a escritora paulista Hilda Hilst reconhece ao enunciar seus questionamentos metafísicos, na novela $A$ Obscena senbora $D$ :

\begin{abstract}
Ai, Senhor, tu tens igual a nós o fétido buraco? Escondido atrás mas quantas vezes pensado, escondido atrás, todo espremido, humilde mas demolidor de vaidades, impossível ao homem se pensar espirro do divino tendo esse luxo atrás [...], trejeitos, cabeleiras, mas o buraco ali, pensaste nisso? Ó buraco, estás aí também no teu Senhor? Há muito que se louva o todo espremido. Estás destronado, quem sabe, Senhor, em favor desse buraco? (HILST, 1993, p. 54)
\end{abstract}

Humilde e demolidor de vaidades, o ânus é o denominador comum de todos os seres humanos e desses com o divino. A lucidez destas declarações faz da personagem uma "louca" de tão lúcida, proscrita do bom convívio social hipócrita. E também banidos do convívio social se veem outros dois personagens de Hilst, em Rútilo Nada, outra de suas densas e provocativas criações na qual se estabelece uma trágica família destoante dos moldes heteronormativos. Lucius Kod é o jornalista de 35 anos (filho de um banqueiro bem-sucedido) que se descobre apaixonado por Lucas, namorado de sua filha. Enredo trágico (a própria autora invoca na narrativa um costume da clássica cidade grega de Cartago, em que sogro e genro não se podiam separar) que desnuda o quanto o comportamento moralista heteronormativo reage e condena qualquer desvio a suas normas. Lucius é agredido pelo pai. Assim explode a reação do banqueiro ao envolvimento afetivo do filho com o namorado da neta:

[...] então anos de decência e de luta por água abaixo e eu um banqueiro, com que cara você acha que eu vou aparecer diante de meus 
amigos, ou você imagina que ninguém sabia, crápula, canalha, tua sórdida ligação, e esse moleque bonito era o namoradinho da minha neta [...]. gosta de cu seu canalha? gosta de merda? fez-se também de mulherzinha com o moço machão? (HILST, I993, p. I4- 15)

Saliente-se que este mesmo banqueiro beija os lábios do "moleque bonito" Lucas, quando vai conferir o "serviço de espancamento" que manda seus capangas executarem e em decorrência do qual o rapaz acaba por morrer. É verbalizada por Lucas a "dor de não ter sido igual a todos" (I993, p. 24) - volta a figura da injúria e da agressão já mencionada por Eribon - e resta a Lucius o desencanto de reconhecer-se, mas ser proscrito, e o desencaixe na identificação binária, estereotipada: "Eu não sou o que sou, fico me repetindo, nem fêmea alguma e macho muito menos me colocaram aqui neste tempo onde estou, tempo desordenado, avessos de um rumo [...]”. (1993, p. 2I).

Fica evidente o quanto qualquer definição é uma limitação, impede as sucessivas epifanias/revelações do ser em suas relações com seu corpo/gênero/sexo e suas práticas de afeto. Cabe, pois, aos escritores expandirem seus alcances. Foi assim também com Caio Fernando Abreu, ficcionista e dramaturgo gaúcho, jornalista, ator, vítima da Doença da Imunodeficiência Adquirida (Aids) em um momento de estigmatização desta como uma doença gay. Sua obra revela as uniões que escapam da formação familiar burguesa heteronormativa e frequentemente seus personagens traduzem o desencaixe social: a vida nos guetos ou, emblematicamente, como diz a personagem-narradora do conto "A Dama da Noite": "Você tem um passe para a roda-gigante, uma senha, um código, sei lá. [...] então o cara deixa você entrar, sentar e rodar junto com os outros. Mas eu fico sempre do lado de fora." (ABREU, I988, p. 9I) É a voz de uma travesti em um bar, à noite: único lugar em que ela pode circular. $\mathrm{O}$ título do livro no qual consta este texto é Os dragões não conbecem o paraíso, metáfora a traduzir o quão outsiders são esses seres "exóticos” da fauna desviante. 
E se pensamos em o quanto a simples existência de comportamentos e a produção de desejos que não seguem, que questionam ou contrariam a norma causam de desestabilizações na ordem social, imagine-se o que causa uma família como a que cria e propõe o ficcionista, dramaturgo, ator e desenhista argentino Raul Botana (o qual assinava sob o pseudônimo Copi) ao criar obras como: L'Homosexual ou La difficulté de s'exprimer (ou O Homossexual ou a dificuldade de expressar-se), em que a personagem Irina - espécie de protagonista e centro dramático - é uma transexual filha de outra transexual que é, na verdade, sua mãe, e também é seu/sua amante e nada tem de parentesco sanguíneo com ela.

GARBO: Onde conheceste madame Simpson, Irina?

IRINA: No Egito.

GARBO: Ela realmente tem algum grau de parentesco contigo?

IRINA: Não.

GARBO: Por que tu estás com ela? Ela decidiu por ela mesma ser tua mãe e tu aceitaste sem pestanejar?

IRINA: Sim. (1984: 7I-72, tradução nossa do original francês) ${ }^{4}$

E há muito mais. São cinco personagens: além de Irina e sua mãe (Madame Simpson), Madame Garbo (professora de piano e amante de Irina; também transexual, tem um pênis), o oficial Garbenko (marido dessa) e o general Pouchkine. O cenário é a Sibéria. Irina é o centro em torno da qual gravitam todas as relações e as outras personagens.

Irina está grávida, não se sabe de quem: ora ela afirma ser de sua mãe (Madame Simpson), ora de Madame Garbo (sua amante e professora de

4 Garbo: Où est-que tu as connu madame Simpson, Irina?

Irina: En Égypte.

Garbo: Est-ce qu'elle a un vrai lien de parenté avec toi?

Irina: Non.

Garbo: Pourquoi es-tu avec elle? Elle a décidé comme ça d'être ta mère et tu l'as suivie? Irina: oui. (1998: 71-72) 
piano), ora de um travesti "pequeno e louro" com quem fornica nos banheiros da estação de trem, ora do oficial Garbenko. Mas Irina "defeca” o bebê. Sim, ela o aborta pelas vias fecais (provavelmente por onde recebe esperma, sendo uma homossexual/transexual de homem para mulher).

Em trecho de diálogo em que Madame Garbo questiona Irina sobre a sua decisão pela mudança de sexo, constatamos como ecoa nossa proposição do gênero como epifania e, também, os princípios que devem reger uma sociedade contrassexual, segundo Preciado, na qual as explorações das diversas mudanças de sexo/gênero devem ser franqueadas:

GARBO: Por que mudaste de sexo?

IRINA: Eu já tinha começado.

GARBO: Mas tu tinhas apenas colocado seios. No início, não querias mudar de sexo.

IRINA: Mas depois eu quis mudar de sexo.

GARBO: Por quê?

IRINA: Eu já tinha começado.

GARBO: Por que tu quiseste pôr seios?

IRINA: Eu queria ter seios.

GARBO: E tu não querias mudar de sexo.

IRINA: Não.

GARBO: Então, foi depois de conhecer madame Simpson que tu quiseste mudar de sexo. Foi madame Simpson quem te pediu para mudar de sexo?

IRINA: Não.

GARBO: Foi o tio Pierre?

IRINA: Não.

GARBO: E quem foi? 
IRINA: Ninguém. Eu mesma quis mudar de sexo. Ninguém me sugeriu isso.

GARBO: Tu me disseste que no começo não querias mudar de sexo. Tu só querias pôr seios. Só depois de conhecer madame Simpson e tio Pierre foi que quiseste mudar de sexo. Por quê?

IRINA: Não sei.

GARBO: Deve haver uma razão. Tente achá-la. Por quê?

IRINA: Eu queria mudar de sexo.

GARBO: Tu querias ter um sexo de mulher em vez de um sexo de homem?

IRINA: Sim, foi isso.

GARBO: Mas, por quê?

IRINA: Porque eu queria. (I998: 83-86, tradução nossa) ${ }^{5}$

${ }^{5}$ Garbo: Pourquoi as-tu changé de sexe?

Irina: J'avais déjà commencé.

Garbo: Mais tu t'étais fait seulement pousser les seins. Au début, tu ne voulais pas changer de sexe.

Irina: Mais plus tard, j'ai voulu changer de sexe.

Garbo: Pourquoi?

Irina: J'avais déjà commencé.

Garbo: Pourquoi est-ce que tu t'es fait pousser les seins?

Irina: Je voulais avoir des seins.

Garbo: Et tu ne voulais pas changer de sexe.

Irina: Non.

Garbo: Alors c'est après avoir connu madame Simpson que tu as voulu changer de sexe.

C'est madame Simpson qui t'a demande de changer de sexe?

Irina: Non.

Garbo: C'est l'oncle Pierre.

Irina: Non.

Garbo: C'est qui?

Irina: C'est personne. J'ai voulu changer de sexe toute seule. Personne ne me l'a dit.

Garbo: Tu m'as dit qu'au début tu ne voulait pas changer de sexe. Tu ne voulais pas changer de sexe. Tu ne voulais que te faire pousser les seins. Ce n'est qu'après avoir connu madame Simpson et l'oncle Pierre que tu as voulu changer de sexe. Pourquoi?

Irina: Je ne sais pas. 
Voltando ao enredo da peça e à ideia de reprodução, Madame Garbo também teve um bebê, em seu passado. Era uma mulher e tem um filho que rejeita e mata. Como castigo, seu pai a faz receber o implante de um pênis e ela se torna mais uma transexual desta galeria de Copi. Seu marido, o oficial Garbenko, a ama mesmo assim, mas é muito compreensivo (apesar de também ser amante de Irina), quando Madame Garbo resolve admitir sua paixão por Irina e pede a ele ajuda para fugir com sua amada para a China. Vale salientar que a mãe de Irina (Madame Simpson) irá junto. Por fim, tudo é apresentado com um humor afinado e que não perde ritmo. Irina, porém, encerra a peça cortando a própria língua: talvez para ilustrar a dificuldade de expressar o que é toda esta liberdade de poder se construir a tecnologia do corpo contrassexual conforme suas epifanias. Destaque-se ser uma dramaturgia de i97i que põe em cena literalmente muito do que irá teorizar nos anos 2000 a filósofa Beatriz Preciado.

Copi nasceu em Buenos Aires em 1939, filho de uma família ligada ao jornalismo, à política e às artes. Seu avô materno era Natalio Botana, fundador e diretor do Diário Crítica, lendário jornal argentino. A avó materna era Salvadora Medina Onrúbia, já mãe solteira de um filho quando se casa com Natalio, dramaturga, envolvida em casos fortuitos de lesbianismo. Dela vem o apelido com que o neto se tornaria conhecido. Aliás, apelidava todos os filhos e netos para evitar que fossem enfeitiçados. O pai de Copi, Raul Taborda, era jornalista e artista plástico. Durante a ditadura peronista, opôs-se radicalmente ao general Perón e toda a família acabou por precisar se exilar. Copi chegou a Paris com I6 anos de idade, onde se fixou até morrer em 1987, em decorrência da Aids. Convenhamos: também não se tratava de uma família muito convencional a deste escritor, que tinha o

\footnotetext{
Garbo: Il doit y avoir une raison. Essaie de la trouver. Pourquoi? Irina: Je voulais changer de sexe.

Garbo: Tu voulais avoir um sexe de femme au lieu d'um sexe d'homme?

Irina: Oui, c'est ça.

Garbo: Mais pourquoi?

Irina: Parce que je voulais. (1998, 83-86)
} 
hábito de nomear diversos de seus personagens com seu próprio apelido, o que aponta para o extremo grau de ficcionalização de si que praticava.

Suas criações envolvem frequentemente a quebra de paradigmas e fronteiras; suas personagens podem ser gays, lésbicas, heterossexuais, animais. Travestir-se, cambiar-se é a operação fundamental em sua galeria de criaturas; como ele próprio atuando. Em várias entrevistas era questionado sobre sua (homo)sexualidade e respondia que esta não era uma "condição forçosa” e muito menos que moldava sua visão de mundo; também respondeu ironicamente quando inquirido sobre se quis ter filhos:

Depois estão os filhos de todo mundo, são filhos meus; não tenho uma frustração de paternidade, pelo contrário, penso que os filhos dos meus amigos [...] são muito amigos meus e de alguma forma mais ainda que seus pais; de certo modo, em algum nível argentino, eu seria 'a tia Marica', isso existe, isso existe. ${ }^{6}$

Além de transgressor em sua obra, dava declarações provocativas nas entrevistas: invocava a urgência da questão feminina na Argentina (país de larga tradição patriarcal machista); afirmava o quanto adorava fazer-se de travesti no teatro (encantava-se de atuar em trajes femininos; mas também ao travestir-se em animal) e, ainda, ao afirmar que as travestis é que se vestiam como mulheres (nos anos I970 e I980) e que ser mulher não era simplesmente ter "um par de tetas" ou uma vagina (genitais normatizados como femininos); pois isso ele também tinha. São tão somente zonas erógenas e o sexo está para além das prisões fixas das identidades normativas e dos genitais assim compreendidos.

Talvez por este ambiente de maior liberdade, sempre o clã familiar criado por Copi desempenha seus papéis e as relações sob a inflexão das epifanias de gênero e sem restrição alguma. No romance La Guerre des Pédés (ou A Guerra

${ }^{6}$ Después están los hijos de todo el mundo, son hijos mios; no tengo una frustración de paternidad, al contrario, pienso que los hijos de mis amigos [...] son muy amigos mios y de alguna manera más que sus padres; de cierto modo, en algún nível argentino sería 'la tia Marica', eso existe... eso existe. (TCHERKASKI, 1998, p. 44) 
dos Pederastas), a idealização de uma família perfeita é proposta: a Brigada Interespacial Homossexualé um grupo ativista gay que procura melhor rumo para a sociedade. Para tanto, encontra o personagem Copi e o convence de que ele precisa procriar com outra personagem: uma brasileira do Amazonas, hermafrodita perfeita, chamada Conceição do Mundo (nome literalmente simbólico: a concebedora do mundo, do novo mundo a vir). E se pergunta o personagem Copi, sob a ironia mordaz do autor: "Que espécie de filho poderei ter, eu, pobre homossexual que jamais sonhei em me reproduzir?" (I982, p. I48, tradução nossa).? Mas este personagem será "o primeiro herói gay sobre a Lua” (I982,p. 159), justamente por principiar um novo mundo.

Do enlace entre Copi e Conceição do Mundo nascerá o primeiro "Homossexual sapiens" e irão povoar a lua a partir deste primevo clã de peculiares novos "Adão e Eva”, pois a terra já não parece mais ter cura de sua doente sociedade heterossexista hipócrita, falso-moralista e castradora. $\mathrm{O}$ chefe da Brigada Homossexual, fincada a bandeira gay na lua, sentencia esta criação de um novo mundo possível, muito melhor e mais liberto: "Sei que levaremos muito, muito tempo para compreender, mas de agora em diante nós nos encontramos na realidade do Universo e não naquela da nossa Terra; nós estamos na Utopia, Copi!” (COPI, I982, p. I67). ${ }^{8} \mathrm{E}$ a utopia é o pleno exercício de existir em liberdade.

\section{Das vias abertas às permanentes inconclusões}

Se relembrarmos a declaração do personagem Lucius Kod (I993, p. 2I), (de Hilda Hilst, citada anteriormente), quando se diz "nem fêmea nem macho", mas um ser complexo colocado em um "tempo desordenado", como "avessos de um rumo" não podemos evitar o apontamento cons-

7 Quelle sorte de fils allais-je avoir, moi, pauvre homosexuel qui n'aurais jamais songé à me reproduire? (1982: 148)

8 - Je sais que l'on met très, très long temps à le comprendre, mais désormais nous nous trouvons dans la réalité de l'Univers et non dans celle de notre Terre; nous sommes dans I'Utopie, Copi! (1982: 167). 
ciente de que algo está errado nesta ordem que desrespeita os seres em sua potência.

Muito precisamente toca nesse mesmo ponto Alberto Manguel (2000, p. 35):

Todo grupo que é objeto de preconceito tem isto a dizer: somos a língua em que somos falados, somos as imagens em que somos reconhecidos, somos a história que somos condenados a lembrar porque fomos barrados de um papel ativo no presente. Mas somos também a língua em que questionamos essas pressuposições, as imagens com que invalidamos os estereótipos. E somos também o tempo em que vivemos, um tempo de que não podemos nos ausentar. Temos uma existência própria, e não estamos mais dispostos a permanecer imaginários.

O objeto artístico é transtemporal (inscreve-se em seu contexto de produção, mas torna-se "presentificável” a cada nova fruição) e acorda o leitor ou o público da anestesia, para fazê-lo despertar e reconhecer que seu papel social é, também, crítico e político, ao fazer sua "leitura a contrapelo”. As obras e as vozes de seus criadores aqui trazidas à cena revelam a mesma urgência: desmascarar a norma instituída e a falácia que representa um estereótipo único e pasteurizado de parentalidade. Instauram-se, pois, nesses universos artísticos, novos e melhores "mundos possíveis" para seres que são humanos e "pós-humanos" e querem simplesmente ser, exercer-se e viver.

\section{Referência}

ABREU, C. F. Os dragões não conbecem o paraíso. São Paulo: Cia. das Letras, 1988. BOURDIEU, P. A dominação masculina. Rio de Janeiro: Bertrand Brasil, 1999. 
COPI. L'Homosexuel ou La difficulté de s'exprimer. Paris: Christian Bourgois, 1998.

COPI. La Guerre des Pédés. Paris: Albin Michel, 1982.

DELEUZE, G. Ilha deserta. São Paulo: Iluminuras, 2005.

ERIBON, D. Reflexões sobre a questão gay. Rio de Janeiro: Companhia Freud, 2008.

FOUCAULT, M. História da sexualidade I: a vontade de saber. Rio de Janeiro:

Graal, 1997 .

GOMES, R. C. Todas as cidades, a cidade. Rio de Janeiro: Rocco, 1994.

HALPERIN, D. Saint Foucault: towards a gay hagiography. New York: Oxford University Press, 1995.

HILST, H. Rútilo nada/ A obscena senbora D./ Qadós. São Paulo: Pontes, 1993.

LISPECTOR, E. No exilio. 2. ed. Brasília: Ebrasa, I97I.

MANGEL, A. No bosque do espelbo: ensaios sobre as palavras e o mundo. São

Paulo: Cia. das Letras, 2000.

PRECIADO, B. Manifesto contrassexual: práticas subversivas de identidade sexual. São Paulo: n-I, 2014.

TCHERKASKI, J. Habla Copi: homosexualidad y creación. Buenos Aires:

Galerna, 1998. 


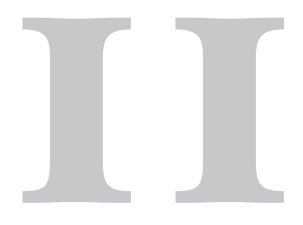

\title{
(Micro)políticas Queer
}

\author{
获 \\ Fernando Pocaby
}

Este é um ensaio de uma cartografia de (micro)políticas queer. Busco com isso problematizar e, pretensiosamente, perturbar o trabalho das milícias epistemológicas das autointituladas ciências da subjetividade - campo em que me movimento, especialmente entre as práticas-saberes da educação e da saúde. A aposta do texto persegue algum tipo de encontro com as fechações/aberturas pós-estruturalistas presentes nas

${ }^{1}$ Comunicação produzida para o IV Enlaçando Sexualidades. Salvador, 26-29 de maio de 2015. Este texto é versão parcial e revisitada de um dos quatro atos (a ato produzido por este autor) que compõem o artigo-manifesto queer "Transconversações queer: sussurros e gemidos lusófonos". Quatro cadelas mirando a(s) Psicologia(s), publicado em 2014 na Revista Periódicus por Fernando Pocahy, Fernando Teixeira Filho, Nuno Santos Carneiro e Wiliam Siqueira Peres. 
insubordinações e nos tráficos de significados acionados na experiência das (micro)políticas queer na pesquisa acadêmica e na produção de subjetividades no campo das políticas educacionais e científicas universitárias.

A escrileitura de mundo que se agencia entre estas poucas páginas não é nada mais do que uma reação alérgica à herança binária do "isto ou aquilo”, à falta (e ao império do falo) como elemento capitalístico-ressentido-dominador, à assunção neuro-farmaco-digital e ao conjunto de interpelações representacionais presentes nas renovadas taxonomias pós-positivistas que marcam a vigilância das subjetividades sob a tutela da heteronormatividade (e seus derivados, como a homotransnormatividade).

Muitas instituições e pessoas entram em pânico diante de qualquer possibilidade de desterritorialização. Encontram-se aflitos diante da perda ou abalo de um suposto "eu" que, a duras penas, tentam (auto)fixar. Outros, sentem-se acuados pelos gladiadores normaloides da moral (não somente aqueles da Igreja Universal, mas todos e todas que se curvam à vontade de poder e exercem suas forças de dominação e terror social - acadêmico, político, estético) e agonizam, como vidas vazias. Atônitos, reagem de forma perversa e raivosa diante movimentos que lhe retiram alguma segurança de individuação. Vociferantes e desejosos de norma, atacam com gritos e panelaços gourmetizados. Suplicam em cânticos religiosos, acadêmicos ou no(s) documento(s) legislativo(s) que Deus ou a ciência os livrem do desmanchamento de suas certezas e de seus privilégios. Pobres vítimas cis-brancas!

Com seus panelaços fazem passar seus fundamentalistas (acadêmicos, religiosos, políticos e até artísticos), assombrando e vigiando devires vadios. Às vezes, por meio de nuances moderadas de patologização das diferenças e alguma concessão, como se fossem donos de algo na vida, toleram-nos a contragosto. Suas práticas molares estão (a)fundadas em desejos de (hetero/homo)norma. Passam dias e vidas ruminando interpretações teológicas ou mesmo científicas - metateóricas - espraiando seu suposto saber, seu saber-poder, suas vontades de poder, no cotidiano das práticas sociais e institucionais, barganhadas em cenas parlamentares ou outros sítios de poder. 
Por vezes, assumindo ares de renovada visitação epistemológica, exibem com um sorriso branco (claro, apegada a um modelo racializador da vida) seus murmúrios de preocupação e suposto entendimento e implicação com as coisas do mundo, oferecendo migalhas sociais aos ditos desviantes e enjeitados da moral familiar burguesa e neoliberal. Monótona e perigosíssima prática dominada pela suposição de um corpo-subjetividade como lugar de verdade. Artífices da própria ficção epistemológica que performativamente intentam realizar materializam-se milicianos da moral e do desejo de morte.

No plano da produção científica colonial, as disciplinas científicas (e apaixonadas pelo poder) se assenhoram dos desejos (para elas, sempre ressentidos e assombrados pelo nome do macho), afastando qualquer conexão com a cultura do presente ou da cultura como plano vivo de insubordinações cotidianas. Percebem quase tudo, mas não se veem em nada do que produzem. Tampouco (se) enxergam. Nada percebem, além do seu apreço pelo cálculo ou pelas inferências e interpretações morais. Seus mapas computadorizados, suas inúmeras combinações e probabilidades, seus enquadramentos/enjaulamentos teóricos e suas interpretações universalizantes não fazem mais do que cintilar a vontade de saber/poder espalhadas por zonas generificadas do corpo ou nas zonas "ainda" desconhecidas. Entre as novas disciplinas e suas apostas teórico-capturantes, arranjos de novas biopolíticas emergem, sugerindo imagens ultra-atormentadas de representações (marcas de poder) de gênero e sexualidade descoladas de qualquer potência de vida. Cienciazinhas/disciplinas enroscadas em performances estatísticas ou significados congelados que não somam mais do que dois e dois diante do (ficcional) social, repetem em coro o cálculo binário da dor: julgam que as pessoas ou são isso ou são aquilo outro. Produto final desta pobre engenharia - performatividades normofásicas/normofálicas.

$\mathrm{Na}$ cama contemporânea de Procusto forja-se um ideal de humano gendrado e atormentado com a sexualidade. A normalização macia desse hospedeiro que, segundo sabe-se da mitologia grega oferecia uma cama na exata medida de seus hóspedes, cerrando-lhes as partes excedentes ou 
espichando as partes faltantes para que coubessem no leito ofertado aos forasteiros, cobre-se (e encobre-se) de um lençol roto de interpelações e traduções normativas da experiência do corpo e, mais amplamente, das derivas e dos devires que inventam a vida. Esquecem-se que tudo é fabricado na cultura. Tudo, no jogo político da agonística de um ideal de humano, é fabricado, ficcionado nas experiências inconfessáveis do devir (se capturam algo, é a sua própria ficção chapada em representações autoconfirmativas de seus delírios de determinação do lugar do outro).

A ciência moral e seus gladiadores epistemonormoides se colocam com o bisturi discursivo da cultura. Não desejam enxergar que a ciência é parte de nossas culturas. Não somos tolxs e sabemos bem que teorias assumem legitimidades em matrizes sexistas, heterossexistas, racistas e, incontestes, produzem a realidade que intentam descrever - performativamente. Estudos e práticas que falam pouco a linguagem que faz corpo, mas fazem o corpo arbitrariamente falar - suplício de confissões, medidas e mesmices interpretativas, cujos refinamentos conceituais não escondem a nova dinâmica biopolítica e neoliberal. Tudo parecendo tão novo. Mas nada menos Moderno.

A heterossexualidade compulsória e a cisgeneridade reinam soberanas no imaginário falo-edipiano de guardiães da norma, gozando (e às vezes só falam deste tal de gozo) de privilégios por conta de suas supostas naturalidade e recompensas por um calendário (re)produtivo do capitalismo neoliberal. Essa ficção biopolítica tece o triste cotidiano das práticas cães de guarda. (ROLNIK, 1997) O rosnado da matilha de guarda conta ainda com a comoção interdisciplinar de um conjunto de subjetividades dobradas a campos de saberes seduzidos e sedutores em planos normativos e moralidades canônicas, estejam elas para as humanas ou para as outras ciências da natureza - cuja arbitrária divisão já revela a atormentada vontade de dividir e de classificar o mundo.

Mas isso tudo não sem recusa, não sem resistência. E é nessa agonística por onde se articulam o que se denominou chamar (micro)políticas queer. Sorte de plano-tática de contestação. Com suas epistemologias de 
mundo profanadoras, inquietas, abusadas, radicalmente promíscuas, suadas, gordas e transbordantes de impaciência diante dos coronéis da nova ordem política nacional (esteja esta nova ordem na academia, na igreja, nos legislativos e outros lugares-práticas de polícia social), multitudes de corpos em fuga fazem a vida pulsar, instaurando outras formas de organização e coletividade apaixonadas pela fluidez e pelo prazer como invenção ético-estético-política da vida contemporaneidade.

E (a meu ver, ou de onde eu alcanço alguma coisa para ver) é na formação em educação e saúde por onde o latido vadio das subjetividades queer torna-se mais barulhento e por onde podemos acompanhar algo mais de sua agonística. Não é atoa que os ataques fundamentalistas tem atingido de forma mais significativa esses dois campos que, nas últimas décadas, assumiram protagonismo na agenda democrática: educação e saúde fortaleceram-se como espaços de ampliação das ferramentas democráticas, hoje ameaçadas.

As inquietações indisciplinares e indisciplinadas agenciadas nos movimentos queer denunciam: a sexualidade está saturada de disciplina. E em aproximação aos latidos discursivos-desconstrucionistas (e desconfiados), o manifesto-reflexão antinormalização queer engorda, explodindo as significas do corpo dócil e útil - ou, mais contemporaneamente, o corpo elástico e biodinâmico.

A alergia social queer age de forma tática e deliberada através do dissenso. Como política epistemológica, como experimentação (re)inventiva do fazer-corpo e ainda como fazer acadêmico em movimentos minoritários, dissidentes, estudiosxs-ativistas queer assumem, como ponto de partida, a proposição de que a pesquisa, a arte, as formas de associativismo e a feitura de nossas práticas sociais são produzidas a partir de jogos de poderes-saberes-prazeres que são vividos sem nenhuma estabilidade, sem nenhuma promessa de vida certa.

Estou convencidx de que pesquisar-produzir conhecimento na experiência queer é uma prática de resistência, efeito da agonística contemporânea dos processos de subjetivação. A produção de potência 
de vida queer encontra-se com a radicalização de uma epistemologia de mundo engendrada no desvio e desde as vidas constituídas no avesso das normas, muitas vezes vidas precárias. Mas a potência de não curvar-se e de (des)dobrar-se epistemologicamente sobre si mesmx e logo abandonar ou se instalar de algum lugar seguro não é vivida sem risco de captura, aliás, este é o jogo, desterritorializar, reterritorializar, desterritorializar... territorializar.

O desatino impertinente e indisciplinado presente nas políticas queer - como algo que não pode ser localizado, mas uma composição epistemológica mutante e contexto-dependente - segue no rastro de tantxs outrxs que se movimentaram em posições dissidentes anticoloniais, antirracistas, antissexistas. Posições interseccionadas com as sexualidades, os corpos e as performances de gêneros minoritárias, emergem não como objetos de investigação, mas como políticas de conhecimento e de tessitura de novas subjetividades. Nessa posição, o corpo-política queer na experiência da formação acadêmica e nas demais práticas sociais entra/aparece como superfície de intensidades e de (des)encontros problematizadores, desumanizando-se das encarnações científicas canônicas, assépticas e morais dos normo-investigadorxs - "toxicômanos de identidade" (ROLNIK, I994) e dos bandos fundamentalistas que disputam zonas de poder.

Entende-se que as políticas queer afirmam-se no cotidiano como (com) posição implicada em combater os fascismos que estabelecem quais vidas valem a pena ser vividas e quais são as que não importam, como nos incita $\mathrm{e}$ excita a pensar Butler (2005). Disto, somos levadxs a pensar que os nossos lugares de pesquisadorxs são marcados por convenções e normas sociais; e que os nossos modos de pesquisar são constituídos por epistemologias "duras" (molares) hierarquizantes ou (moleculares) contestatórias (talvez). Pesquisar/combater/resistir, em uma disposição queer, poderia significar, nesses termos, o agenciamento de uma profusão de estranhamentos sobre as formas de saberes/poderes/prazeres e, ainda, daquilo que é possível conhecer e quem estaria autorizada(o) a produzir conhecimento, como bem já nos apontou Guacira Lopes Louro (2004), pesquisadora que movimentou/ 
atormentou o campo da educação com suas apostas nos estudos queer (a quem faço minhas reverências, não como pessoa sagrada, mas como subjetividade profana, uma orientadora suave e forte, corajosa em seu campo de batalha: a educação).

No rastro destas ideias, acredito que faz sentido pensar em uma produção de conhecimentos entre os lençóis discursivos dos prazeres envolvendo as sexualidades e as performatividades de gênero sem desconsiderar as interseccionalidades com outros marcadores de identidade e de diferença que operam na produção de modos de experimentação de si, movimentando-nos em posições de desigualdades sociais ou de assujeitamento aos microfascismos cotidianos que servem de elemento de localização nas diversas aduanas da vida social. Essas interseccionalidades são formas (discursivas) que organizam os prazeres e os modos de experimentação das sexualidades e não somente a sua opressão/controle/tutela/normalização.

Desenha-se assim o princípio ético nesse plano-potência queer. Entre as formas de conduzir-se a si mesmxs, toma corpo a ideia de recusar parresiasticamente aos bons, limpos e docilizados costumes acadêmicos (como dirá Foucault, a coragem é sempre física). De alguma forma, na insubordinada e inapreensível experiência queer, a desconstrução é sua prática-método, acionada na direção-tática de demover os instituídos das formas hegemônicas de produzir conhecimento, perturbando as epistemologias (con)sagradas e apaixonadas pela "Verdade", pelo poder-saber-poder. Desconstrução que não tem necessariamente a ver com destruição, embora muitos dos embates necessitem de atos potentes e performáticos no sentido de derrubar os muros da apartheid social e cultural agenciado na cena contemporânea, movidos em uma cena cuja dimensão dos perturbados prazeres se oferece também como mais um elemento nessa agonística social do humano contemporâneo.

A forma que muitos dos combates queer assumem sugerem alguma sorte de libertinagem. Mas isto nada teria a ver com liber(t)ação. Trata-se da dissidência científica através de uma postura safada, epistemologicamente apaixonada por um devir-puta. De certa forma busca-se a proliferação da polêmica e do escândalo. E reafirma-se olho no olho que a visualidade da 
pesquisa e do fazer acadêmico é, desde sempre, posicionado na trama dos dispositivos de gênero, classe, sexualidade e de raça. De modo que, diante disto, não se pode jamais desconsiderar a própria experiência corporal do agente pesquisador como alguém também elx assujeitadx por uma produção discursiva que porta as marcas de certa inteligibilidade social, que são recitadas cotidianamente e legitimadas por instituições excludentes, racistas, sexistas e classistas. Assim, como movimento perturbador para a pesquisa, a postura-aposta queer nos lança a desafios relacionados a pensar-fazer (a prática refletida da liberdade, nos termos foucaultianos) como sujeitos engajadxs politicamente nos movimentos de críticas/análises dos processos de autoridade que "a Teoria” confere.

De minha parte, tenho pensado que uma das possibilidades que poderiam se articular a esse modo de operar em pesquisa segue no rastro atormentado da perspectiva genealógica à la Nietzsche, à la Michel Foucault. Como ferramenta conceitual importante para o trabalho de problematização das condições de possibilidade e de emergência dos discursos - que se opõem e/ou associam-se nos jogos de verdade que dão contornos à relação dxs sujeitxs consigo mesmxs, ou seja, no processo de sua (auto)constituição e do conhecimento e dos prazeres-saberes que produzem - trata-se de recusar métodos descritivos que priorizam a constância histórica ou o traço “antropológico" imediato. (FOUCAULT, 2004) Tomaz Tadeu da Silva (2007) faz eco a isso: segundo ele, o mundo estático e morto das coisas e dos significados fixos é um mundo sem disputas.

Por isso as (micro)políticas queer buscam a disputa e dissenso enquanto movimento tático, pois somos todxs restos e rastros desse mundo arregimentado por ilusões normativas, pela suposta segurança da normalidade, ficções de nosso tempo. E como tal, aqui ou ali flertamos com alguma norma, desejosxs de algum conforto e reconhecimento, desejos de alguma sorte de poder ou uma mínima certeza. Nesse sentido, dizer-se/autonomear-se queer já seria, em si mesmo, docilizar o estranho, o bizarro, o ignóbil, o que quer escapar. E talvez eu tenha feito isso em 
algum momento neste texto. Afinal, toda apropriação pode funcionar como forma de sujeição.

Mas se aceitarmos que nenhum texto é sagrado, como já afirmaram tantxs entre aquelxs que operam em perspectivas pós-críticas e pós-humanas, torna-se mesmo arriscado inventar e radicalizar o sentido de "fabricantes" de problemas sobre nosso tempo. Para isso, precisamos de novos e outros modos de pesquisar e intervir. Talvez aqueles modos que tenham a ver com um tipo de curiosidade "vadia" e não com aquela curiosidade perversa que busca assimilar o que convém conhecer, senão aquilo que nos permitiria desfazer, inclusive declinar de ser interpeladxs como queer.

Mais um ataque foucaultiano da matilha queer, anticães de guarda. Queer é também texto. Por isso, não basta Lattes, tem-se que morder, revisitando uma frase atribuída a Gilles Deleuze que, fato ou não, é capaz de produzir sentido: aqui não adianta latir, tem que morder. Mas temos de fazer isso também desde o interior dessas práticas e instituições. É nessa disposição que alguém que se instala em um lugar/fazer acadêmico tem a chance de pensar os problemas de seu tempo, a partir das experiências desmoralizadas e desmontadas de suas próprias subjetividades - bricoladas em e desde seu tempo, em e desde sua cultura - de suas próprias instituições.

Como provocação final, cabe ponderar que um dos efeitos queer na cena acadêmica também nos remete a um plano de pesquisa(in[ter]venções) como modo problematização que escarnifica os regimes discursivos que se organizam a partir da gestão da vida, historicizando o presente em suas formas de controle, deciframento, incitação para o corpo dócil e útil - na ordem e na organização espacial e institucional das subjetividades. Pesquisar-intervir-viver nas fronteiras - lá pelas brechas, entremargens, diante e com o que e quem escapa/foge - nos permite deslocar os gêneros e as sexualidades dos lugares centrais de chaves de acesso à verdade dxs sujeitxs, no mesmo instante em que podemos, assim, desestabilizar as pretensas naturalidade e evidência da heterossexualidade (e até mesmo da homossexualidade, em sua paixão pela origem, identidade ou essência) 
e os desesperados movimentos normalizadores. Talvez, trate-se ainda de induzir políticas diante de efeitos de verdades - nos quais se fabrica qualquer coisa que ainda não existe, afirmou Foucault (200I).

Ao reafirmar o caráter fabricado/ficcional e político de uma pesquisa (in[ter] venção) e dos sujeitos que fazem pesquisa, questionando o lugar de quem pode ou não dizer ou conhecer algo, estamos contestando as formas autorizadas do conhecer e de quem está autorizadx a conhecer. As cadelas de Nietzsche já nos morderam profundamente e propagaram entre nós a raiva epistemológica que faz alguns de nós vidas (vadias) abjetas na academia. O latido reverbera: toda vontade de classificação e de interpretação objetivadora é uma vontade de poder.

A pesquisa e a in[ter] venção podem ser planos de criações culturais. A pesquisa-fazer acadêmico como agente do devir, como plano de invenção de movimentos éticos, estéticos e políticos, pensando-vivenciando o corpo como uma força possível para multitudes de prazeres e de sentidos nômades, inclassificáveis. Arrisco sugerir que nos caberia em uma reverberação queer um trabalho mais indisciplinado sobre nós mesmxs (mas não menos rigoroso e vigoroso), começando por não desejarmos saber quem somos, para não cairmos na armadilha de permanecer xs mesmxs, do mesmo modo como já nos advertiu Foucault (2004, p. 20): "vários, como eu sem dúvida, escrevem para não ter mais um rosto. Não me pergunte quem sou e não me diga para permanecer o mesmo: é uma moral de estado civil; ela rege nossos papéis. Que ela nos deixe livre quando se trata de escrever".

No avesso dos bons costumes acadêmicos, uma in(ter)venção: movimentarmo-nos em cartografias-práticas ético-estético-políticas, a começar por uma análise sobre nossas próprias subjetividades produzidas no campo minado da(s) episteme(s) de nosso(s) tempo(s)-espaço(s)-lugar(es). Qualquer definição de um impacto queer sobre estas práticas-campo seria um ato normo-colonizador. Não se deseja a ontologia do eu ou de um modo de fazer que seria melhor que outro, mas estamos mais interessadxs naquilo que nos tornou um eu classificável, governável, "supostamente" 
real e supostamente incontestável em sua materialidade física. Não se reivindica no plano queer algum lugar ou status na hierarquia dos valores acadêmicos diante do uso das teorias e conceitos perturbadores. Flertar como os modos de vida-pensar queer, com as suas micropolíticas, convida a que revisitemos nossos próprios tormentos e os riscos que derivam de alguma paixão pelo poder em nossas recaídas normapatas.

Não creio que se esteja desejosx de ser ou se reconhecer queer. Estamos em busca de qualquer coisas ou nome que nos faça escapar - entrada-saídamovimento de fazer fugir a partir de um plano de curiosidades que ousa lamber, latir e até morder, mas sem nome e sem pedir licença para existir.

\section{Referências}

BUTLER, J. Humain, inbumain. Le travail critique des normes. Entretiens. Paris: Éditions Amsterdam, 2005.

FOUCAULT, M. A arqueologia do saber. Rio de Janeiro: Forense Universitária, 2004.

FOUCAULT, M. Les rapports de pouvoir passent à l'intérieur des corps. In: FOUCAULT, M. Dits et écrits II, 1976-1988. Paris: Gallimard, 200I. p. 228-236.

LOURO, G. L. Um corpo estranbo. Ensaios sobre sexualidade e teoria queer. Belo Horizonte: Autêntica, 2004.

ROLNIK, S. Toxicômanos de identidade. In: LINS, D. Cultura e subjetividade. Saberes Nômades. Campinas: Papirus, 1997. p.19-24.

ROLNIK, S. Cidadania e alteridade: o psicólogo, o homem da ética e a reinvenção da democracia. In: SPINK, M. J. (Org.). A cidadania em construção uma reflexão transdisciplinar. São Paulo: Cortez, 1994, pp. 157-176.

SILVA, T. T. A produção social da identidade e da diferença. In: SILVA, T. T. (Org.). Identidade e diferença. A perspectiva dos estudos culturais. Petrópolis, RJ: Vozes, 2007. p. 73-IO2. 


\section{Poder psiquiátrico e transgeneridade:}

\section{em torno da verdade diagnóstica}

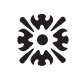

Beatriz Pagliarini Bagagli

Meu texto tenta reunir alguns pensamentos dispersos e iniciais acerca da questão dos processos de subjetivação que estou tentando traçar a partir de algumas leituras de Michel Foucault no que se refere à questão transgênera e psiquiátrica. Isto porque este autor em diversas partes de sua obra se questionou acerca da constituição da subjetividade a partir da própria existência de discursos que pretendem dizer as verdades do sujeito.

Procuro então pensar sobre as práticas que o sujeito tem que estabelecer em relação a ele mesmo no reconhecimento de seu próprio gênero tendo em vista o funcionamento de práticas psiquiátricas que estabelecem o tão famigerado diagnóstico de transexualidade. 
Qual é a dinâmica de poder que se estabelece entre aquele sujeito transgênero que almeja o laudo por intermédio de um psiquiatra? A verdade do diagnóstico é estabelecida através de quais relações entre estes dois sujeitos, como e onde a verdade diagnóstica emerge? De que tipo é esta verdade, quais saberes e práticas médicas e psicológicas são acionadas na constituição desta verdade sobre o gênero e suas patologias?

Trata-se de observar através de quais jogos de verdade o sujeito se reconheceu enquanto portador de uma doença de gênero dentro deste dispositivo médico e quais as possíveis linhas de fuga a este imperativo da verdade sobre o gênero. Compreender como se dá a relação entre esta prática de reconhecimento de si tendo em vista o funcionamento de um poder psiquiátrico que estipula verdades sobre o diagnóstico de disforias de gênero.

Foucault (2006) concebe duas formas distintas de verdade: a verdade enquanto evidência ou acontecimento. A verdade enquanto evidência é aquela que "está em todo lugar e em todo tempo", é vinculada a certa posição filosófico-científica que coloca a aparição da verdade condicionada a uma tecnologia de construção da constatação. A verdade-evidência se põe passível de ser descoberta pressupondo a sua existência prévia e independente ao sujeito que viria conhecê-la; por outro lado, a verdade como acontecimento se dá como um relâmpago ou aparição, ela aponta para a questão da dispersão, da localidade, da contingência própria à verdade. Nessa concepção da verdade como acontecimento, a relação da verdade com o sujeito de conhecimento não é a mesma como ocorre com a verdade -evidência: há implicações distintas do sujeito com a verdade. Na verdade -acontecimento o sujeito não é prévio à descoberta da verdade, tampouco a verdade é prévia ao sujeito: o sujeito de conhecimento se transforma na medida em que conhece a verdade.

Se consideramos que a produção do laudo põe em jogo a busca da verdade de si mesmo, ou seja, trata-se de responder ao imperativo "qual é a sua verdadeira identidade? Qual é a sua verdadeira identidade de gênero? Qual é o seu diagnóstico preciso, verdadeiro?” a distinção entre verdade 
como evidência ou acontecimento é de suma importância para compreender o modo de funcionamento das práticas psiquiátricas e como o poder é exercido nestes espaços das clínicas.

Vamos nos perguntar: a verdade do gênero do indivíduo portador de uma disforia é da ordem da evidência ou do acontecimento? Questões que nos colocam igualmente outras questões: o próprio gênero enquanto objeto a ser conhecido se dá na ordem da apreensão enquanto evidência ou acontecimento? Conhecer seu próprio gênero implica em transformarse e romper com certa evidência subjetiva anterior ou voltar-se para e na fixidez identitária prévia de si?

Poderíamos ver o funcionamento tanto da verdade evidência quanto da verdade acontecimento operando nos discursos médicos sobre a transexualidade. Para Foucault, aliás, não se trata de opor a verdade-acontecimento e a verdade-evidência como sistemas completamente distintos de verdade. Tampouco a psiquiatria pôde se constituir como uma disciplina capaz de construir um saber que diria a verdade da doença mental enquanto mera constatação científica.

Ao contrário, a verdade-evidência, nas palavras do autor, recobriu, colonizou e parasitou a verdade-acontecimento. Com isso se quer dizer que a verdade-evidência, antes de dizer respeito à tão sonhada neutralidade ou objetividade científica, é igualmente produzida através de rituais específicos de poder, se assemelhando neste aspecto com a verdade-acontecimento. A verdade-evidência não seria produzida independentemente do poder, se trata, ao invés, de um certo funcionamento da modalidade de produção de conhecimento em que o poder se mostra como elidido ou dissimulado.

Diria então que há a prevalência no dispositivo da transexualidade, por mais que a psiquiatria não consiga expulsar para fora de seu campo científico a verdade enquanto acontecimento, da verdade do gênero como evidência. Primazia da fixidez em detrimento do descontínuo. Relações de poder entre estes dois sistemas de produção de verdades sobre as identidades de gênero, na tensão entre a constatação e o acontecimento. A psiquiatria não 
conseguiu de fato constatar a verdade da transexualidade inscrita no biológico; se trata, antes de tudo, de uma forma de funcionamento do poder psiquiátrico de dissimular o exercício de seu próprio poder neste domínio especifico que se refere aos transtornos de identidade de gênero.

Arrisco então dizer que a própria ideia de um laudo que ateste a patologia do gênero é profundamente estranha e incompatível à verdade enquanto acontecimento. Um laudo faz justamente isto: atesta uma verdade enquanto evidência científica, fazendo dizer a verdade do sujeito sem mesmo a necessidade do sujeito se implicar na produção desse conhecimento; isto porque a verdade construída pelo laudo é tautológica, ela cria e justifica a si mesma, a verdade do gênero se constitui exterior aos sujeitos, tanto às pessoas transgêneras que demandam terem seus gêneros discursivizados pelo e no diagnóstico quanto ao próprio psiquiatra que escreve o laudo, pois a verdade está no próprio diagnóstico.

Neste regime de verdade, o sujeito trans deve se manter o mais transparente possível entre a sua manifestação da verdade - inscrita na biologia - e sua decifração pelo psiquiatra a fim de se realizar um diagnóstico preciso. A posição do sujeito enquanto afirmada tenta ser anulada ao máximo neste processo, visto que o sujeito deve falar outra voz que a sua própria: uma voz capaz de fazer falar a própria biologia - a evidência científica tem que se mostrar enquanto tal, cristalina - de forma mais transparente possível para o psiquiatra.

Qualquer forma de tomada de posição enquanto sujeito, qualquer coisa que faça remeter ao sujeito será tido então pelo psiquiatra como um empecilho ao seu exercício de diagnóstico. Gênero é presumidamente inscrito na biologia, e para obter a verdade do gênero, é preciso estabelecer uma prática de interrogatório em que a biologia possa falar a disforia do corpo transexual de forma inequívoca.

A própria subjetividade é transformada em falsidade, um terrível véu que impede o acesso à verdade nesta discursividade que patologiza o gênero. Nessas relações, o psiquiatra poderá, em nome da verdade do gênero, 
excluir o sujeito do diagnóstico, imputando a curiosa denominação de "falso transexual".

Isso porque se o sujeito falar sobre seu gênero de outra forma, fugindo da racionalidade diagnóstica, estará sendo excluído deste regime de veridição das técnicas psiquiátricas. A subjetividade aparece como eterna possibilidade do sujeito enganar a si mesmo, pois o sujeito, ao assumir o que há de não todo e não contínuo no gênero na sua própria constituição subjetiva, estará fora dos regimes que produzem a verdade diagnóstica. É como se estivesse se autoiludindo. Se o sujeito não falar a partir das regras que permitem falar a biologia do corpo disfórico ele será tido então como um sujeito "iludido por si mesmo".

O poder psiquiátrico, desta forma, estabelece a própria distinção entre a realidade e a ficção, formas de subjetividade reais e outras ilusórias, distinção entre loucura e normalidade do gênero, tendo como base de sustentação de seu discurso a perspectiva biologista que afirma que há biologia no gênero, e a verdade do gênero é apreendida através da fala da biologia representada no diagnóstico.

A questão que aparece então não é acerca propriamente da verdade, mas do perigo que o sujeito de gênero tem em relação a si mesmo; a psiquiatria se põe então o papel de proteger os indivíduos de si mesmos. Aqui o perigo é do sujeito se reconhecer enquanto travesti, pois a travestilidade é o próprio perigo do gênero, ao fugir da nosologia transexual. Quero dizer: a travestilidade é perigosa na exata medida em que foge da verdade médica.

Se admitimos então que a verdade do gênero está no diagnóstico, qual é a verdade do diagnóstico? Quais práticas e saberes são mobilizados no diagnóstico de transexualidade verdadeira e da transexualidade falsa?

A verdade do diagnóstico se constrói sobretudo através da distinção entre realidade e ficção que me referi acima. Certamente a verdade do diagnóstico de disforia de gênero se mobiliza pelo conceito de transexualidade em detrimento da travestilidade. A travestilidade por vezes acaba sendo simbolizada como a falsa transexualidade pelo discurso psiquiátrico. 
A transexualidade é investida de sentido pelo discurso psiquiátrico e a travestilidade aparece como falta de sentido.

O sentido do gênero, no discurso psiquiátrico, envolve fortemente a construção de coerência de totalidade entre vários elementos que são passíveis de análise: diversos sentimentos, valorações, aparências, performances, desejos dispersos e contínuos dos sujeitos que são postos numa relação de sentido tendo em vista certa utilidade.

O sentido do gênero como "útil”, no diagnóstico, se baseia na coerência de certas normas sociais em relação ao gênero normal. A análise dessa coerência, contudo, não se dissocia das práticas de poder que fazem da cisgeneridade o destino natural dos sujeitos de gênero. A falsa transexualidade apareceria como quebra destas coerências, a falha de um sentido do sexo como um desdobramento óbvio que unisse a evidência da biologia e a evidência social da cisgeneridade.

A falha só se dá pela descontinuidade, por isso é importante acionar a verdade enquanto acontecimento para compreender a especificidade de formas de subjetivação que estabelecem linhas de fuga ao poder psiquiátrico.

O que proponho, frente a um posicionamento transfeminista, é contestar a verdade-diagnóstico que simboliza a travestilidade como falsa transexualidade. Para isso, vamos compreender a travestilidade não em sua negatividade abjeta e delirante, enquanto falta de uma coerência diagnóstica, mas como a própria verdade-acontecimento do gênero.

Eis o erro da psiquiatria: transformar o não todo, não coerente e não contínuo do gênero em falso. Cabe a nós a tarefa de apontar que gênero não é passível de ser posto sob escrutínio por meio de sistema de veridição; não se trata de fazer falar a verdade inscrita na biologia e distinguir então a falsa da verdadeira transexualidade, tampouco de fazer falar a biologia através de um regime de verdade que buscaria produzir a totalidade e coerência de uma disforia de gênero.

A biologia não pode falar, é preciso entender que a subjetivação em relação ao gênero não é a fala transparente da biologia, mas a fala de um 
sujeito de gênero. A biologia não fala, quem fala é o sujeito. $\mathrm{O}$ sujeito, em sua subjetividade, tem sua espessura própria. Não é passível de ser decifrado inequivocamente por um saber psiquiátrico.

A espessura do sujeito não ilude o psiquiatra e a própria pessoa de conhecer a identidade como um véu, ela não é empecilho para a verdade, ao contrário, é condição mesma de seu aparecimento.

O sujeito do gênero que conhece em si a verdade de seu próprio gênero, sob esta perspectiva, tampouco coincidirá consigo mesmo. Conhecer o próprio gênero implica o desconhecimento sucessivo de si resultando em uma destituição subjetiva - há ruptura em relação a si mesmo, pois o sujeito se encontra implicado na sua própria verdade enquanto acontecimento.

\section{Sobre vontades de saber}

Michel Foucault nos mostra que a vontade de conhecer algo não é inocente, tampouco neutra no que se refere às relações de poder. As relações entre o objeto de conhecimento e o sujeito de conhecimento não se dão de forma linear e sob a forma transparente de uma apreensão científica. Nosso objeto, a "identidade de gênero", esta coisa (?) a partir da qual eu suponho ter sido convidada hoje para discursar sobre, não nos permite reducionismos de ordens biológicas, sociológicas ou psicológicas.

Quero dizer, assumo de antemão que "identidade de gênero" não é um mero dado a ser apreendido a partir de conhecimentos que conjuguem a biologia, a sociologia e a psicologia. Não acredito que isto seja possível, pois parte integrante deste objeto a ser conhecido diz respeito à relação do sujeito consigo mesmo (subjetiva) e com outros (intersubjetiva).

Discursar aqui, a partir deste meu lugar, não é também uma tarefa cômoda. Quero dizer: é incomodo discursar sobre questões de identidade de gênero a partir de um lugar de palestrante a um público alvo que presumo estar sedento por conhecer este tema. A imagem que faço de vocês também inclui um sujeito de caráter aberto, minimamente "mente aberta", que de 
livre (e boa) vontade se dispõe a ouvir e aprender. De fato, não quero e não faço questão de pensar que eu esteja falando para bolsonaros ou malafaias!

Se estou presumindo que, a partir deste encontro, iremos poder construir conhecimento (de fato estou assumindo esta prerrogativa), temos que considerar também que a relação que estamos estabelecendo aqui não se resume absolutamente entre o sujeito de conhecimento e um determinado objeto.

Por diversas razões: primeiro que a relação que pretendo estabelecer com vocês se dá através da relação entre sujeitos (e não enquanto meros objetos a serem preenchidos pela minha fala) e o próprio objeto de nosso mútuo interesse - as identidades de gêneros - não se dissociam da própria categoria de sujeito. Temos então que considerar que a relação entre nós eu, Beatriz, que supostamente detenho o conhecimento, vocês plateia um tanto quanto uma massa inerte a "ser preenchida" de conhecimento acerca de nosso objeto de mútuo interesse - estabelecem relações extremamente complexas.

Por isso talvez seja necessário, antes de falar qualquer coisa em relação ao tema que me foi proposto, pensar acerca de certos imaginários que tomamos como dados que orientam os sentidos sobre uma palestra acerca dos lugares que ocupamos, eu enquanto palestrante, vocês enquanto público e, permeando nossas relações, esta presumida vontade de conhecer as "identidades de gênero".

Está presumido que eu, tendo a posse de determinado conhecimento, vou transmiti-lo a vocês, plateia. Eu vou suprir a falta de vocês, vou preencher vocês com informação que vocês muito provavelmente não sabem, vou educar vocês, lhes provir conhecimento e informações completamente inéditas. Aqui a educação por vezes aparece como acréscimo a partir de um espaço vazio - ocupado por vocês - que eu teria o papel de suprir. Nesta perspectiva, o público-ouvinte aparece demasiadamente objetificado assim como o próprio objeto de conhecimento a ser transmitido; temos então que nos atentar criticamente em relação a este imaginário. 
Igualmente não é indiferente o fato de eu ser uma pessoa trans e estar ocupando um espaço privilegiado na construção de conhecimento sobre o tema.

Com isso não estou dizendo que toda relação entre mestre-aluno, palestrante-ouvinte, professor-estudante tem que ser meramente abolida. De fato, para mim, enquanto pessoa trans, poder ocupar este espaço é algo absolutamente necessário e desejado por mim.

O que eu não posso deixar de passar batido, numa fala como essa em que toma este tema "identidade de gênero", é acerca desta vontade de verdade que subjaz todas as nossas posições e falas e que interfere de forma constitutiva no que estamos querendo conhecer.

A relação entre conhecimento e desconhecimento no nosso caso não se resume ao polo "vazio x cheio", "presente $\mathrm{x}$ ausente" ou "conteúdo x ausência de conteúdo". Diria que o desconhecimento acerca das identidades de gênero desviantes, as transgêneras, não se dá meramente pela ausência de determinado conteúdo ou informação; ao contrário, este tipo de desconhecimento se dá justamente pelo excesso de conteúdo e informação. O ódio transfóbico não se dá simplesmente porque falta informação; a transfobia, assim como todo ódio em relação a uma minoria, se dá porque algo foi preenchido excessivamente de sentidos. Sentidos de ódio no caso, mas poderiam ser sentidos de exotificação, colonização e condescendência igualmente.

Partimos de uma excessiva simbolização acerca das identidades de "homens" e "mulheres", todo mundo sabe o que é um gênero de verdade e o que é apenas uma "identidade". Diante de tamanho excesso, fica difícil simbolizar o recorte cis $\mathrm{x}$ trans. Vocês, então, ao invés de me pedirem que lhes diga algo de conteúdo acerca das identidades de gênero, deveriam me orientar muito mais para a deriva, a desconstrução e o questionamento deste excesso de conteúdo e informação que tomamos aprioristicamente acerca do gênero.

O que eu teria então para fornecer a vocês de conhecimento acerca das identidades de gênero? Se vocês esperavam que eu dissecasse as ínfimas 
diferenças e nuances que distinguem travestis, transexuais, transgêneros, cross-dressers, drag-queens e demais outras identidades possíveis e imagináveis, eu sinto em lhes dizer que esta não é minha intenção.

Vamos desconfiar por um momento da máquina de categorizar, levando em consideração que é justamente a excessiva produção de verdades acerca de determinadas categorias que funcionam na exclusão e no desconhecimento que me referi acima. Espero apontar para a possibilidade da deriva, da polissemia, da abertura de sentidos como forma ética de se relacionar com o que está excluído das formas de representação.

E aqui se trata sobretudo de uma educação ao diferente, ao oprimido e ao estigmatizado: o que eu faço com uma travesti, como devo tratá-la, o que devemos conhecer da travestilidade para ser educado(a) com ela, para ser respeitoso(a) com ela, para ser útil em relação aos seus problemas? $\mathrm{O}$ que eu, enquanto acadêmico - vejam só, estou me pegando na equivocidade de presumir um sujeito acadêmico cisgênero - devo saber do tema "identidade de gênero" para que meu conhecimento acadêmico - seja nas áreas médicas, de saúde mental, social - seja útil para esta população marginalizada?

Sem dúvidas existem diversas injunções aqui e elas são absolutamente necessárias. É absolutamente necessário, frente a uma realidade de inúmeras precaridades em relação a serviços básicos de saúde e de extrema exploração econômica e espiritual, os acadêmicos, em suas especialidades de saber, começarem a se posicionarem eticamente diante da realidade dos oprimidos: aqui das travestis, em especial. É preciso que diversos profissionais se interroguem em suas áreas de atuação frente a realidade das travestis: em que medida vocês enquanto classe profissional ou enquanto pessoas que não sofrem das injunções materiais deste grupo oprimido são responsáveis pela perpetuação ou mudança desta realidade? E trata-se também de um questionamento necessário inclusive para mim.

O que os psiquiatras e psicólogos tem a dizer frente a patologização das identidades trans? $\mathrm{O}$ que estes profissionais tem a dizer frente ao poder que lhes são concedidos a legitimarem os gêneros das pessoas trans 
em laudos - o que inclui dar o direito à própria vida? O que vocês, profissionais, têm a dizer do seu próprio poder?

Como eu disse, estabelecer critérios normativos em relação a um laudo de transexualidade é ter o poder de legislar sobre a vida e a morte, já que é a própria vida das pessoas transgêneras que estão a mercê deste controle: seus corpos, suas subjetividades, identidades, enfim, a própria vida é tomada enquanto passível de ser conhecida - leia-se controlada, exercida poder - por meio de um laudo de transexualidade. Legislar também sobre a própria verdade do gênero.

Um laudo tem o poder de traçar destinos na vida de uma pessoa trans. Diante disso, como pode a psiquiatria e psicologia se posicionarem frente a este poder? Pode o poder psiquiátrico e psicológico se mostrar tão elidido a ponto de práticas como a confecção de um laudo passarem a ser vistas como mera constatação de uma verdade científica extraída de um corpo disfórico e inerte?

Neste aspecto, é de suma importância que estes saberes psi problematizem a relação entre sujeito, objeto e conhecimento, o que significa questionar o próprio estatuto da verdade da identidade de gênero que é formulada em um diagnóstico: a relação, enfim, que se estabelece entre dois sujeitos que ocupam espaços distintos (enquanto transgênero e profissional psi) e o objeto a ser conhecido, o próprio gênero do sujeito trans. Este objeto a ser conhecido não é apreendido como mera constatação de um fato que é extraído de um substrato biológico, psicológico ou sociológico, mas é estabelecido através da relação do sujeito consigo mesmo na relação com este profissional psi. Para compreender o funcionamento destes saberes psi temos que nos atentar para relações complexas que se dão de forma inter e intrasubjetivas, perpassadas pelas instituições.

Para compreender então a dinâmica destas relações é preciso, sobretudo, levar em consideração o que é externo a estes saberes tipicamente psíquicos. Quero dizer, em que medida certas injunções jurídicas, burocráticas, sociais e econômicas (enfim, tudo ligado a uma forma de instituição que vá além da clínica) exercem influencia na relação entre profissional psi 
e pessoa trans acerca da construção deste complexo objeto a ser conhecido a partir de si mesmo na mediação com um profissional, sua "identidade de gênero" ou seu "diagnostico".

Partimos de uma realidade em que diversas instâncias exigem o laudo de transexualidade para acessarmos direitos básicos, como mudança de nome nos documentos oficiais, acesso à saúde e validação em diversas esferas sociais que exigem a comprovação que de fato o sujeito em questão tenha um diagnóstico preciso de transexualidade.

Diante deste cenário, não há como afirmar que as pessoas não estejam a priori coagidas por diversas forças a terem seus gêneros legitimados por este saber psicológico e psiquiátrico. $\mathrm{O}$ que as disciplinas como psicologia e psiquiatria têm a fazer não é denegar estas injunções de força, não é encenar uma consulta-diagnóstica que supostamente estaria livre destas terríveis coerções do poder. É preciso que a psiquiatria e psicologia tenham um olhar mais honesto e ético em relação a suas próprias práticas, ao compreender o complexo funcionamento do poder que envolve a formulação de um laudo de transexualidade.

"Descobrir", "conhecer", "atestar" a inconformidade de gênero em um diagnóstico de transexualidade não é a construção de uma constatação neutra. Colocar a transexualidade como verdade a ser descoberta e extraída nos recônditos dos corpos disfóricos, tampouco.

Falamos acerca da despatologização da transgeneridade. Minha intuição me dizia há tempos que este debate tem muito mais a ver com o modo do funcionamento das práticas e saberes psiquiátricos do que meramente a presença e ausência de uma categoria na Classificação Internacional das Doenças (CID) ou no Manual Diagnóstico e Estatístico de Transtornos Mentais (DSM).

Enquanto a psiquiatria e a psicologia não compreenderem o laudo enquanto mero instrumento a ser utilizado pelas pessoas trans, se assim o quiserem, como estratégia de resistência frente a uma realidade precária, não estaremos avançando dentro da psicologia e psiquiatria. $O$ laudo deve proporcionar agência às pessoas transgêneras, e não o contrário, como 
vem representando até agora: medo e apreensão de se encaixar corretamente.

O laudo deve ser esvaziado do seu conteúdo de verdade enquanto constatação de uma doença e ser visto como um instrumento biopolítico. Esse instrumento biopolítico deve estar à disposição daquele sujeito que o laudo atesta. O laudo não deve ser compreendido como resultado de uma tecnologia precisa de veridição e subsequente exclusão entre quem é transexual verdadeiro e de quem é transexual falso.

O laudo deve ser compreendido fora deste sistema de veridição que coloca todo momento sob suspeita a identidade do sujeito; ele não deve ser resultado de uma tecnologia de desvelamento e construção de evidência, mas sim enquanto instrumento a servir ao reconhecimento da autoidentificação de um sujeito.

Laudo enquanto estratégia do poder frente a uma realidade precária se opondo ao laudo enquanto constatação: desta forma vislumbro a possibilidade da psiquiatria e psicologia de estabelecerem uma relação de autocrítica acerca de seus próprios saberes-poderes-verdades.

É nesta direção que penso que temos que seguir quando falamos da discussão, em nossa realidade brasileira, acerca da despatologização da transexualidade. A despatologização não significa, como costumam pejorativamente acusar, falta de acesso a terapias psicológicas ou falta de atendimento à saúde; também não significa a mera exclusão de categorias em manuais diagnósticos.

A despatologização significa a mudança e autocrítica, dentro dos espaços e discursos das clínicas, dos saberes e práticas dos psiquiatras e psicólogos tendo em vista um deslocamento da forma como se encara a relação dos sujeitos com suas identidades de gênero: se deslocando do modelo biomédico de constatação de evidências pretensamente científicas para um modelo ético e politicamente engajado. 


\section{Referências}

FOUCAULT, M. Aula de 23 de janeiro de 1974. In: FOUCAULT, M. O poder psiquiátrico: curso dado no Collège de France (1973-1974). São Paulo: Martins Fontes. 2006

$\frac{248}{\operatorname{cop}}$ 


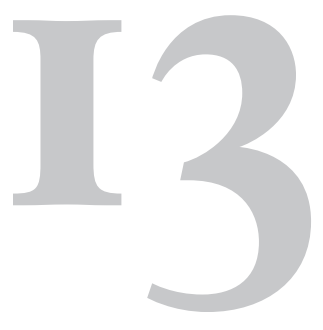

\section{Pensando a cisgeneridade como crítica decolonial}

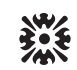

Viviane Vergueiro

Este artigo foi elaborado a partir de minhas colocações na mesa "Moralidades (trans)feministas, famílias e assistencialismos", no dia 27 de maio de 2015 , coordenada por Jaqueline Gomes de Jesus e com as participações queridas de Beatriz Pagliarini Bagagli e Hailey Alves. Acredito ser importante ressaltar o fato de esta ter sido uma das poucas ocasiões em que uma mesa em evento acadêmico é constituída exclusivamente por mulheres trans e transfeministas, esperando que essa ocasião possa ser um aspecto simbólico crítico para se ressaltar a importância das contribuições de pessoas trans e de transfeminismos ao se pensarem questões relativas a diversidades corporais, identidades de gênero e feminismos. 
Fiquei extremamente feliz com a oportunidade viabilizada neste Seminário Enlaçando Sexualidades, compreendendo os convites para compor esta mesa como uma corajosa decisão política, por parte da organização, de promover solidariedade e diálogo com estas questões historicamente invisibilizadas e relegadas a segundo plano em políticas públicas e epistemes acadêmicas. Espero que as reflexões trazidas pela mesa e por este artigo estejam à altura da responsabilidade que nos foi confiada.

No sentido de pensar as contribuições de pessoas trans, travestis e de transfeminismos à teoria e política, inicio este artigo, assim como iniciei minha fala, com um singelo porém fundamental reconhecimento dos ativismos e conhecimentos trans, travestis e gênero-diversos junto aos quais procuro aprender e atuar - tanto os históricos como os contemporâneos. São estes os ativismos e conhecimentos que, em seus processos de resistência e luta, viabilizam a existência dessa e de outras perspectivas transfeministas em espaços acadêmicos, e espero que possamos, enquanto comunidades, fortalecê-los crescentemente para consolidar avanços e ampliar nossas possibilidades de viver bem nestas diversidades.

Também considero necessário reconhecer as redes de afeto e resistência (acadêmicas, ativistas, pessoais) que têm considerado minha voz uma contribuição potencial nestes temas. Em um mundo que odeia corpas não normativas, que interseccionalmente extermina e ojeriza nossas vidas, e que nos precariza amoras e afetos, nosso existir é resistir, parafraseando Jennicet Gutiérrez, ${ }^{1}$ de formas frequentemente bastante literais. Que a intensificação de nossas redes e articulações faça babilônias cissexistas queimarem, e novos cenários decoloniais emergirem. E, aqui, é importante que em processos de autorreflexão estejamos sempre engajadas, enquanto

1 Jennicet, em junho de 2015, interrompeu um discurso do presidente estadunidense Barack Obama com uma denúncia contra a detenção e abuso de pessoas transimigrantes sem documentação, e entre suas colocações políticas está a afirmação "Mi existir es resistir". Para algunas informações adicionais, ver <http://vamosjuntos.org/my-existence-isresistance-an-evening-with-jennicet-gutierrez-the-activist-who-interrupted-obama/>. 
pessoas e coletivas, na re+consideração constante das estratégias e esforços interseccionais que empreendemos.

As ideias centrais que pretendo elaborar neste artigo são as seguintes: (I) definições possíveis do conceito de cisgeneridade, e sua relevância para pensar sobre diversidades corporais e de identidades de gênero; (2) uma proposição de que a cisgeneridade, enquanto perspectiva sobre corpos e identidades de gênero, se constitui como normatividade que organiza moralidades, famílias e também perspectivas assistencialistas, de tutela e sujeição sobre estas diversidades; e (3) um apontamento sobre a necessidade de re+(des)+organizar tal organização normativa, situando cisnormatividades a partir de um entendimento das ciscolonialidades que se estabelecem, interseccionalmente, através de violências institucionalizadas e não institucionalizadas, e buscando caminhos e respostas possíveis para o desmantelamento desta organização.

Para iniciar estas reflexões, gostaria de trazer duas definições importantes para se justificar a relevância do conceito de cisgeneridade. Dos Princípios de Yogyakarta, "princípios sobre a aplicação da legislação internacional de direitos humanos em relação à orientação sexual e identidade de gênero" (ICJ, 2007), trago as definições de orientações sexuais e de identidades de gênero que fundamentarão a proposição conceitual de cisgeneridade.

Sobre as orientações sexuais, os Princípios as definem como fazendo

referência à capacidade de cada pessoa de ter uma profunda atração emocional, afetiva ou sexual por indivíduos de gênero diferente, do mesmo gênero ou de mais de um gênero, assim como ter relações íntimas e sexuais com essas pessoas. (ICJ, 2007)

Neste sentido, cumpre enfatizar que, a partir desta definição, todas as pessoas têm orientações sexuais, sendo a construção de orientação sexual "normal" atrelada às heterossexualidades. Essa é uma compreensão importante, na medida em que o exercício de nomeação da "normalidade" é um processo historicamente situado: a heterossexualidade, enquanto 
conceito, surge a partir de esforços ativistas para questionar a assimetria entre os ditos "desvios sexuais" em relação às sexualidades "normais" e "saudáveis".

Por sua vez, as identidades de gênero podem ser definidas como

[...] a profundamente sentida experiência interna e individual do gênero de cada pessoa, que pode ou não corresponder ao sexo atribuído [imposto] no nascimento, incluindo o senso pessoal do corpo e outras expressões de gênero. (ICJ, 2007)

Similarmente às orientações sexuais, destacamos que todas pessoas têm identidades de gênero, e que estas se constituem complexamente a partir de um referencial de normalidade. A cisgeneridade, conceito sobre o qual dialogaremos a seguir, representaria justamente tal referencial, denotando as corporalidades e identidades de gênero que, em suas características e autoidentificações, estejam alinhadas às ideias de corpos e identidades de gênero "normais", "não transtornados", "biológicos".

Nesse sentido, uma primeira definição para a cisgeneridade seria considerá-la a identidade de gênero daquelas pessoas cuja "experiência interna e individual do gênero" corresponda ao "sexo atribuído no nascimento" a elas. E aqui talvez seja importante uma ressalva sobre os propósitos deste conceito: aqui, não se trata de almejar a criação de uma "identidade cisgênera”, ao menos não no sentido de reproduzir o exercício de diagnóstico e imposição identitária que é colocado diante das comunidades e pessoas trans travestis. Trata-se, sim, de um esforço no sentido de encontrar formas de se referir às normalidades corporais e de identidades de gênero sem recorrer a terminologias que, de uma maneira ou outra, partem da naturalidade ou superioridade cisgênera - como, por exemplo, o uso de termos como "biológico" e "de verdade" para designar pessoas que não sejam trans travestis.

Para além desta equiparação necessária, analisar a cisgeneridade implica também em uma possibilidade de refletir sobre a normalidade e os dispositivos de poder que produzem sua naturalização: uma análise cistêmica 
que nos viabilize cartografias críticas acerca das violências institucionalizadas e não institucionalizadas contra as diversidades corporais e de identidades de gênero. Desses elementos e proposições podemos depreender, portanto, que esse exercício conceitual não guarda relação significativa com algumas críticas realizadas "ao termo cis", das quais destaco duas: (I) a crítica na linha "não sou cis", ou "não sou tão cis assim", e em relação ao "privilégio cis"; (2) a proposição conceitual de cisgeneridade como uma produção de um suposto "binário cis-trans", como uma divisão entre homens e mulheres (respectivamente, óbvio) Ioo\% masculinos e femininas em contraposição às pessoas trans travestis "ontologicamente" subversivas e revolucionárias de gênero.

Dessa forma, a partir de uma perspectiva autoetnográfica transfeminista, defendo a proposição conceitual e analítica da cisgeneridade enquanto crítica decolonial, contrapondo-me a estas duas críticas nos seguintes sentidos: em relação a (I), inicio apontando a colonialidade do saber que se pode depreender de quando consideram que o centro do exercício analítico+político+vivencial sobre cisgeneridade esteja na delimitação identitária de quem sejam as "pessoas cis".

Esta colonialidade do saber (conceito que pensaremos adiante) se expressa não somente a partir da compreensão de que a interpelação da cisgeneridade se constitui como mera consequência lógica do tradicional tratamento dispensado às comunidades e pessoas trans travestis gênero -inconformes - tanto em seu extensivo uso textual de terceiras pessoas quanto na exterioridade discursiva mais ampla destas comunidades e pessoas $^{2}$-, mas "especialmente" na percepção de que circunscrever os diálo-

2 Sobre esta exterioridade discursiva, acredito que algumas das reflexões autoetnográficas em "Humanizando populações cis" e "Autoetnografando populações cis", presentes na dissertação de mestrado que neste momento finalizo, podem trazer elementos relevantes. Uma simples ilustração desta exterioridade pode ser notada no contraste entre pessoas trans travestis e seu "oposto", explícito e implícito, de pessoas "de verdade", "biológicas", "cromossômicas"; a categoria cisgeneridade desestabiliza alguns dos essencialismos e supremacismos que constituem estas oposições historicamente colocadas. 
gos (acadêmicos e feministas, particularmente) sobre cisgeneridade a este 'tema sobre quem são as pessoas cis" configura uma simplificação e subalternização epistemicamente violentas de nossas necessidades e demandas políticas, enquanto comunidades e pessoas. $\mathrm{Na}$ análise da colonialidade cisgênera interseccionalmente situada, portanto, é de fundamental importância pensar sobre as consequências destas violências de invisibilização em nossas vidas, em como estes silêncios e desperdícios temporais de "não sei se sou cis" reverberam - colocando-os em contexto histórico - na legitimação e re+produção dos nossos processos de genocídio (político, sociocultural, existencial, físico).

Por sua vez, a partir do entendimento das utilizações e análises sobre cisgeneridade, genealogicamente associadas a comunidades trans ${ }^{3}$ e aos desenvolvimentos teóricos transfeministas e queer enquanto um exercício de nomeação da normalidade contra a qual nos definem como pessoas "transtornadas mentais" e "imorais", assombra que determinados ceticismos e críticas acerca da categoria analítica de cisgeneridade se devam à suposta "binarização" que essa categoria traria, no sentido de produzir “oposições binárias” entre pessoas cisgêneras ıoo\% normatizadas e pessoas trans travestis I00\% subversivas.

O assombro se deve, particularmente, ao fato de parte destes ceticismos e críticas serem provenientes de um campo de saber dedicado, entre outras coisas, ao uso da categoria heterossexualidade como uma possibilidade crítica de se problematizarem as produções discursivas sobre sexualidades, e um campo que é supostamente alinhado a uma proposta epistemológica crítica de considerar esta dimensão subjetiva sem tomar a heterossexualidade como pressuposto de normalidade ou ideal, nem tampouco como uma homogeneidade binária Ioo\% oposta aos “desvios sexuais”.

3 É importante localizar interseccionalmente estas comunidades: o uso da categoria cis, até onde alcançam as genealogias a que tive acesso, estão bastante associadas a comunidades virtuais (fóruns, por exemplo) entre pessoas trans no contexto estadunidense (trans, aqui, compreendido como um amplo espectro de identidades de gênero inconformes à cisnormatividade), o que indica determinados privilégios de acesso na constituição destes primeiros usos. 
Os estudos queer, assim, nos trazem a necessidade de diálogo sobre o que significa, por um lado, utilizar a categoria de heterossexualidade para refletir teoricamente sobre sexualidades, e de outro, recusar e silenciar a proposição da cisgeneridade para refletir teoricamente sobre identidades de gênero. Enquanto comunidades e pessoas trans travestis, precisamos pensar sobre o que isso significa, em termos de colonialidade do saber e dos limites e possibilidades de transformação sociocultural a partir da academia, e de perspectivas queer e LGBT. Mais além, também sei que não são incomuns as queixas, entre estas comunidades e pessoas, de que muitos projetos e pesquisas feitas conosco a partir desta academia tiveram de nenhum a muito pouco impacto sobre nossas vidas; então, acredito que fica a urgência da reflexão e historicização necessárias.

Ainda pensando na categoria heterossexualidade, a proposição de cisgeneridade dialoga profundamente com reflexões dos estudos queer, na medida em que estes refletem sobre as complexidades das heterossexualidades e também das sexualidades não normativas, apontando tanto os desvios da heteronormatividade presentes em experiências heterossexuais quanto os alinhamentos normativos presentes entre comunidades e pessoas não hetero. Isto significa que, na análise sobre cisgeneridade, a suposta reprodução de um binário "cis-trans" (o ponto 2 de crítica) se configura como uma simplificação grosseira, já que estes entendimentos complexificam as análises acerca da produção das violências normativas, constituindo-se como fonte importante de conhecimento que devemos, em parte, aos estudos queer.

A limitação destas críticas queer à cisgeneridade reside, portanto, na colonialidade do saber que dificulta a percepção desta categoria analítica como produto, diálogo e aprendizado das comunidades e pesquisadoras trans travestis com perspectivas teóricas pós-estruturalistas, ${ }^{4}$ bem como uma ferramenta útil de desestabilização das posições inferiorizadas em que

\footnotetext{
4 Talvez não tenham os vocabulário para tais discussões teóricas, enquanto comunidades e pessoas trans travestis, como certa vez inferiu um professor relacionado aos estudos queer.
} 
estamos, em termos políticos, institucionais e existenciais. A cisgeneridade, nomeada e analisada, e sendo utilizada como uma ferramenta conceitual para demonstrar a profunda, ampla e generalizada invisibilização e marginalidade contra pessoas e comunidades trans travestis em espaços demais mundo afora. Como uma forma, enfim, de identificar ciscolonialidades e as exigências políticas necessárias e estratégicas diante destas violências.

Sendo assim, espero sinceramente que as necessárias conversas sobre cisgeneridade na academia e nos processos políticos caminhem criticamente para além destes "não sou tão cis assim”, "que onda é essa de privilégio cis", e "não devemos segregar as pessoas de forma tão binária". Torna-se importante, nesse sentido, compreender a genealogia do pensamento sobre identidades de gênero, um caminho que não se restringe às ciências da saúde e que remonta a um esforço intelectual e político, protagonizado pelas comunidades e ativismos trans travestis, de existência discursiva para além de nossa contraposição a uma suposta normalidade mental ou alinhamento biopsíquico.

A disputa política da cisgeneridade, enquanto disputa pela linguagem, constitui-se como um esforço para superar as assimetrias presentes na construção discursiva das identidades de gênero não cisgêneras (trans, travestis, entre outras). A partir de uma caracterização da transexualidade apresentada por Márcia Arán (2006), nos é trazida uma consideração interessante sobre estas assimetrias: "[a] transexualidade é considerada um fenômeno complexo. Em linhas gerais, caracteriza-se pelo sentimento intenso de não-pertencimento ao sexo anatômico, sem a manifestação de distúrbios delirantes e sem bases orgânicas”.

Poderíamos fazer diversos apontamentos sobre esta caracterização, porém destaco a ideia de que haveria, entre pessoas (pacientes?) transexuais, este "sentimento intenso de não-pertencimento ao sexo anatômico". Muitas pessoas considerariam este sentimento de nãopertencimento como algo "ilusório", "mentalmente transtornado"; ao propor a cisgeneridade como desnaturalização de determinadas identidades de gênero, fazemos um convite à consideração dos elementos (verdadeiros? reais? mental- 
mente sãos?) que constituiriam um "sentimento intenso de pertencimento ao sexo anatômico". A partir da colocação a seguir, seríamos talvez "diferentemente iludidas", nós pessoas cisgêneras, trans, travestis? As certezas de quais pessoas valem mais, nos jogos socioculturais de gênero?

Do nosso ponto de vista, é fato que a certeza quanto ao pertencimento ao gênero oposto [...] se repete no cotidiano do atendimento a pacientes transexuais. Entretanto, esta mesma ilusão não difere muito da ilusão de uma essência 'masculina' ou 'feminina' nos homens e mulheres considerados 'normais'. (ARÁN, 2006, p. 6o)

Questionar estas assimetrias, assim, constitui-se como parte importante da proposição analítica de cisgeneridade, no sentido de tornar mais evidentes as proximidades entre as ilusões nos processos de autoafirmação de identidades de gênero (desnaturalizando, portanto, a cisgeneridade). Como destaca Mauro Cabral, ativista e pesquisador trans*/inter*, "[p]or que parece que as mulheres e homens [cisgêneros] têm gênero e as pessoas trans* têm identidade de gênero?” (BENTO, 20II) Destacar a cisgeneridade também implica, por sua vez, em colocar em pauta nossas ausências na produção de saberes acadêmicos enquanto agentes, fato que convive com crescentes presenças trans travestis enquanto objeto e tema de estudos nestes espaços: estas ausências e presenças marginais podem impedir e dificultar que demandas destas comunidades emerjam na academia.

Sendo assim, procedo em direção a uma proposição analítica da cisgeneridade que parte da perspectiva de que não se trata meramente de uma proposição teórico-analítica, mas de um posicionamento epistêmico+político. Esta definição é apoiada sobre três eixos: pré-discursividade, binariedade, permanência. Falamos sobre estes eixos a seguir.

A pré-discursividade, primeiramente, pode ser caracterizada como o entendimento sociocultural - historicamente normativo - de que seja possível definir sexos e gêneros de seres a partir de critérios objetivos e de determinadas características corporais, independentemente de como 
sejam suas autopercepções ou das posições e contextos interseccionais e socioculturais em que tais seres estejam localizadas.

O momento a partir do qual uma definição sobre as "materialidades sexuadas/generificadas" se torna pré-discursivamente factível é, nesse sentido, o momento em que se compreende (a partir de critérios normativos) que estes corpos trazem certos sinais fidiscursiva que o possam definir inequivocamente entre "macho"ou“fêmea". Tais definições são tidas como necessárias por uma variedade de razões sociais, ainda que, como aponta Julie Greenberg (2006), estas definições não somente são muito mais complexas e menos objetivas do que o senso comum talvez possa imaginar, mas também que elas se alinham a compreensões normativas sobre possibilidades corporais, desejos e práticas sexuais e reprodutivas.

Sendo assim, para analisar a pré-discursividade como característica necessária à conceituação de cisgeneridade, um conceito central a ser desconstruído e problematizado é o conceito de "sexo". Este conceito "é comumente utilizado para se referir ao status de uma pessoa enquanto homem ou mulher, com base em fatores biológicos", ainda que "o aspecto biológico que determina o sexo de uma pessoa não tenha sido legal ou medicamente determinado" (GREENBERG, 2006, p. 52) e que "nossas corpas [sejam] demasiado complexas para fornecer respostas inequívocas sobre diferença sexual”. (FAUSTO-STERLING, 2000, p. 4) Dessa maneira, torna-se fundamental, portanto, notar como alguns conceitos como a de "sexo biológico" - têm na sua própria naturalização - em oposição ao gênero "cultural" - uma maneira de produção da cisgeneridade enquanto normatividade. A partir de Butler (2003, p. 25, grifo do autora), esta produção das categorias "sexo" e "gênero"é problematizada:

\footnotetext{
que o gênero não está para a cultura como o sexo para a natureza; ele também é o meio discursivo/cultural pelo qual a 'natureza sexuada' ou 'um sexo natural' é produzido e estabelecido como 'pré-discursivo', anterior à cultura, uma superfície politicamente neutra sobre a qual age a cultura.
} 
Ou seja: "colocar a dualidade do sexo num domínio pré-discursivo é uma das maneiras pelas quais a estabilidade interna e a estrutura binária do sexo são eficazmente asseguradas" (ibidem). A necessidade cistêmica de defender a categoria de "sexo" corresponde, assim, à defesa da "naturalidade", da "materialidade”verificável da pré-discursividade da cisgeneridade, que é também a defesa de determinadas leituras e valores ocidentais e eurocêntricos (ver MIGNOLO, 2008).

Em relação ao eixo da binariedade, outra importante característica da cisgeneridade, podemos refletir a seu respeito ao levar em consideração que a leitura normativa sobre os corpos se considera capaz de, através de critérios supostamente objetivos, determinar sexos-gêneros, sendo também uma leitura atravessada pela ideia de que estes corpos, se "normais", terão estes gêneros definidos a partir de duas, e somente duas, alternativas: macho/homem e fêmea/mulher.

Neste sentido, parece relevante enfatizar que tal maneira binária de interpretar as diversidades corporais e de identidades de gênero opera a partir de "processos de naturalização de diferenças" que encobre relações de poder que as organizam. (LEITE JÚNIOR, 20II, p. 199) Esse encobrimento de relações de poder dificulta a percepção de que o "dimorfismo sexual" dito científico apresenta um alinhamento a "formas euro-americanas de compreender como o mundo funciona" que "dependem significativamente do uso de dualismos - pares opostos de conceitos, objetos e [c] istemas de crença”. (FAUSTO-STERLING, 2000, p. 20-2I) Todos corpos e gêneros têm uma história, e a binariedade como uma normatividade sociocultural eurocêntrica define e restringe os destinos de muitos deles pelo mundo.

Nesse sentido, “a noção de que pode haver uma 'verdade' do sexo [...] é produzida precisamente pelas práticas reguladoras que geram identidades coerentes por via de uma matriz de normas de gênero coerentes" (BUTLER, 2003), interseccionalmente atrelada a outros vetores de normatização. Pode-se notar, por exemplo, como "a heterossexualização do desejo requer e institui a produção de oposições discriminadas e assimé- 
tricas entre 'feminino' e 'masculino', em que estes são compreendidos como atributos expressivos de 'macho' e de 'fêmea”. Pensar possibilidades decoloniais diante de cisnormatividades implica em proposições críticas de "matrizes rivais e subversivas de desordem do gênero", bem como na problematização e desnaturalização desta mesma "matriz de inteligibilidade" (BUTLER, 2003, p. 38-39) cisnormativa binária.

O terceiro elemento nesta breve tentativa de definição da cisgeneridade é a premissa de que corpos "normais", "ideais", "congruentes" ou "padrão" apresentam uma certa coerência fisiológica e psicológica em termos de seus pertencimentos a uma ou outra categoria de "sexo biológico", e que tal coerência se manifeste nas expressões e identificações vistas como “adequadas” para cada corpo de maneira consistente através da vida de uma pessoa.

Dessa forma, descentralizar a cisgeneridade como definidora das possibilidades legítimas de gênero deve, também, ser um processo que questione a premissa de permanência das identidades de gênero em suas relações e diálogos com suas formações corporais, uma premissa que, em se produzindo como normatividade, estabelece restrições e violações de direitos significativos às diversidades corporais e de identidades de gênero.

Em um exemplo trazido por Thiago Coacci (2013, p. 53), é notável como, em discursos jurídicos, "é a fixidez do sexo a principal razão para se negar a alteração dos documentos dos/as transexuais”. Entre os posicionamentos deste campo de saber, percepções que explicitam como a ideia de permanência permeia compreensões sobre diversidades corporais e de identidades de gênero:

Quem nasceu com conformação genérica do sexo masculino será sempre integrante do sexo masculino; e quem nasce com a conformação genética do sexo feminino será sempre desse sexo um integrante. É uma verdade imutável; ao menos até hoje. [...] No caso, qualquer pessoa que tenha se submetido ou venha a se submeter à referida cirurgia, continuará integrante do sexo que a natureza lhe concedeu. 
Em outro posicionamento, reforça-se argumento semelhante: "Seus órgãos internos são de um homem, situação inalterável, perene”. (COACCI, 2013, p. 55) O contraste entre estes argumentos surgidos em discursos jurídicos e percepções que compreendam o gênero como performatividade são explícitos, como se pode notar em Butler (2007, p. 273-274, tradução nossa, grifo do autor):

O gênero não deve ser interpretado como uma identidade estável ou um lugar em que se assenta a capacidade de ação e de onde resultam diversos atos, senão como uma identidade fragilmente constituída no tempo, instituída em um espaço exterior mediante uma reiteração estilizada de atos. [...] Esta formulação distancia a concepção de gênero de um modelo substancial de identidade e a coloca em um terreno que requere uma concepção de gênero como temporalidade social constituída. É significativo que, se o gênero se institui mediante atos que são internamente descontínuos, então a aparência de substância é precisamente isso, uma identidade construída, uma realização performativa.

Trata-se, nesse sentido, de notar os diálogos entre um cistema judiciário para o qual a "verdade imutável" do gênero - da cisgeneridade - se produz por "conformações genéticas" e "genitálias”, com projetos colonialistas em que esta suposta verdade se constitui como dispositivo de poder que extermina, explora, monitora e restringe as diversidades corporais e de identidades de gênero em diferentes culturas e sociedades. Perceber o gênero como performativo não somente abala a naturalização da ideia de permanência cisnormativa, como também situa nossas construções performativas em relação a nossas inserções socioculturais, às interpretações que existam, nestes contextos, sobre corpos e pertencimentos de gênero.

A partir destes três elementos que constituiriam a cisgeneridade como conceito, podemos então pensar derivações que trazem, potencialmente, contribuições à compreensão das normatividades que atravessam as diversidades corporais e de identidades de gênero: algumas delas, a serem pensadas neste texto, são cisnormatividade, cissexismo e ciscolonialidade 
- para além das corruptelas intencionais, como cistema. Antes, porém, acredito ser importante enfatizar o caráter interseccional deste conceito e suas derivações, tanto no sentido de situar as diversidades corporais e de identidades de gênero como vetores interseccionais entrelaçados a vários outros, quanto no sentido de tornar mais complexas as reflexões, por exemplo, sobre as comunidades e pessoas trans travestis. Guilherme Gomes Ferreira (20I4, p. 4I), em seu trabalho Travestis e prisões: a experiência social e a materialidade do sexo e do gênero sob o lusco-fusco do cárcere, faz uma consideração crítica que me parece apontar nesta direção, a da necessidade de pensar estas diversidades a partir de lentes interseccionais, com particular ênfase em classe:
[A] realidade social onde é produzida a identidade travesti [...] é fru- to, entre outras coisas, das condições materiais de vida e da sua inser- ção numa classe social determinada. Não se está aqui dizendo que a identidade travesti é generalizadamente um produto da pobreza, ou que a pobreza define uma identidade de gênero como essa.

A apresentação destas complexidades interseccionais traz consigo um abalo nas premissas cisnormativas, especialmente na medida em que desestabiliza simplificações estereotípicas sobre comunidades e pessoas trans travestis, entre outras. Ao pensarmos sobre caminhos decoloniais, falaremos sobre a importância da autocrítica constante que implique em reflexões interseccionais.

Os estereótipos e simplificações sobre comunidades e pessoas trans travestis podem ser analisados como consequências de processos de naturalização da cisgeneridade. Durante minha apresentação no Seminário Enlaçando Sexualidades, comentei sobre algumas frases que ilustrariam um pouco destes processos:

\footnotetext{
"esta pessoa é biologicamente homem" / "nasceu homem"

"era ela, virou ele" / "homens, mulheres e trans"

"nossa, parece mulher de verdade"
} 


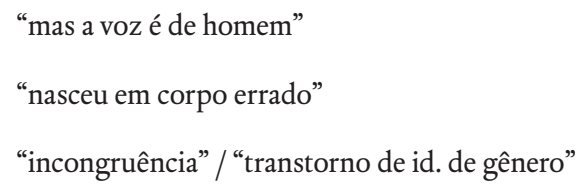

Note-se como estas colocações tanto idealizam um ou outro eixo da cisgeneridade como "natural" e "biológico", quanto os tomam como a base "ideal" para definir vivências tidas como "fora" da cisgeneridade como transtornadas, doentes, inferiores. São estes processos normativos que constituem, em níveis institucionais e não institucionais, forças cistêmicas como o cissexismo e cisnormatividade. Em relação ao primeiro, podemos trazer uma definição feita por Erica Lennon e Brian J. Mistler (20I4, tradução nossa) no primeiro número da publicação Transgender Studies Quarterly, sobre "cisgenerismo” (cisgenderism, no original)s: "esta ideologia fundamenta e perpetua a crença de que identidades e expressões cisgêneras são mais valorizadas [legítimas] que as trans*, criando um [c] istema indissociável de poder e privilégios relacionados.”

Dessa forma, a proposição conceitual de cisgeneridade se localiza para além de enfatizar o caráter de "ideologia cultural" que configura a cisgeneridade (e muito mais distante ainda, evidentemente, de um exercício de nomeação de "quem é cis e quem não é"). É uma proposição nos que incita, também, a desestabilizarmos hegemonias epistêmicas, legitimando e valorizando a necessidade dos saberes desde "olhares oposicionais", parafraseando Bellhooks (I992).

Nomear o cissexismo enquanto violência, portanto, constitui-se como possibilidade de linguagem e como consequência e produto destes olhares oposicionais, cujos saberes estiveram em cada um dos trukes e doces e mandingas e estratégias, e pouco a pouco (interseccionalmente) também

\footnotetext{
${ }^{5}$ Utilizamos cissexismo neste texto, devido à sua popularidade de uso nos contextos trans travestis brasileiros em relação ao uso de cisgenerismo, o termo que é apresentado por estas pessoas autoras. Acredito, entretanto, que em termos analíticos é possível pensá-los enquanto sinônimos.
} 
se vão fazendo presentes na teorização formal (não sem tensionamentos e silêncios de apagamento). $\mathrm{O}$ cissexismo, assim, compreendido em suas dinâmicas de violência e normatização institucionalizadas e inseridas em contextos socioculturais: relacionadas, desta forma, a conceitos historicamente utilizados nas lutas ativistas, como "homofobia" e "transfobia".

As considerações sobre cisnormatividade, por sua vez, procuram enfatizar que os processos cisnormativos produzem consequências mais amplas que aquelas violências direcionadas a comunidades e pessoas trans travestis: nesse sentido, os seus efeitos não se restringem a estas comunidades e pessoas marginalizadas, mas normatizam e monitoram vidas cisgêneras também (de distintas maneiras). Poderíamos pensar em como as normas de gênero afetam vivências cisgêneras, no sentido das regulações sobre suas expressões de gênero e das limitações colocadas à sua autonomia corporal (especialmente em relação a mulheres cisgêneras), entre diversos outros dispositivos cisnormativos.

A ideia de cisnormatividade pode ser alinhada à de heteronormatividade; segundo Cathy Cohen (1997, p. 440), a heteronormatividade se constitui pelas "práticas localizadas e instituições centralizadas que legitimam e privilegiam a heterossexualidade e relacionamentos heterossexuais como fundamentais e "naturais". A cisnormatividade estaria alinhada à heteronormatividade na medida em que se constitui pelas práticas e instituições que legitimam e privilegiam a cisgeneridade como corporalidades e identidades de gênero naturais e mentalmente saudáveis; tais práticas organizam, entre outros fatores, moralidades, ideais de família e Estado, bem como as possibilidades políticas de pensarmos as diversidades corporais e de identidades de gênero.

Outra ideia que, a partir da cisgeneridade, pode proporcionar reflexões críticas acerca das diversidades corporais e de identidades de gênero é a de ciscolonialidade. A organização cisnormativa de ideias morais e familiares é indissociável dos históricos projetos coloniais europeus, cristãos, branco-supremacistas, projetos que instaura(ra)m diferentes formas de colonialidade contra diferenças étnico-raciais, cosmogônicas e de 
interpretações socioculturais sobre corpos e identidades de gênero. Daí a importância de atrelar os entendimentos e análises sobre cisnormatividade às colonialidades históricas que ainda hoje fundamentam determinadas normatividades. Para considerarmos a ciscolonialidade, uma reflexão conceitual sobre colonialidade e colonialismo feita por Eduardo Restrepo e Axel Rojas (20IO, p. I5) também pode nos ser útil:

O colonialismo se refere ao processo e aos aparatos de domínio político e militar que se exercem para garantir a exploração do trabalho e das riquezas das colônias em benefício do colonizador. [...] A colonialidade é um fenômeno histórico muito mais complexo que se estende até nosso presente, e que se refere a um padrão de poder que opera através da naturalização de hierarquias territoriais, raciais, culturais e epistêmicas.

Destacar as ciscolonialidades e suas relações com as normatividades em relação a corpos e identidades de gênero nos instiga a re+pensar como os projetos coloniais não estiveram circunscritos à exploração econômica e política das colônias, tendo como sua parte constituinte a idealização de perspectivas socioculturais eurocêntricas, cristãs e racistas sobre corpos e identidades de gênero. Ademais, nos desafia à construção de genealogias que objetivem analisar como estas colonialidades históricas persistem até hoje, através dos assassinatos cotidianos de pessoas trans travestis, entre tantos outros exemplos.

Um breve trecho da Crónica del Perú, de Pedro de Cieza de León (I553), citado em entrevista de Giuseppe Campuzano (2013), pode ilustrar bem estas linhas de continuidade violentas:

A verdade é que, geralmente, entre os serranos e yungas o demônio introduziu este vício disfarçado como santidade. E é que, em cada templo, o adoratório principal tem um homem ou dois, ou mais [...], os quais andam vestidos como mulheres desde que eram garotos, e falavam como tais, e em suas maneiras, trajes e tudo mais imitavam as mulheres. [...] Isto eu sei por ter castigado dois índios de sua majestade. 
Os castigos exercidos contra os "dois índios de sua majestade" eram parte integrante de inúmeras estratégias coloniais de dominação contra moralidades e famílias que eram estranhas à dita "civilização" europeia, como aponta Rita Laura Segato (2010):

\begin{abstract}
Povos indígenas [...], assim como uma quantidade de povos nativos norte-americanos e das primeiras nações canadenses, além de todos grupos religiosos afro-americanos, incluem linguagens e contemplam práticas 'transgêneras' estabilizadas, casamentos entre pessoas que o ocidente entende como 'de mesmo sexo', e outras transitividades de gênero bloqueadas pelo [c]istema de gênero absolutamente engessado da modernidade colonial.
\end{abstract}

Através dos processos de extermínio, invisibilização e marginalização destas perspectivas não ocidentais sobre corpos e identidades de gênero, foram se constituindo formas institucionais e não institucionais de ciscolonialidade que seguem como dispositivos necessários à continuidade destes processos. No âmbito deste breve artigo, centralizo minha análise sobre a colonialidade do saber que permeia as diversidades corporais e de identidades de gênero, e em algumas demandas políticas necessárias ao seu enfrentamento e desmantelamento.

Como se expressa esta ciscolonialidade do saber? Alguns elementos frequentes nas epistemologias hegemônicas a respeito de diversidades corporais e de identidades de gênero ilustram um pouco desta forma de colonialidade. Entre eles, consideremos as preocupações acadêmicas em torno de definir se pessoas trans travestis são subversivas ou reprodutoras de normas de gênero, a construção de uma "linha do tempo do universo trans" em que pessoas trans travestis parecem existir somente a partir de desenvolvimentos nas ciências da saúde (o conceito de "transexualidade" sendo especialmente atrelado às possibilidades tecnológicas de procedimentos cirúrgicos), e as presenças marginalizadas e inexistentes de pessoas trans travestis em ambientes acadêmicos, onde é muito mais provável que existamos enquanto campo e objetos de estudo do que como pessoas 
pesquisadoras, algo que repercute sobre o tipo e qualidade de conhecimento que é produzido a respeito destes temas.

Um dos caminhos de enfrentamento a esta forma de colonialidade que se desdobra em vários problemas é estabelecer processos de re+escrita e des+aprendizados críticos, legitimar e valorizar os conhecimentos específicos provenientes de nossas comunidades, particularmente nas suas intersecções. No sentido da produção de conhecimentos sobre as diversidades corporais e de identidades de gênero, isso implica em um esforço constante de re+escrita e des+aprendizado de colonialidades condescendentes e inferiorizantes que nos excluíram, historicamente, da possibilidade de produzir conhecimentos válidos sem intermediações de "especialistas", e no enfrentamento efetivo das violências que nos impedem e dificultam o acesso a recursos educacionais. Quando contrapomos nossas experiências complexas e interseccionalmente localizadas contra as epistemologias dominantes que simplificam e condescendem nossas comunidades e pessoas trans travestis, construímos fissuras na ciscolonialidade que, espero, possam explicitar e denunciar as funções morais por detrás das supostas objetividade e neutralidade das ciências, permitindo a constituição de outros modelos de gênero (ver SINGER, 2006).

Para viabilizar este caminho, é imprescindível notar as complexidades subjetivas trans* (travestis, trans, transexuais, não binárias, entre outras), e as dificuldades envolvidas em nos agenciarmos; interrogar-se sobre que tipos de proposta epistemológica nos animam, enquanto comunidades e pessoas; e questionar nossas ausências marcantes enquanto referenciais teóricos (particularmente, nos debates relacionados a questões transtravestis e de trabalho sexual). Alguns esforços decoloniais têm sido desenvolvidos neste sentido, e incluem:

I. Pensar a intersecionalidade como autorreflexividade crítica, no sentido de re+pensarmos, re+des+construirmos e des+aprendermos nossas perspectivas políticas a partir de aprendizados e complexificações das leituras sobre o mundo; 
2. demandar formas de monitoramento comunitário de projetos realizados junto a populações trans, com contrapartidas dialogadas e avaliação dos impactos sobre as comunidades;

3. dialogar sobre a importância do desenvolvimento de metodologias de pesquisa "para validar a interpretação de dados de pesquisa" como "componente crucial de qualquer prática sociológica reflexiva” (NAMASTE, 2000, p. 267), e em especial quando envolvam participantes trans travestis;

4. lutar pela autonomização dos saberes, cuidados e comunidades entre as diversidades corporais e de identidades de gênero, diante de um cistema educacional cissexista que as expulsa e violenta como regra.

Gosto de pensar que estes esforços, mesmo quando aparentemente intransponíveis, possam contribuir para a construção de movimentos que centralizem sua atenção e demandas políticas nas pessoas que mais necessitam de apoio, possam assegurar que os investimentos em projetos acadêmicos ligados às populações trans travestis tenham impacto efetivo sobre estas comunidades e sejam produções dialéticas de conhecimento, e que eles nos incitem constantemente a formar comunidades onde autonomizemos nossas epistemologias e processos de conhecer, nossos auto+cuidados, afetos e sexualidades, e nossas autopercepções sobre corpos e identidades de gênero, para muito além de paradigmas ocidentalizados, eurocêntricos, patologizantes e supremacistas.

Que nossos esforços decoloniais culminem no desmantelamento de cistemascissexistas, cisnormativos e ciscolonialistas, em alianças e solidariedades interseccionais com outros esforços necessários às transformações socioculturais em prol das diversidades corporais e de identidades de gênero. 


\section{Referências}

ALDRICH, R. (Ed.). Gay Life and Culture: A World History. New York: Universe, 2006.

ARÁN, M. A transexualidade e a gramática normativa do sistema sexo-gênero. Ágora, Rio de Janeiro, v. 9, n. I, p. 49-63, 2006. Disponível em: <http://www. scielo.br/scielo.php?script=sci_arttext\&pid=SI516-I4982006000100004\&ln $\mathrm{g}=$ en\&nrm=iso>.

BENTO, B. Política da diferença: feminismos e transexualidades.. In: COLLING, L. (ed.). Stonewall 40 + o que no Brasil?. Salvador: Edufba, 20II. p. 79-IIO.

BUTLER, J. Problemas de gênero: feminismo e subversão da identidade. Rio de Janeiro: Civilização Brasileira, 2003. Tradução de Renato Aguiar.

BUTLER, J. El género en disputa: El feminismo y lasubversión de laidentidad. Barcelona: EdicionesPaidós Ibérica, 2007. Tradução de Maria AntoniaMuñoz. CAMPUZANO, G. Giuseppe Campuzano y El Museo Travesti del Peru (Entrevista con Lawrence La Fountain-Stokes). Instituto Hemisférico de Performance y Política, 2013. Disponível em:< http://hemisphericinstitute.org/hemi/es/ campuzano-entrevista> .

COACCI, T. "Eu tenho um amo implacável: a natureza das coisas": discursos jurídicos acerca das transexualidades no Tribunal de Justiça de Minas Gerais (1989-2010). Revista Diálogo, Canoas, n. 24, p. 45-62, Dezembro 2013. Disponível em: <http://www.revistas.unilasalle.edu.br/index.php/Dialogo/ article/view/1304/993>.

COHEN, C. Punks, Bulldaggers, and Welfare Queens - The Radical Potential of Queer Politics? GLQ, v. 3, p. 437-465, 1997.

FAUSTO-STERLING, A. Sexing the body: Gender politics and the construction of sexuality. Nova Iorque: Basic Books, 200o. ISBN 0-465-07714-5.

FERREIRA, G. G. Travestis e prisões : a experiência social e a materialidade do sexo e do gênero sob o lusco-fusco do cárcere. Dissertação (Mestrado em Serviço Social) - Faculdade de Serviço Social, Pontifícia Universidade Católica do Rio Grande do Sul, Porto Alegre, 20I4. Disponível em: <http://repositorio.pucrs.br/dspace/ bitstream/I0923/5660/1/00045406I-Texto+Completo-o.pdf> . 
GREENBERG, J.. The Roads Less Traveled: The Problem with Binary Sex Categories. In: CURRAH, PAISLEY, JUANG, MINTER (Ed.). Transgender Rights. Minneapolis, Minnesota: University of Minnesota Press, 2006, p. 5I-73.

HOOKS, bell. Black Looks: Race and Representation. Boston, Massachusetts: South End Press, 1992. Principles - Principles on the application of international buman rights law in relation to sexual orientation and gender identity. 2007. Disponível em: http://www. yogyakartaprinciples.org>. Acesso em: 15 out. 2014.

LEITE JÚNIOR, J. Nossos corpos também mudam: a invenção das categorias "travesti" e "transexual" no discurso científico. São Paulo: Annablume: FAPESP, 2011.

LENNON, E.; MISTLER, B. J. Cisgenderism. Transgender Studies Quarterly. Postposttransexual: Key Concepts for a 21st Century Transgender Studies, v. I, n. I-2, p. 63-64, 20I4. Disponível em: <http://tsq.dukejournals.org/ content $/ \mathrm{r} / \mathrm{I}-2 / 26$.full.pdf $>$.

MIGNOLO, Walter. Desobediência Epistêmica: A opção descolonial e o significado de identidade em política. Cadernos de Letras da UFF - Dossiê: Literatura, língua e identidade, Rio de Janeiro, n. 34, p. 287-324, 2008. Disponível em: <http://www.uff.br/cadernosdeletrasuff/34/traducao.pdf>.

NAMASTE, V. K. Invisible lives: the erasure of transsexual and transgendered people. Chicago, Illinois: The University of Chicago Press, 2000.

RESTREPO, E.; ROJAS, A. Inflexióndecolonial: fuentes, conceptosy cuestionamientos. Popayán, Colombia: Editorial Universidad del Cauca, 2010.

SEGATO, R. L. Género y colonialidad: en busca de claves de lectura y de unvocabulario estratégico descolonial. [s. 1], [s. n], 2010.

SINGER, T. Benjamin. From the Medical Gaze to Sublime Mutations: the Ethics of (Re)Viewing Non-Normative Body Images. In: STRYKER, S.; WHITTLE, S. (Ed.). The Transgender Studies Reader, p. 6oI-620. Nova Iorque: Routledge, 2006. p. 60I-620. 


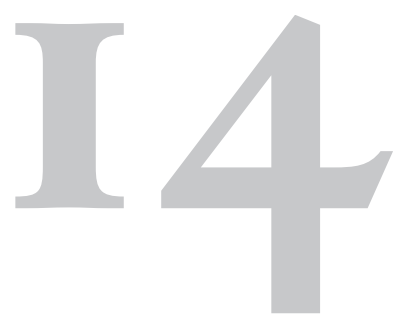

\section{Moralidades:}

\section{quando a heterogênese ética se mostra criadora e livre de juízos de valor bipolares}

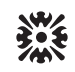

Dante Augusto Galeffi

\section{Introdução}

Com o intuito de corresponder ao tema da mesa "Moralidades", e visando contribuir de algum modo para o aprofundamento da questão moral no que diz respeito a todos os seres humanos em suas relações eco-sócio-mentais (relações ambientais, sociais e mentais), inicio interrogando a moralidade em sua modelagem homogênea para fazer aparecer o âmbito plural e heterogêneo da moralidade contemporânea, pós-moderna, transmoderna. Mostra-se imperante o uso plural das 
instâncias valorativas do comportamento humano, fazendo-se necessário aprender a compreender a moral em suas moralidades em construção no mundo democrático em seu projeto utópico e heterotópico simultaneamente, para além dos modelos de moral fechada dominantes. Para tanto, faço uma pergunta para iniciar uma provocação interrogante: o que se considera em geral moralidade em contraposição à imoralidade e de que modo se está construindo novas moralidades frutos da criatividade e liberdade partilhada humana?

Usando do recurso da etimologia como pretexto para o desenvolvimento do argumento intencionado, moralidade é a qualidade do que é moral. É um termo derivado do latim mos, moris, costume, hábito, designa a maneira de agir pelo uso, pela repetição, pelo habitual; delimita o comportamento axiológico do ser humano em suas relações sociais e de poder, sua produção de valores como condutas habituais nas relações intra e intersubjetivas. $\mathrm{O}$ termo indica também o caráter de um indivíduo, caracterizado pelo seu humor, capricho, vontade, fantasia, maneira, modo de ser, de aparecer, de comportar-se. $\mathrm{O}$ termo se opõe ao que pertence ao âmbito legislativo no sentido de uma "obrigação determinada por decreto". No latim o termo "mores", plural de moris, designava o conjunto de traços do caráter de um indivíduo, de um povo, de uma sociedade, de uma época. Daí a palavra moral apontar para que é relativo aos costumes de um indivíduo, aos caracteres de um povo, de uma sociedade, de uma época histórica etc. A palavra, portanto, significa "caráter" no sentido de uma marca distintiva, caracterizando modos de ser como comportamentos habituais de indivíduos e sociedades.

A moralidade, então, é uma condição existencial da humanidade em suas realizações singulares e únicas. É, assim, inerente ao que se diz como ser humano em seus modos de ser no mundo com outros. Todo ser humano é por condição um ser moral: existe enquanto se reconhece com os outros em suas relações de afeto e de poder. A moralidade, então, não diz respeito em sua condição prévia a nenhuma forma ideal de comportamento humano e sim ao fato de todo ser humano concreto e vivente 
comportar-se segundo padrões axiológicos decorrentes de sua inserção em determinada sociedade com suas crenças e padrões morais instituídos. Independente do modo de produção de sentido moral, todo ser humano é um ser de costumes e crenças, sentimentos e emoções, regras e normas, razões e princípios, irrazões e suprarrazões. $\mathrm{Na}$ moralidade o racional e o irracional se entrelaçam. Pode-se dizer com Bergson (2004) que o hábito ou a moralidade humana ocupa uma função similar à do instinto nas outras sociedades dos seres vivos. Entretanto, o que leva uma livre consciência, desatrelada do mundo da necessidade, a agir? Será esta instância que leva à ação individual puramente racional, ou também carrega o gérmen indelével do instinto, do irracional, do mecânico?

Respondendo às questões, seguindo Bergson (2004), há um senso de obrigação em toda moralidade, e a essência de tal "obrigação moral” não é o dever racional, e sim a pressão social decorrente das regras instituídas em uma dada sociedade e reforçadas pelo hábito. Citando Bergson (2004, p. 59):

[...] diremos que a natureza, dispondo a espécie humana ao longo do curso da evolução, a quis sociável, como quis as sociedades de formigas e de abelhas; mas uma vez que estava presente a inteligência, a manutenção da vida social devia ser confiada a um mecanismo quase inteligente, na medida em que cada peça podia ser remodelada pela inteligência humana, instintivo, porém, na medida em que o homem não podia, sem deixar de ser um homem, rejeitar o conjunto das peças e já não aceitar um mecanismo conservador. $\mathrm{O}$ instinto cedia provisoriamente lugar a um sistema de hábitos, cada um dos quais se tornava contingente, sendo necessária apenas a sua convergência no sentido da conservação da sociedade, e trazendo esta necessidade o instinto consigo. A necessidade do todo, sentida através da contingência das partes, é aquilo a que chamamos a obrigação moral em geral; as partes, aliás, apenas são contingentes aos olhos da sociedade; para o indivíduo, no qual a sociedade inculca hábitos, a parte é necessária do mesmo modo que o todo. [...] Teria a natureza previsto o enorme desenvolvimento e a complexidade indefinida de sociedades como as nossas? 
Temos aqui um recorte compreensivo da moralidade como uma "obrigação moral” configurada socialmente. A sociabilidade humana produz a moralidade habitual. Mas nas sociedades humanas os programas podem ser reprogramados, as coisas dadas podem ser ressignificadas, o instituído pode ser destituído e se fazer de novo instituinte. Não há, portanto, modelos morais a serem mecanicamente imitados e sim o reconhecimento da natureza moral dos indivíduos sociais humanos. A moralidade, assim, assinala o modo de ser no mundo com outros de cada indivíduo de sociedades concretas e não uma ideia monológica de boa conduta.

Então, se a moralidade humana nada tem a ver com formas morais ideais e monológicas, é preciso compreender a moral humana pela linha de desenvolvimento de seus casos concretos e históricos. As formas morais tradicionais são aquelas vigentes em determinada sociedade humana, pois a moral aparece antes como uma "obrigação social" do que como uma decisão do indivíduo diante dos imperativos de sua vida. Mas aparecem também as formas fechadas e formas abertas de moralidade, o que permite distinguir regimes morais distintos no desenvolvimento humano em geral.

Falando das duas formas de moral, a fechada e a aberta, Bergson (2004, p. 63) esclarece:

Entre a primeira moral e a segunda há, portanto, toda a distância que vai do repouso ao movimento. A primeira supõe-se imutável. Se muda, esquece imediatamente que mudou ou não confessa a mudança. A forma que apresenta seja em que momento for pretende ser a forma definitiva. Mas a outra é um ímpeto, uma exigência de movimento; é mobilidade em princípio. Seria assim que provocaria - seria apenas assim que poderia até mesmo começar por definir - a sua superioridade. Se nos dermos a primeira, não poderemos fazer sair dela a segunda, do mesmo modo que não poderemos extrair o movimento de uma ou de várias posições de um móbil. Pelo contrário, o movimento envolve a imobilidade, sendo cada posição atravessada pelo móbil concebida, e até mesmo percebida como uma paragem virtual. Mas não há necessidade de uma demonstração em 
regra: a superioridade é vivida antes de ser representada, e não poderia, aliás, ser a seguir demonstrada se não começasse por ser sentida.

É, pois, o sentimento moral o que interessa. Um sentimento que pode ser fechado ou aberto e que funda humanamente toda ação valorativa. O importante é, então, reconhecer a diferença entre um regime de moral insensível às mudanças vivas e um regime de moral transformativa, que pode alcançar o âmbito da humanidade como organismo em transformação continuada. Esta constatação favorece a compreensão das moralidades como regimes abertos aos fluxos e refluxos do existir factual. Cabe, então, tratar das "moralidades" em uma perspectiva radical de apropriação e vivência libertadora das representações morais racionalizadas e fechadas, porque não esta em causa julgar o comportamento moral de quem quer que seja, e sim o de reconhecer que de um jeito ou de outro todo ser humano se comporta moralmente. E como temos diante a abertura da moral aberta caberia interrogar sobre o seu sentido mais próprio e apropriado.

\section{Moralidades em questão: a mudança de paradigma ético-estético em curso}

Apontei para o fato de ser a moralidade um sentimento mais do que uma racionalização discursiva. Ora, valores morais são construções históricas e dependentes de circunstâncias específicas da vida das sociedades que os criou. Valores morais variam de cultura para cultura e não são figuras de linguagem, pois determinam a ação humana em toda a sua extensão e intensidade. Assim, concordando com a compreensão de Bergson, que também encontra ressonância em David Hume ao pressupor a moralidade sendo determinada pelo sentimento e definindo a virtude "como qualquer açãoou qualidade mental que comunica ao espectador um sentimento agradável de aprovação; e o vício como o seu contrário”. (HUME, 2004, p. 372, grifo do autor) 
Ora, na visada apresentada o que importa compreender não diz respeito ao campo das representações morais sociais e sim ao fato que a moralidade é perpassada pelo sentimento de agrado e de desagrado. Hume identifica duas formas de sentimento moral: os agradáveis e os desagradáveis. Os agradáveis são os sentimentos virtuosos e os desagradáveis indicam o vício. Entretanto, como reconhecer a diferença entre sentimentos agradáveis e sentimentos viciosos? Como julgar o bem moral tomando o seu contrário como negação?

A moralidade agora se encontra implicada com os regimes de signos de seus agentes e pacientes, seus usuários e partidários. E são muitas as formas de realização de "sentimentos agradáveis" e de "sentimentos viciosos”. Assim, a definição de Hume é demasiadamente genérica para servir como definidor dos sentimentos morais universais. A realidade moral é aqui recortada pelo sentimento de agrado e de desagrado e não por uma métrica racional definidora do bem e do mal. Mesmo assim, como definir universalmente o bem e o mal sem cair vítima do antropocentrismo radical que a tudo reduz ao âmbito perceptivo do sujeito humano?

Significa também compreender a moral como doutrina do dever monocórdio a partir de sua característica de "obrigação moral”, o que é uma questão a ser sempre interpretada a partir do comportamento de indivíduos membros de uma sociedade histórica produtora de sua própria escala de valores, seus modos de julgamento moral, seus dogmas e preceitos. Assim, a oportunidade de usar o plural "moralidades" para tratar de um tema tão abrangente e polêmico, me leva a pontuar a importância de se usar o critério da multiplicidade como predisposição para a investigação das moralidades humanas em movimento transformativo ético e estético simultaneamente.

Está-se diante de um horizonte polilógico, que é também uma abertura para as formas poli-eróticas de relacionamento, compreendendo-se o Eros como o impulso vital de mais-vida, indo além da sexualidade sem negá-la. Neste aspecto as moralidades são tantas quantas são as pessoas humanas e suas circunstâncias ambientais, sociais e mentais. Desse modo, 
a ideia de uma moralidade universal única esbarra no abismo da multiplicidade heterogenética do mundo da vida e dos seres humanos viventes e suas realizações singulares socializadas.

As moralidades se mostram em inumeráveis direções e sentidos. Mas, porque se associa a moralidade ao dever ou "obrigação social”? O que é certo e o que é errado no agir moral dos seres humanos em suas diferenças radicais? Haveria, por ventura, uma objetividade moral racional, tão clara quanto distinta em sua precisão absoluta?

As moralidades, então, oportunizam o olhar da diversidade, da heterogênese individual e social dos seres humanos concretos. É preciso, então, deixar de lado a crença em uma moralidade objetiva e focar a atenção nas moralidades em suas legítimas formas de ser no mundo com outros. E aqui uma questão importante aparece e diz respeito à relação entre a moralidade e a religiosidade. Muitas vezes confundidas, a moralidade e a religiosidade, o valor moral e o valor religioso visam metas diferentes. Mas o valor religioso é um valor necessariamente moral, ao passo que o valor moral não é necessariamente religioso. Significa que é preciso desatrelar as moralidades dos imperativos da religiosidade instituída, para que não se perca de vista que o que se mira é o ato de apropriação da moralidade como multiplicidade heterogenética. O que também implica na saída da consciência humana dos umbrais do medo e da discórdia afetiva. Isso requer a superação da aceitação passiva de preceitos morais indiscutíveis, porque as moralidades requisitam investigação e suspeita, compreensão e partilhamento, diálogo e enfrentamento. As moralidades requisitam, sobretudo, o ato amoroso em si mesmo, o que indica a elevação do espírito humano para o mais desejável estado de compartilhamento na passagem do tempo, compartilhamento alegre e feliz. Seres humanos, talvez toda a natureza, só se realizam no pleno regozijo vivente. Uma moral alegre se torna ética do cuidado triético.

Quando a moralidade comum é desvinculada dos imperativos da religião estática produtora da moral fechada passa a se configurar pragmaticamente como disposição para deixar o outro ser o caminho do seu desejo, 
porque já deixou ser para si mesmo o caminho do próprio desejo. Tem-se aí o sustentáculo da moralidade vital, que atende ao imperativo do sentimento e não de uma razão objetiva absoluta que quer moldar os corpos e as almas à sua imagem e semelhança. Uma modelagem que impede a gênese da individuação própria e apropriada "criando" a servidão involuntária e voluntária como princípio ontológico único. Mas a moralidade aberta interrompe o ciclo da submissão ontológica, porque nela fala mais alto o sentimento de plena realização e regozijo lúcido no ato de amar além das polaridades regimentais.

Em geral, é comum identificar-se a moral como âmbito da "coerção", do controle, do temor, do medo, da punição, da lei e da ordem implacável. E porque se constata a presença de regimes morais fechados e abertos ao longo do tempo histórico das múltiplas sociedades humanas espalhadas pela Terra, é preciso construir conexões que liguem os diversos pontos ao movimento maior que tudo reúne e tudo separa em igual medida no âmbito do devir-ser humanidade. Há também a moral pregada por povos dominantes em determinado tempo, como é o caso do Ocidente, para o qual a moral é um tecido de muitos fios e filiações grego-romanas e judaico-cristãs, que em determinado momento da história próxima se torna a moral hegemônica marcada pela ideia de uma natureza binária: masculino e feminino, céu e terra, forte e fraco, racional e irracional etc.

Ora, quais são os limites existenciais do ser humano? Como afirmar a segurança de algo que não se encontra acabado e sim em movimento transformativo perpétuo?

De qualquer modo, o ser humano é produtor de valores que são o seu acervo imaterial e material no âmbito dos quais vive a sua vida. A moralidade é um imaterial que vive na materialidade da vida, vive na alimentação, digestão, assimilação e transformação/metamorfose/morte do que vive. E enfim, qual seria o motivo para se limitar previamente o âmbito do comportamento moral dos seres humanos ao cumprimento de valores de conduta coercitivos e absolutos? 
Aqui fica evidente como é preciso olhar a questão da moralidade pelo viés da ética para que se possa ultrapassar o limiar da coerção social (coletiva, impessoal, suprapessoal) do dever-ser alienado e subordinado à ordem absoluta externa, que não dá ao indivíduo o direito de poder-ser diferente em relação ao prescrito imperativamente na lei soberana e opressora binariamente constituída: ou o bem, ou o mal! Sim, porque, o que é o bem e como distingui-lo do mal? Quem dá e qual é a medida de "bem" e de "mal" universal?

\section{O giro ético pós-moderno ou transmoderno: além de bem e de mal como realização do amor universal unido na diversidade e na diferença}

A moralidade humana nasce antes da instituição religiosa, porque todo animal vive em ciclos, é um ser vivo, e o ser humano é um ser vivo que vive de alma no conhecimento que o faz ser-sendo/ser-devindo. Associada à religiosidade por razões históricas evidentes, a moralidade humana não pode ser reduzida às generalidades racionais homogêneas. E diante da diversidade cultural e espiritual das sociedades humanas de todos os tempos, seria impróprio, incorreto, injusto falar de "moralidade" a partir de um modelo de conduta fechado e monológico, universal e absoluto, pois toda moralidade atende ao âmbito do existir humano em seu contexto cosmológico e ao imperativo da vida em seu impulso desejante de ser sempre mais-vida.

Também porque os seres humanos evoluíram das formas morais coercitivas e fundamentalistas, para formas morais em que realiza sua liberdade ontológica fundamental: aquela de se tornar aquilo que seu desejo é! Ora, o desejo! Qual desejo? O que é desejante no desejo?

Para dizer do desejo e o seu sentido positivo ou negativo, tudo depende do regime moral no qual se está imerso, e toda moral humana é construída, inventada, instituída historicamente. Assim, para tratar do giro ético e estético da moral na contemporaneidade posso falar em duas moralidades 
coexistentes. Uma moralidade fundada no medo psicológico e uma moralidade fundada na plena escolha além do bem e do mal. Quero enfatizar que "além do bem e do mal" não prescreve nenhuma medida do bem e do mal e nem aceita nenhuma medida para a moralidade como sentimento virtuoso em seu sentido positivo e vicioso em seu sentido negativo. Entretanto, há algo ainda comum entre o positivo e o negativo, entre a virtude e o vício. Esse algo permanece o sentimento de satisfação e o sentimento de insatisfação como partes diferentes indissociáveis: um não é sem o outro, assim como só se pode ver o que se apresenta nos limites do claro-escuro que configura a percepção visual.

Toco no âmbito da formação ética dos indivíduos humanos sociais, na ultrapassagem dos umbrais da servidão involuntária e voluntária. Daí a importância da ética e da política na vida das sociedades contemporâneas que constituem a via da sustentabilidade triética: ambiental, social e mental. E se há países democráticos e não democráticos, os democráticos têm o dever de cumprir o acordo político constituído para regular e orientar a sociedade em seus processos vitais. Os estados democráticos são laicos por princípio, o que significa dizer que não se intrometem na moralidade religiosa e doméstica de ninguém, pois sua regulação moral é aquela de garantir condições plenas de existência social para todos os membros de sua constelação e redondezas sem exceção.

É a partir do exercício pleno de escolha individual inalienável que se pode falar em moralidades como campo da ação humana para a realização de seus meios e fins práticos e espirituais. E se o direito à liberdade de cada um ser o que é fica garantido nos regimes democráticos, torna-se imperante o acolhimento das diferenças de comportamento moral, na medida em que atendam ao princípio de mais-vida e mais-plenitude-vivente. Ou seja, há também "imoralidades" que merecem consideração densa.

No giro ético pós-moderno ou transmoderno abre-se o campo radical da liberdade partilhada e do cuidado triético incorporado ao mundo da vida. Trata-se de uma ética da libertação que abre ao ser humano a apren- 
dizagem de sua própria invenção renovada, a partir do que é mais antigo. E como afirma Enrique Dussel em sua Ética da Libertação:

A ética da libertação não quer aparecer como novidade. Quer aparecer como uma atualização de uma tradição milenar, pisoteada pelo cinismo do capitalismo globalizador, que pretende o máximo da ciência e da razão, sendo na verdade uma decadência ética, irracional e insensível à dor das vítimas. (DUSSEL, 20I2, p. 649)

Então, o giro pós-moderno/transmoderno da ética realiza a saída da exclusão e do descaso com o Outro a partir da diferença pensada como diferença. Vítimas são todos os que sofrem opressão e violência física e simbólica da parte dos opressores. E aqui a "imoralidade" se mostra como o que atenta contra a vida em suas formas singulares de ser. Imoral é tudo o que não ama o viver e o morrer. Pois viver é também morrer, e morrer é viver da morte que faz reviver para remorrer vivendo: neguentropia entrópica. Em uma ética da libertação o que importa é realizar o amor à vida vivente tendo presente que todo ser humano pode tornar-se plenamente o seu Outro: o caminho libertador. A alteridade liberta da opressão monológica: seja cada um o seu desvelamento único. Pois é imoral atentar contra a vida do Outro, o estrangeiro, o desconhecido, o "bárbaro". Todo preconceito é imoral como expressão de um sentimento de inveja. Porque a inveja é um "menos" da moralidade que em seu "mais" aspira à ética da diferença. Todo "menos" é desvio do caminho ético da libertação. É diante da grandeza desconhecida da diferença como diferença que toda ética é possível em seu agir libertador.

Pensar, então, as moralidades usando-se o critério da plena realização ontológica de cada singularidade é afirmar a diferença como o inesperado que sempre se espera, pois quem não sabe esperar o inesperado, como alguma vez irá encontrá-lo? Assim, quem não espera o Outro nunca poderá acolhê-lo em sua diferença radical. O próprio Dussel buscou inspiração para a sua Ética da Libertação no mais antigo texto crítico encontrado no Egito, que já revela o princípio ético que depois será o fio condutor do 


\section{cristianismo: a acolhida do estrangeiro, do Outro em suas necessidades vitais. Transcrevo aqui passagens de Dussel que apontam a antiguidade da ética da libertação em um texto egípcio:}

282

$\overline{\mathrm{F}}$

Trata-se de um conjunto de textos dispersos que, com ordem diferente, eram colocados junto aos mortos em papiros, para que pudessem 'lembrar' seus atos em vida no momento do 'Juízo Final' de Osíris. Este, depois de ser coroado como príncipe regional (talvez fosse originariamente um personagem histórico), é assassinado por seu irmão Seth, que esquarteja seu corpo e o reparte por diversos lugares, também no Rio Nilo (sua cabeça repousava em Abydos). Ísis recolhe as partes de Osíris, e Anubis o reúne mumificando-o. Seth tenta também matar seu filho Hórus, filho de Ísis, que era a esposa do próprio Seth. Hórus vence o pai (como um novo Édipo) e herda o reino de Osíris. Enquanto isso, Osíris ressuscitou no reino do além. Portanto, é o primeiro ressuscitado e seu protótipo, a quem os que desejam ressuscitar devem invocar. [...] a ressurreição se universaliza a todos os habitantes, mas igualmente as exigências éticas que constam no Livro dos mortos. O ka (a consciência ética absolutamente individual que tem memória e responsabilidade de seus atos), a consciência ético-prática, é o componente central do ser pessoal (junto com outros quatro). Trata-se de um dos mitos éticos mais determinantes da história universal. Cada sujeito individual, em vida e depois da morte sempre individual, tem a experiência ética de realizar as suas obras à luz do 'Juízo de Osíris' (com 'autoconsciência' explícita, já que 'se vê visto' a partir dos olhos de um juiz onisciente, incorruptível, interior e perfeito). A 'vida' (Ankbem egípcio) é dada individualmente pelos deuses a cada ser humano e mantida eternamente no caso do morto merecer ressuscitar por suas boas obras. Todos os deuses levam em sua mão direita a $A n k b$, o sinal da vida (uma espécie de cruz com um pegador através do qual os deuses metem sua mão).

Desejamos só indicar um elemento das tantas riquezas éticas destes textos e em relação ao argumento central de toda esta Ética da libertação. Trata-se do capítulo I25 do indicado livro que desejamos comentar. Este longo capítulo é o relato da presença do que morreu 
na grande Sala de Maat (a lei do universo), onde é julgado o 'Osíris N.' (o morto com nome próprio) para nele encontrar ou não os méritos para ressuscitar. $\mathrm{O}$ capítulo começa, depois da apresentação do que vai ser julgado, com as famosas declarações de inocência ('Não cometi maldade contra os seres humanos. Não maltratei as pessoas...’). Num momento central do texto podemos ler os seguintes critérios éticos, que o morto com pretensão de ressurreição proclama publicamente na grande Sala de Maat:

Satisfiz o deus cumprindo o que desejava. [I] Dei pão ao faminto, [2] água ao sedento, [3] vesti o que estava nu e [4] uma barca ao náufrago.

E os deuses personalizando o morto pergunta-lhe: 'quem és tu me dizem, qual é teu nome? me perguntam'. Isto nos indica o profundo conceito da individualidade pessoal da eticidade egípcia, que o pensamento semita herdará, mas não o grego (com a sua imortalidade universal da alma), e através dos semitas passará para os judeus, cristãos, mulçumanos e modernos. (DUSSEL, 20I2, p. 647)

Essa longa citação aponta para um fator fundamental na compreensão da ética transmoderna: o Outro como o Igual na Diferença.

É, assim, de uma ética da alteridade que dá voz e força aos oprimidos, excluidos, diferentes, que as moralidades emergentes ganham corpo e alma. Está em causa uma qualidade humana sublime, que consiste no acolhimento do estrangeiro, do marginal, do esquecido em sua diferença e em seu poder-ser mais próprio e apropriado. O argumento de Dussel em relação à ética da libertação é certeiro e ressoante com o seguinte: sem amor ao diferente, marginal, oprimido não há libertação possível. E no julgamento feito no Templo da morte o que é pesado na balança é o coração daquele que morreu e agora é avaliado em seus atos e realizações. É o "coração" que é pesado e não suas intelecções computantes e/ou cogitantes. A ética da alteridade faz revelar-se o amor incondicional à vida vivida, vivente $\mathrm{e}$ por viver além de "bem" e de "mal": além do excesso e da privação, além da polarização binária. 
É, então, curioso como a ética da alteridade se resuma na atitude acolhedora do diferente em sua diferença. Assim, a ética pós-moderna e transmoderna em construção é o ultrapassamento de toda malquerença em relação ao que deve ser cuidado com a própria vida: a responsabilidade por si mesmo, a partir da qual se pode abarcar a compaixão universal pelos oprimidos e excluídos do poder-ser mais próprio e apropriado. Isso se alia a uma estética da alteridade que é o modo de aparecer da aparência em sua beleza incomparável.

\section{Considerações inconclusivas: moralidades são signos de diferentes formas de ser-mais}

O princípio moral da vida é sempre o de ser-mais, ser-além do já estabelecido. A natureza em sua exuberância criadora é amoral. Neste âmbito, o que é imoral atenta contra a vida plena, ao princípio do pleno gozo do viver plenamente. $\mathrm{O}$ imoral, assim, é o que nega o princípio do impulso vital da liberdade ontológica do Outro, seja pela violência física ou simbólica.

Imoral é julgar a vida dos outros como se fosse a nossa, porque cada vida é única e com suas próprias circunstâncias e tendências. A humanidade caminha para formas morais além de bem e de mal, por necessidade vital, pois está em movimento a evolução espiritual da espécie e sua saída da lógica binária patriarcal, hierarquizante, excludente.

Assim, a moralidade necessária para a criação humana aponta para o quer-bem a todas as formas de vida e a todos os modos humanos de seguir aprendendo a transformar-se. Pois tudo o que vive é impermanente e se transforma sem cessar. Mesmo as identidades fixas tendem a mudar a partir de circunstâncias diferenciadas e inusitadas. As moralidades, pois, apontam para a pluralidade de modos de sernomundo em que é preciso atentar para o impulso desejante que a tudo movimenta como combustível vital.

A moralidade fechada dá lugar às moralidades abertas. A ideia de homem no singular dá passagem para o plural: seres humanos. A cultura no singular se faz culturas e muitas. $\mathrm{O}$ indivíduo moral no singular se torna 
indivíduos morais, quer dizer, indivíduos que não negam o princípio vital de seus corpos desejantes de maisvida.

Relativismo? Chamar a moral de morais, relativismo moral? E por que não? Que medo nos possui? Medo de Deus?

Mas Deus não tem nada a ver com a moral do chicote, nem com a moral dos exércitos. $\mathrm{O}$ âmbito do amor divino não tem circunscrições, não tem preconceitos de nenhuma espécie, senão não seria divino. Divino é apenas o que ama incondicionalmente. E o que ama incondicionalmente, ama incondicionalmente: não escolhe entre as suas crias os que serão premiados e os que serão castigados pelos seus atos imorais. É a própria consciência de cada um que cuida de fazer a justiça como lei inexorável: nada escapa do julgamento autoconsciente de cada ser em sua singularidade.

Imoral é querer ser a razão do mundo sem nem ao menos conhecer-se em profundidade. Pois tudo está em tudo. O que hoje está cheio, amanhã estará vazio, o que hoje está embaixo, amanhã estará por cima. Tudo flui! Bem e mal são partes de um mesmo âmbito comum, no qual virtuosos e proscritos são o mesmo! Dizem respeito ao que vive e quer chegar a ser o que é como ser em devir.

Moralidades só entram em conflito quando há imbecis que querem falar pela divindade e se sentem premiados por tomarem o partido do divino, como se o divino pudesse ser partido, dividido, loteado. Moralidades dizem da pluralidade de modos de realização da saga humana em sua incansável busca de superação e transcendência.

Sendo maisvida cada um se faz moral no sentido superlativo do sermais. Mas para isto é preciso fazer-se livre de toda e qualquer opressão simbólica, o que exige uma coragem extraordinária, pois só os que se libertam das amarras do medo psicológico e da danação simbólica podem gozar do dom de partilhar da vida transformante amante da vida abundante e da justiça do "coração". Porque sem amor ninguém é nada e sem acolhimento da diferença como diferença não há ética e nem estética criadora do livre. 


\section{Referências}

BERGSON, H. As duas fontes da moral e da religião.Coimbra: Almedina, 2005.

DUSSEL, E. Ética da libertação.Na idade da globalização e da exclusão. 4. ed. Petrópolis, RJ: Vozes, 2012.

HUME. D. Investigações sobre o entendimento bumano e sobre os princípios da moral. 


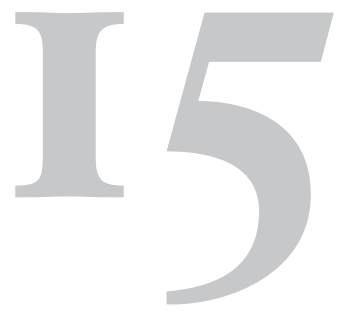

\title{
Gabriela Leite - histórias de uma puta feminista
}

\author{
䓵 \\ Letícia Cardoso Barreto \\ Claudia Mayorga
}

\section{Introdução}

Sempre acreditei e sonhei com o movimento transpondo barreiras e atingindo a sociedade inteira, inteirinha. Sempre acreditei que o movimento de putas não poderia nunca ser babaca, tipo politicamente correto. Queria e quero um movimento revolucionário, recuperando inclusive o sentido revolucionário do ser revolucionário. Uma organização revolucionária sempre tem que se lembrar que seu alvo não é fazer com que seus partidários escutem as convincentes palestras de líderes especialistas, mas conseguir fazê-los falar por si mesmos, 
para que alcancem, ou pelo menos se esforcem por alcançar, o lugar da participação política. Quando minhas amigas putas estavam lá desfilando, lindas e altivas, sem vergonha de ser putas, elas estavam falando por si mesmas e sendo políticas, extremamente políticas e revolucionárias. ${ }^{\text {(LEITE, 2005, p. I6) }}$

$\mathrm{O}$ artigo aqui apresentado se origina de uma homenagem a Gabriela Leite, militante do movimento de prostitutas, prestada durante o IV Seminário Enlaçando Sexualidades, realizado em Salvador, Bahia, em maio de 2015. Nesse momento, consideramos ser essencial homenagear a ativista, falecida em 2013 e que, apesar de sua grande luta por direitos das mulheres prostitutas, frequentemente não é reconhecida como feminista. No supracitado evento, apresentamos um compilado de trechos de vídeos protagonizados por Gabriela ao longo de sua vida que resumiam aspectos importantes de sua trajetória de vida e de luta (BARRETO; MAYORGA, 2015). ${ }^{2}$ Neste artigo, destacamos alguns pontos da trajetória pessoal e política de Gabriela Leite com intuito de explicitar alguns dos legados que essa puta feminista deixou para a luta pelos direitos humanos das mulheres prostitutas.

\section{A prostituição nos eixos: breve apresentação do debate}

Antes de passarmos à discussão de pontos que consideramos que se tornaram importantes na trajetória pessoal e política de Gabriela Leite, bem como do movimento organizado de prostitutas no Brasil, se torna essencial contextualizar o debate, evidenciando a forma como as percepções e

\footnotetext{
${ }^{1}$ Gabriela Leite em sua coluna no Jornal Beijo da Rua.

2 No IV Enlaçando Sexualidades, na ocasião da homenagem a Gabriela Leite, foi também lançado o Prêmio Gabriela Leite, com objetivo de homenagear nomes que contribuíram/ contribuem para o campo de estudos e ativismo feminista no Brasil. A primeira homenageada foi a pesquisadora baiana Suely Aldir Messeder, criadora do encontro Enlaçando Sexualidades, atuante no campo de estudos da sexualidade, gênero e raça.
} 
intervenções em relação à prostituição têm sido pensadas a partir de alguns eixos centrais. No contexto brasileiro, é impossível compreender as questões políticas acerca da prostituição, sem mencionar a trajetória de ativismo de Gabriela Leite. A identificação desses eixos revela o quanto o debate sobre prostituição é marcado por controvérsias e divergências indicando um campo permanente de disputas acerca dos sentidos sobre a prostituição, com efeitos políticos distintos.

Nossos estudos sobre a prostituição nos levam a considerar que esta tem sido pensada a partir de três eixos principais, que se fundamentam na forma como se percebe a prostituição e se age com relação a ela. (BARRETO 2015; MAYORGA 20I2, 20II) Reiteramos que estes meios remetem principalmente à prostituição feminina cis, não necessariamente havendo formas semelhantes de se refletir sobre a trans $^{3}$ ou masculina. A proposta se baseia nos quatro modelos propostos pela socióloga holandesa Marjan Wijers, que fundamentam diferentes regimes legais (WIJERS, 2004), com alterações, já que propomos três eixos centrais, unindo dois dos apresentados por Wijers - abolicionista e proibicionista. Estes eixos não são apenas teóricos, mas envolvem também a práxis frente ao fenômeno. Para Wijers, no modelo proibicionista, a prostituta é vista como delinquente, sendo penalizada, junto com as outras pessoas que atuam no meio. No abolicionista, como vítima a ser libertada e conscientizada, enquanto os demais envolvidos devem ser penalizados. No regulamentarista, a prostituição é considerada mal social, mas sua erradicação é vista como impossível, devendo, portanto, ser controlada, protegendo a sociedade e assegurando a moral, a decência e a saúde. No modelo laboral, a prostituta é considerada mulher trabalhadora, cujo trabalho deve ser regulamentado por legislação laboral e civil comuns. É o único regime que não visa

\footnotetext{
3 Jaqueline Gomes de Jesus propõe, no Guia técnico sobre pessoas transexuais, travestis e demais transgêneros, para formadores de opinião (JESUS, 2012), que todas as pessoas podem ser consideradas cisgêneras ou transgêneras, sendo as primeiras (cis) aquelas que se identificam com o gênero que foi atribuído ao nascerem, as segundas (trans) são não cisgêneros, pois não se identificam com o que Ihes foi atribuído.
} 
a controlar e suprimir a prostituição e que é fruto de discussões com o movimento de prostitutas. (WIJERS, 2004)

\section{Suprimir a prostituição: eixo proibicionista/abolicionista}

O primeiro eixo teórico identificado seria o proibicionista/abolicionista, em que localizam-se aquelas concepções que fundamentam práticas que visam eliminar a prostituição. Em termos de regimes legais, equivaleria ao proibicionista e ao abolicionista, lembrando que o primeiro criminaliza a atividade, bem como as envolvidas, e o segundo também, mas salvaguardando as vítimas (prostitutas). Optamos pela união dos eixos por considerar que em ambos são adotadas posturas e ações que condizem com a supressão da atividade, vista como forma de violência, submissão feminina, exploração, crime.

As abolicionistas estadunidenses Rebecca Whisnat e Christine Stark, por exemplo, afirmam que a indústria da prostituição é presença cultural poderosa e pervasiva, que envolve a compra de mulheres e crianças por homens. Acreditam que pornografia e prostituição prejudicam a segurança e o status civil de todas as mulheres, ao legitimar a objetificação feminina e propagar a exploração masculina e a violência contra crianças e mulheres. (WHISNAT; STARK, 2004) Para Sheila Jeffreys, que desenvolveu sua teoria a partir do debate do feminismo radical, a legalização da prostituição favoreceria a expansão da indústria e do tráfico de pessoas. (JEFFREYS, 2008)

Esse tipo de concepção fundamenta, no âmbito feminista, posturas contra a prostituição, a pornografia ou o tráfico de pessoas (sem diferenciar este último da migração). A prostituição, para a antropóloga argentina Adriana Piscitelli, atuou como divisor de águas no debate sobre significados e funções do sexo, e as abordagens são influenciadas pela forma como se percebe a sexualidade. (PISCITELLI, 2005) A sexualidade pode ser considerada, conforme a antropóloga estadunidense Gayle 
Rubin, forma de liberação sexual ou de extensão do privilégio masculino, evidenciando a complexidade das relações entre feminismo e sexualidade, produzindo tanto formas retrógradas quanto inovadoras de pensar a sexualidade, sendo importante diferenciar a opressão de gênero da sexual. (RUBIN, 1989)

Ana Gabriela Macedo e Ana Luísa Amaral, ambas professoras de letras em Portugal, consideram que um dos polos que dominam os debates feministas acerca do tema é o feminismo radical, que percebe as prostitutas como vítimas da opressão masculina, que amplia as desigualdades entre homens e mulheres. (MACEDO; AMARAL, 2005) Neste mesmo viés, conforme nos mostra a socióloga espanhola Raquel Osborne, encontramos discussões contra a pornografia, que alegam que as mulheres são tratadas como objeto, gerando relações de violência. (OSBORNE, 2002) A prostituição e a pornografia seriam as piores formas de exploração feminina, e as mulheres adentrariam estas indústrias sempre obrigadas. $\mathrm{O}$ tráfico de pessoas é percebido igualmente como forma de vitimização e opressão, estando sempre ligado ao sexo, como demonstra Kamala Kempadoo, noção permeada pela ideia de que as mulheres só se envolvem sexualmente quando se envolvem afetivamente, não tendo desejo sexual autônomo. (KEMPADOO, 2005)

O Brasil é considerado abolicionista, tendo assinado em I95I a Convenção das Nações Unidas contra o Tráfico de Pessoas e a Exploração da Prostituição Alheia (1949), conhecido como o tratado abolicionista internacional, da Organização das Nações Unidas (ONU). A legislação nacional entende como legal a prostituição, mas ilegais os empreendimentos vinculados a esta e também o rufianismo. (BRASIL, 2002) O abolicionismo fundamenta-se na visão da prostituta como uma vítima, que deve ser libertada e conscientizada da opressão a que está submetida, com a paralela criminalização dos demais envolvidos. Há ações de controle e de supressão e intervenções de caráter profilático e moralizador, como destaca a historiadora Cristiana Schettini Pereira (2005). 


\section{Controlar a prostituição: eixo regulamentarista}

No segundo eixo, o regulamentarista, encontramos visões que se associam à noção de que a prostituição é um mal necessário, devendo ser controlada e higienizada para reduzir os seus males, o que seria associado ao regime legal regulamentarista. Em termos de políticas públicas, esta visão pode gerar práticas de cunho higienista e também cerceador. Nos países regulamentaristas, a prostituição é uma atividade regulamentada, mas que inclui requisitos específicos para tal, que podem abarcar registro em delegacia de polícia e exames médicos obrigatórios, dentre outros. A prostituição é percebida como um mal necessário, gerando consequências negativas para as pessoas que a exercem e para a sociedade, mas também benefícios, como a possibilidade de os homens realizarem sexo por dinheiro, reduzindo a incidência de estupros e violências contra as mulheres. Assim, é considerado importante que seja regulamentada, mas com uma legislação específica, que vise reduzir sua possibilidade de gerar danos como, por exemplo, com a realização de exames periódicos ou a sua redução a áreas específicas das cidades.

Dentre teóricas que se alinham á posição regulamentarista, podemos citar o caso da profissional do sexo francesa Morgane Marteuil (20I4) e do americano Ronald Weitzer (20I2). A primeira, a partir de uma posição marxista, advoga a necessidade de reconhecer a prostituição como trabalho reprodutivo e que, assim como a dona de casa, a prostituta deveria ter seu trabalho reconhecido. Ademais, como trabalho reprodutivo, considera que não haveria grandes diferenças entre a troca de sexo que envolva ou não dinheiro. $\mathrm{O}$ reconhecimento legal seria uma forma de questionar o próprio sistema capitalista (20I4). Podemos observar que a autora se distancia do que é trazido por determinados movimentos de prostitutas que, frequentemente, enfatizam que é um "trabalho como outro qualquer", não devendo ser comparado ao sexo realizado de forma não profissional. 
Weitzer afirma existirem dois paradigmas que se contrapõem, intitulando-os de paradigma do empoderamento (que seria o laboral) e da opressão (abolicionista). Propõe um terceiro, que seria o paradigma polimorfo, compreendendo tanto as questões de empoderamento quanto as de opressão que possam estar presentes na prostituição. $O$ autor realiza análises de locais de prostituição em cidades que adotaram o regime regulamentarista, demonstra que as violações que ocorrem na prostituição são menores em locais fechados e, ademais, estes permitem uma separação das pessoas, evidenciando se alinhar a propostas regulamentaristas, embora com críticas à forma como têm sido executadas em alguns locais. (WEITZER, 2012)

De acordo com a assistente social Marlene Teixeira Rodrigues, o Estado brasileiro reserva o sistema de justiça criminal, em especial o aparato policial, para se incumbir de lidar com a prostituição, visando controlar a atividade, mas sem criar políticas públicas ou outras formas de intervenção, deixando transparecer que o viés predominante é o da atividade como mal necessário. (RODRIGUES, 2004) O país, apesar de ser oficialmente abolicionista, adotou algumas práticas regulamentaristas, incluindo a restrição da atividade em áreas específicas, como ocorreu na Região da Rua dos Guaicurus, em Belo Horizonte, e na Vila Mimosa, no Rio de Janeiro, conforme nos conta a antropóloga Soraya Simões (20I0), ou com regras próprias. (ENGEL, 1989)

\section{Reconhecer a prostituição: eixo laboral}

No terceiro eixo, laboral, encontramos a visão da prostituta como uma trabalhadora, noção profundamente influenciada pela emergência destas como sujeitas políticas, muitas vezes organizadas em torno de um movimento mais ou menos consolidado. Acredita-se que as explorações ocorridas são frutos do estigma e do isolamento, sendo necessário lutar por melhores condições de trabalho (OSBORNE, 2002), já que a violência estaria associada ao caráter informal e subterrâneo da atividade. (KEMPADOO, 2005) 
No dossiê especial Sex Workers Organising, do International Centre for Trade Union Rights ${ }^{4}$ (ICTUR), se debate sobre como uma análise baseada em direitos trabalhistas é relevante para a prostituição, colocando a ênfase das próprias prostitutas sobre seus interesses. (EDITORIAL, 2005)

Julia Bindman, cientista política inglesa, aponta que o trabalho com o sexo não deveria possuir leis específicas, mas ser regulamentado pelas legislações laboral e civil comuns às demais categorias profissionais, o que não ocorre em virtude do status legal e do estigma associado a esse. (BINDMAN, 2004) A não percepção da prostituição como trabalho, segundo a antropóloga argentina Dolores Juliano, é considerada uma forma de desvalorização das prostitutas, numa sociedade em que a condição de trabalhadora é o que determina a valorização das sujeitas (JULIANO, 2004), e a distinção entre trabalho voluntário e forçado implica na negação de direitos humanos das prostitutas, conforme Jo Doezema, que foi coordenadora da Network of Sex Work Projects (NSWP). (DOEZEMA, I998)

Essa visão é perpassada pela noção de que é uma opção mais flexível, melhor remunerada e com jornada de trabalho mais curta do que outras atividades, gerando lucros para profissionais, sua família e demais envolvidas, conforme apontado pela economista do desenvolvimento Lin Leann $\operatorname{Lim}(2004)$, havendo uma ideia de que é uma atividade ocupacional que pode ser livremente escolhida.

A presença de possibilidade de escolha, no âmbito da prostituição, não exclui a existência de formas de opressão, de determinação e controle, mas precisamos identificar quais são estas, como se constituem e se mantém, evitando discursos prontos, que afirmam que a inserção na prostituição, por si só, assegura uma forma de escravidão ou de liberação. Destarte, afirma-se que há, como em qualquer trabalho, uma possibilidade de escolher atuar na prostituição, mesmo que esta liberdade seja influenciada por limites históricos e sociais, como o gênero. (JULIANO, 2004) Visando

\footnotetext{
${ }^{4}$ Rede de Trabalho Sexual.
} 
compreender a forma como essas e outras categorias - como a classe e a geração - interagem, propomos que se pense nas mesmas de modo interseccional, sem hierarquizá-las e buscando refletir sobre diferença e poder, mas também em termos de capacidade de agência das sujeitas, que negociam constantemente seus posicionamentos. (PISCITELLI, 2008) A liberdade depende da quantidade de possibilidades, das facilidades e dificuldades de realização dessas, da importância que tenham uma em relação à outra, nos planos de vida e em relação à identidade e momento, de até que ponto estão abertas ou fechadas, do valor que a sociedade atribui a essas possibilidades. (BERLIN, 1996) Perceber o trabalho sexual como passível de exploração, como qualquer ocupação, pode implicar em bases para a mobilização e lutas por melhores condições de trabalho, direitos e benefícios, bem como para a resistência à opressão, permitindo o surgimento de estratégias para a busca por mudanças. (KEMPADOO, 1998)

\section{Gabriela Leite e a Rede Brasileira de Prostitutas}

Gabriela Leites era filha de uma família de classe média de São Paulo, formada por uma dona de casa e um crupiê, nasceu em I95I e foi registrada como Otília Silva Leite. Em 1969 ingressou no curso de Ciências Sociais da Universidade de São Paulo, mas não o concluiu e logo o trocou pelos atrativos da vida boêmia. Tornou-se prostituta e começou a adotar o nome Gabriela, pelo qual passou a ser reconhecida ao longo de toda sua vida. Transitou pelos mais diversos territórios de prostituição em cidades como São Paulo, Rio de Janeiro e Belo Horizonte. A partir daí essa foi a profissão pela qual gostaria de ser identificada, mesmo tendo abandonado o seu exercício na década de I980, se dizendo "uma puta aposentada".

Gabriela se destacou pela sua forte militância no movimento das prostitutas, tornando-se uma importante liderança deste. Esteve presente desde suas primeiras ações, em I979, na Boca do Lixo, momento em

\footnotetext{
5 Esta introdução é baseada no "In Memorian" escrito por Letícia Barreto à época do falecimento de Gabriela Leite e publicado na Revista Estudos Feministas. (BARRETO, 2013)
} 
que prostitutas e travestis convocaram a sociedade civil a se manifestar em oposição às arbitrariedades cometidas por um delegado contra essa população, o que gerou a organização de uma manifestação na Praça da Sé. O movimento foi se consolidando através de ações como o Primeiro Encontro Nacional de Prostitutas, em I987, no Rio de Janeiro; o surgimento da primeira associação da ocupação, na Vila Mimosa, em I988, seguida por várias outras a partir da década de I990; e a criação do jornal Beijo da Rua, em I988, cujo editor é seu viúvo, Flávio Lenz. Gabriela se mostrou figura essencial em todos esses momentos, começando também a ganhar visibilidade na mídia. Em I988, articulou junto com outras atrizes a primeira parceria com a Coordenação Nacional de DSTs/Aids, do Ministério da Saúde, fundamental para a consolidação do movimento e a obtenção de recursos para campanhas como a "Sem vergonha!", que trazia materiais com frases como "Sem vergonha, garota! Você tem profissão!".

Sua militância se tornou mais institucionalizada com a fundação da Organização Não Governamental (ONG) Davida - prostituição, direitos civis e saúde, que visa à promoção da cidadania das prostitutas, aliada ao rompimento de estereótipos e à promoção de políticas públicas. Uma das ações de mais destaque midiático dessa ONG foi a criação, em 2005, da grife Daspu - cujo nome ironiza a grife Daslu -, que seria uma forma de financiar projetos, mas também de chamar a atenção para o movimento e atuar na promoção da autoestima das prostitutas. À época do lançamento da grife, Gabriela escreveu em sua coluna, no Beijo da Rua, as palavras que abrem este artigo, reivindicando o caráter revolucionário da ação e da possibilidade de empoderamento que abria às mulheres prostitutas.

A luta foi se consolidando em torno da Rede Brasileira de Prostitutas que inclui prostitutas e grupos de prostitutas de diversos estados. Foi adquirindo como bandeiras principais o reconhecimento legal da profissão, a identificação das prostitutas como sujeitas capazes de autodeterminação e o fim da criminalização do entorno da atividade, que abrange os donos de empreendimentos, agenciadores e intermediários. Uma das lutas do movimento de prostitutas é por dissociar estigma e prostituição ao enfa- 
tizar a valorização da identidade profissional, se alinhando ao eixo laboral de reconhecimento da atividade. O movimento no Brasil, caracterizado em grande medida pela Rede Brasileira de Prostitutas (RBP) e tendo Gabriela Leite como uma das figuras de maior destaque, tem gerado alterações em visões das prostitutas como violentadas ou oprimidas, que predominaram durante longo período. A luta principal da RBP é pela percepção da prostituição como uma forma de trabalho e não como meio de escravidão ou submissão, sendo um exemplo do modelo laboral, que, ao invés de discutir sobre as prostitutas, as inclui no debate relativo a qualquer tipo de política voltada ao trabalho do sexo, por vezes questionando o poder do Estado para regular a sua atuação. (WIJERS, 2004)

Algumas das principais conquistas do movimento foram a inclusão da categoria "profissionais do sexo" na Classificação Brasileira de Ocupações, do Ministério do Trabalho e do Emprego, no ano de 2002, e a parceria com deputados federais que propuseram Projetos de Lei (PL), elaborados junto ao movimento de prostitutas, entre os quais podemos destacar o 98/2003, de Fernando Gabeira, já arquivado, e o 4.211/2012, de Jean Wyllys, batizado de Lei Gabriela Leite. O PL 98/2003, de Fernando Gabeira, do Partido dos Trabalhadores (PT-RJ), propõe a exigibilidade de pagamento por serviços de natureza sexual e a descriminalização do entorno da prostituição (casas, agenciadores), argumentando que providências sanitárias e de política urbana poderiam reduzir os efeitos indesejáveis da prostituição. (GABEIRA, 2003) O PL 42II/20II, de Jean Wyllys, do Partido Socialismo e Liberdade (PSOL-RJ), baseou-se no projeto de Gabeira e visa regulamentar a atividade de profissionais do sexo, diferenciada da exploração sexual (essa sim sendo penalizada e vedada), estabelecendo que não pode ser forçada, sem pagamento ou ocorrer lucro dos agenciadores de mais de $50 \%$. O projeto ainda possibilita o trabalho autônomo e em cooperativas. (WYLLYS, 20I2) Ambos os projetos evidenciam que, apesar de o movimento adotar uma postura laboral, por vezes demanda mudanças que dialogam com a regulamentação. No ano de 20I0, Gabriela tentou ela mesma se eleger, se candidatando a deputada 
federal pelo Partido Verde, adotando o slogan "uma puta deputada", no entanto, não alcançou êxito.

Gabriela Leite escreveu dois livros ao longo de sua vida: Eu, mulber da vida, de 1992 (LEITE, 1992), e Filba, mãe, avó e puta, de 2009 (LEITE, 2009), o qual deu origem a uma peça de teatro homônima. Ambas as obras são autobiográficas, trazendo histórias sobre os mais diferentes aspectos da vida da prostituta. $\mathrm{O}$ segundo se destaca por ter sido dividido a partir dos “Io mandamentos da prostituição”, possuindo também um caráter político mais claro.

Era uma pessoa simples e muito afetuosa, gostava de diálogos que aconteciam em clima informal, dizendo que era no botequim que surgiam suas melhores ideias, mas sempre mantinha uma postura combativa e segura dos seus ideais. Não lhe agradavam termos como "profissional do sexo", gostava de ser chamada de puta e lutava para que a palavra não fosse mais associada a algo negativo. Contava com orgulho que sua neta, Tatiany Leite (produtora do filme Filhas de Gabriela, que analisa o legado da avó), dizia querer ser identificada como "neta da puta".

Queria ser reconhecida como feminista, embora sempre destacasse os embates travados com as que ela chamava de feministas ortodoxas, para as quais as prostitutas eram vítimas do machismo a serem resgatadas. Rejeitava todas as ideias abolicionistas e vitimizantes, oferecendo em troca um discurso de liberdade e protagonismo que foi fundamental à colocação das prostitutas enquanto sujeitas políticas de sua própria história. Dizia que, nos últimos anos, havia conseguido travar diálogos com um feminismo mais jovem, embora, em outros momentos, afirmava que a juventude de hoje era, sob alguns aspectos, mais conservadora do que a de sua época. Para ela, a sua luta era uma luta feminista, pela autonomia das mulheres, pelo seu reconhecimento enquanto profissionais capazes de escolher sua ocupação.

Gabriela faleceu às I9 horas do dia Io de outubro de 20I3, no Rio de Janeiro. Era casada com Flávio Lenz, parceiro também de militância, tinha duas filhas, uma neta e um enteado. Vítima de câncer, contra o qual lutou 
por alguns anos, Gabriela não se deixou abater pela doença e seguiu até o fim de sua vida na sua batalha pelos direitos das prostitutas.

\section{Toda puta foi virgem um dia: prostituição e feminismos}

O vídeo-homenagem que preparamos para o evento começa com uma declaração que pensamos representar bem o ativismo feminista de Gabriela. A militante leva a plateia aos risos ao afirmar que recentemente havia se dado conta de que um dia havia sido virgem: "Gente, fui virgem!", diz ela ressaltando depois que se surpreendeu ao pensar que "toda puta foi virgem um dia”. A fala se articulava a um argumento de que ela se considerava prostituta e feminista, embora já tivesse sido questionada por outras feministas se isso seria possível.

As feministas ortodoxas não ouvem a gente. Elas falam tanto em ser livre, mas elas não querem que a gente tenha liberdade. Eu quero ser livre para, inclusive, ser puta. Certo? A liberdade me dá o direito de ser puta também. (LEITE, 2OI2)

A fala de Gabriela sobre a virgindade, por mais jocosa que possa parecer, sobre a liberdade para ser puta, evidencia pontos importantes de conflito entre feminismos e prostituição. Por um lado, ao se dizer virgem, Gabriela se coloca num mesmo patamar que outras mulheres, se igualando a elas. Seu discurso remete à antiga pauta do feminismo que advoga em prol da solidariedade entre mulheres, se reconhecendo como semelhantes (mesmo nas diferenças). Em sua diferença, ela se coloca como sujeita, dotada de agência, e que esta liberdade e autonomia, também tão caras aos feminismos, possam ser acionadas inclusive na sua opção pela prostituição. Se posiciona assim claramente contra as "feministas ortodoxas", que consideram a prostituição uma forma de opressão da qual as mulheres devem ser libertas.

Paralelamente, sua colocação se opõe à tradicional dicotomia entre putas e santas, que opera em formas de divisão entre as mulheres. Segundo 
Kempadoo, existe um modelo que coloca a categoria "mulher" como provedora do trabalho sexual e "homem" como grupo que usufrui dos lucros e do poder. Essa subordinação é essencial à produção de estigmas e à condenação das mulheres que desafiam as fronteiras da "feminilidade". Há uma cisão entre mulheres boas e más, sendo que a imagem da "puta” serve como divisor e disciplinador das mulheres, conformando a maioria à virgindade, domesticidade e monogamia e rechaçando as transgressoras. (KEMPADOO, I998) Juliano aponta que a ideologia dominante divide as mulheres entre boas e más, sendo que as prostitutas são as más e, como tais, completamente desvalorizadas. A autora acredita que essa desvalorização tem duas funções. A primeira seria uma forma de relativizar as vantagens do êxito econômico das prostitutas e a segunda seria uma estratégia pedagógica que serviria ao ideal de garantir que as demais mulheres se conformem à norma. (JULIANO, 2004)

Juliano busca compreender o fenômeno do trabalho sexual e a estigmatização como partes de uma sequência que abrange os papéis familiares e profissionais destinados às mulheres e cuja valorização vai da aceitação ao rechaço. Há um contínuo que, por um lado, encaminha as mulheres “corretas" em direção ao que se espera de boas mães, filhas e esposas e, por outro, desvaloriza as que fogem a essa direção, como as lésbicas, mães solteiras e trabalhadoras do sexo. Assim, pela pressão exercida sobre as pessoas estigmatizadas, busca-se persuadir as demais a agir conforme a norma, evitando que infrinjam os modelos vigentes, o que teria como pena o rechaço social reservado às "mulheres desviantes”. A participação escassa ou marginal das mulheres no mercado de trabalho ou o não reconhecimento de sua atividade como digna se coloca a todas como um obstáculo para que adquiram direitos e deveres. A falta de reconhecimento faz com que se tornem dependentes da "boa vontade" dos indivíduos com os quais se relacionam, perdendo sua autonomia. Para a autora, apenas por meio do fim da estigmatização se poderá garantir uma verdadeira opção de escolha profissional. (JULIANO, 2005) 
A problematização sobre a possibilidade de liberdade e de autonomia dentro da experiência da prostituição é trazida também por Gabriela quando afirma gostar da profissão. Por mais que ressalte em diversos momentos de sua trajetória que a prostituição pode ser perpassada por experiências de opressão e violência, especialmente favorecidas pelo contexto de ilegalidade que a cerca, a ativista aposta na agência. Abaixo, algumas falas de Gabriela Leite sobre o tema (BARRETO; MAYORGA, 20I5)

Eu não acredito que existam pessoas sem opção. As pessoas tomam uma atitude. Por menor que a atitude seja, por menos opções que você tenha, você toma. Ninguém é levado como se um vento te levasse.

Isso eu acho que é o que mais atrapalha hoje. Qualquer questão da prostituição, da mulher prostituta no seu movimento é ela ser considerada vítima e ser considerada vítima de uma sociedade injusta e pá pápá e por ser considerada vítima a colocar numa situação maior de estigma.

\section{Por uma busca identitária: prostituição e trabalho}

A escritora destaca em seu primeiro livro a necessidade de descriminalização do entorno da prostituição para que as prostitutas possam ter acesso a direitos trabalhistas, acessados por trabalhadores em diversos contextos. Com esta afirmação, Gabriela demonstra que não considera a prostituição como atividade laboral livre de dificuldades, mas que essas não estariam, como visto por determinadas feministas, vinculadas à prática do sexo comercial em si, mas sim à forma como a atividade é percebida e regulamentada.

No caso específico da prostituição, atividade de economia informal que envolve centenas de milhares de pessoas em todo o país, a regularização beneficiaria, logo de cara, a prostituta, que poderia ter seus direitos trabalhistas assegurados. A partir daí, beneficiaria toda 
a clientela da zona - milhões de brasileiros de todas as classes. As prostitutas poderiam brigar pelo saneamento básico no local de trabalho, com base nas leis sobre insalubridade, poderiam ter direito a férias remuneradas, repouso semanal, décimo terceiro salário, fundo de garantia, aposentadoria, melhores condições de educação e saúde. $\mathrm{O}$ que acaba com uma prostituta, o que tira sua dignidade e sua saúde, não é transar, não é fazer sexo profissional. O que acaba com ela é a falta de condições de trabalho: não tem água para se lavar, o quarto não tem condições de higiene, tem percevejo andando pelas paredes se ela não trabalha um dia ou mais, vem a cafetina dizer que ela tem que trabalhar para pagar pelo dia de trabalho e pelas faltas, e a prostituta fica devendo um monte de dinheiro. Vira escrava da afetina. Não há regra para nada, nenhuma legislação que a ampare. (LEITE, I992, p. I7I)

Para Gabriela, a luta pelos direitos das prostitutas passaria, em grande medida, pela descriminalização, que auxiliaria também na construção de uma visão menos estigmatizada da atividade e das pessoas que a exercem.

O que eu quero e o que eu sempre quis é que para essas pessoas que vão para a prostituição é que elas tenham um melhor ambiente de trabalho, que elas sofram menos preconceitos, que elas tenham direitos como todo mundo. Que elas não vivam como acontece em algumas cidades mais longínquas do país de viver em semi-escravidão muitas vezes e você nem saber o que está acontecendo lá. A questão das meninas mais jovens que nós não temos controle sobre isso. Que como é uma atividade que não está legalizada, esses caras donos de bordel e essas coisas todas, de hotéis e casas e de todo o ambiente da prostituição eles pagam para poder funcionar. Entendeu? Eles são ilegais, eles pagam a corrupção policial para funcionar. (LEITE, 2009)

O reconhecimento da prostituição enquanto um trabalho vem sendo defendido por prostitutas de diversas partes do mundo a partir da opção por termos como "profissionais do sexo" ou "trabalhadoras do sexo". Apesar disso, Gabriela sempre manteve sua aposta no uso da palavra "puta”, visando eliminar o estigma atrelado a ela e fortalecendo a identidade das 
pessoas que exercem a atividade, como podemos observar nos trechos de entrevistas cedidas por ela à pesquisadora Laura Murray e que fazem parte do vídeo-homenagem. (BARRETO; MAYORGA, 2015)

Eu gosto dessa palavra desde sempre. Acho uma palavra sonora, quente e que eu acho que toda puta, se não vivesse com tanto estigma nas suas cabeças elas usariam. E eu acho que a gente começaria até a vencer o preconceito antes, porque as pessoas iam levar um choque e depois eles iam dizer 'ah, é verdade, ela é uma puta'.

A gente tem que mudar. Filha da puta deve ser um motivo de orgulho para as filhas da gente. Se a gente não toma as palavras pelo chifre e assume elas, a gente não muda nada. Então precisa ter identidade, aí a gente muda alguma coisa.

Apesar da opção pelas integrantes do movimento organizado por termos como "profissionais do sexo", "prostituta" ou "puta”, com sua adesão a uma visão da atividade como sendo laboral e merecedora de direitos trabalhistas, esta questão não é fechada, unânime. Entre as prostitutas que encontramos pela cidade, algumas dizem querer ser chamada dessas formas, outras como "trabalhadoras do sexo" ou "garota de programa", ou ainda nem se considerar prostitutas, já que exercem o trabalho ocasionalmente.

Gabriela Leite, na "Coluna da Gabi” no ano de 2002, destaca que, apesar de, naquele momento, terem optado pelo nome politicamente correto "profissional do sexo", ela considera que é uma expressão que não representa a categoria. Destaca seu apreço pela palavra "puta", que considera "linda, sonora e importante", embora seja um palavrão usado, inclusive, para estigmatizar suas filhas e netas. Para ela, é importante reivindicar a palavra e tirar seu peso, para que se torne um elogio, algo do qual suas descendentes possam ter orgulho. (LEITE, 2002b) Essa posição foi sustentada pela prostituta até o fim de sua vida, nos mais diferentes espaços e contextos. Em outra coluna, no mesmo ano, Leite ainda afirma que ser prostituta é tão bom ou ruim quanto qualquer outra atividade, mas que 
é necessário que as trabalhadoras se reconheçam como especialistas em fantasias sexuais e que é isso que comercializam. (LEITE, 2002a)

\section{O legado de Gabriela e do movimento de prostitutas}

O movimento de prostitutas tem se mostrado como importante ator no cenário político atual, se mostrando progressivamente capaz de pautar os debates que permeiam a prostituição. Nesse processo, Gabriela se mostrou uma figura chave para publicizar as questões caras às prostitutas $\mathrm{e}$ conclamar que a prostituição fosse compreendida pelo viés dos direitos humanos, laborais e sexuais e não da doença, do transtorno, da anomalia.

Ao longo dos seus mais de 30 anos de ativismo no Movimento de Prostitutas, Gabriela se tornou uma importante referência no debate sobre prostituição no Brasil e no mundo. Junto a outras militantes, construiu um movimento que nos evidencia, constantemente, a necessidade de repensar não só a prostituição e a forma como a vemos, mas também a sexualidade e as relações de gênero. As posturas da militante e do movimento nos levam a construir novas formas de luta feminista em que é fundamental dialogar com as prostitutas, ao invés de produzir discursos sobre elas. É necessário construir uma troca efetiva em que nós feministas estejamos abertas a rever nossas crenças e desconfiar de nossas posições. Somente assim será possível a ampliação das sujeitas dos feminismos com a inclusão efetiva das prostitutas e de suas reivindicações.

\section{Referências}

BARRETO, L. C. In Memoriam: Gabriela Leite. Revista Estudos Feministas, Florianópolis, v. 21, n. 4, p. 945-946, 2013. 
BARRETO, L. C. Somos sujeitas políticas de nossa própria bistória: Prostituição e feminismos em Belo Horizonte. 20I5. 26I f. Tese (Doutorado Interdisciplinar em Ciências Humanas) - Centro de Filosofia e Ciências Humanas Universidade Federal de Santa Catarina, 2015.

BARRETO, L. C.; MAYORGA, C. \#Somos todas Gabriela. In: SEMINÁRIO ENLAÇANDO SEXUALIDADES. 4. Salvador, 2015. Disponível em: <https://www.youtube.com/watch?v=34ZZzAordk4>. Acesso em: 2 jul. 2016.

BERLIN, I. Cuatro ensayos sobre la liberdad. Madrid: Alianza Editorial, 1996.

BINDMAN, J. Trabajadoras/es del sexo, condiciones laborales y derechos humanos: problemas “típicos" y protección 'atípica. In: OSBORNE, R. (Org.). Trabajadoras del sexo: derechos, migraciones y tráfico en el siglo XXI. Barcelona: bellaterra, 2004. p. 99-III.

BRASIL. Ministério da Saúde. Secretaria de Políticas de Saúde. Coordenação Nacional de DST e Aids. Profissionais do sexo: documento referencial para ações de prevenção das DST e da aids / Secretaria de Políticas de Saúde, Coordenação Nacional de DST e Aids. Brasília, DF, 2002.

DOEZEMA, J. Forced to choose: beyond the voluntary v. forced prostitution dichotomy. In: KEMPADOO, K.; DOEZEMA, J. (Org.). Global sex workers: rights, resistance and redefinition. New York and London: Routledge, 1998. p. 34-50.

EDITORIAL: the unionisation of sex workers. International Union Rights, London, v. 2, n. 4, p. 2, 2005.

ENGEL, M. Meretrizes e doutores: saber médico e prostituição no Rio de Janeiro (1840-I890). São Paulo: Editora Brasiliense, 1989.

GABEIRA, F. Projeto de Lei 98/2003. Dispõe sobre a exigibilidade de pagamento por serviço de natureza sexual e suprime os arts. 228, 229 e 23I do Código Penal. Brasília, DF: Câmara dos Deputados, 2003.

JEFFREYS, S. The idea of prostitution. 2. ed. North Melbourne: Spinifex Press, 2008.

JESUS, J. G. de. Guia técnico sobre pessoas transexuais, travestis e demais transgêneros, para formadores de opinião. Brasília: EDA/FBN, 20I2. Disponível em: <http:// www.sertao.ufg.br/up/r6/o/ORIENTA\% $\mathrm{C}_{3} \% 87 \% \mathrm{C}_{3} \% 95$ ES_SOBRE_ 


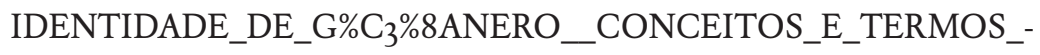
_2\% 2 \% $\%$ AA_Edi\% $\mathrm{C}_{3} \% \mathrm{~A}_{7} \% \mathrm{C}_{3} \% \mathrm{~A}_{3}$ o.pdf>. Acesso em: 2 jul. 2016.

JULIANO, D. El peso de la discriminación: debates teóricos y fundamentaciones. In: OSBORNE, RAQUEL (Org.). Trabajadoras del sexo: derechos, migraciones y tráfico en el siglo XXI. Barcelona: Bellaterra, 2004. p. 43-55. JULIANO, D. El trabajo sexual en la mira: Polémicas y stereotipos. Cadernos Pagu, Campinas, n. 25, p. 79-106, 2005.

KEMPADOO, K. Introduction: globalizing sex workers rights. In: KEMPADOO, K.; DOEZEMA, J. (Org.). Global sex workers: rights, resistance and redefinition. New York and London: Routledge, 1998. p. I-28.

KEMPADOO, K. Mudando o debate sobre o tráfico de mulheres. Cadernos Pagu, Campinas, n. 25, p. 55-78, 2005.

LEITE, G. Caminho aberto para a puta cidadã. Beijo da Rua, Rio de Janeiro, 2005 .

LEITE, G. Eu, mulher da vida. Rio de Janeiro: Rosa dos Tempos, 1992.

LEITE, G. Filha, mãe, avó e puta: a história de uma mulher que decidiu se prostituir. Rio de Janeiro: Objetiva, 2009.

LEITE, G. Quem entende a gente? Beijo da Rua, Rio de Janeiro, abr. 2002a.

LEITE, G. Reforma da lei penal: prostituição. Rio de Janeiro: OAB-RJ, 2012

LEITE, G. Sem vergonha de ser puta. Beijo da Rua, Rio de Janeiro, mar. 2002b.

LIM, Lin Leann. El sector del sexo: la contribución económica de una industria. In: OSBORNE, RAQUEL (Org.). Trabajadoras del sexo: derechos, migraciones y tráfico en el siglo XXI. Barcelona: Edicions Bellaterra, 2004. p. $57-83$.

MACEDO, A. G.; AMARAL, A. L. Dicionário da crítica feminista. Porto: Edicões Afrontamento, 2005.

MARTEUIL, M. Le travail du sexe contre le travail. Revue Periode, Ottawa, 2014 .

MERTEUIL, M. Le travail du sexe contre le travail. Revue Periode, Ottawa, 20I4. Disponível em: <http://revueperiode.net/le-travail-du-sexe-contre-letravail/>. Acesso em: 2 jul. 2016. 
MAYORGA, C. Articulaciones de la exclusión: la política de atención a prostitutas inmigrantes en Madrid. Revista de Estudios Transfronterizos - Si Somos Americanos (INTE/ Chile), v. XIV, p. 48-74, 2012.

MAYORGA, C. Cruzando fronteiras: Prostituição e imigração. Cadernos Pagu Campinas, v. 37, p. 28-60, 2011.

OSBORNE, R. La construcción sexual de la realidad: un debate en la sociología contemporánea de la mujer. 2. ed. Madrid: Ediciones Cátedra, 2002.

PEREIR, C. Si. Lavar, passar e receber visitas: debates sobre a regulamentação da prostituição e experiências de trabalho sexual em Buenos Aires e no Rio de Janeiro, fim do século XIX. Cadernos Pagu, Campinas, v. 25, p. 25-54, 2005.

PISCITELLI, A. Apresentação: gênero do mercado do sexo. Cadernos Pagu, Campinas, v. 25, p. 2-10, 2005.

PISCITELLI, A. Interseccionalidades, categorias de articulação e experiências de migrantes brasileiras. Sociedade e Cultura, Goiânia v. II, n. 2, p. 263-274, 2008.

RODRIGUES, M. T. O sistema de justiça criminal e a prostituição no Brasil contemporâneo. Sociedade e Estado, Brasília, DF, v. I9, n. I, p. 15I-I72, 2004.

RUBIN, G. Thinking sex: notes for a radical theory of the politics of sexuality. In: VANCE, CAROLE (Org.). Pleasure and danger: exploring female sexuality. London: Pandora, 1989. p. 267-319.

SIMÕES, S. S. Vila Mimosa: etnografia da cidade cenográfica da prostituição carioca. Niterói, Rio de Janeiro, Brasil: EdUFF, 2010.

WEITZER, R. Legalizing prostitution: From illicit vice to lawefull business. New York and London: New York University Press, 2012.

WHISNAT, R; STARK, C. Introduction. In: WHISNAT, R.; STARK, C. (Org.). Not for sale: Feminists resisting prostitution and pornography. Melbourne: Spinifex Press, 2004. .

WIJERS, M. Delincuente, victima, mal social o mujer trabajadora: perspectivas legales sobre la prostitución. In: OSBORNE, R. (Org.). Trabajadoras del sexo: derechos, migraciones y tráfico en el siglo XXI. Barcelona: Edicions Bellaterra, 2004. p. 209-221.

WYLLYS, J. Projeto de Lei n. 42II/2OI2. Regulamenta a atividade dos profissionais do sexo. Brasília, DF: Câmara dos Deputados, 20 I2. 


\section{Sobre as orgnizadoras}

\section{Suely Messeder}

Atualmente é professora titular da Universidade Estadual da Bahia (UNEB) e do Programa de Pós-Graduação em Crítica Cultural. Coordenadora do Doutorado Multi-Institucional e Multidisciplinar em Difusão do Conhecimento (DMMDC) da Universidade Federal da Bahia (UFBA), Universidade Estadual da Bahia (UNEB), Universidade Estadual de Feira de Santana (UEFS), Instituto Federal da Bahia (IFBA), Laboratório Nacional de Computação Científica (LNCC) e do Campus Integrado de Manufatura e Tecnologia (SenaiCimatec). Doutora em antropologia pela Universidade de Santiago de Compostela, na Espanha. É a idealizadora do Seminário Enlaçando Sexualidades. Foi a primeira secretária da Associação Brasileira de Estudos de Homocultura $(\mathrm{ABEH})$ no decorrer da gestão de 2010 até 20I2. É gestora do Termo de Cooperação Técnica 
entre o Ministério Público e a UNEB para a articulação e interação em atividades da área técnica-científica, tendo por objetivo a proteção e a defesa dos direitos humanos da população de Lésbicas, Gays, Bissexuais, Travestis, Transexuais e Transgêneros (LGBT). É associada ao grupo de trabalho de Homocultura e Linguagens da Associação Nacional de PósGraduação e Pesquisa em Letras e Linguística (ANPOLL). Atualmente é membro da Câmara Básica de Assessoramento e Avaliação Técnica da Fundação de Amparo à Pesquisa do Estado da Bahia (FAPESB). Tem publicações sobre sexualidades, relações gênero, masculinidades, masculinidades em corpos femininos, feminismos, relações raciais e migrações internacionais, cultura, interdisciplinaridade e interseccionalidade.

\section{Mary Garcia Castro}

Nasceu no Rio, mas se considera parte do povo hifenizado: carioca-baiana-cidadã do mundo. Formada em Sociologia-Estudos Culturais pela Universidade Federal da Bahia (UFBA) do Chile-da Florida (Gainesville) e também pela City University of New York e Universidade de Campinas (Unicamp), essas por estudos pós. Foi pesquisadora do Conselho Nacional de Desenvolvimento Científico e Tecnológico (CNPq) com bolsa produtividade (20I0-20I3). Tem publicações sobre gênero, feminismos, juventudes e migrações internacionais, adentrando-se mais recentemente em debates sobre sexualidades e interseccionalidades. Aposentada da UFBA, leciona em dois programas de Pós-Graduação na Universidade Católica de Salvador (UCSAL): Pós-graduação em Políticas Sociais e Cidadania e Pós-Graduação em Família na Sociedade Contemporânea. E ainda é avó de quatro netos, dois afro-baianos e dois caucasianos-cariocas. Não disse que transito e combino e desestabilizo identidades, ou busco? Então só podia me encontrar bem no e com o povo, as polvas do Enlaçando. 


\section{Laura Moutinho}

Atualmente é professora do Departamento de Antropologia e do Programa de Pós-Graduação em Antropologia (PPGAS) ambos da Universidade de São Paulo (USP) e doutora em Antropologia Cultural pela Universidade Federal do Rio de Janeiro (UFRJ). Realizou pós-doutorado na Universidade de Princeton, com apoio da Coordenação de Aperfeiçoamento de Pessoal de Nível Superior (Capes) e é bolsista produtividade nível 2 do Conselho Nacional de Desenvolvimento Científico e Tecnológico (CNPq). Foi pesquisadora visitante no African Gender Institute, da University of Cape Town (UCT) na África do Sul e foi também Visiting Professor of Public and International Affairs na Universidade de Princeton (Estados Unidos). Foi pesquisadora e ativista do então nascente Centro Latino-Americano em Sexualidade e Direitos Humanos (CLAM) e Professora visitante no Instituto de Medicina Social (IMS) da Universidade Estadual do Rio de Janeiro (UERJ), tendo recebido Moção Honrosa da Câmara Municipal do Rio de Janeiro pelo trabalho sobre gênero e raça realizado em favela da zona oeste. Foi membro da Comissão Científica que organizou o VI Congresso Internacional de Estudos de Diversidade Sexual e de Gênero (20I2) da Associação Brasileira de Estudos de Homocultura $(\mathrm{ABEH})$, tendo atuado no Comitê Científico e na organização de diversas edições do Seminário Enlaçando Sexualidades. Atualmente é membro do comitê editorial da Revista de Antropologia da USP, na qual já atuou como editora-chefe. Publicou o livro Razão, Cor e Desejo: uma análise dos relacionamentos afetivo-sexuais inter-raciais no Brasil e Africa do Sul, Editora Unesp: São Paulo, 2004, graças ao Prêmio EDUSC \ANPOCS para melhor tese de doutorado|edição 2003. 


\section{Apresentação dos autores}

\section{Anderson Ferrari}

Possui licenciatura (I99I) e bacharelado (1994) em História pela Universidade do Estado do Rio de Janeiro (UERJ), mestrado em Educação (2000) pela Universidade Federal de Juiz de Fora (UFJF) e doutorado em Educação (2005) pela Universidade Estadual de Campinas (Unicamp). Atualmente é professor adjunto de Ensino de História da Faculdade de Educação da UFJF, lecionando as disciplinas de Prática Escolar, Fundamentos TeóricoMetodológicos em História e Didática e Prática do Ensino de História. É professor permanente do Programa de Pós Graduação em Educação (PPGE) da UFJF. Tem experiência na área de educação, com ênfase em linguagem conhecimento e formação de professores, atuando principalmente nos seguintes temas: educação, gênero, sexualidade, currículo e homossexualidade. Em 2010 desenvolveu o período de pós-doutorado na Faculdade de Belas Artes da Universidade de Barcelona, trabalhando 
com a relação entre cultura visual, educação e homossexualidades. Em 2013 foi agraciado com a menção honrosa Cora Coralina do edital da Associação Nacional de Pós-Graduação e Pesquisa em Educação (Anped)/ Secretaria de Educação Continuada, Alfabetização, Diversidade e Inclusão (Secadi) pela importante contribuição para área de diversidade sexual e educação. entre 2014 a 2016 ocupou o cargo de presidente nacional da Associação Brasileira de Estudos da Homocultura (ABEH).

\section{Beatriz Pagliarini Bagagli}

Também conhecida como Bia, é estudante de Letras da Universidade Estadual de Campinas (Unicamp). Ingressou em Letras no ano de $201 \mathrm{I}$ e pretende concluir o curso no final de 2015. Escreve para o blog Transfeminismo desde 2013 e nesse percurso tem tentado articular teoricamente os campos de estudos do discurso com os de gênero. Participa do grupo de estudos Mulheres em Discurso.

\section{Cássia Cristina Furlan}

Licenciada em Educação Física pela Universidade Estadual de Maringá (UEM). Especialista em Educação Profissional integrada à Educação Básica no Programa Nacional de Integração da Educação Profissional com a Educação Básica na Modalidade de Educação de Jovens e Adultos (Proeja). Possui mestrado em Educação pela UEM. Atualmente é doutoranda em Educação pela UEM, direcionando-se para a área de pesquisa sobre as questões de gênero, sexualidade e diversidade na infância e formação docente, participante do Grupo de pesquisa Núcleo de Pesquisas e Estudos em Diversidade Sexual

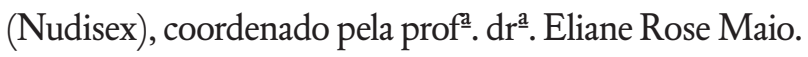

\section{Claudia Andréa Mayorga}

Doutora em Psicologia Social (2007) pela Universidade Complutense de Madri, Espanha, com foco em estudo sobre gênero, política e feminismo. É professora do Departamento de Psicologia da Universidade Federal de 
Minas Gerais (UFMG) e do Programa de Pós-Graduação em Psicologia. Coordena o Núcleo de Ensino, Pesquisa e Extensão Conexões de Saberes na UFMG; é tutora Programa de Educação Tutorial (PET) Conexões. Atuou como pesquisadora visitante na Universidade Complutense de Madrid (2OII e 20I2). Atualmente é editora da Revista Interfaces, revista de extensão da UFMG, e coeditora da Revista Psicoperspectivas (Chile). Foi editora chefe da Revista Psicologia \& Sociedade, periódico científico da Associação Brasileira de Psicologia Social (Abrapso) (2012-2015). Foi membro do Comitê Editorial de Scielo em Perspectiva - Humanas (20I4 e 20I5). Foi membro da Diretoria Nacional da Abrapso (2004/2005) e vice -presidente da Abrapso Regional Minas (2006/2007). Participa do grupo de trabalho da Associação Nacional de Pesquisa e Pós-Graduação em Psicologia (Anpepp), Psicologia, Política e Sexualidades. Como editora da Revista Psicologia \& Sociedade, recebeu grant da American Psychological Association (20I2/20I3). Atualmente é pesquisadora contemplada pelo Programa Pesquisador Mineiro (PPM) do Fundação de Amparo à Pesquisa do Estado de Minas Gerais (Fapemig) (2015-2017). Áreas de pesquisa e extensão: psicologia social e feminismos com os seguintes temas: gênero, relações raciais, sexualidade e política; interseccionalidade e migrações internacionais; psicologia comunitária, favela e intervenção psicossocial; políticas públicas e participação social; juventude e participação.

\section{Dante Augusto Galeffi}

Possui graduação em Arquitetura (1979) pela Universidade Federal da Bahia (UFBA), especialização em Restauração de Monumentos (1980I982) na Universidade de Roma, mestrado em Arquitetura e Urbanismo pela UFBA (1994) e doutorado em Educação pela UFBA (I999). Atualmente é professor titular da UFBA, lotado no Departamento de Educação II da Faculdade de Educação. Tem experiência na área de filosofia, com ênfase em filosofia da educação, atuando principalmente nos seguintes temas: ensino de filosofia, filosofia da educação, epistemologia 
do educar, fenomenologia, hermenêutica, linguagem, educação transdisciplinar, estética e ética. É professor permanente do Programa de Pesquisa e Pós-Graduação em Educação (mestrado e doutorado) e do Doutorado Multi-Institucional e Multidisciplinar em Difusão do Conhecimento (DMMDC), ambos da UFBA. É líder do Grupo de Pesquisa Epistemologia do Educar e Práxis Pedagógica. Desenvolve atualmente pesquisas de epistemologia da complexidade, transdisciplinaridade, epistemologia do educar transdisciplinar, ética e estética.

\section{Eliane Rose Maio}

Possui graduação em Psicologia (1984) pela Universidade Estadual de Maringá (UEM), mestrado em Psicologia pela Universidade Estadual Paulista (UNESP)/Assis (2002), doutorado em Educação Escolar pela UNESP/Araraquara (2008), Pós-Doutorado em Educação Escolar na UNESP de Araraquara, com a temática da Trajetória da Educação Sexual no Brasil.É professora da UEM, no Departamento de Teoria e Prática da Educação. Tem experiência na área de educação, atuando principalmente nos seguintes temas: psicopedagogia, aprendizagem, sexualidade, gênero, diversidade sexual e educação em sexualidade. Realizou um estágio de três meses na Universidade de Alcalá, em Guadalajara, Espanha, como bolsista da Fundación Carolina, com um projeto sobre Formação Docente e Gênero. Professora do mestrado e doutorado em educação da UEM. Atua como membro da Associação Nacional de Pós-Graduação e Pesquisa em Educação (Anped), do GT-23 - Gênero, Sexualidade e Educação. É lider do grupo de pesquisa CNPq, intitulado Núcleo de Pesquisa e Estudo em Diversidade Sexual (Nudisex). Autora dos livros: O nome da coisa, fruto de sua tese de doutorado, Violencia sexual contra criança: contributos para a formação docente. Gênero, direitos e diversidade sexual: trajetórias escolares (Org.), Observatório de violência de gênero: entre políticas públicas e práticas pedagógicas (Org.) e Educação, saúde, gênero e sexualidade: diálogos possiveis (Org.) 


\section{Emerson da Cruz Inácio}

Possui graduação (1996) e mestrado (2000) em Letras pela Universidade Federal Fluminense (UFF) e doutorado em Letras (Letras Vernáculas/Literatura Portuguesa) pela Universidade Federal do Rio de Janeiro (UFRJ) (2006), tendo sido orientado pelo prof. dr. Jorge Fernandes da Silveira. Desde 2006 é professor doutor da Faculdade de Filosofia, Letras e Ciências Humanas da Universidade de São Paulo (USP) e antes disso ministrava aulas de Literatura e Língua Portuguesa no Colégio Pedro II do Rio de Janeiro. Tem experiência na área de letras, com ênfase em literatura comparada, atuando principalmente nos seguintes temas: poesia do século XX, literatura afrodescendente, estudos culturais, Teoria Queer e estudos gays e lésbicas, focalizando a tensão e a convergência desses com a crítica literária, o corpo, a subjetividade, a cultura e a formação dos cânones literários.

\section{Enézio de Deus Silva Júnior}

Mestre e doutor em Família na Sociedade Contemporânea pela Universidade Católica do Salvador (UCSal), bacharel em Direito pela Universidade Estadual de Santa Cruz (UESC) e Especialista em Direito Público pela Universidade Salvador (Unifacs). Atuação na pesquisa/docência, com ênfase em direitos das famílias, direitos humanos e análise do discurso. Autor dos livros: A possibilidade jurídica de adoção por casais bomossexuais ( $5^{\text {a }}$ edição, Editora Juruá), Assassinatos de bomossexuais e travestis: retratos da violência bomo(trans)fóbica (Instituto Memória), Luzeiros de amor (Editora Juruá) e Retirolândia: memória e vida (Editora Juruá). Coordenador e coautor do livro União estável entre homossexuais: comentários à decisão do STF face à $A D I$ 4.277/2009 e à $A D P F$ I32/2008 (Editora Juruá). Coautor dos livros: Diversidade sexual e direito bomoafetivo (Editora Revista dos Tribunais); Minorias sexuais: direitos e preconceitos (Editora Consulex) e $O$ regresso (Editora Juruá). Servidor público concursado da carreira de Especialista em Políticas Públicas e Gestão Governamental (EPPGG), vinculado ao 
quadro permanente da Secretaria da Administração do Estado da Bahia (SAEB) e advogado (OAB/BA 20.9I4).

\section{Fernanda Andrade Leal}

Doutoranda e mestre em Família na Sociedade Contemporânea pela Universidade Católica de Salvador (UCSal). Especialista em psicologia perinatal pelo Instituto Brasileiro de Psicologia Perinatal (Gerar - SP). Graduada em Psicologia pela Faculdade Ruy Barbosa. Atua como psicanalista. Fundadora e psicóloga do Instituto de Atenção à Família e Acolhimento Materno Infantil (Matern).

\section{Flávia Ferreira Pires}

É professora na Pós-Graduação em Sociologia e Pós-Graduação em Antropologia da Universidade Federal da Paraíba (UFPB), onde trabalha desde 2008. Realizou Pós-Doutorado em Sheffield University com a professora Allison James (20I2-20I4) e no Museu Nacional da Universidade Federal do Rio de Janeiro (UFRJ) (2008) com o prof. Moacir Palmeira. Finalizou seu doutorado em Antropologia Social no Museu Nacional da UFRJ (2007), mestrado em Antropologia Social no Museu Nacional da UFRJ (2003), sendo orientada pelo prof. Otávio Velho. Possui graduação em Ciências Sociais pela Universidade Federal de Minas Gerais (UFMG) (2000), orientada pela professora Léa Perez. Trabalhou, principalmente, com os seguintes temas: antropologia da religião, antropologia da criança e da infância, antropologia da festa, teoria antropológica e métodos de pesquisa. Ultimamente vem pesquisando políticas públicas e o Programa Bolsa Família. Área etnográfica: semi-árido da Paraíba/ Brasil. Membro associado ao Centre for the Study of Childhood and Youth (CSCY) em Sheffied University, Inglaterra; pesquisadora do Centro de Estudos da Religião Pierre Sanchis (CER), da UFMG, e líder do grupo de pesquisa Criança: Cultura e Sociedade (CRIAS) da (UFPB). É a favor da manutenção e valorização do Ministério de Ciência, Tecnologia e Inovação e do retorno à normalidade democrática. 


\section{Fernando Pocahy}

Professor adjunto da Universidade do Estado do Rio de Janeiro (UERJ), atuando na Faculdade de Educação/ Programa de Pós-Graduação em Educação (PROPEd); realizou pós-doutorado junto ao Programa de PósGraduação em Antropologia Social da Universidade Federal de Santa Catarina (UFSC), com bolsa concedida pela Coordenação de Aperfeiçoamento de Pessoal de Nível Superior (Capes)/Reestruturação e Expansão das Universidades Federais (Reuni), vinculado ao Núcleo de Identidade de Gênero e Subjetividade (NIGS); doutorado em Educação e mestrado em Psicologia Social e Institucional, ambos pela Universidade Federal do Rio Grande do Sul (UFRGS) com bolsa Capes, vinculado respectivamente ao Grupo de Estudos em Educação e Relações de Gênero (GEERGE) e ao Laboratório de Psicologia e Políticas Públicas. Fez estágio doutoral na Université Lumière Lyon 2 (Centre Louise Labé), França (bolsa Capes), e período como doutorando visitante na École Doctorale Romande en Études Genre, Université de Lausanne, Suíça. Possui Especialização em Projetos Sociais e Culturais pela UFRGS, com bolsa da Fundação Maurício Sirotsky. É graduado em Psicologia pela Universidade do Vale do Rio dos Sinos (Unisinos), onde foi bolsista de extensão da Pró-Reitoria Comunitária e de Extensão (Procex). É coordenador do Grupo de Estudos sobre Gênero, Sexualidade e Interseccionalidades na Educação e na Saúde (Geni) e pesquisador do Laboratório Integrado em Diversidade Sexual e de Gênero, Políticas e Direitos (Lidis) na UERJ e bolsista da Fundação de Amparo à Pesquisa do Estado do Rio de Janeiro (Faperj) nos programas Jovem Cientista do Nosso Estado e Prociência. Membro do GT 23 - Gênero, Sexualidade e Educação da Associação Nacional de Pós-Graduação e Pesquisa em Educação (Anped) e do GT Psicologia, Sexualidade e Política da Associação Nacional de Pesquisa e Pós-Graduação em Psicologia (Anpepp). Tem realizado estudos e intervenções a partir de interlocuções entre educação e saúde, interessado principalmente nos seguintes temas: corpo, geração, gênero, sexualidade e interseccionalidades 
nos processos de subjetivação, utilizando-se de abordagens pós-estruturalistas em articulação com os Estudos Feministas, Estudos Queer e os Estudos Culturais Foucaultianos.

\section{José Euclimar Xavier de Menezes}

Graduado em Teologia e Filosofia. Mestre e doutor em Filosofia Contemporânea pela Universidade Estadual de Campinas (Unicamp). Pós-doutor em Filosofia Contemporânea pela Pontifícia Università Lateranensi, Roma. Atuou como docente e pesquisador nas seguintes instituições: Pontifícia Universidade Católica (PUC) de São Paulo, Faculdade Ruy Barbosa, Faculdade Santíssimo Sacramento e no Programa de Stricto Sensu em Família na Sociedade Contemporânea da Universidade Católica de Salvador (UCSal). Foi Pró-Reitor de Pesquisa e Pós-Graduação da mesma instituição. Atualmente atua na Faculdade Social da Bahia como docente e pesquisador e no Programa de Stricto Sensu em Direito, Governança e Políticas Públicas da Universidade Salvador (Unifacs). Tem experiência nas áreas da filosofia, da psicologia e do direito, atuando principalmente nos seguintes temas: direitos humanos, políticas públicas, subjetividade, sociabilidade, sujeição, epistemologia, saúde mental. É editor da Revista Webqualis da Coordenação de Aperfeiçoamento de Pessoal de Nível Superior (Capes), Diálogos Possíveis.

\section{Letícia Cardoso Barreto}

Doutora em Ciências Humanas pela Universidade Federal de Santa Catarina (UFSC), com área de concentração estudos de gênero; mestre em Psicologia pela Universidade Federal de Minas Gerais (UFMG), com área de concentração em psicologia social e psicóloga formada pela UFMG. Atua principalmente nas áreas de psicologia social, estudos de gênero e sexualidade, com enfoque na temática da prostituição e feminismo. 


\section{Mara Viveros Vigoya}

Possui Doutorado em Ciencias Sociales de la École des Hautes Études en Sciences Sociales, e o mestrado em Estudios de las Sociedades Latinoamericanas del Instituto de Altos Estudios de America Latina. É professora do Departamento de Antropologia da Universidad Nacional de Colombia e da Escuela de Estudios de Género. Seus interesses de pesquisa são temas vinculados com a relação entre as diferenças e desigualdades sociais, as intersecciones de gênero,sexualidade, classe, raça e etnicidade na dinâmica social das sociedades latino-americanas. É autora de múltiplos textos com destaque: Dominación masculina y perspectivas de cambio: desnaturalizar la jerarquia; De quebradores y cumplidores: sobre bombres masculinidades y relaciones de género en Colombia; y el artículo "El gobierno de la sexualidad juvenil y la gestión de las diferencias"

\section{Renata Pimentel}

Possui bacharelado em Letras (I993), mestrado (200I) e doutorado (2007) em Teoria da Literatura pela Universidade Federal de Pernambuco (UFPE). Atualmente é professora adjunta do Departamento de Letras da Universidade Federal Rural de Pernambuco (UFRPE). Desenvolve estudos relacionados a teoria e crítica literárias, sobretudo nos contextos da literatura brasileira e latino-americana, em especial na narrativa de ficção e na dramaturgia. É líder do Grupo de Estudos Literários Comparados (GELC), cadastrado na base do Conselho Nacional de Desenvolvimento Científico e Tecnológico (CNPq) e certificado pela UFRPE; também é pesquisadora vinculada ao Núcleo Interdisciplinar de Estudos da Linguagem (NIEL).

\section{Viviane Vergueiro}

Mestra em Cultura e Sociedade pelo Programa Multidisciplinar de Pós-Graduação da Universidade Federal da Bahia (UFBA) e ativista transfeminista, integra o grupo Cultura e Sexualidade (CuS - UFBA), além disso, possui graduação em Ciências Econômicas (2006) pela Universidade Estadual de Campinas (Unicamp). 


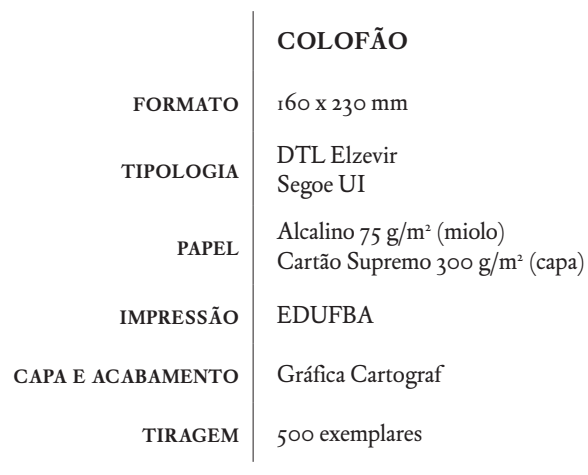

